UNIVERSIDADE DE SÃO PAULO

INSTITUTO DE GEOCIÊNCIAS

\title{
FATORES CONTROLADORES DE SISTEMAS EÓLICOS COSTEIROS CARBONÁTICOS: OS EOLIANITOS QUATERNÁRIOS DO PIAUÍ E OESTE DO CEARÁ
}

\author{
VALENTINA ESPINEL ARIAS \\ Orientador: Prof. Dr. Paulo César Fonseca Giannini \\ DISSERTAÇÃO DE MESTRADO \\ Programa de Pós-Graduação em Geoquímica e Geotectônica
}

São Paulo

2015 
Autorizo a reprodução e divulgação total ou parcial deste trabalho, por qualquer meio convencional ou eletrônico, para fins de estudo e pesquisa, desde que citada a fonte.

Ficha catalográfica preparada pelo Serviço de Biblioteca e Documentação do Instituto de Geociências da Universidade de São Paulo

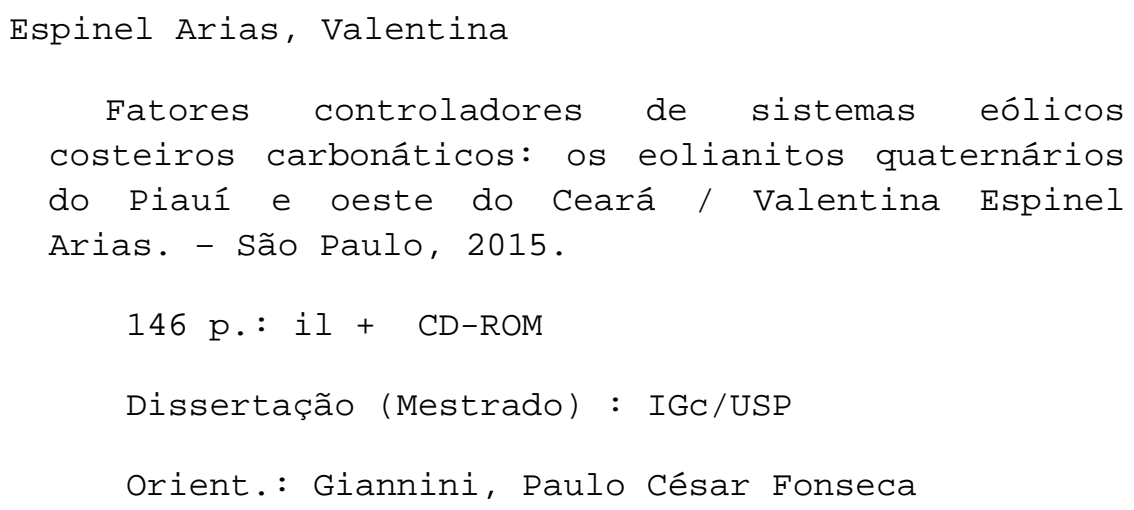

1. Eolianitos 2. Petrografia I. Título 


\section{Sumário}

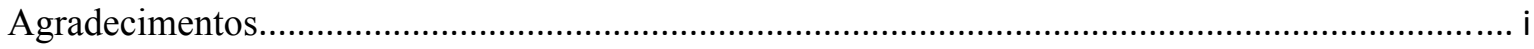

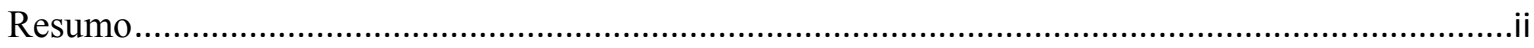

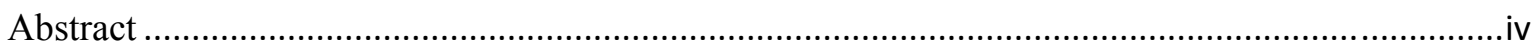

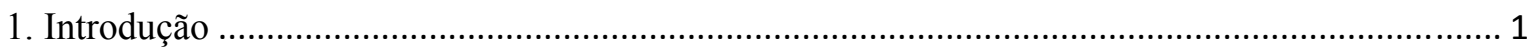

1.1. Delimitação de hipóteses de trabalho e problemas científicos .................................................. 1

1.2. Relevância do estudo de sistemas eólicos carbonáticos .............................................................. 4

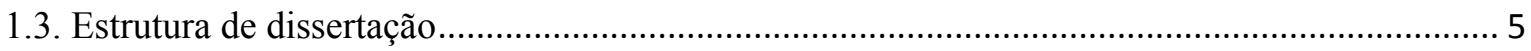

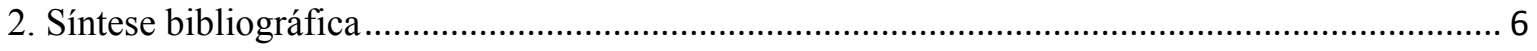

2.1 Fatores controladores de sedimentação eólica …………….................................................... 6

2.2. Controles particulares na formação de eolianitos.................................................................... 7

2.3. Distribuição no tempo dos depósitos eólicos quaternários do Brasil .......................................... 8

2.4. Tipologia de elementos morfológicos eólicos costeiros........................................................ 9

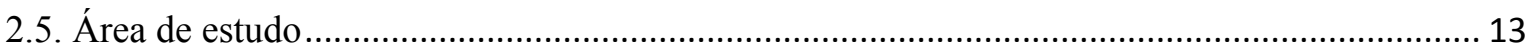

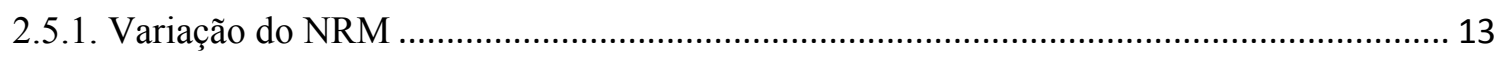

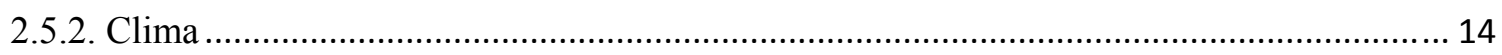

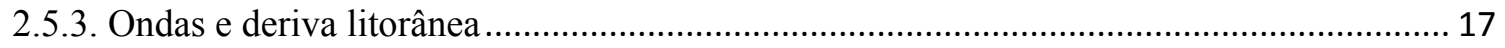

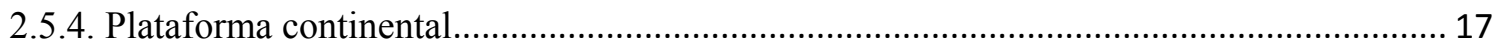

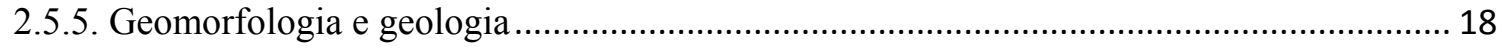

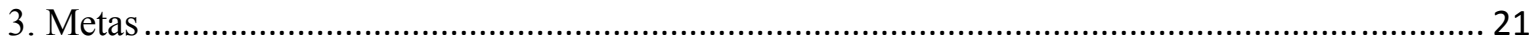

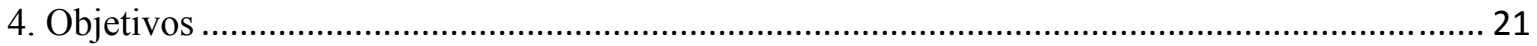

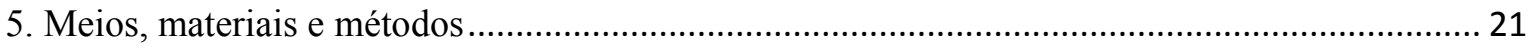

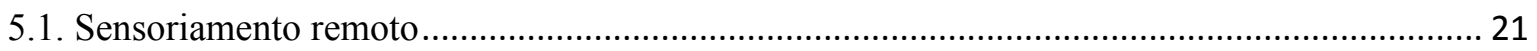

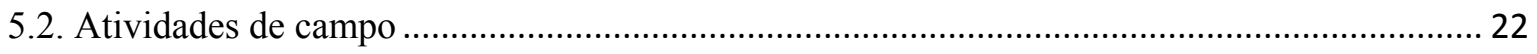

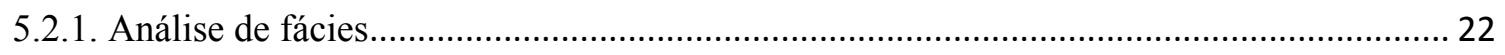

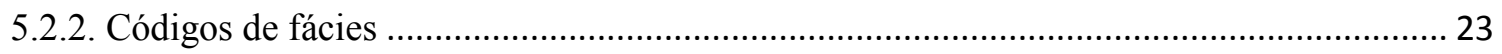

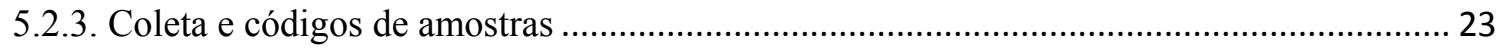

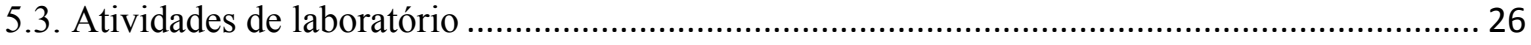

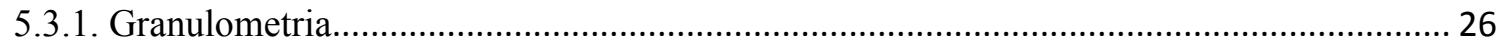

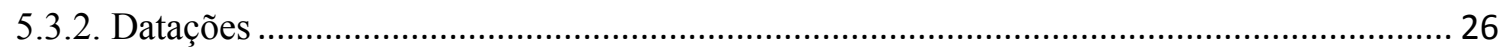

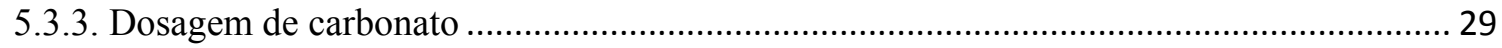

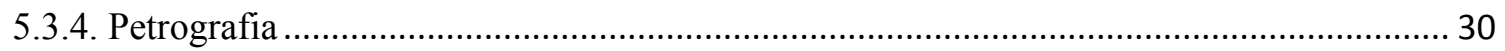

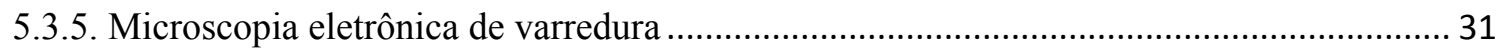




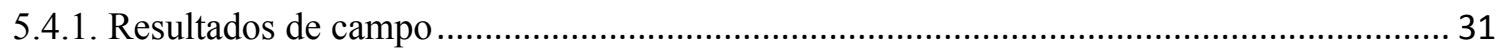

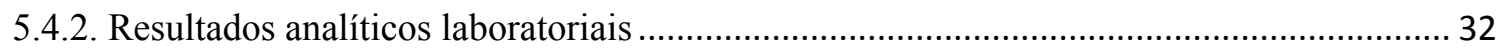

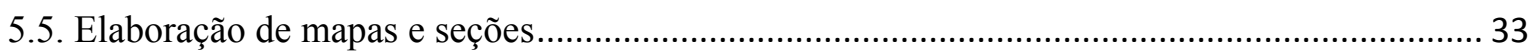

6. Artigo 1: Morfologia, fácies deposicionais e cronologia dos eolianitos quaternários do litoral do

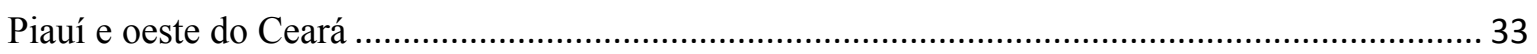

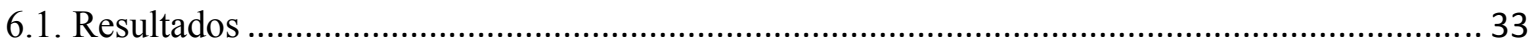

6.1.1. Subdivisão morfológica do sistema eólico costeiro e os cordões de eolianitos ................... 33

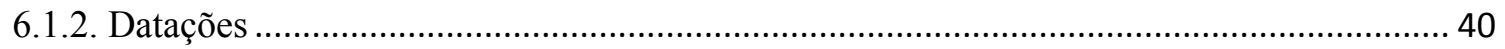

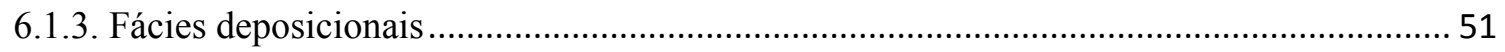

6.1.4. Distribuição espacial de fácies deposicionais e associações de fácies ................................. 55

6.1.5. Distribuição de fácies deposicionais no tempo .................................................................. 71

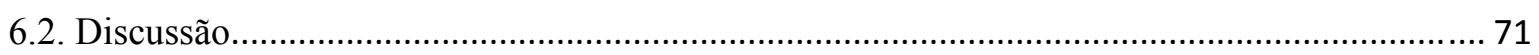

6.2.1. Controles de formação e distribuição espacial dos eolianitos ............................................ 71

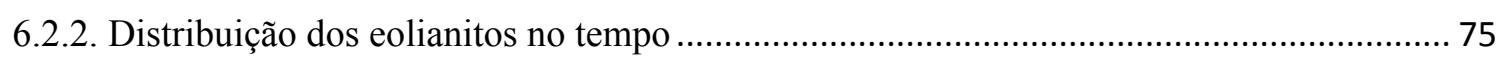

6.2.3. Significado das fácies deposicionais e de sua distribuição no tempo.................................. 77

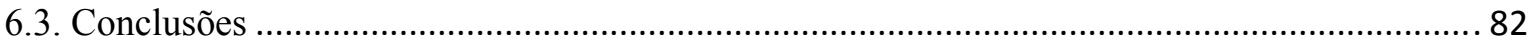

7. Artigo 2 - Sedimentologia e petrografía dos eolianitos holocênicos da costa do Piauí e Ceará... 84

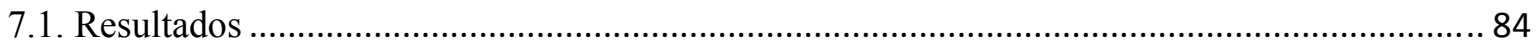

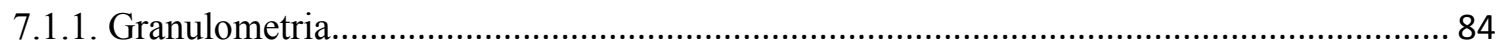

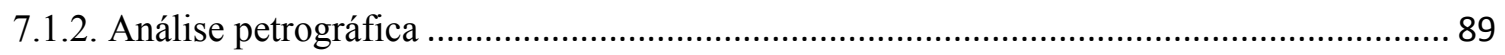

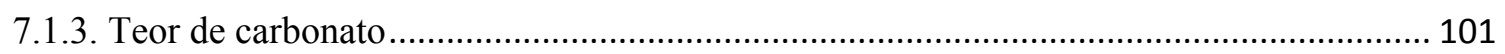

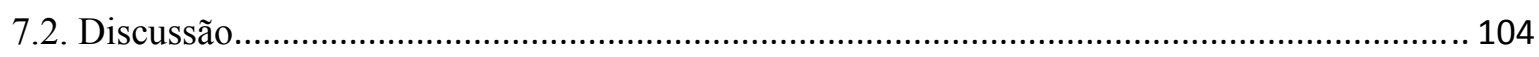

7.2.1. Granulometria dos eolianitos e suas relações com as fácies morfológicas e a distância à

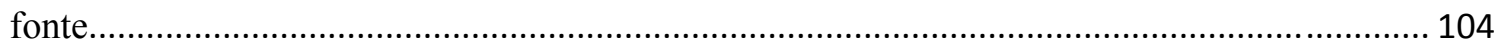

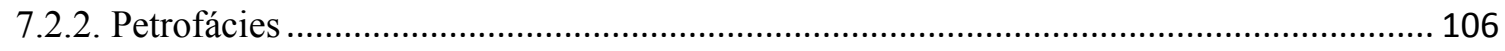

7.2.3. Variação das petrofácies de eolianitos ................................................................................ 113

7.2.4. Características da diagênese dos eolianitos e seus fatores determinantes ........................ 115

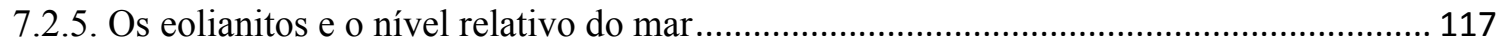

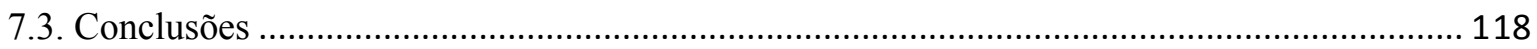

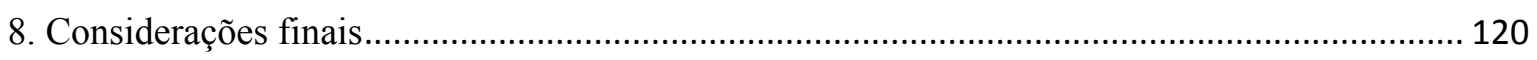

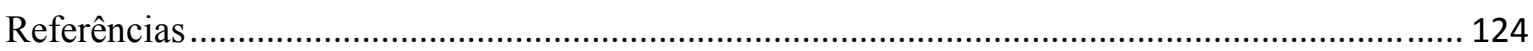




\section{Índice de Figuras}

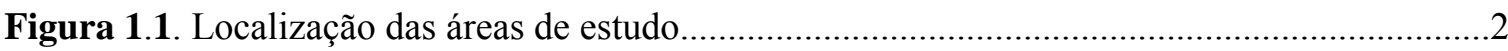

Figura 2.1. Elementos morfológicos de campos de dunas............................................................11

Figura 2.2. Outros Elementos morfológicos de campos de dunas..................................................12

Figura 2.3. As três associações de elementos morfológicos em sistemas eólicos costeiros ativos do Brasil.

Figura 2.4. Localização da Zona de Convergência Intertropical no inverno e no verão austrais.

Figura 2.5. Variação anual da deriva eólica (DEP) nas estações meteorológicas Inmet de:

a.Parnaíba (PI), período 1976-2010; b. Acaraú (CE)..

Figura 2.6. Plataforma continental da área de estudo, com representação dos tipos de sedimentos nos domínios terrígeno e carbonático.

Figura 2.7. Exemplos de lagos associados à obstrução de drenagens costeiras pelo avanço ao interior de dunas e paleodunas, no Piauí.

Figura 2.8. Exemplos de lagos associados à obstrução de drenagens costeiras pelo avanço ao interior de dunas e paleodunas, no Ceará...

Figura 5.1. Localização de amostras no setor norte, no Estado de Piauí. .24

Figura 5.2. Localização de amostras no setor norte, no Estado de Ceará.. .25

Figura 5.3. Localização de amostras no setor centro. .25

Figura 5.4. Localização de amostras no setor sul. .25

Figura 5.5. Esquema de um diagrama em caixa (boxplot).

Figura 6.1. Associações de elementos morfológicos do sistema eólico costeiro ativo, no setor norte.

Figura 6.2. Cordões de eolianitos em formas de cristas descontínuas na área de Itaqui. .35

Figura 6.3. Associações de elementos morfológicos do sistema eólico ativo no setor centro. .37

Figura 6.4. Eolianitos cortados pela linha de costa em erosão na área de Almofala.. .38

Figura 6.5. Associações de elementos morfológicos no sistema eólico ativo do setor sul. 39

Figura 6.6. Idades máximas e mínimas obtidas nos eolianitos do setor norte, no Piauí...................42

Figura 6.7. Idades máximas e mínimas (obtidas nos eolianitos do setor norte, no Ceará.................43

Figura 6.8. Idades máximas e mínimas obtidas nos eolianitos do setor centro.

Figura 6.9. Idades máximas e mínima obtidas nos eolianitos do setor sul.......................................45

Figura 6.10. Gráfico de dispersão das idades de eolianitos em função da distância à costa. . .46

Figura 6.11. Gráfico de dispersão das idades de eolianitos em função da distância à costa, no setor norte. 
Figura 6.12. Gráfico de dispersão das idades de eolianitos em função da distância à costa, nos setores centro e sul agrupados.

Figura 6.13. Gráfico de dispersão das idades de eolianitos em função da distância de W para E.

Figura 6.14. Fácies deposicionais mais comuns presentes nos eolianitos da área de estudo...........52

Figura 6.15. Fácies dos depósitos sedimentares associados aos eolianitos......................................54

Figura 6.16. Distribuição de fácies morfológicas junto à praia de Carnaubinha...............................56

Figura 6.17. Distribuição das fácies morfológicas junto à praia de Maramar....................................57

Figura 6.18. Distribuição das fácies morfológicas junto à praia de Macapá......................................58

Figura 6.19. Distribuição das fácies morfológicas na área de Bitupitá...............................................59

Figura 6.20. Distribuição das fácies morfológicas junto à praia Nova..............................................60

Figura 6.21. Distribuição das fácies morfológicas junto à praia Maceió............................................61

Figura 6.22. Coluna sedimentar correlacionada ao substrato dos eolianitos no ponto EPI45..........63

Figura 6.23. Eolianitos, e suas fácies associadas, observadas nos pontos ECE47 e ECE51 ............64

Figura 6.24. Distribuição das fácies morfológicas e do cordão de eolianito na área de Itarema.

Figura 6.25. Distribuição das fácies morfológicas e do cordão de eolianitos junto à porção sudeste da praia de Almofala.

Figura 6.26. Distribuição das fácies morfológicas e dos corpos de eolianito junto à praia de Imboaca.

Figura 6.27. Distribuição das fácies morfológicas e dos corpos de eolianito junto à praia de Guajiru.

Figura 6.28. Distribuição das fácies morfológicas e dos corpos de eolianito junto à praia de Piriquara, em Paracuru. .70

Figura 6.29. Diagrama em caixa de idades de eolianitos, por fácies deposicional..........................71

Figura 6.30. Tipos de sistemas eólicos costeiros do Brasil.............................................................75

Figura 6.31. Histograma das idades obtidas em eolianitos............................................................

Figura 6.32. Ocorrência de Pomacea sp. no campo de dunas costeiras de Tutoia, MA. A............79

Figura 7.1. Diagrama em caixa para variação do diâmetro médio dos eolianitos.............................85

Figura 7.2. Diagrama em caixa para variação do desvio dos eolianitos............................................86

Figura 7.3. Diagrama em caixa para variação da dos eolianitos......................................................86

Figura 7.4. Diagrama em caixa para variação do diâmetro médio nas três fácies mais comuns dos eolianitos.

Figura 7.5. Diagrama em caixa para variação do desvio padrão nas três fácies mais comuns dos eolianitos. 
Figura 7.6. Diagrama em caixa para variação da assimetria nas três fácies mais comuns dos eolianitos.

Figura 7.7. Aspecto geral do arcabouço dos eolianitos. .89

Figura 7.8. Tipos de bioclastos mais comuns nas lâminas de eolianito. .90

Figura 7.9. Clastos intrabacinais ou bioturbações observados nas lâminas de eolianito. .91

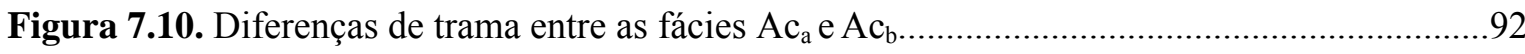

Figura 7.11. Feições características de cimentação microespática anterior à compactação. .93

Figura 7.12. Arranjos de cimento carbonático ligados a tensão superficial ou ascensão ou descenso de fluidos intersticiais.

Figura 7.13. Outros arranjos de cimento carbonático presentes nos eolianitos................................95

Figura 7.14. Mapas de concentração de elementos químicos na lâmina ECE49E...........................96

Figura 7.15. Feições de porosidade, cimentação e compactação em lâminas de eolianito..............97

Figura 7.16. Quartzo arenito da fácies Rg (lâmina ECE49con) ……………………………….....98

Figura 7.17. Componentes presentes nas amostras de beach-rocks, fácies Apb.............................99

Figura 7.18. Arenito com grãos da amostra ECE51PB...............................................................100

Figura 7.19. Quartzoarenito da Formação Barreiras amostra ECE47FB.......................................100

Figura 7.20. Quartzo arenito com gastrópodes (fácies Amg)......................................................101

Figura 7.21. Teor de carbonato determinados por dissolução química de eolianitos.....................102

Figura 7.22. Teor de carbonato determinado por dissolução química de praias e dunas................102

Figura 7.23. Diagramas em caixa comparando as análises de teor de carbonato pela petrografia e por dissolução dos eolianitos.

Figura 7.24. Gráfico de dispersão relacionando a idade com o teor de carbonato dos eolianitos.

Figura 7.25. Fotomicrografías das petrofácies da associação Q1f.................................................107

Figura 7.26. Fotomicrografias das petrofácies da associação Q2f.................................................108

Figura 7.27. Fotomicrografias das petrofácies da associação Q1v................................................109

Figura 7.28. Fotomicrografias das petrofácies da associação Q2v...............................................110

Figura 7.29. Petrofácies dos depósitos associados aos eolianitos..................................................112

Figura 7.30. Mapas do setor norte com a localização das amostras de petrografia e as associações de petrofácies.

Figura 7.31. Mapas dos setores centro e sul com a localização das amostras de petrografia e as associações de petrofácies.

Figura 7.32. Diagrama em caixa para a variação do teor em massa de carbonato. 
Figura 7.33. Diagrama em caixa para a variação de porosidade por associação de petrofácies

Figura 8.1. a. comparação entre índices de Ti-Ca do núcleo marinho 3912 ; b. registro $\delta^{18} \mathrm{O}$ do espeleotema Bt2 na caverna Botuverá, Sul do Brasil c. registro de Ti na Bacia Cariaco; d. registro $\mathrm{RN}$ e e. insolação de fevereiro a $10^{\circ} \mathrm{S}$. Tomado de Cruz et al 2009

Figura 8.2. Média de longo prazo (1979-2000) Centro de Previsão do Clima Mesclado com Analises de precipitação total (em $\mathrm{mm}$ ) para Decembrer-fevereiro (esquerda) e de março a maio (à direita). Tomado de Cruz et al 2009

\section{Índice de Tabelas e Quadros}

Tabela1. Relação de idades das amostras de eolianitos.

Tabela 2. Relação das idades das amostras de depósitos associados aos eolianitos.

Quadro 1. Proposta de correlação entre gerações de campos de dunas de diferentes regiões costeiras do Brasil.

Quadro 2. Definições para feições eólicas costeiras formadas sob influência morfodinâmica da vegetação.

Quadro 3. Definições para feições eólicas costeiras formadas sem influência morfodinâmica significativa da vegetação.

Quadro 4. Siglas adotadas para representar litologías e estruturas sedimentares............................23

Quadro 5. Sumário de descrição de fácies deposicionais em eolianitos

Quadro 6. Sumário de descrição de fácies deposicionais nos depósitos sedimentares associados aos eolianitos. .53

Quadro 7. Interpretação das fácies deposicionais de eolianitos. .78

Quadro 8. Interpretação das fácies deposicionais associadas aos eolianitos, ordenadas da mais antiga para a mais nova.

Quadro 9. Sumário de descrição e interpretação das petrofácies de eolianitos. 107

Quadro 10. Sumário de descrição das petrofácies dos depósitos associados aos eolianitos. 


\section{Agradecimentos}

Antes de agradecer quero dedicar este trabalho as pessoas mais importantes na minha vida, minha família, agradeço a meus pais Germán Espinel e Luz Dary Arias e minhas irmãs Karolina e Cristina, obrigada pelo força, apoio e amor incondicionais. Sempre agradeço à vida pela família tão unida e amorosa que temos; meu amor por vocês é infinito!

Ao meu professor e orientador P.C.F. Giannini quem fez o excelente trabalho de me orientar com tudo, assim como um artesão molda sua escultura, muito obrigada pela paciência, ensinamentos e ser uma pessoa tão correta e bacana, quando comecei o processo para vir no Brasil nunca imaginei que me esperava uma pessoa com tantas qualidades.

Ao meu namorado, companhero e amigo Jairo Queiroz, que sempre me brindou o apoio e força incondicional em todo momento, obrigada por cuidar de mim nas minhas doenças, por cada palavra de encorajamento, por me mostrar as lindas paisagens do Brasil e por aquelas piadas ruims que ainda hoje me fazem rir. Te amo!

Muito obrigada a CAPES pela concessão da bolsa. e ao pessoal do Instituto de Geociências da USP, professores, funcionários, principalmente aos do Labsed, Labpetro e o Legal, administrativos e outros que me ajudaram a cumprir com os meus objetivos.

A meus companheiros eólicos Vinicius, Helena, Fernanda e Renata, obrigada pela ajuda e experiências, com cada um de vocês aprendi muitas coisas da geología e da vida.

Ao pessoal na Colômbia, meus amigos e Professor Carlos A. Guzmán, obrigada pelas informações e consejos.

Também agradeço às pessoas que foram minha família neste periodo, meus "parceros" Cristian e Yohana e a galera colombiana, Veronica, Carlos Mario, Sebastian, Santiago, Andres, Laura, Daniel, Diego y Santiago; muito obrigada a todos pela companhia e fazer me sentir na Colômbia.

Agradeço também a meus amigos dos demais cursos da USP, a galera da FFLCH, ao Sergio, Renan, Ricardo e todos os demais que me ensinaram a ver o Brasil desde o ponto de vista mais social e crítico.

As pessoas que esqueci mencionar podem ter certeza que sou grata a todos, muito obrigada por esta linda experiência e espero que gostem deste trabalho. 


\section{Resumo}

Os campos de dunas ativos e os eolianitos do litoral nordeste brasileiro compreendido entre Luís Correia (PI) e Paracuru (CE) estão localizados na área de influência da Zona de Convergência Intertropical, de onde vêm os ventos alísios efetivos na sua formação. A variação da direção exata com que estes ventos atingem a costa constitui o principal critério para dividir a área de estudo em três setores: norte, centro e sul. Em cada setor, a direção do vento efetivo, conjugada com a orientação da linha de costa, determina o grau de desenvolvimento da planície deflacionária, o qual aumenta com o ângulo entre vento e costa. No setor norte (Luís Correia a Camocim, CE), o rumo de vento efetivo é ENE-WSW e o ângulo entre vento e costa varia de $60^{\circ}$, no Piauí, a $20^{\circ}$, no Ceará, com extensões das planícies deflacionárias de $7,5 \mathrm{~km}$ e $2,5 \mathrm{~km}$, respectivamente; o setor centro (Itarema e Almofala) apresenta rumo do vento E-W e caracteriza-se pela ausência de campos de dunas; o setor sul possui sentido do vento ESE-WNW e ângulo com a linha de costa de $35^{\circ}$, com zona deflacionária de até $3 \mathrm{~km}$ de comprimento. Os eolianitos apresentam-se como cordões descontínuos com 1 a $15 \mathrm{~m}$ de altura, paralelos à direção do vento efetivo, que ocorrem em meio a planície deflacionária e exibem morfologia análoga à dos rastros lineares residuais ativos típicos desta planície. As datações realizadas em grãos de quartzo, pelo método da luminescência (LOE), e em bioclastos ou no cimento calcítico, por ${ }^{14} \mathrm{C}$ AMS, indicam idades de 650 a 5700 anos, mas com cerca de $80 \%$ delas concentradas no intervalo entre 800 e 3200 anos. Os eolianitos mais próximos à linha de costa são mais antigos que os mais distantes, padrão esperado em rastros lineares residuais, os quais são sucessivamente deixados para trás e estabilizados à medida que o campo de dunas migra. $\mathrm{Na}$ análise de fácies deposicionais dos eolianitos, reconheceram-se quartzo calciarenitos com estratificações cruzadas de alto e baixo ângulo e com ou sem rizoconcreções; a elevada concentração de grossos e o padrão de distribuição de azimutes de mergulho de estratificações cruzadas, o qual é predominantemente bimodal divergente, tendo a direção do vento efetivo e do alongamento das cristas de eolianitos como bissetriz entre as duas modas, reforça a hipótese de associação com rastros lineares residuais. A concentração de eolianitos nesta área do Nordeste brasileiro está ligada à constituição da plataforma continental interna adjacente, a qual é rica em algas vermelhas ramificantes; no entanto, o teor de carbonatos nos eolianitos (10 -25\%) é baixo, comparado com o registrado na plataforma submersa abaixo da isóbata de $10 \mathrm{~m}$ (50\% ou mais), e similar ao do sistema praia-duna atual e da plataforma interna rasa, o que leva a interpretar área fonte imediata na praia. A análise petrográfica permitiu reconhecer quatro petrofácies, todas dominadas por quartzo (Q) no arcabouço. Elas foram diferenciadas a partir do número de modas granulométricas (uni ou bimodal $=1$ ou 2 ) e das tramas e texturas do cimento carbonático, as quais indicam diagênese dominada por processos meteóricos vadosos (petrofácies Q1v e Q2v), estes mais comuns, ou com influência de processos meteóricos freáticos (Q1f e Q2f). $\mathrm{O}$ conjunto de resultados obtidos, confrontado com reconstituições climáticas para o Holoceno do Nordeste do Brasil, permite interpretar que o paleoclima quente, ventoso e pouco úmido, favorável à formação dos eolianitos, estabeleceu-se na região nos últimos 4000 a 5000 anos. Momentos de estabilização das dunas e colonização por vegetação, evidenciados nas fácies de cruzadas de ângulo baixo com rizoconcreções, e mudanças no 
nível freático, sugeridas pela alternância entre texturas de cimentação vadosa e freática, podem ter tido origem tanto autogênica, ligada ao distanciamento progressivo entre rastros lineares e fonte praial, quanto alogênica, ligada a flutuações de precipitação e/ou intensidade dos ventos.

Palavras chave: Paleodunas calcárias, planície deflacionária, rastros lineares residuais, datações, petrofácies, paleoclima holocênico 


\section{Abstract}

The active dune fields and the eolianites between Luís Correa (Piauí State) and Pararucu (Ceará State), Northeastern Brazil, are located in the area of Intertropical Convergence Zone influence, from where come the trade winds responsible by their formation. The variation of the direction in which these winds reach the coast is the main criterion to divide the study area into three sectors: north, center and south. In each sector, the direction of the effective wind, combined with the coastline orientation, determines the deflation plain development, which increases with the angle between wind and coast. In the northern sector (Luís Correia to Camocim), the wind direction is from ENE and the angle between wind and coast ranges from $60^{\circ}$ in Piauí to $20^{\circ}$ in Ceará, with deflation plains $7.5 \mathrm{~km}$ and $2.5 \mathrm{~km}$ long, respectively; the central sector (Itarema and Almofala) presents wind from $\mathrm{E}$ and is characterized by the absence of dune fields; the southern sector winds direction is from ESE and the angle with the coastline is $35^{\circ}$, with deflation zone up to $3 \mathrm{~km}$ long. The eolianites appear as discontinuous ridges with up to $15 \mathrm{~m}$ high, parallel to the direction of the effective wind. They occur in the deflation plain and exhibit similar morphology to active trailing ridges. The quartz grains dating by luminescence (OSL) and bioclasts or calcite cement dating by ${ }^{14} \mathrm{C}$ AMS indicate ages between 650 to 5700 years, but about $80 \%$ of them are concentrated in the range between 800 and 3200 years. The eolianites nearest to the coastline are older than the farthest ones, a pattern expected in trailing ridges, which are successively left behind and stabilized as the dune field migrates. The eolianites depositional facies include quartz calcarenites with high or low angle cross stratification and with or without rizoconcrections. Field properties that reinforces the hypothesis that eolianites are trailing ridges deposits include the high concentration of coarse grains, the divergent bimodal pattern of cross stratification dip direction distribution, and the lengthening of eolianite crests parallel to the effective wind direction and to the bisectrix between the two dip direction modes. The concentration of Brazilian eolianites in this area is related to the adjacent inner continental shelf constitution, which is rich in branching red algae. However, the eolianites carbonate content $(10-25 \%)$ is low if compared to the record in the submerged shelf below the $10 \mathrm{~m}$ isobath ( $50 \%$ or more), and similar to the current beach - foredune system and to the shallow inner shelf, which leads to conclude that the immediate source area is on the beach. The petrographic analysis allowed us to recognize four petrofacies, all of them dominated by quartz (Q) in the framework. They were differentiated by the number of particle size modes (uni or bimodal $=1$ or 2 ) and by carbonate cement petrofabric and textures, which indicate diagenesis dominated by vadose meteoric processes (petrofacies Q1v and Q2v), with subordinate influence by phreatic meteoric processes (Q1f and Q2f). The set of results obtained, faced to climate reconstructions for the Holocene in the Northeastern Brazil, allows interpreting that the warm paleoclimate, windy and little wet, favorable to eolianites formation, has settled in this region in the past 4000 to 5000 years. Moments of dune stabilization and vegetation colonization, evidenced in facies of low angle cross stratification with rizoconcrections, and changes in the water table, suggested by the interchange between vadose and phreatic cement textures, may have origin either autogenic, related to progressive detachment between trailing ridges and beach source, or allogenic, related to precipitation and/or winds intensity fluctuations.

Keywords: carbonate paleodunes, deflation plain, trailing ridges, dating, petrofacies, Holocene paleoclimate 


\section{Introdução}

\subsection{Delimitação de hipóteses de trabalho e problemas científicos}

Reconstruções paleoclimáticas no Quaternário em costas continentais ou em ilhas oceânicas específicas podem contribuir para a compreensão do cenário paleoambiental em escala global. Isto se baseia no fato de que mudanças climáticas, muitas vezes opostas, ocorrem em diferentes regiões de modo sincrônico, determinadas pelo deslocamento dos grandes elementos de circulação atmosférica, como a Zona de Convergência Intertropical (ZCIT) e a Zona de Convergência do Atlântico Sul (ZCAS), ambas faixas de nebulosidade e umidade (Tsoar et al 2009) com controle sobre a precipitação e a direção ou intensidade dos ventos e, por decorrência, sobre a formação e estabilização de depósitos eólicos. Desse modo, estudos regionais sobre deposição pelo vento, quando devidamente situados em relação a eles, ganham significado na interpretação de mudanças climáticas globais.

O litoral do Piauí e Ceará, compreendido entre Luís Correia (PI) e Paracuru (CE), que é a área objeto deste estudo (Figura 1.1), situa-se próximo da atual posição média extremo sul da ZCIT (ou posição de verão austral), o que significa que, no restante do ano, fica praticamente fora da faixa de atuação desta zona de nebulosidade e precipitação. Possui unidades geológicas e geomorfológicas quaternárias formadas pelo vento, como campos de dunas livres ativos e eolianitos, estes geralmente na forma de remanescentes de erosão. O termo eolianito, introduzido por Sayles (1931) no Quaternário das Bermudas, designa depósitos eólicos cimentados por carbonato, geralmente calcita em condições meteóricas, formados em áreas costeiras com acumulações de areias biogênicas (Fairbridge \& Johnson 1978, Pye 1983, Tucker \& Wright 1990). Em vista desta origem, os eolianitos refletem controle exercido pelo clima e pelo nível relativo do mar (NRM) na sua formação (Brooke 2001). Este controle manifesta-se de dois modos: no acúmulo de material carbonático biogênico, incoeso; e na exposição deste material à ação de ventos com competência para transportá-los. Relacionado a este controle, o primeiro problema científico desta dissertação é uma questão de proveniência: como se explica, na costa do Piaú e Ceará, a disponibilidade de material carbonático em escala regional (de sistema costa-plataforma)? 


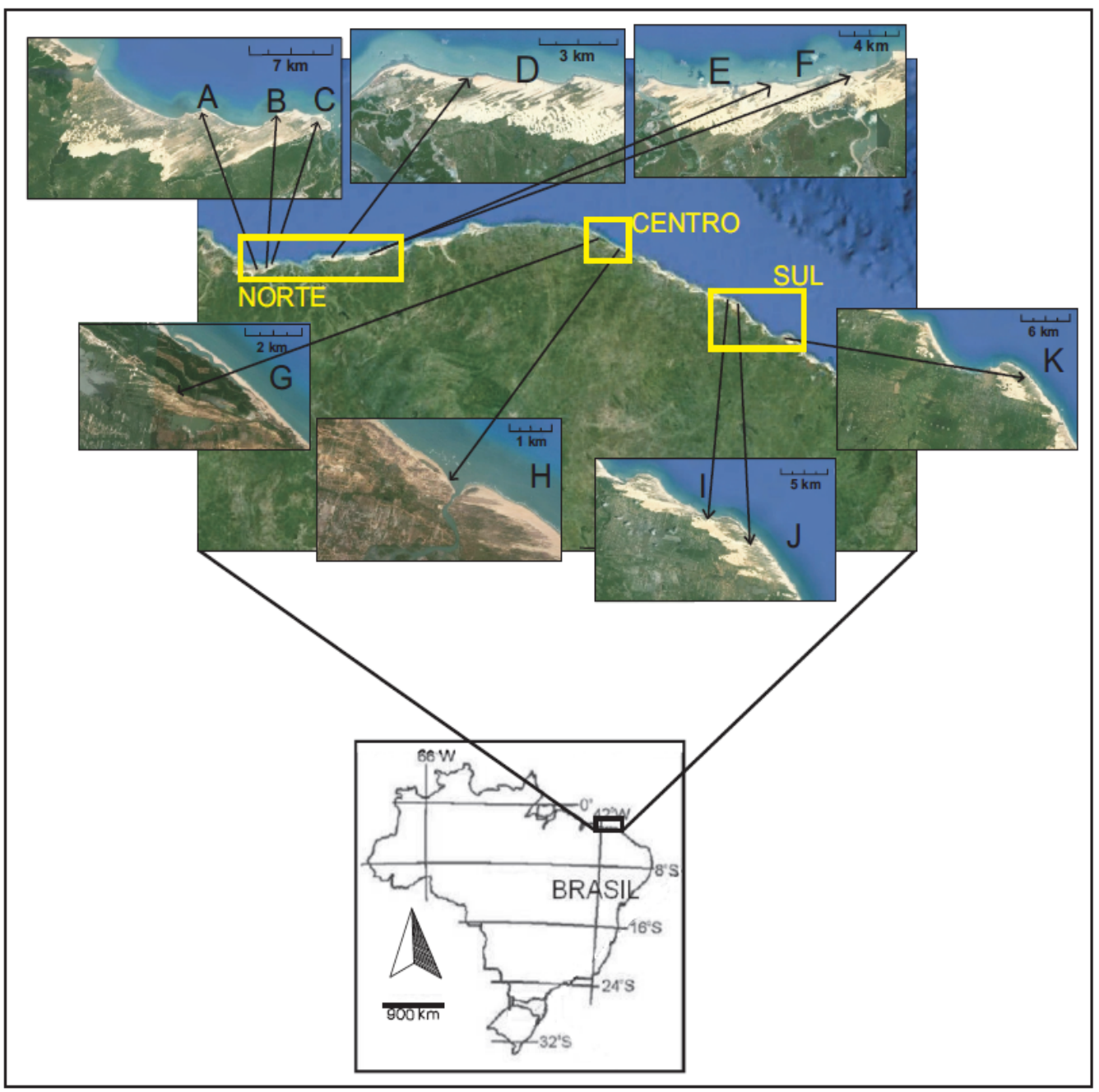

Figura 1.1. Localização das áreas de estudo, de $W$ para E: A. Itaqui (Luís Correia). B. Carnaubinha-Maramar (Luís Correia). C. Macapá (Luís Correia). D. Bitupitá (Barroquinha). E. Praia Nova (Camocim). F. Maceió (Camocim). G. Itarema (Itarema). H. Almofala (Itarema). I. Imboaca (Trairi). J. Guajiru (Trairi); e K. Piriquara (Paracuru). A a C ficam no Estado do Piauí, e D a $\mathrm{K}$, no Ceará. Os nomes entre parêntesis correspondem aos municípios. Imagens retiradas do software Google Earth.

Os eolianitos brasileiros são às vezes constituídos por areia média a grossa (Baptista 2010, Angulo et al. 2013), tamanho pouco usual para fácies eólicas francamente deposicionais, o que faz pensar, como hipótese de trabalho, na possibilidade de se tratar de fácies residuais de deflação, onde as carapaças carbonáticas, comparativamente mais grossas e pesadas que os grãos quartzo-feldspáticos, ficariam melhor representadas. De modo a testar esta hipótese, a segunda questão-problema desta dissertação pode ser enunciada como: que fatores controlam a disponibilidade de material carbonático em escala local (de campo de dunas)?; e o quanto e de que modo esta disponibilidade determina a formação de eolianitos? Responder a estas duas questões deve ajudar a separar controles locais de regionais na distribuição dos eolianitos do Nordeste e permitir compreender, respectivamente, os seus possíveis significados faciológicos e paleoclimáticos.

O aumento de aporte carbonático na plataforma e nos campos de dunas ocorre em detrimento do aporte terrígeno. Desse modo, não se pode tratar adequadamente da origem 
e distribuição tempo-espacial dos eolianitos, sem levar em consideração a origem e distribuição dos depósitos análogos de constituição terrígena. Dentre estes últimos, pelo menos quatro gerações quaternárias têm sido admitidas em áreas da costa continental brasileira com campos de dunas livres (Bittencourt et al. 1982, Dominguez et al. 1996, Barbosa et al. 1986, Barbosa 1997, Giannini et al. 2005), inclusive em trabalhos de datação sistemática por termoluminescência (TL) e luminescência opticamente estimulada (LOE) realizados no Maranhão (Maia et al. 2011, Guedes et al. 2011), Rio Grande do Norte (Barreto et al. 2004, Maia et al. 2011), Paraíba (Barreto et al. 2002) e Santa Catarina (Sawakuchi 2003, Giannini et al. 2007, Mendes 2012, Andrade 2012, Mendes et al. 2015). A primeira geração seria anterior ao Último Máximo Glacial (UMG); a segunda, posterior ao UMG e anterior a contemporânea à máxima inundação holocênica; e as duas últimas, uma ativa e outra inativa, são posteriores a esta máxima inundação (Giannini 2007, Giannini et al. 2007). Os dados disponíveis para os depósitos eólicos costeiros do Ceará (Maia 1998, Claudino Sales \& Peulvast 2001, Claudino Sales 2002, Carvalho 2003, Carvalho et al. 2008) não contrariam este modelo geral de quatro gerações, ainda que com poucas datações (Maia et al. 2011). Os eolianitos teriam sido depositados juntamente com a terceira geração, em vista das idades ${ }^{14} \mathrm{C}$ entre $1780 \pm 50$ e $1320 \pm 50$ anos AP obtidas por Castro \& Ramos (2006), nas quais, no entanto, não se especificou o material datado (se bioclasto ou cimento). No Piauí, não se dispunham de dados geocronológicos até o presente estudo.

O modelo mencionado de distribuição de idades de paleodunas costeiras terrígenas em quatro gerações enfatiza o controle do comportamento do NRM e da linha de costa. Porém, fatores ligados ao clima local ou regional, como por exemplo, precipitação e intensidade dos ventos, podem ter sido tão ou mais importantes, seja no desencadeamento seja na estabilização de dunas costeiras. Para as paleodunas do Holoceno, por exemplo, todas formadas sob um mesmo contexto de nível do mar alto, resultados de datação LOE na Ilha Comprida (Sawakuchi et al. 2008) e no centro-norte de Santa Catarina (Mendes 2012, Andrade 2012, Zular et al. 2012, Mendes et al. 2015) apontam nessa direção. Mas o exemplo mais claro é o do Maranhão, onde a geração de maior representatividade em área possui idades LOE concentradas em torno de $17 \mathrm{ka}$ AP (Maia et al. 2011, Guedes 2012), época coincidente com o último evento paleoclimático Heinrich (H1). Esta coincidência tem levado à hipótese, aventada por Guedes et al. (2011), de que sua estabilização tenha sido determinada pela umidificação do clima que teria ocorrido no território brasileiro, segundo Cruz et al. (2005, 2009), por ocasião do evento H1. Aceita esta hipótese, a estabilização das dunas terrígenas ocorreria em resposta ao aumento de umidade e coesão da areia e, por decorrência, da cobertura vegetal. A cimentação destas dunas viria em seguida, numa escala de séculos a milênios, como conseqüência da infiltração de matéria orgânica derivada da cobertura vegetal.

Este modelo, porém, não necessariamente se aplica ao caso dos eolianitos, já que aí a cimentação precoce por carbonato, determinada por outros fatores além da umidade elevada e da vegetação, pode ser um mecanismo adicional da estabilização (Brooke 2001). Não se sabe ainda, por exemplo, se a cimentação dos eolianitos brasileiros é favorecida por fases secas, de freático baixo, à semelhança de calcretes, ou por fases úmidas, como em muitas dunas terrígenas tropicais; e este é um tema por ser investigado por duas vias: 
datações, confrontadas com reconstituições paleoclimáticas para o Nordeste do Brasil disponíveis na literatura; e análise de fácies, microfácies e petrofácies. Seja como for, a cimentação precoce aumenta a resistência dos eolianitos recém-formados aos eventos erosivos superimpostos e eleva assim o seu potencial de preservação ao longo do tempo. Em parte por esta razão, eolianitos quaternários podem apresentar estratigrafia mais completa e complexa que os sítios de sedimentação eólica terrígena, como bem exemplificado na costa oeste da Austrália (Hearty e O'Leary 2008).

Assim, uma terceira questão-problema desta dissertação pode ser traduzida como: o desenvolvimento de dunas carbonáticas ocorre em momentos e/ou locais distintos daqueles favoráveis ao desenvolvimento de dunas de areia terrígena? Quais as semelhanças e diferenças na maneira como nível do mar, linha de costa, clima e dinâmica autogênica do sistema (distribuição de fácies, por exemplo) controlam a iniciação e a estabilização destes dois tipos de dunas?

Frente a estas questões e estratégias de abordagem, a proposta desta dissertação de Mestrado é estabelecer um arcabouço estratigráfico, balizado por datações absolutas, para os eolianitos da região costeira continental brasileira atravessada pela ZCIT, por meio de um estudo sistemático integrado de geomorfologia, fácies e petrofácies. Espera-se contribuir para o refinamento ou a integração de informações sobre os potenciais fatores controladores do suprimento eólico, com destaque para clima e NRM, e testar, corrigir e ampliar os modelos conceituais de iniciação e estabilização de campos de dunas costeiros previamente sugeridos para o território brasileiro (Sawakuchi 2006, Giannini et al. 2007, Giannini 2007, Giannini et al. 2011, 2014, Guedes 2012), de modo a contemplar as especificidades dos depósitos carbonáticos.As principais motivações da pesquisa são, portanto, determinar as idades máxima e mínima dos eolianitos do Piauí e Ceará com os métodos ${ }^{14} \mathrm{C}$ e LOE e tentar decifrar os fatores controladores de sua formação e estabilização e as suas possíveis implicações quanto à posição da ZCIT, da linha de costa e do NRM durante o Holoceno.

\subsection{Relevância do estudo de sistemas eólicos carbonáticos}

Pelo menos dois aspectos justificam a realização de estudos sobre os sistemas eólicos carbonáticos no Quaternário do Brasil. O primeiro é o uso destes sistemas como fonte de informação para a elaboração e validação de modelos climáticos de escala secular a milenar. A esse respeito, é ilustrativo lembrar que a grande maioria das variáveis que supostamente controlam a morfodinâmica de dunas costeiras, tanto terrígenas quanto carbonáticas, está ligada ao clima, de modo seja direto (ventos, umidade e ondulações de swell), seja indireto (NRM, nível freático). Mas a influência do clima ressalta-se ainda mais no caso de eolianitos, cujas areias bioclásticas pressupõem a presença e/ou exposição de plataformas carbonáticas biogênicas, estas fortemente controladas por fatores ambientais de fundo paleoclimático tais como turbidez, temperatura da água e proveniência das ondas. O segundo aspecto é a escassez de estudos morfológicos, petrográficos e cronológicos em eolianitos no Brasil e o interesse acadêmico em estender o crescente 
conhecimento sobre a distribuição de feições eólicas costeiras (Hesp 2000, Giannini et al. 2005, Martinho et al. 2006, Giannini et al. 2011), e seu registro sedimentar, ao caso das dunas carbonáticas.

\subsection{Estrutura de dissertação}

Uma das metas de qualquer trabalho de investigação cientifica é a publicação, motivo pelo qual se optou por elaborar esta dissertação na forma de dois artigos diferentes, a serem submetidos a revistas científicas após a defesa do mestrado, com as correções oriundas das observações e críticas da banca examinadora.

Com o propósito de evitar repetições e facilitar a leitura do volume, os tópicos "Introdução", "Síntese Bibliográfica", "Metas", "Objetivos" e "Materiais e Métodos" são comuns aos dois artigos, sendo que a separação entre eles só ocorre nos respectivos itens de "Resultados", "Discussões" e "Conclusões". Após a apresentação destes itens, a dissertação encerra-se com um tópico de "Considerações Finais", no qual se procura integrar as conclusões dos dois artigos. Todas as citações bibliográficas feitas nesta dissertação, inclusive nos artigos, encontram-se relacionadas no último item, "Referências".

A divisão do conteúdo dos dois artigos foi feita de maneira lógica, de modo que um se ligue ao outro, em enfoque analítico (do todo para as partes), o que é também coerente com a ordem de desenvolvimento do trabalho. Assim, o Artigo1 foi elaborado como um estudo macro das regiões visitadas, envolvendo o sensoriamento remoto, a análise de feições morfológicas ativas e sua correlação com as fácies deposicionais dos eolianitos. Inclui ainda o exame da distribuição das datações no espaço, em relação à geografia, distância à costa e contexto de fácies, e no tempo. Esse artigo versa portanto, em essência, sobre as fácies dos campos de dunas ativos e inativos, e suas interrelações, e sobre a cronologia dos eolianitos.

O Artigo 2 baseia-se em análises mais detalhadas, utilizando os dados de laboratório e conjugando-os com as datações para interpretar a formação dos eolianitos estudados no contexto das mudanças paleoclimáticas, de NRM e de linha de costa. Nestes aspectos, a proposta do artigo é relacionar as quantidades e tipos de bioclastos com a importância relativa das áreas fontes de terrígenos (emersas) e de carbonatos (na plataforma continental submersa); e as tramas de cimento carbonático com a posição relativa do nível freático. Incluíram-se dados de granulometria, petrografía, teor de carbonatos e datações. 


\section{Síntese bibliográfica}

\subsection{Fatores controladores de sedimentação eólica}

Kocurek \& Havholm (1993) apresentaram um modelo de descrição de sistemas deposicionais eólicos contemplando a questão do saldo ou balanço sedimentar e do espaço para estocagem deste saldo, de acordo com o enfoque sistêmico e com o arcabouço conceitual da estratigrafia de seqüências. $O$ saldo, no caso, refere-se à diferença entre entradas e saídas de sedimentos eólicos, ou influxo e efluxo, respectivamente. $\mathrm{O}$ influxo pode ser entendido como a deriva eólica efetiva, isto é, combinação de deriva eólica potencial com suprimento sedimentar disponível para o transporte pelo vento (Giannini et al. 2005, 2008). O espaço de estocagem é determinado pela posição do nível freático relativa à superfície deposicional, controlada basicamente pelo clima e pela taxa de subsidência, os quais, nos casos costeiros, agem combinadamente através do NRM.

Em escala macroambiental, o saldo sedimentar eólico depende do aporte primário, isto é, da disponibilidade de sedimentos no sistema costeiro que atua como fonte, controlado por variáveis imediatas (locais e de curto prazo) e variáveis mediatas (regionais e de longo prazo). Entre as variáveis imediatas que favorecem o aporte primário de modo favorável à formação de sistemas eólicos, destacam-se a chegada de sedimentos no sistema fonte (incluindo efeito da deriva litorânea longitudinal, dependente da energia e orientação das frentes de ondulações), o grau de exposição desses sedimentos, em estado incoeso, à ação do vento onshore (ligado, no caso costeiro, ao grau de dissipatividade da praia) e a escassez de vegetação ligada a fatores climáticos, como ventosidade e falta de chuvas (Giannini 2007).

As variáveis mediatas que controlam o aporte primário e seu potencial de transferência para o sistema eólico costeiro quaternário abrangem clima, condições antecedentes, dimensões do sistema eólico, tempo de interação do sistema, aporte sedimentar e geometria da área fonte (Giannini 2007, Ewing \& Kocurek 2010). Elas são determinadas por controles geológicos, climáticos e oceanográficos que são, muitas vezes, inter-relacionados entre si. Assim, de forma mais generalista, podem-se destacar três controles principais: condições climáticas (ventos, precipitação e tempestuosidade), NRM e contexto fisiográfico regional da área de fornecimento e acumulação (Goldsmith 1978, Carter 1988, Pye \& Tsoar 1990, Lancaster 1995, Sawakuchi 2006, Giannini 2007).

A formação de sistemas eólicos costeiros é em tese favorecida em tratos de sistema de mar alto (Cooper 1958, Roy \& Thom 1981, Thom et al. 1981, Pye \& Bowman 1984, Giannini 1993, Giannini \& Santos 1994, Giannini et al. 2001b, Sawakuchi 2003, Lees 2006, Giannini et al. 2007), haja visto o aumento de sedimentos em circulação no prisma costeiro, sob linha de costa pouco variável. Apesar disso, momentos de NRM baixo, sob linha de costa estável, não somente são também favoráveis à formação como propícios à preservação destes depósitos, visto que são seguidos por elevação rápida do NRM e do nível de base de erosão (Mendes 2012, Guedes 2012, Mendes et al. 2015). Além disso, a aparente maior representatividade de sistemas eólicos costeiros de mar alto seria, em parte, 
decorrente de um viés de observação, isto é, o fato de estarmos atualmente numa fase de mar alto (Mendes et al. 2015).

Quanto à fisiografia, a formação de sistemas eólicos costeiros é favorecida em plataformas de baixo declive (menor que $0,8^{\circ}$, aproximadamente), desde que acima do ângulo mínimo necessário para o transporte eficiente de areia pelas ondulações rumo à zona intermarés (em torno de $0,1^{\circ}$, segundo Roy et al. 1994).

\subsection{Controles particulares na formação de eolianitos}

No caso específico dos eolianitos, os fatores de formação são em tese os mesmos de dunas costeiras terrígenas, porém com uma particularidade fundamental, que é a dependência de aporte biogênico carbonático. Este aporte propicia-se pela presença prévia ou contemporânea de plataformas com baixo suprimento terrígeno, favorecida sob clima quente e relativamente seco (McKee \& Ward 1983).

Em termos de distribuição espacial em escala global, a concentração de eolianitos na faixa de média latitude do hemisfério sul estaria ligada à conjunção de baixo aporte terrígeno com clima quente e pouco úmido (Brooke 2001). E o suposto aumento na formação de eolianitos no Quaternário pode ser vinculado ao aparecimento de clima mais seco nessas regiões nesse período. O Sudeste do Brasil constituiria grande exceção à regra de eolianitos em média latitude, dada a presença da Zona de Convergência do Atlântico Sul (ZCAS), o que acaba por determinar clima anomalamente úmido nesta região. Desse modo, é nas áreas de baixa latitude da Região Nordeste, fora da influência da ZCAS e às margens da ZCIT, que se concentram as ocorrências de eolianitos do país.

Variações menores de temperatura, limpidez e salinidade das águas controlam o tipo de sedimento carbonático na plataforma (McKee\& Ward 1983), classificado por James (1997) em duas associações: Photozoa e Heterozoa. A associação Photozoa é formada por organismos bentônicos fotossintetizantes, como clorófitas e rodófitas, além de corais, ooides e peloides. A Heterozoa caracteriza-se por grande diversidade de organismos não recifais, com destaque para moluscos e foraminíferos. Brooke (2001) aventou a hipótese de que a distribuição geográfica global dos eolianitos possui relação estreita com a distribuição da Associação Heterozoa.

Nos eolianitos do Brasil, entretanto, a representatividade destas duas associações ainda não está devidamente quantificada. Nos da costa nordestina continental, Castro et al. (1998) detectaram a presença de testas de foraminíferos bentônicos (das classes Miliolida e Rotalida). Nos de Fernando de Noronha, Santos (2002) e Valença et al. (2005) detectaram predomínio de algas vermelhas, associadas a foraminíferos, mesmos organismos encontrados por Angulo et al. (2013). Estes últimos autores vincularam os eolianitos do Holoceno da ilha ao aumento na formação de recifes de corais, favorecido pela criação de espaço de acomodação sedimentar via transgressão marinha. 


\subsection{Distribuição no tempo dos depósitos eólicos quaternários do Brasil}

O uso de critérios estratigráficos, geomorfológicos e geocronológicos tem permitido o reconhecimento de pelo menos quatro gerações de areias eólicas quaternárias em quatro diferentes áreas costeiras do Brasil com campos de dunas livres: no Ceará; no Rio Grande do Norte e Paraíba; no trecho que vai do Sergipe ao norte da Bahia; e no centro-sul de Santa Catarina (Jaguaruna-Imbituba). A comparação entre as idades inferidas ou determinadas para estas gerações em cada uma dessas quatro áreas permite o traçado de correlações entre elas, balizadas por episódios transgressivos e/ou de variação de NRM, de extensão inter-regional (Quadro 1).

A geração de dunas mais antiga (D5 de Claudino Sales 2002, no Ceará; tênues ou dissipadas de Barreto et al. 2004, no Rio Grande do Norte; Qe1 de Bittencourt et al.1982 e Dominguez et al. 1996, nos estados de Sergipe e Bahia; e geração1 ou G1 de Giannini 1993 e Giannini et al. 2007, no centro-sul de Santa Catarina) é seguramente anterior ao máximo transgressivo do Holoceno e tida também, pelo menos junto à foz do rio São Francisco (SE) e em Santa Catarina, como anterior ou aproximadamente contemporânea ao máximo NRM de 120 ka AP. A segunda geração (D4, tênues ou nítidas, Qe2, G2) apresenta-se como anterior ou aproximadamente contemporânea à máxima inundação ligada ao NRM mais alto do Holoceno. A terceira geração (D3, nítidas, Qe3 de Barbosa 1997, G3) corresponde as dunas inativas posteriores a esta máxima inundação. E a última geração (D1, Qe4, G4) compreende as dunas ativas, com iniciação estimada em poucos séculos.

Quadro 1. Proposta de correlação entre gerações de campos de dunas de diferentes regiões costeiras do Brasil. No Rio Grande do Norte, Paraíba, Santa Catarina e Maranhão, dispõe-se de datações por luminescência ( ). Modificado de Giannini et al. (2007).

\begin{tabular}{|c|c|c|c|c|c|}
\hline Estadoe Região & \multicolumn{5}{|c|}{ GERAÇÃO EÓLICA E RESPECTIVA IDADE INFERIDA OU MEDIDA POR TL /LOE ( ${ }^{\mathrm{x}}$ ) } \\
\hline $\begin{array}{c}\text { Ceará } \\
\text { (Claudino Sales 2002) }\end{array}$ & $\begin{array}{l}\text { D5: anterior à } \\
\text { transgressão } \\
\text { holocênica }\end{array}$ & $\begin{array}{l}\text { D4: contemporânea à } \\
\text { transgressão holocênica }\end{array}$ & $\begin{array}{l}\text { D3: Holoceno médio a } \\
\qquad 1,2 \mathrm{ka}\end{array}$ & $\begin{array}{c}\text { D2: ativa, } \\
\text { iniciada entre } \\
1,2 \text { e } 0,3 \mathrm{ka}\end{array}$ & $\begin{array}{c}\text { D1: ativa, } \\
\text { iniciada após } \\
0,3 \mathrm{ka} \\
\end{array}$ \\
\hline $\begin{array}{c}\text { Maranhão } \\
\text { (Guedes 2012) }\end{array}$ & $\begin{array}{c}\mathrm{G} 0: 258,9+/-24,6^{x} \mathrm{ka} \\
\mathrm{G} 1: 88,0+/-8,6^{\mathrm{x}} \mathrm{ka}\end{array}$ & $\begin{array}{l}\text { G2: anterior à máxima } \\
\text { inundação do } \\
\text { Holoceno27,2-10,4 }\end{array}$ & $\begin{array}{l}\text { Depósitos eólicos } \\
\text { recentes }\end{array}$ & & \\
\hline $\begin{array}{l}\text { Rio Grande do Norte } \\
\text { (Barreto et al. 2004) }\end{array}$ & $\begin{array}{l}\text { Tênuesoudissipadas: } \\
149 \mathrm{ka}\end{array}$ & $\begin{array}{c}\text { Tênues ou nítidas: } \\
\text { 10,8-9,1 ka e } 6,5-5,6 \\
\text { ka } \\
\end{array}$ & Nítidas: $3,5-2,5$ ka AP & 10,5 & \\
\hline $\begin{array}{c}\text { Paraíba } \\
\text { Camaratuba-Traição } \\
\text { (Barreto et al.2004) } \\
\end{array}$ & $64-27 \mathrm{ka}$ & & & & \\
\hline $\begin{array}{c}\text { Bahia-Sergipe } \\
\text { Foz de São Francisco e } \\
\text { Salvador } \\
\text { (Bittencourt et al. 1982, } \\
\text { Dominguez et al. 1996, } \\
\text { Barbosa 1997) }\end{array}$ & Qe1: >120 ka & Qe2: >5,1 ka & Qe3: $\ll 3,7$ ka & $\begin{array}{r}\text { Qe4: ativa, form } \\
400\end{array}$ & $\begin{array}{l}\text { da nos últimos } \\
\text { nos }\end{array}$ \\
\hline $\begin{array}{c}\text { Santa Catarina } \\
\text { Imbituba- } \\
\text { Jaguaruna(Giannini 1993, } \\
\text { Gianniniet al.2001,2007, } \\
\text { Sawakuchi 2003) } \\
\end{array}$ & $\begin{array}{l}\text { G1: iniciada antes ou } \\
\text { durante a última } \\
\text { transgressão } \\
\text { pleistocênica: } 174,8 \text { - } \\
50,8 \mathrm{ka} \\
\end{array}$ & $\begin{array}{l}\text { G2: iniciada antes ou } \\
\text { durante o alto NRM pós- } \\
\text { glacial 10,9-4,9 ka }\end{array}$ & $\begin{array}{c}\text { G3: fixada após a } \\
\text { transgressão holocênica } \\
6,3-0,2 \mathrm{ka}\end{array}$ & G4: & tiva \\
\hline
\end{tabular}

Pesquisas recentes, com datações LOE-SAR, possibilitam estender a presença de quatro gerações principais para a costa do Maranhão (Guedes et al. 2011b) e centro-norte de Santa Catarina (Mendes et al. 2015), porém com indícios de existência de gerações mais 
antigas. Na costa do Maranhão, estado vizinho a W, Guedes (2012) e Guedes et al. (2011, 2013) encontraram, em afloramentos de paleodunas terrígenas com espessura de dezenas de metros, idades LOE sugestivas de várias gerações antigas $(118.6 \pm 9.9,145.3 \pm 12.6 \mathrm{e}$ $239.8 \pm 20.4 \mathrm{ka})$. A geração eólica mais antiga (G1/G0, Guedes 2012) é encontrada com frequência em contato com o topo da Formação Barreiras, este identificado pela abundância de crostas ferruginosas. Ela apresenta intercalações das areias bem selecionadas com depósitos areno-conglomeráticos subaquosos, cuja frequência e espessura decrescem para cima (Guedes 2012). Corresponde ao que em alguns mapas da região (CPRM 2004) é descrito como "Pós-Barreiras" e que tem expressão em grande parte da Região Nordeste.

Já as dezenas de idades obtidas na costa leste do Maranhão por Guedes (2012) e Guedes et al. $(2011,2013)$ em superfície, correspondentes à última geração de paleodunas, caem todas dentro de um intervalo restrito de tempo, de 19 a 14 ka, com tendência para idades cada vez mais novas à medida que se afasta da costa. Estas idades, interpretadas como de estabilização do campo de dunas, coincidem com o último evento climático Heinrich (H1), tido como de deslocamento da ZCIT para sul na América do Sul (Arz et al. 1999, Weldeab et al. 2006, Baker et al. 2009), com aumento pronunciado de umidade em todo o território brasileiro (Cruz et al. 2009), e considerada por Guedes et al. (2013) ainda como de enfraquecimento dos ventos alísios na região.

\subsection{Tipologia de elementos morfológicos eólicos costeiros}

De acordo com Hesp (2000), os depósitos eólicos costeiros podem ser classificados em quatro grandes tipos: dunas frontais, rupturas de deflação (blowouts), dunas parabólicas (termos definidos no Quadro 2) e campos de dunas livres. A estes quatro tipos, pode-se acrescentar ainda um quinto, os lençóis de areia (sand sheets) (Giannini et al. 2005). Todos estes tipos são encontrados na área de estudo (Figuras 2.1 e 2.2)

Embora útil em enfoques mais generalistas, a classificação nestes cinco grandes tipos de depósitos eólicos abarca escalas distintas, já que frontais (Figura 2.2a), rupturas de deflação e dunas parabólicas (Figura 2.2b) são frequentemente feições ou formas de leito simples, individuais, enquanto campos de dunas livres (Figura 2.2c) e lençóis de areia (Figura 2.2d) são geralmente compostos e com dimensões muito maiores.

Campos de dunas livres correspondem a depósitos de areia eólica de grande escala (hectométrica ou maior), em movimento rumo ao interior ou, mais raramente, subparalelo à costa (Giannini et al. 2005, Martinho et al. 2006). Os campos de dunas que se movem ao interior transversalmente à costa são designados campos de dunas transgressivos (transgressive dune fields), termo introduzido por Gardner (1955). Os campos de dunas livres brasileiros contêm, invariavelmente, cordões de precipitação (ver definição no Quadro 2) e/ou dunas de orientação transversal ao vento efetivo (Figuras 2.2c, $2.2 \mathrm{f}$ e 2.1d), com crista linear, em meia lua (barcanas) ou sinuosa (barcanoides) (Giannini et al. 2005, Giannini 2007).

Lençóis de areia (sandsheets) são massas de areia eólica em movimento com pouco relevo, isto é, sem superimposição de dunas com faces de avalancha (Figura 2.2d) 
(Kocurek \& Nielson, 1986). Podem possuir, porém, feições como nebkhas (Quadro 2) e protodunas (Quadro 3). Em áreas com elevada relação entre energia eólica e suprimento ou com trânsito rápido de sedimentos, lençóis de areia desenvolvem-se no lugar ou a sotavento de campos de dunas livres (Tomazelli 1990, Giannini 2007. Giannini et al. 2014).

Abordagens mais detalhadas, inspiradas em exemplos brasileiros, e baseadas no grau de influência morfodinâmica da vegetação, foram propostas por Giannini et al. (2005, 2011, 2014), Martinho et al. (2006) e Giannini (2007). Estas propostas, adotadas nesta dissertação, abrangem várias outras classes de depósitos, além dos cinco citados. Entre aquelas com influência morfodinâmica da vegetação (Quadro 2), destacam-se: rastros lineares residuais, retrocordões (Figura 2.2f), planícies interdunas (Figuras 2.2f e 2.1c) e montes residuais (Figura 2.1b), além das já mencionadas dunas frontais e dunas parabólicas. E entre os sem influência da vegetação (Quadro 3), destacam-se dunas barcanas (Figura 2.1d) e cadeias barcanoides.

Quadro 2. Definições para feições eólicas costeiras formadas sob influência morfodinâmica da vegetação, segundo Steenstrüp (1894 apud Howell 1960), Hesp (1983, 1988, 2000), Giannini et al. (2005), Martinho et al. (2006) e Giannini (2007). Modificado de Hilbert (2013). Todas estas feições encontram-se na área de estudo.

\begin{tabular}{|c|c|c|}
\hline Feição eólica & $\begin{array}{c}\text { Termo usual na } \\
\text { literatura } \\
\text { internacional }\end{array}$ & Definição \\
\hline Duna frontal & Foredune & $\begin{array}{l}\text { Depósito formado na pós-praia ou na antepraia superior, como resultado } \\
\text { da retenção de areia costeira pela vegetação pioneira (Figura 2.2a). Pode } \\
\text { passar de incipiente a estabelecida, com o aumento relativo de altura, } \\
\text { complexidade morfológica e diversidade de cobertura vegetal }\end{array}$ \\
\hline Ruptura de deflação & Blowout & $\begin{array}{l}\text { Feição mista (erosivo-deposicional), gerada por retirada, via deflação e } \\
\text { redeposição local pelo vento, de depósitos arenosos preexistentes, como } \\
\text { dunas frontais ou cristas praiais. A ruptura faz-se através da produção de } \\
\text { bacia deflacionária, delimitada por paredes erosivas sub-paralelas que se } \\
\text { fecham, rumo sotavento, em lobos deposicionais em forma de U, } \\
\text { contendo faces de avalancha ou slipfaces }\end{array}$ \\
\hline Duna parabólica & Parabolic dune & $\begin{array}{l}\text { Feições com geometria em planta em } \mathrm{U} \text { ou } \mathrm{V} \text {, com convexidade voltada } \\
\text { para sotavento, formada por evolução, via migração, daruptura } \\
\text { deflacionária, da qual diferem pelo maior alongamento das paredes } \\
\text { (sugere-se aqui mais que três vezes a largura), as quais adquirem forma } \\
\text { de rastro linear residual. }\end{array}$ \\
\hline $\begin{array}{l}\text { Rastro linear } \\
\text { residual }\end{array}$ & Trailing ridge & $\begin{array}{l}\text { Cordão resultante da fixação, por vegetação, de braço alongado de dunas } \\
\text { parabólicas, ou da terminação de duna barcana ou cadeia barcanoide } \\
\text { parabolizadas, deixados para trás à medida que as dunas migram (Figura } \\
\text { 2.2e) }\end{array}$ \\
\hline $\begin{array}{l}\text { Retrocordão (ou } \\
\text { marca de migração } \\
\text { dunar) }\end{array}$ & $\begin{array}{l}\text { Gegenwallen, } \\
\text { residual dune ridge }\end{array}$ & $\begin{array}{l}\text { Cordão depositado por vento reverso, em meio a vegetação da planície } \\
\text { deflacionária, na margem barlavento de campos de dunas livres, com } \\
\text { sazonalidade controlada pela umidade da areia (Figura } 2.2 \mathrm{f} \text { ) }\end{array}$ \\
\hline Nebkha & Nebkha & $\begin{array}{l}\text { Montículos de areia depositados em meio a vegetação (Figura 2.1q). } \\
\text { Pode ser assimétrico, quando recebe o nome de duna de sombra (shadow } \\
\text { dune). }\end{array}$ \\
\hline Monte residual & Remnant knob & $\begin{array}{l}\text { Morrote, em meio a campo de dunas, remanescentes da erosão de um } \\
\text { depósito eólico, geralmente antigo cordão de precipitação (Figura } 2.1 \mathrm{~b} \text { ) }\end{array}$ \\
\hline $\begin{array}{l}\text { Cordão de } \\
\text { precipitação }\end{array}$ & Precipitation ridge & $\begin{array}{l}\text { Depósito de forma cônica e alongada localizado ao longo das margens } \\
\text { laterais e, às vezes, frontais, dos campos de dunas livres (Figura 2.1c) }\end{array}$ \\
\hline Planície interdunas & Interdune plain & $\begin{array}{l}\text { Área aproximadamente plana situada entre dunas transversais ou } \\
\text { barcanoides, onde a deflação predomina sobre a deposição eólica e onde } \\
\text { processos deposicionais não eólicos são tão ou mais atuantes que os } \\
\text { eólicos (Figura 2.1d) }\end{array}$ \\
\hline
\end{tabular}


Quadro 3. Definições para feições eólicas costeiras formadas sem influência morfodinâmica significativa da vegetação, segundo Kocurek et al. (1992), Hesp (2000), Giannini et al. (2005), Martinho et al. (2006) e Giannini (2007). Modificado de Hilbert (2013). Todas as feições foram vistas na área de estudo, exceto protodunas.

\begin{tabular}{|c|c|l|}
\hline Feição eólica & $\begin{array}{c}\text { Termo usual na } \\
\text { literatura } \\
\text { internacional }\end{array}$ & Definição \\
\hline Protoduna & Protodune & $\begin{array}{l}\text { Forma de leito eólicas dômica ou alongada com orientação transversal } \\
\text { ao vento efetivo, com até poucos metros de altura e sem face de } \\
\text { avalancha }\end{array}$ \\
\hline Duna barcana & Barchan dune & Duna em meia lua com concavidade voltada para sotavento \\
\hline Cadeia barcanoide & $\begin{array}{c}\text { Barchanoid chain, } \\
\text { crescentic dune }\end{array}$ & $\begin{array}{l}\text { Conjunto de dunas barcanas lateralmente coalescidas, com crista sinuosa } \\
\text { transversal ao vento efetivo }\end{array}$ \\
\hline $\begin{array}{c}\text { Depressão } \\
\text { interdunas }\end{array}$ & $\begin{array}{l}\text { Interdune } \\
\text { depression } \\
\text { de uma duna e a frente da duna à retaguarda }\end{array}$ \\
\hline Lobo deposicional & Depositional lobe & $\begin{array}{l}\text { Frente de avanço principal deum campo de dunas, com formato formato } \\
\text { parabólico, que migra, sobre terreno vegetado ou rochoso, no rumo do } \\
\text { vento efetivo }\end{array}$ \\
\hline
\end{tabular}

Os principais elementos morfológicos eólicos encontrados na área de estudo foram: duna frontal, ruptura de deflação, duna parabólica, rastro linear residual, retrocordão, nebkha, monte residual, cordão de precipitação, barcana e cadeia barcanoide (Figuras 2.1 e 2.2).

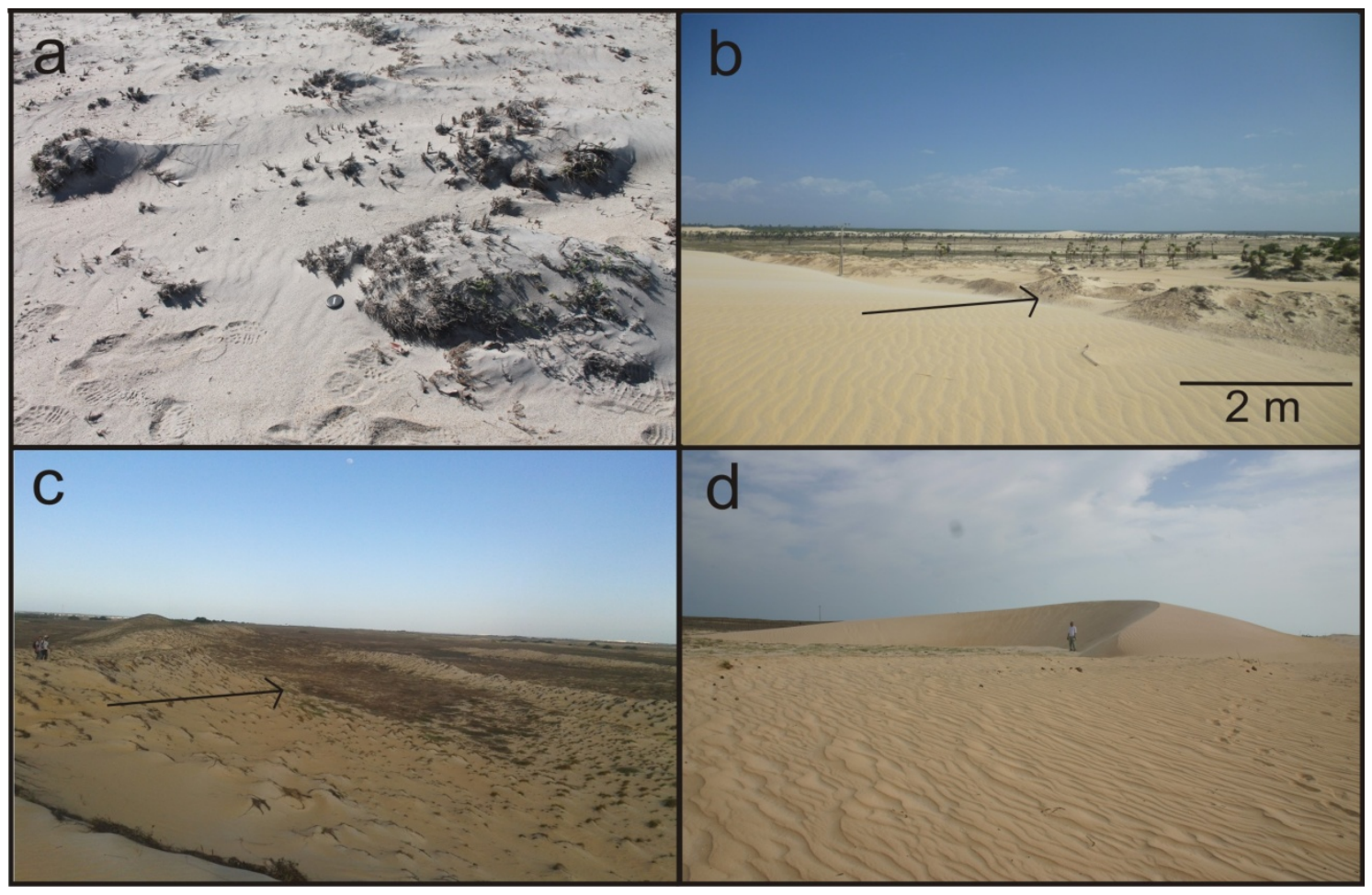

Figura 2.1. Elementos morfológicos de campos de dunas, ilustrados por exemplos da área de Luís Correia: a. nebkha, junto à praia de Carnaubinha; b. montes residuais; c. planície interdunas; e d. duna barcana na região perto a Luís Correia. 


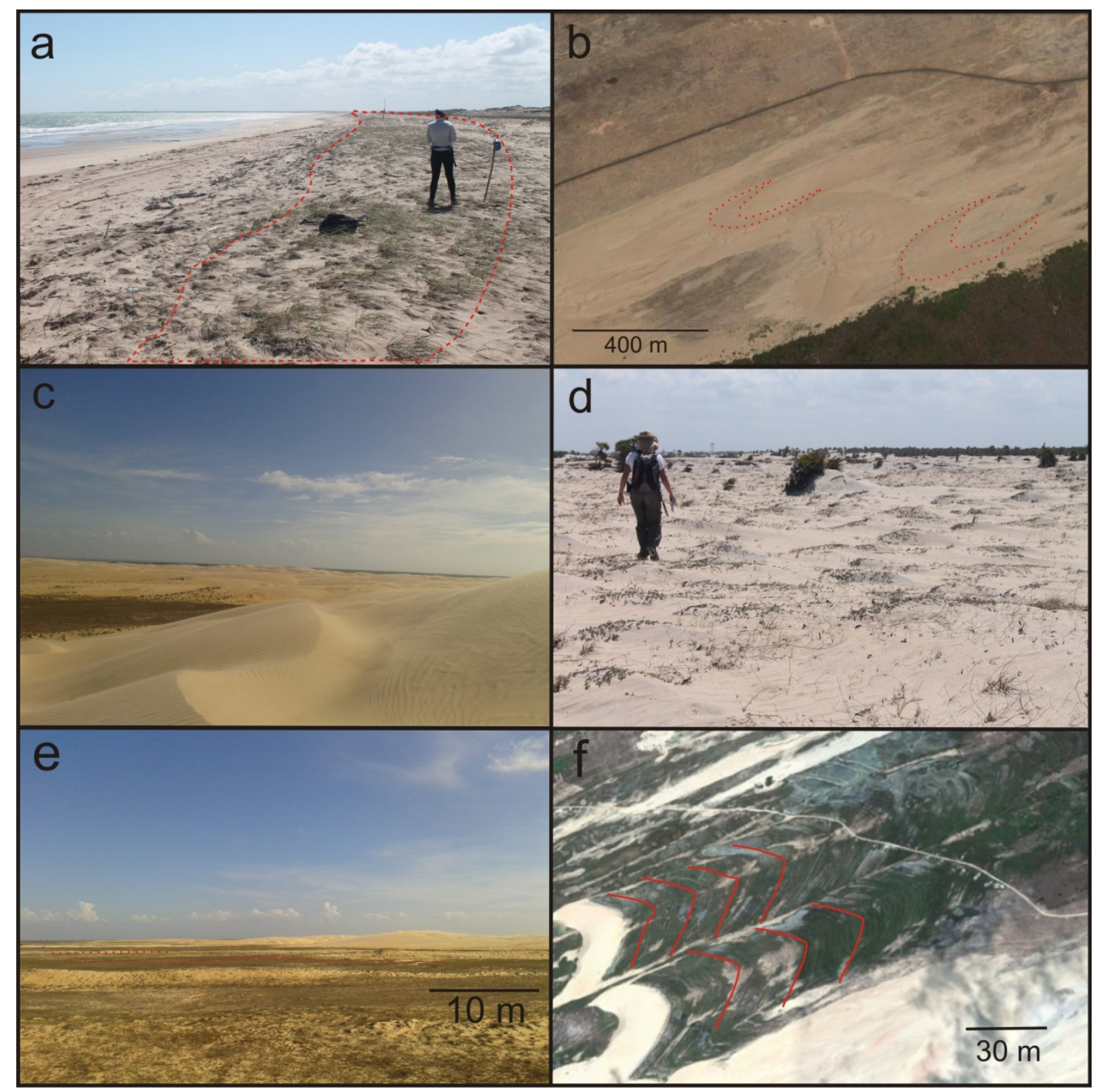

Figura 2.2. Outros elementos morfológicos de campos de dunas, ilustrados por exemplos da área estudada. a. duna frontal, na praia de Itaqui; b. dunas parabólicas coalescidas, próximo à praia de Macapá (imagem de satélite Google Earth); c. campo de dunas livres perto da Lagoa do Portinho, em Luís Correia; d. lençol de areia na praia de Carnaubinha; e. rastros lineares residuais, perto da cidade de Luís Correia; f. retrocordões, no campo de duna inativo de Bitupitá (imagem de satélite Google Earth).

Usando enfoque sistêmico, Giannini (2007) e Giannini et al. (2011, 2014) dividem os elementos morfológicos identificados nos depósitos eólicos costeiros do Brasil, quanto à sua função, em quatro grupos, de barla para sotavento (Figura 2.3): 1. de estoque inicial (dunas frontais, protodunas, lençóis de areia e dunas sem vegetação de orientação transversal ao vento); 2. de deflação (rupturas de deflação, rastros lineares residuais, retrocordões e dunas parabólicas); 3. de superposição ou cavalgamento (dunas barcanas e cadeias barcanoides); e 4. de avanço (cordões de precipitação e lobos deposicionais).

Segundo esses autores, sob condição de desequilíbrio construtivo (influxo maior que efluxo) em dado grupo funcional de elementos morfológicos, o excesso de areia tende a ser consumido na formação e alimentação de grupo a sotavento. Os grupos funcionais 
constituem, portanto, domínios espaciais interligados, com posição e morfologia definida dentro do sistema, e sob esse aspecto, constituem associações de elementos deposicionais. Desse modo, os elementos de estoque inicial compõem a associação praia-duna; os elementos de deflação reúnem-se na associação planície deflacionária; e os elementos de cavalgamento e de avanço definem a associação campo de dunas livres (Figura 2.3).

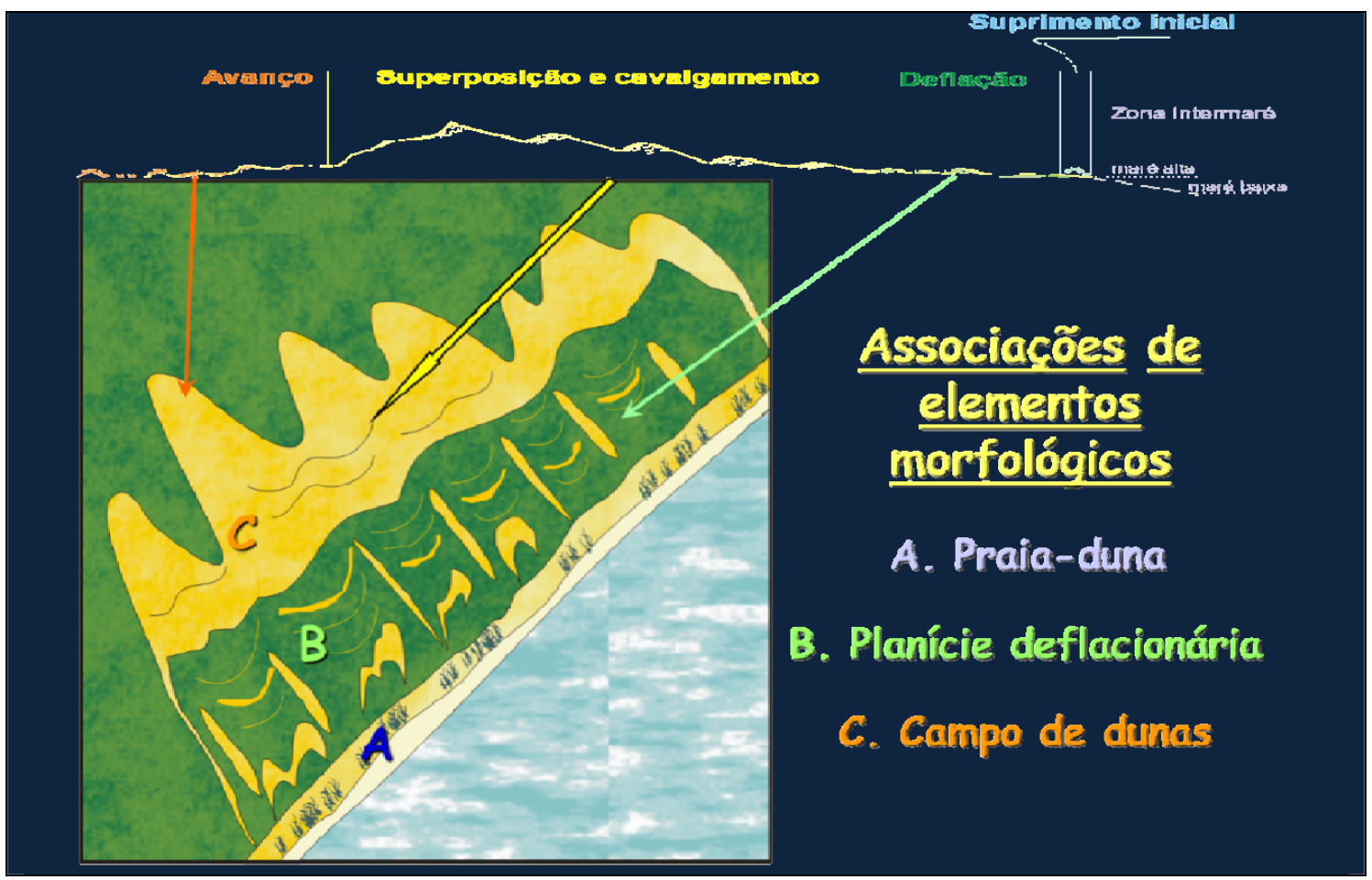

Figura 2.3. As três associações de elementos morfológicos em sistemas eólicos costeiros ativos do Brasil (A, B e C) e suas funções no funcionamento do sistema (perfil no alto da figura). Adaptado de Giannini (2007).

\section{5. Área de estudo}

\subsubsection{Variação do NRM}

O NRM máximo admitido na costa do Brasil para o Penúltimo Interglacial (120 ka AP) é de $8 \mathrm{~m} \pm 2 \mathrm{~m}$ acima do nível atual (Suguio et al. 2005), estimado a partir das altitudes de terraços de construção marinha essencialmente arenosos e na datação U/Th de fragmentos de corais neles encontrados no Estado da Bahia (Bernat et al. 1983).

Para o Holoceno, a curva teórica de NRM de Milne et al. (2005), modelada para o Caribe e a América do Sul com base em cálculos de transferência de massa das calotas de gelo para o oceano mais ajustes hidro-isostáticos regionais, indica taxa de subida do NRM de 7 a $8 \mathrm{~mm}$ por ano até 7000 anos A.P., com desaceleração abrupta a partir de então. Desse período até o presente, o modelo sugere variações de no máximo $1 \mathrm{~m}$ no nível eustático, com possibilidade, porém, de variações locais a sub-regionais pouco maiores, por conta de ajustes isostáticos. 
Angulo et al. (2006), em análise crítica de indicadores biogênicos (vermetídeos) disponíveis na literatura até então para o litoral entre Paraná e Pernambuco, deduziram declínio suave de NRM após o máximo de 3 a 4 m, alcançado entre 7000 e 5000 anos cal A.P.. Tendência semelhante foi encontrada por Caldas et al. (2006) no litoral do Rio Grande do Norte, utilizando datações de beach-rocks e sedimentos lagunares, e por Vasconcelos et al. (2014), no Ceará, com datações de beach-rocks e de eolianitos. Segundo estes autores, o NRM durante o Holoceno não foi superior a $3 \mathrm{~m}$ acima do atual.

Também na costa cearense, Irion et al. (2012), com base no nivelamento de beachrocks, não encontraram evidências de paleonível holocênico mais alto que o atual e inferiram que o NRM nessa costa continuaria em elevação, seguindo a tendência da componente glácio-eustática do NRM. O nivelamento, porém, não foi feito em relação às fácies homólogas, como metodologicamente recomendável (Angulo, 2015). Além disso, não há clara menção ao tipo de material datado, se bioclasto (fornecedor de idade máxima) ou se cimento (fornecedor de idade mínima). Desse modo, estes dados são pouco precisos para a reconstituição do comportamento do NRM. Para o Estado do Piauí, não existem curvas de variação no NRM holocênico específicas.

As curvas de NRM holocênico de Angulo et al. (2006), Caldas et al. (2006) e Vasconcelos et al. (2014) são compatíveis entre si, em suas linhas mais gerais, bem como com o modelo teórico de Milne et al. (2005). Serão, por esta razão, as adotadas neste trabalho.

\subsubsection{Clima}

O clima do Nordeste do Brasil é fortemente influenciado pela variação daZona de Convergência Intertropical (ZCIT), faixa de umidade cuja posição é, por sua vez, controlada pelo gradiente de temperatura da superfície marinha (TSM) entre o Atlântico Sul e o Norte (Uvo 1989, Melo et al. 2009). A faixa de umidade é atraída para as zonas de aumento de temperatura. Assim, a ZCIT tem variação anual, com posição mais ao norte durante o verão do hemisfério norte e posição mais ao sul durante o verão austral (Cavalcanti et al. 2009). As costas de Piaú e Ceará situam-se ligeiramente a norte da posição meridional máxima da ZCIT, no verão austral (Figura 2.4), tendo por esta razão chuvas concentradas (acima de $100 \mathrm{~mm} / \mathrm{mês}$ ) entre o verão (janeiro) e o outono (maio). $\mathrm{O}$ clima é quente tropical, com média mensal mínima de temperatura de $22^{\circ} \mathrm{C}$ e máxima de $32^{\circ} \mathrm{C}$ e precipitação média anual entre 1000 e $1200 \mathrm{~mm}$. 


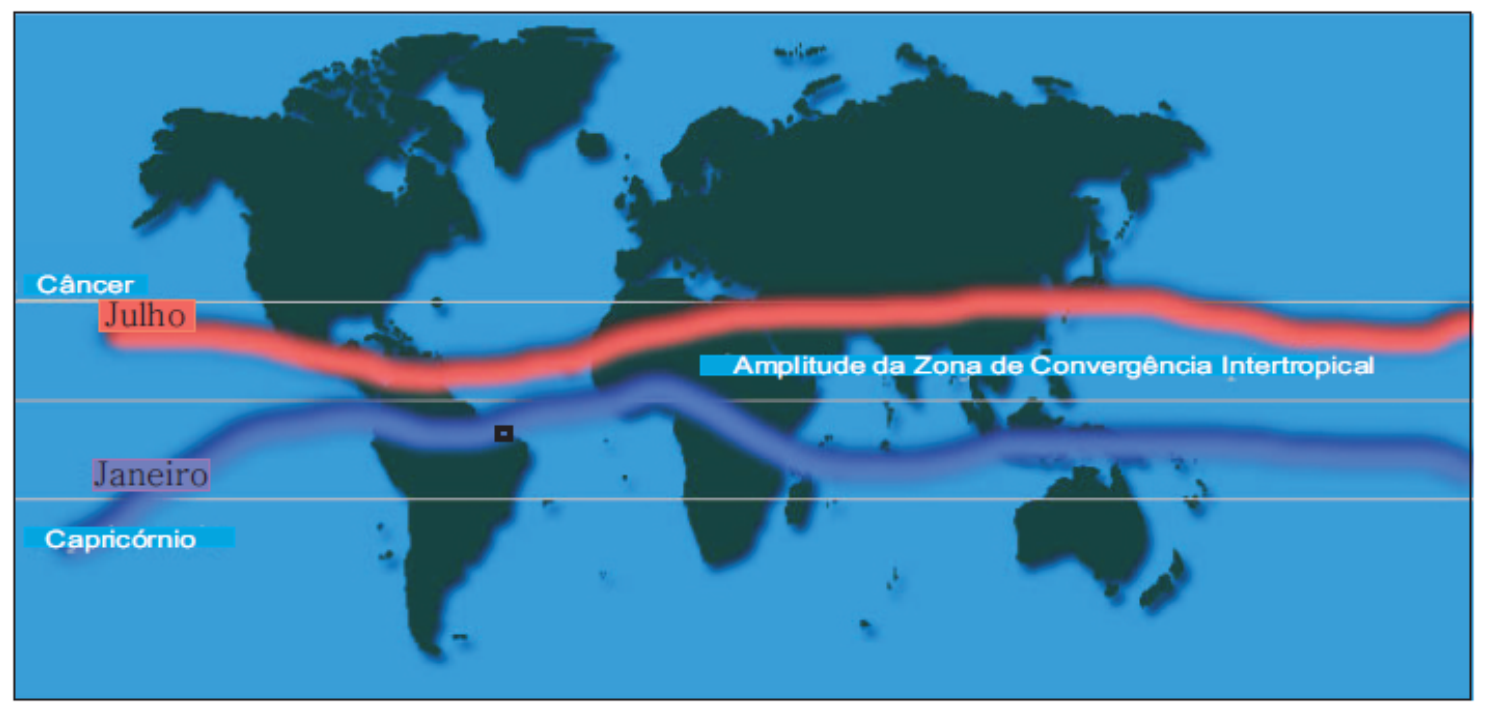

Figura 2.4. Localização da Zona de Convergência Intertropical no inverno (vermelho) e no verão (lilás) austrais, com indicação da área de estudo (quadrado preto).

Para a formação de depósitos eólicos, os aspectos climáticos que têm mais importância são os regimes de ventos e de chuvas; o vento atua como agente de transporte sedimentar, mas, para ser efetivo, deve ter à sua disposição sedimentos livres de umidade. Desta maneira, para entender a localização e orientação de campos de dunas, torna-se necessário avaliar a frequência e velocidade dos ventos (variáveis determinantes da deriva eólica potencial ou DEP) e a distribuição da pluviosidade (que combinada com a DEP e o aporte sedimentar, determina a derivaeólica efetiva ou DEE) (Giannini et al. 2005, Giannini 2007, Mendes, 2012, Mendes \& Giannini 2015). Na Figura 2.5, está representada a variação anual da DEP registrada desde os anos 1970/80 nas duas estações do Instituto Nacional de Meteorologia (Inmet) mais próximas às áreas de estudo no Piauí e no Ceará, isto é, Parnaíba e Acaraú, respectivamente. Os valores máximos de DEP anual no período estudado são mais elevados na estação meteorológica de Parnaíba (140 unidades vetoriais ou uv) que na de Acaraú (80uv). Nota-se aumento da DEP, comum às duas estações, nos anos de 1982 e 1998, ambos apontados como anos de El Niño "muito forte" (Gweather 2015), o que sugere que este fenômeno possa exercer controle sobre a intensidade do vento em escala regional. 


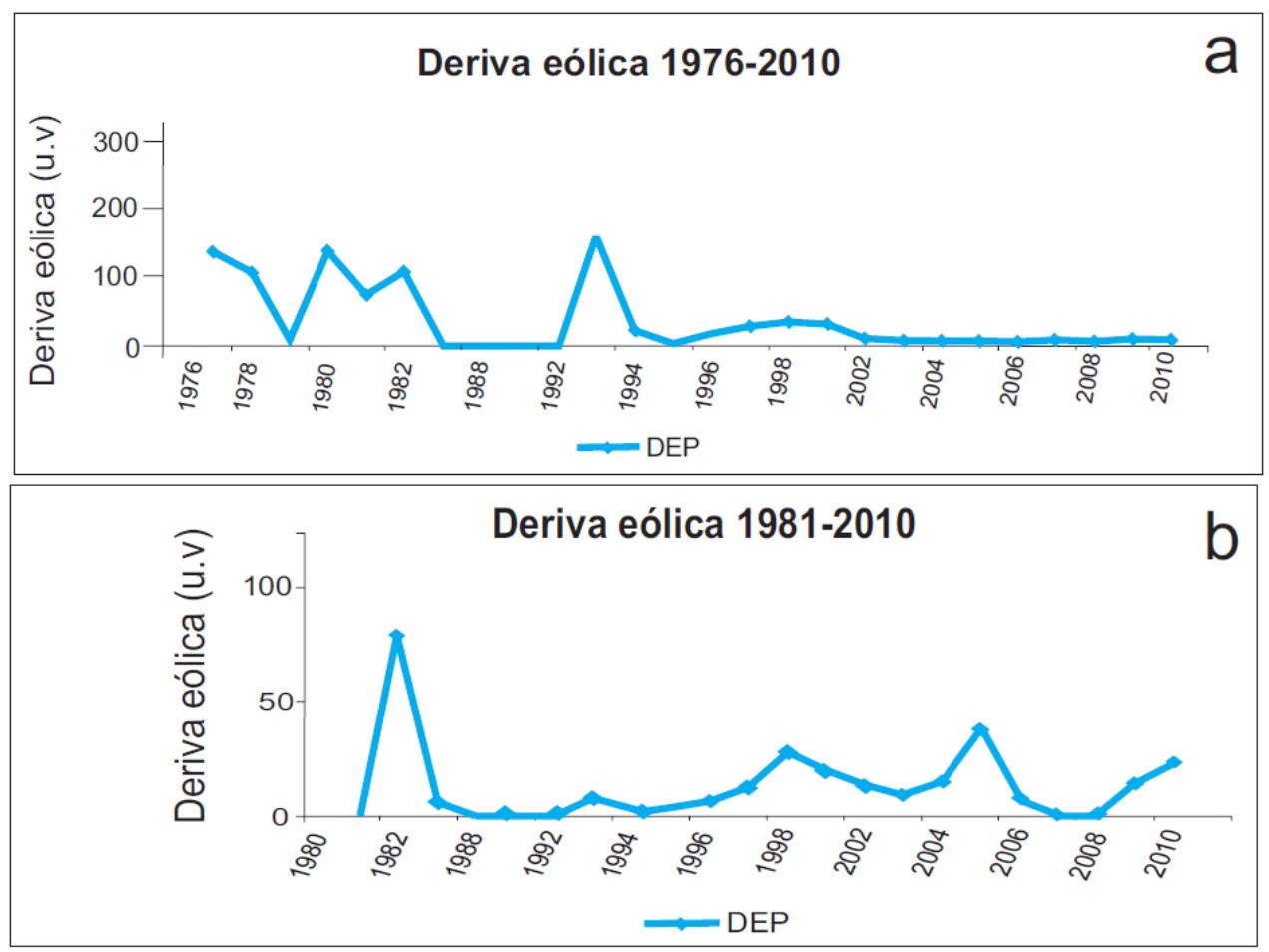

Figura 2.5. Variação anual da deriva eólica (DEP) nas estações meteorológicas Inmet de: a.Parnaíba (PI), período 1976-2010; b. Acaraú (CE), período 1981-2010. Cálculo feito com os dados de velocidade média para cada ano, pela formula de Lettau \& Lettau (197 apud Fryberger 1979), conforme descrito em Mendes \& Giannini (2015); os dados destasestações estão disponíveis no sítio eletrônico http://www.inmet.gov.br/portal/

Acredita-se que o deslocamento da ZCIT verificado sazonalmente ocorra também em escalas de tempo mais duradouras, por efeito de mudanças de insolação ligadas aos ciclos orbitais (Cruz et al. 2005, 2009) ou eventos milenares. Assim, nos momentos de resfriamento do hemisfério norte, como máximos glaciais e eventos Heinrich e Bond, a faixa de umidade da ZCIT seria empurrada mais para sul, a exemplo do que acontece no inverno boreal. Estes deslocamentos podem ter variado, dependendo da região, de pouco menos de $1^{\circ}$ a pouco mais de $5^{\circ}$ de latitude (McGee et al. 2014). Em tese, a costa do Piauí e oeste do Ceará ficaria, por exemplo, entre as posições médias da ZCIT do verão e do inverno, o que possivelmente não só mudaria como expandiria a época de concentração de chuvas. Entretanto, a Região Nordeste, por situar-se entre o limite sul da ZCIT e o limite leste da SMAS, possui comportamento muito particular. Pelo menos no que se refere ao aumento de insolação do ciclo de precessão verificado no hemisfério sul no Holoceno superior, o padrão do Nordeste é anti-fásico em relação à grande parte do continente sulamericano (Cruz et al. 2009). Assim, o avanço para sul das duas zonas de umidade, ZCIT e ZCAS, nos últimos 5000 anos, implicou umidificação do clima no Sul e no Sudeste do país, em prejuízo da umidade na Região Nordeste. 


\subsubsection{Ondas e deriva litorânea}

A região em estudo expõe-se à ação de ondulações (swell waves) de $\mathrm{N}$, geradas nos ciclones extratropicais do Hemisfério Norte, e de vagas locais (wind sea waves), que, no Piauí-Ceará, são forçadas pelos ventos alísios de SE a NE (Pianca et al. 2010, Costa 2014).

A atuação das ondulações de $\mathrm{N}$ concentra-se no verão austral, quando ocorre ainda a ampliação para sul da zona de influência das vagas geradas pelos alísios de NE. No restante do ano, dominam as vagas de E a SE (Pianca et al. 2010). As vagas geradas por ventos alísios favorecem a deriva litorânea para $\mathrm{W}$ na costa setentrional do Nordeste brasileiro, rumo no qual se observa aumento da proporção de terrígenos na sedimentação costeira.

\subsubsection{Plataforma continental}

A plataforma continental nordestina é estreita, com média de $63 \mathrm{~km}$ de largura, e geralmente é mais rasa que $200 \mathrm{~m}$. Em contraste com outras plataformas tropicais, a presença de recifes de corais é inexpressiva, já que apenas alguns dos gêneros construtores de recifes estão presentes. Os sedimentos terrígenos são, na sua grande maioria, relíquias, retrabalhados pelo menos desde o início do Holoceno (Kowsmann \& Costa 1979) e, na interpretação de Vital (2005), sua semelhança composicional com os sedimentos recentes sugere que no Pleistoceno o clima teria sido similar ao atual. No Nordeste brasileiro, a amplitude de marés (mesomaré) e os ventos fortes de quadrantes de leste dão alta energia à frente plataformal.

Tendo como base a morfologia e a distribuição dos tipos de sedimentos, Coutinho (1976) divide a plataforma do Nordeste em interna (até a isóbata de 20m), média (entre as isóbatas de 20 e 40m), de relevo bem mais regular, e externa (mais profunda que $40 \mathrm{~m}$ ). Segundo Araújo (2011), a plataforma cearense atinge sua largura máxima de $75 \mathrm{~km}$ junto a Camocim, e a mínima de $41 \mathrm{~km}$ em Tremembé.Análises batimétricas realizadas em Acaraú (Araújo 2011) e Camocim (Chagas 2013) indicam que a plataforma continental nestes locais apresenta gradiente de declividade não superior a 3\%, com caimento direcionado para o norte.A plataforma continental do trecho que vai de Luís Correia (PI) a Mundaú (CE) é composta principalmente por sedimentos carbonáticos na granulação cascalho, dominados por algas coralináceas (Kowsmann \& Costa1979, Cavalcanti 2011; Figura 2.6), ainda que sedimentos quartzo-arenosos sejam dominantes na parte mais rasa da plataforma interna; já no Estado de Maranhão, e a E de Fortaleza, a plataforma passa a ser de constituição essencialmente terrígena (Kowsmann \& Costa 1979). 


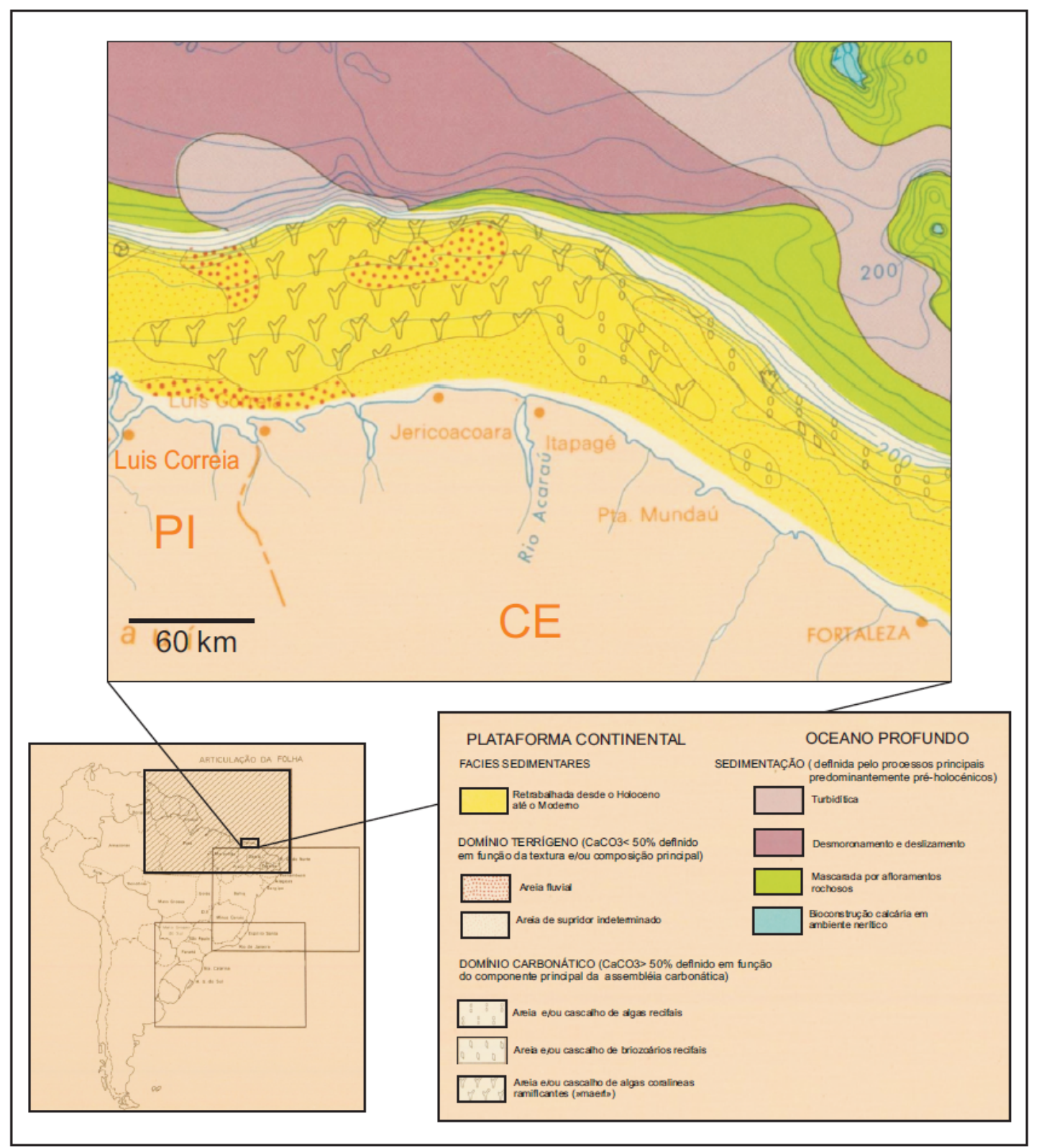

Figura 2.6. Plataforma continental da área de estudo, com representação dos tipos de sedimentos nos domínios terrígeno e carbonático. Notar que a região de concentração de eolianitos, que vai de Luís Correia (PI) a Mundaú (CE), coincide com a distribuição do domínio carbonático na plataforma interna e média, e também com a de algas coralíneas ramificantes. Extraído do Projeto Remac (Kowsmann \& Costa 1979).

\subsubsection{Geomorfologia e geologia}

As formas de relevo da região costeira do Piauí e Ceará compreendem superfícies tabulares reelaboradas (chapadas baixas), com topo plano a suavemente ondulado, cujas altitudes alcançam até $250 \mathrm{~m}$, e planície litorânea com cotas de até poucas dezenas de metros (e.g., 10 m, na área urbanizada de Luís Correia, e 21m, na de Fortaleza) (Souza 2000, Aguiar \& Gomes 2004).

As chapadas baixas correspondem a coberturas sedimentares neógenas, dominadas por arenitos e lamitos arenosos atribuídos à Formação Barreiras. E a planície litorânea abarca desembocaduras flúvio-estuarinas e de canais de escoamento de maré associados a 
manguezais, turfas e areias, com destaque, entre estas, para dunas eólicas ativas e inativas (Souza 2000, Aguiar \& Gomes 2004) ou "fixas" (Claudino Sales 2002). Corpos de água lacustres remanescentes de antigos estuários também podem ocorrer em meio à planície litorânea, inclusive como resultado da obstrução de drenagens costeiras pelo avanço ao interior de dunas e paleodunas (Souza 2000). Exemplos de lagos barrados pelos depósitos eólicos na costa do Piauí são as lagoas Portinho, Jabuti e Sobradinho, entre Luís Correia e Cajueiros da Praia (Figura 2.7); na costa do Ceará, lagos de obstrução de drenagem são exemplificados pelas lagoas Cangalhas e Boqueirão, em Camocim (Figura 2.8).

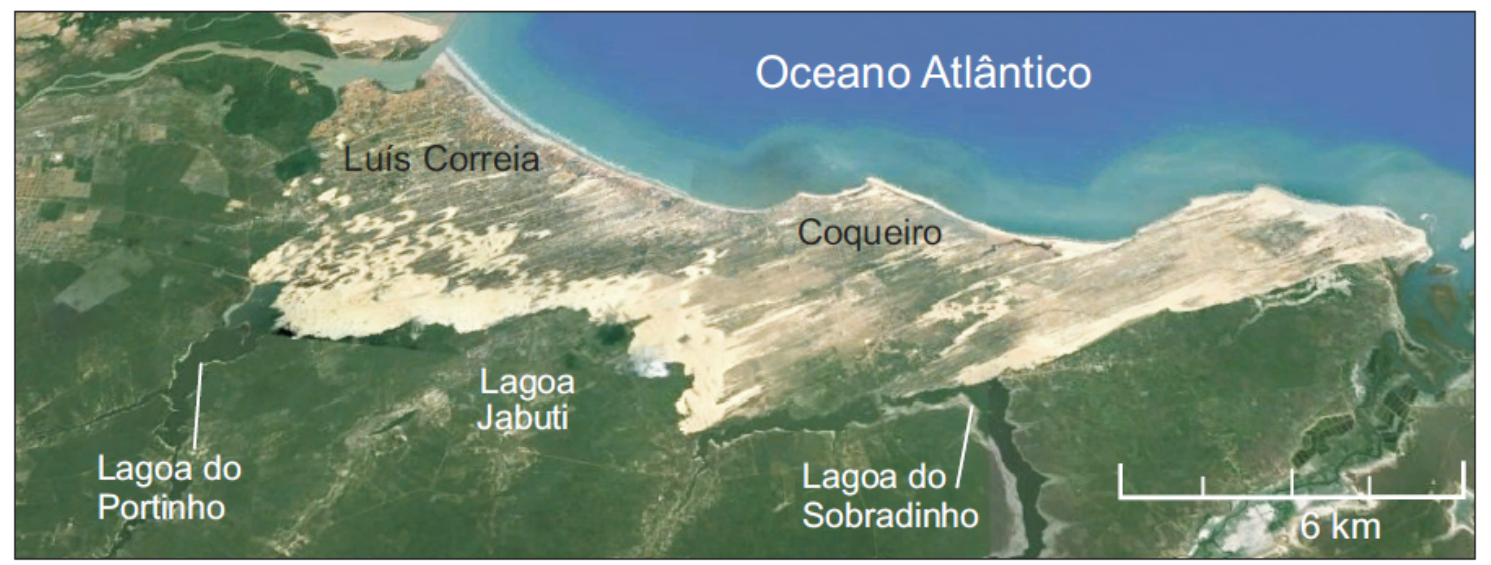

Figura 2.7. Exemplos de lagos associados à obstrução de drenagens costeiras pelo avanço ao interior de dunas e paleodunas, no Piauí.

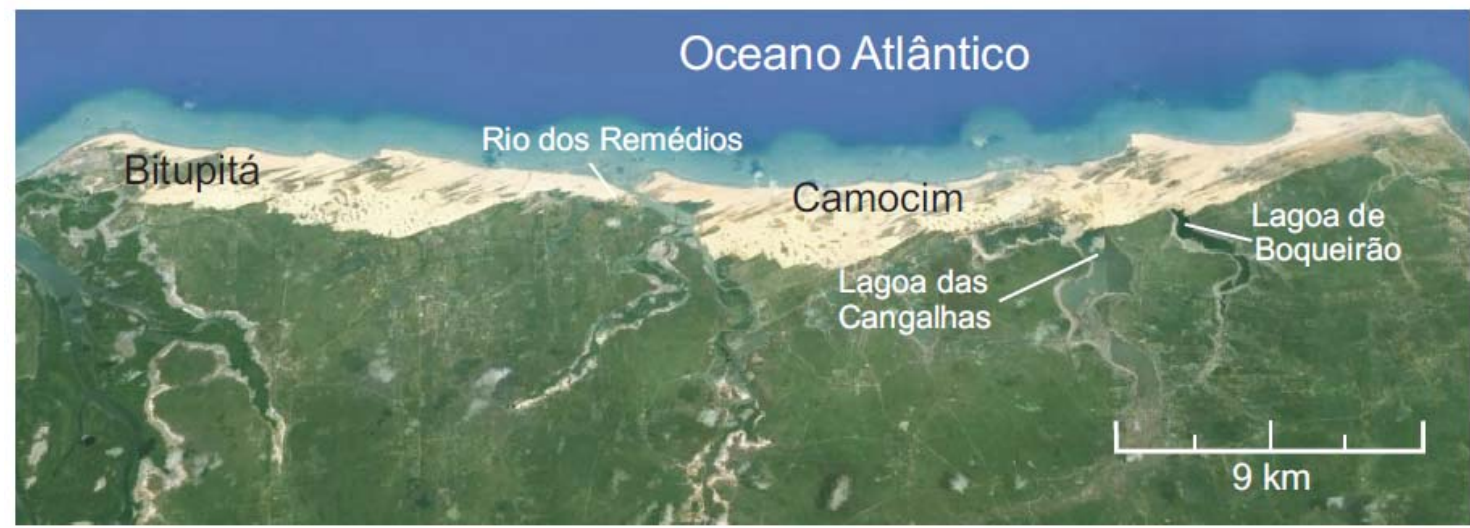

Figura 2.8. Exemplos de lagos associados à obstrução de drenagens costeiras pelo avanço ao interior de dunas e paleodunas, no Ceará.

Claudino Sales (2002) separa as dunas ativas do Ceará em "móveis" e "semi-fixas", termos usados para designar respectivamente as feições sem e com participação essencial da vegetação na sedimentação. Classificação similar foi usada para as feições eólicas do Piauí por Pfaltzgraff (2010). As "dunas móveis", ou livres, incluem barcanas e cadeias barcanoides (Giannini et al. 2005); e as "semi-fixas" abrangem dunas frontais, nebkhas, blowouts e dunas parabólicas (Claudino Sales 2002, Giannini et al. 2005).

No Piauí, parte das "dunas fixas" (paleodunas) repousa discordantemente sobre os sedimentos da Formação Barreiras. Em alguns setores, encontram-se rebaixadas quase ao nível dos tabuleiros, com suas formas dissipadas pela erosão superimposta; em outros, preservam feições deposicionais mais espessas, como cadeias barcanoides, que são vistas 
nas imagens de satélite. Em termos direcionais, apresentam notável concordância com o deslocamento das dunas recentes, isto é, de NE para SW (Pfaltzgraff 2010). Lehugeur (1995) descreve um campo de paleodunas próximo à praia, entre as localidades de Luís Correia e Coqueiro (PI), cuja fixação é atribuída a capeamento arenoso escuro, de até 50 $\mathrm{cm}$ de espessura, com conchas inteiras e fragmentadas de gastrópodes.

No Ceará, Claudino Sales (2002) menciona a existência de "dunas fixas" ao longo de toda a extensão costeira, incluindo tanto depósitos sem formas definidas, estabilizados por vegetação florestal, quanto paleodunas parabólicas. Os eolianitos, presentes apenas no setor centro-ocidental (Maia 1998, Maia et al., 1999), adquirem, quando submetidos à deflação recente, morfologia ruineforme, descrita por Carvalho et al. (1994) como do tipo yardang (segundo Giannini 2007, termo introduzido por Hedin 1903-1905 apud Pye \& Tsoar 1990 para referir-se a calhas entre cristas alongadas, paralelas ao vento, esculpidas por deflação em depósito sedimentar consolidado).Uma questão ainda por investigar (inclusive nesta dissertação) é se a orientação destes yardangs de eolianito tem caráter apenas erosivo, ou se guarda também relação com as feições deposicionais que lhes deram origem.

Nos últimos anos, a evolução do conhecimento sobre os depósitos eólicos do Ceará tem permitido várias tentativas de classificação em diferentes gerações de dunas (Quadro 1), apesar de a questão permanecer em aberto, por escassez de dados de datação absoluta (Giannini et al. 2005). Dentre outros, Maia (1998), Claudino Sales \& Peulvast (2001, 2002), Claudino Sales (2002), Carvalho (2003) e Castro \& Ramos (2006) identificaram três gerações, além das dunas ainda em atividade, estas com idade de iniciação estimada entre 0,3/0,4 ka ("dunas D1", de Claudino Sales 2002, conforme Quadro 1) e 1,2 ka ("dunas D2" da mesma autora).

Claudino Sales (2002) atribui a geração de paleodunas denominada "dunas D3" ao intervalo entre o Holoceno Médio e 1,2 ka. O limite inferior corresponde à idade obtida por termoluminescência de duna parabólica hairpin situada no Pecém (Maia et al. 1999). Além destas parabólicas, a geração D3 incluiria campos de dunas fixos sem formas definidas e os eolianitos.

As paleodunas contemporâneas à transgressão holocênica e anteriores ao período de relativa estabilização de NRM do Holoceno superior receberam a denominação de "dunas D4". Grande parte dessas dunas acha-se encoberta pelas mais recentes. Em outros locais, elas representam campos de dunas descontínuos vegetados, que em Icapuí se estendem até $40 \mathrm{~km}$ ao interior (Claudino Sales \& Peulvast 2001, 2002). As paleodunas mais antigas que o início da transgressão holocênica, denominadas "dunas D5", representariam todas as acumulações cuja identificação individual ainda não foi feita, e estariam sustentando falésias inativas em diversos setores litorâneos.

Na costa do Piauí, ocorrências de eolianitos foram descritas por Baptista (2010) nas proximidades da praia do Coqueiro, localizada a W de Luís Correia, em meio a zonas deflacionárias extensas. De acordo com Giannini (2007), estas zonas deflacionárias da costa do Piauí apresentam rastros lineares residuais (feições definidas no Quadro 2) bastante conspícuos em seu interior. 


\section{Metas}

O que se apresenta como meta desta pesquisa de Mestrado responde à pergunta: até onde se pretende chegar? Baliza, assim, o alcance máximo ideal ou desafio maior da proposta. Neste sentido, a meta científica da pesquisa é estabelecer a cronologia dos sistemas deposicionais eólicos costeiros carbonáticos da costa do Piauí e Ceará, como ferramenta para compreender os fatores e processos controladores de sua iniciação, evolução, estabilização, preservação e decorrente distribuição espacial.

\section{Objetivos}

Os objetivos são entendidos aqui como aquilo que se planeja executar, de modo a alcançar a meta estabelecida. Nesse sentido, os seguintes objetivos específicos são enumerados:

1. Definir, com base em levantamento bibliográfico e cartográfico e em análise de imagens de satélite, a geometria e distribuição espacial das ocorrências de eolianitos nas áreas propostas para estudo e situá-las em relação aos elementos morfológicos de dunas e paleodunas de areia terrígena, bem como em relação às suas áreas fontes carbonáticas potenciais na plataforma continental interna.

2. Realizar análise de fácies deposicionais e levantamento estratigráfico em eolianitos escolhidos na etapa anterior e inferir o tipo de elemento morfológico a que correspondem.

3. Fazer a caracterização sedimentológica dos eolianitos, por fácies e/ou região, para comparação. Amostrar ainda o sistema praia duna-atual adjacente, para estudos de proveniência.

4. Obter a distribuição de idades de formação e estabilização dos eolianitos, a partir de datação absoluta por ${ }^{14} \mathrm{C}$ e luminescência

5. Como apoio e refinamento à caracterização faciológica e estratigráfica, avaliar a possibilidade de contrastes sedimentológicos/petrográficos (de granulometria, tipo de grão bioclástico e tipo de material intersticial) entre depósitos eólicos de diferentes fácies, gerações ou constituições (terrígenos versus carbonáticos, tipo de grão carbonático) e deduzir seus processos e fatores controladores.

6. Integrar o conjunto de resultados morfoestratigráficos, faciológicos, sedimentológicos e cronológicos, de modo a avaliar possíveis relações entre idades e variações de aporte sedimentar, bioclástico ou terrígeno, e assim poder vincular estas variações com mudanças ligadas a NRM, clima e/ou neotectônica.

\section{Meios, materiais e métodos}

\subsection{Sensoriamento remoto}

O trabalho de sensoriamento remoto teve como finalidade principal situar as ocorrências de eolianitos em relação a feições morfológicas de campos de dunas ativos e fósseis. Baseou-se em imagens do satélite Geo-Eye ldo software de livre acesso Google 
Earth ${ }^{\circledR}$ (resolução espacial de cerca de $1 \mathrm{~m}$ ), e nas do satélite Landsat acessíveis no sítio eletrônico da NASA (North America Spatial Agency) e fornecidas pelo Instituto Nacional de Pesquisas Espaciais (INPE). As imagens de satélite de alta resolução foram georreferenciadas e sobrepostas ao modelo digital de terreno, gerado a partir de imagens SRTM (Shuttle Radar Topography Mission - resolução espacial de $30 \mathrm{~m}$ na horizontal e 3 $\mathrm{m}$ na vertical), com uso dos softwares Global Mapper $13^{\circledR} \mathrm{e}$ Envi. Foram feitas tentativas de detecção automática de eolianitos nas imagens Landsat 5 e 8, com as bandas cromáticas $3,4,5,6$ e 7, sem porém obter bons resultados.

\subsection{Atividades de campo}

\subsubsection{Análise de fácies}

$\mathrm{Na}$ caracterização de sistemas deposicionais, os elementos básicos de descrição são as fácies, unidades sedimentares concretas, porém desconfinadas estratigraficamente (Walker 1976, Anderton 1985, Giannini 1993), delimitadas por mudanças de propriedades macroscópicas. Embora descritivas, as fácies assim definidas visam, em última análise, a interpretações de processos deposicionais. Deste modo, interessam na sua caracterização, sobretudo as propriedades que possam ter-se formado ou existido durante ou logo após a deposição (sindeposicionais e penecontemporâneas, respectivamente). O procedimento mais usual de análise de fácies divide-se em duas etapas: primeiro, as estruturas sindeposicionais permitem trançar correlações com a morfologia do depósito (leito sedimentar ou frente da duna, por exemplo), ou seja, correlações produto-forma; em seguida, a partir destas correlações e da assunção tácita de validade de correlações processo-forma, traçam-se correlações produto-processo (Giannini 2007).

Nos depósitos quaternários, a morfologia pode estar ainda preservada e ser assim observada diretamente no campo; portanto, considera-se a coexistência de fácies morfológicas, traçadas através da observação direta das relações processo-forma, e fácies morfo-deposicionais, baseadas na descrição de elos forma-produto (Giannini 2007).

Com base nesse enfoque, as principais atividades executadas durante as jornadas de campo nas áreas de dunas e paleodunas eólicas costeiras selecionadas foram: 1 . identificação e descrição de fácies e elementos morfológicos reconhecidos previamente no sensoriamento remoto; 2. análise de fácies deposicionais e associações de fácies, correspondentes, respectivamente, às fácies e elementos morfológicos identificados; esta análise foi feita principalmente em cortes naturais (de deflação ou erosão subaquosa), incluindo a confecção de croquis e seções colunares; 3. coleta sistemática, por fácies e/ou horizonte estratigráfico, de medidas de espessura e atitude de estratificação cruzada, com trena e bússola; 4. amostragem seletiva de sedimentos destinados a datação e a caracterização textural, mineralógica e petrográfica (teor de carbonatos, granulometria, microscopia óptica de luz polarizada e microscopia eletrônica de varredura).

Diferentemente do que costuma ocorrer em paleodunas quaternárias terrígenas de clima tropical, nas quais a pedogênese oblitera as estruturas sedimentares primárias, a 
análise de fácies nos eolianitos estudados foi facilitada pela abundância de estruturas sindeposicionais ou penecontemporâneas, principalmente laminação plano-paralela pouco inclinada e estratificação cruzada (inclusive acanalada-festonada), algumas com evidências superimpostas de paleossolos (horizontes de raízes cimentadas ou rizocreções e camadas com escurecimento gradual para o topo e gastrópodes continentais).

\subsubsection{Códigos de fácies}

As fácies deposicionais observadas no campo foram classificadas por meio de siglas tipo Xy, em que as iniciais maiúsculas (X) referem-se ao nome da rocha, com ênfase na granulação (arenito ou rudito), e as iniciais minúsculas após as maiúsculas (y) fazem alusão às estruturas sedimentares reconhecidas. Para simbolizar estas composições e estruturas, foram utilizadas as letras listadas no Quadro 4.

Quadro 4. Siglas adotadas para representar litologías e estruturas sedimentares, nos códigos de fácies, segundo a fórmula geral Xy

\begin{tabular}{|c|c|c|}
\hline Natureza da informação & Sigla & Descrição \\
\hline \multirow{2}{*}{$\begin{array}{c}\mathbf{X} \\
\text { Nome da rocha/depósito, com } \\
\text { ênfase na granulação }\end{array}$} & $\mathrm{A}$ & Arenito ou areia \\
\hline & $\mathrm{R}$ & Rudito \\
\hline \multirow{8}{*}{$\begin{array}{c}\mathbf{y} \\
\text { Estruturas sedimentares ou } \\
\text { conteúdo biológico } \\
\text { reconhecidos }\end{array}$} & $\mathrm{c}_{\mathrm{a}}$ & Estratificação cruzada de ângulo alto $\left(>10^{\circ}\right)$ \\
\hline & $c_{b}$ & Estratificação cruzada de ângulo baixo $\left(\leq 10^{\circ}\right)$ \\
\hline & $\mathrm{p}$ & Estratificação plano-paralela \\
\hline & $r_{a}$ & Rizoconcreções abundantes (>10\% em volume) \\
\hline & $r_{e}$ & Rizoconcreções escassas ( $\leq 10 \%$ em volume) \\
\hline & $\mathrm{g}$ & Presença de bioclastos ou vestígios in situ de gastrópodes \\
\hline & $\mathrm{b}$ & Presença de bioclastos (conchas) rudáceos \\
\hline & $\mathrm{m}$ & Maciço (sem estrutura sedimentar aparente) \\
\hline
\end{tabular}

\subsubsection{Coleta e códigos de amostras}

Ao todo foram coletadas 84 amostras, das quais 50 são de eolianitos, 13 de praias, seis de dunas ativas, oito de paleodunas terrígenas, duas de beach-rocks, uma da Formação Barreiras, uma de depósito "Pós-Barreiras" cascalho-arenoso, uma de calcirrudito de gastrópodes (ECE49), duas de arenitos calcíferos com gastrópodes in situ (EPI04 e ECE45), interpretados no campo como possíveis paleossolos. Deste total, 21 foram destinadas também a datação por LOE e 42 tiveram coleta de amostra indeformada para estudo petrográfico. Amostras de depósitos não eolianíticos coletadas para datação visaram dar contexto estratigráfico aos eolianitos. As estratégias foram: 1. datar por LOE feições eólicas terrígenas fósseis com morfologia similar a dos eolianitos (caso da amostra EPI02), para ter ideia dos intervalos de tempo sem cimentação carbonática; 2. datar por ${ }^{14} \mathrm{C} \mathrm{o}$ 
cimento carbonático de feições análogas aos eolianitos, porém ainda não litificadas (caso da amostra EPI13R), para ter ideia do tempo de cimentação envolvido na formação dos eolianitos; 3. datar por LOE e ${ }^{14} \mathrm{C}$ sucessões de camadas que representam o substrato dos eolianitos, tais como o "Pós-Barreiras" e os "beach-rocks" (caso do ponto ECE51); 4. datar por LOE e ${ }^{14} \mathrm{C}$ as sucessões acima e abaixo de horizontes calcíferos com gastrópodes continentais interpretados como possíveis paleossolos (caso dos pontos EPI04 e EPI45); 5. datar por ${ }^{14} \mathrm{C}$ concentrações de gastrópodes terrestres em meio a corredores de deflação entre cordões de eolianitos (caso da amostra ECE49Econ), para caracterizar a relação de tempo entre eles.

A amostragem para LOE foi feita em duas alíquotas, uma destinada à leitura de paleodose e outra para a medida de dose anual. A coleta da primeira alíquota foi feita protegida da luz, com uso de tubos opacos, fechados, cravados em porção de depósito livre de retrabalhamento por escorregamento, de preferência na crista da paleoduna. A coleta da segunda alíquota foi feita em saco plástico transparente. Esta segunda alíquota serviu também para ensaios sedimentológicos, como granulometria. As amostras tomadas para petrografía foram embaladas em saco plástico, orientadas quanto a topo e base, e, em seguida, acondicionadas em potes de plástico rígido com tampa.

As amostras foram numeradas em ordem crescente contínua, de $\mathrm{W}$ para $\mathrm{E}$. A primeira letra do código de amostragem faz referência ao tema do projeto (E, de eolianitos). As duas letras seguintes indicam o estado em que foi feita a coleta (PI ou CE), e são seguidas pelo número do ponto ou estação de amostragem, começando por 001; segue-se outra letra, indicativa da litología ou feição geomorfológica (D para duna ativa de orla praial, $\mathrm{P}$ para praia, E para eolianito, $\mathrm{R}$ para rastro linear terrígeno, $\mathrm{X}$ para paleoduna, Y para beach-rock, PB para "Pós-Barreiras" e g para amostras com gastrópodes inteiros); nos casos em que, num mesmo ponto, coletou-se mais de uma amostra, adicionou-se uma letra minúscula, que especifica o horizonte de amostragem (a,b,c, de baixo para cima). A localização das amostras apresenta-se nas figuras 5.1 a 5.4.

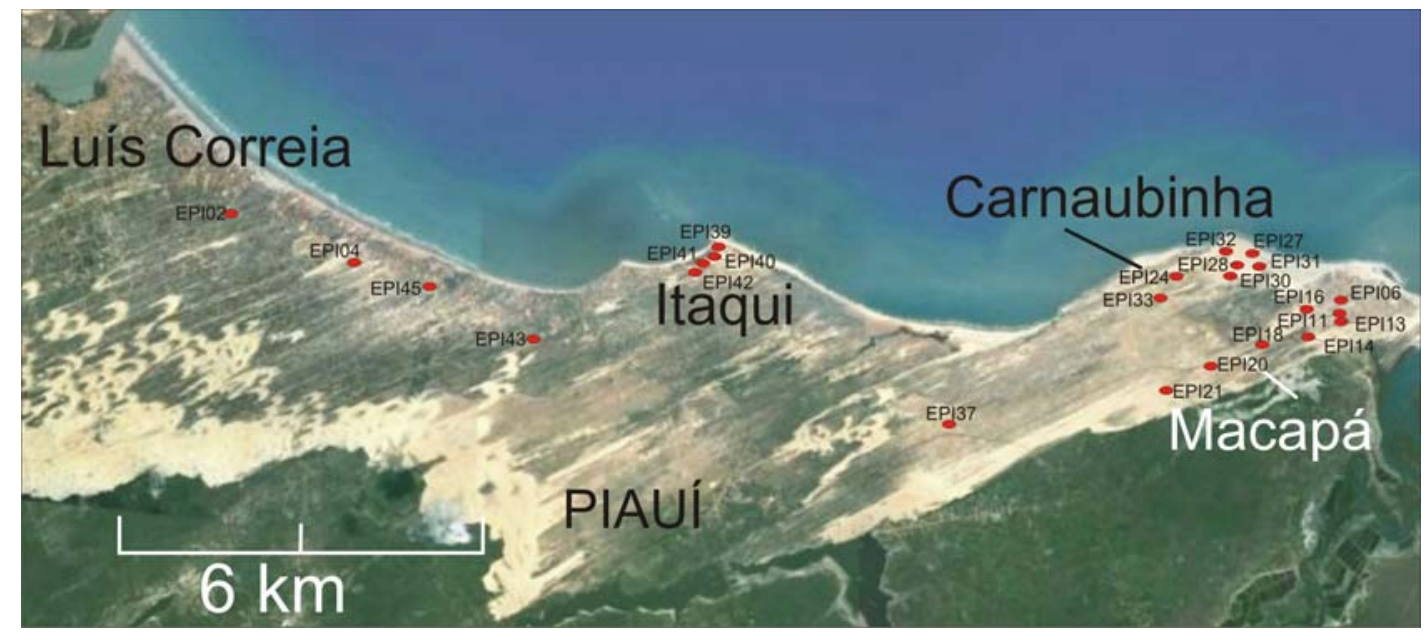

Figura 5.1. Localização de amostras no setor norte, no Estado de Piauí. Para otimizar a visualização, omitiram-se algumas amostras que se encontram dentro de sucessões num mesmo ponto. 


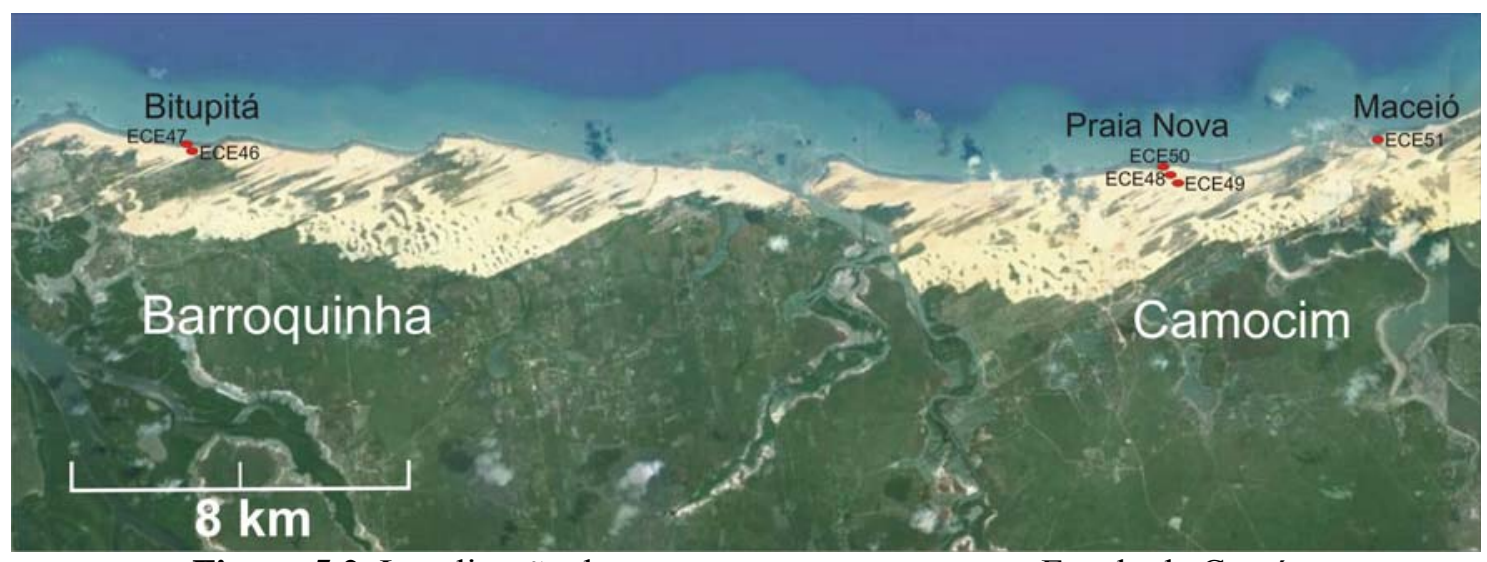

Figura 5.2. Localização de amostras no setor norte, no Estado de Ceará.

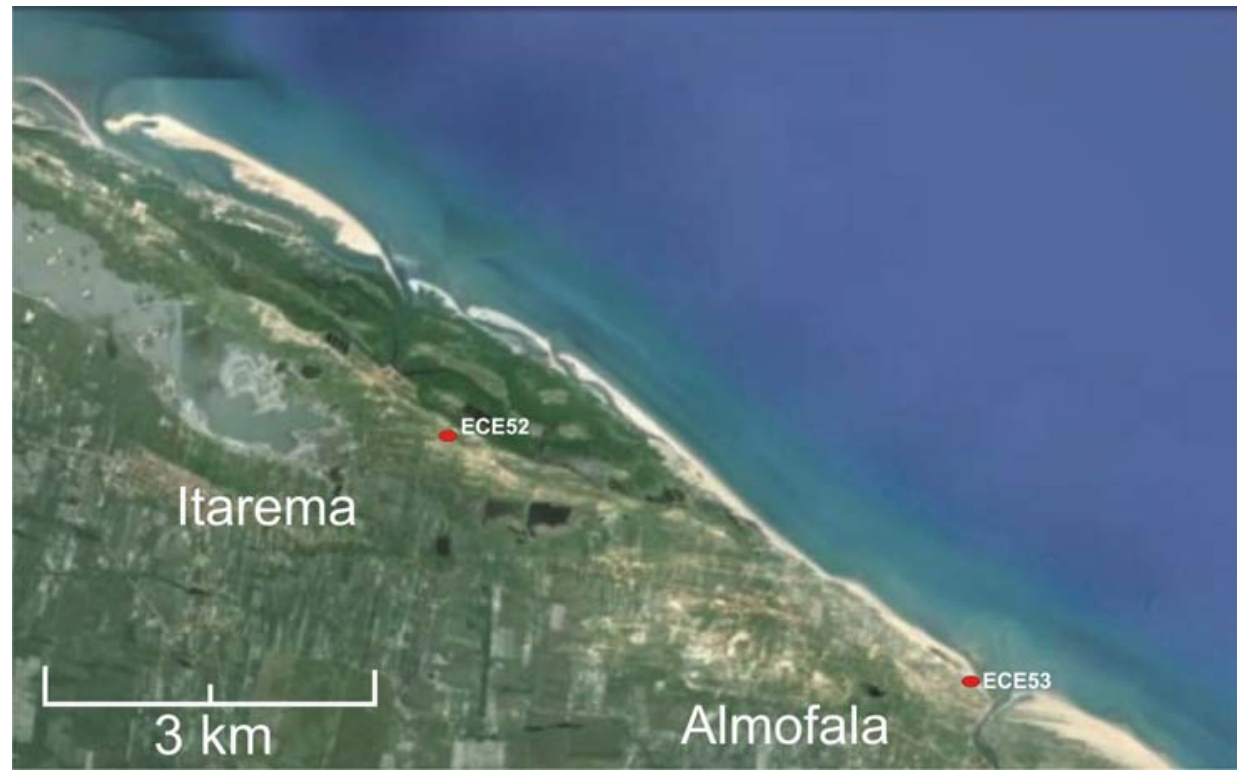

Figura 5.3. Localização de amostras no setor centro.

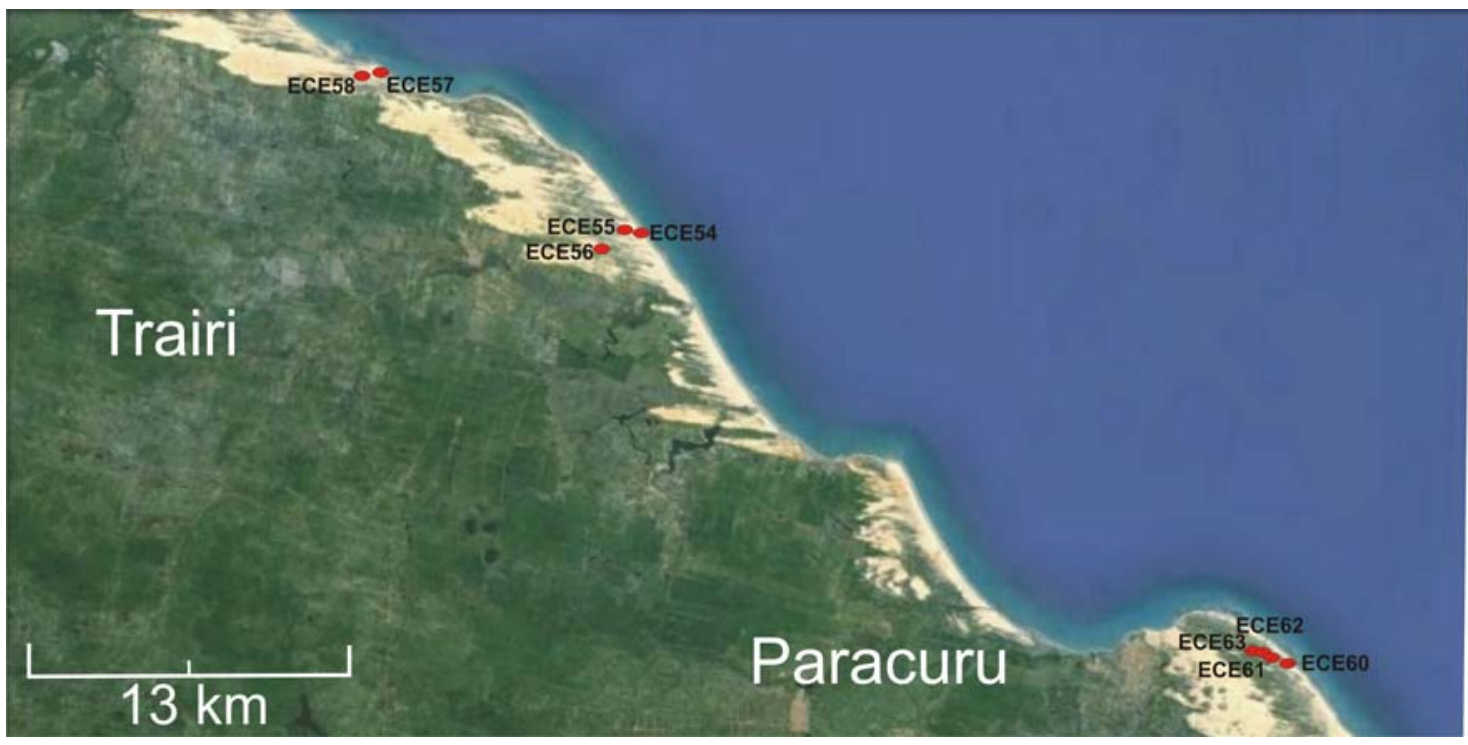

Figura 5.4. Localização de amostras no setor sul. 


\subsection{Atividades de laboratório}

As atividades analíticas e de preparação de amostras foram executadas no Laboratório de Sedimentologia “Armando Márcio Coimbra” (Labsed), no Laboratório de Petrografia Sedimentar (Labpetro), no Laboratório de Microscopia Eletrônica de Varredura (Labmev) e no Laboratório de Espectrometria Gama e Luminescência (Legal),todos do Departamento de Geologia Sedimentar e Ambiental (GSA) do Instituto de Geociências (IGc) da Universidade de São Paulo (USP). Lâminas delgadas foram montadas pela Seção de Laminação do IGc-USP, após impregnação com resina epóxi colorida no Labsed. As amostras das áreas de Carnaubinha (Luís Correia, PI) e de Imboaca e Guajiru (Trairi, CE) foram processadas e analisadas pela estudante Renata Cagliarani, no âmbito de seu projeto de Iniciação Científica, com bolsa do Programa de Recursos Humanos da Petrobras junto ao IGc-USP.

\subsubsection{Granulometria}

A análise granulométrica foi realizada nas 82 amostras, com duas finalidades: refinar a distinção de fácies ou gerações deposicionais reconhecidas no campo; e auxiliar na interpretação de rumos de transporte ou retrabalhamento sedimentar, através do uso tentativo do método de McLaren \& Bowles (1985).

Ela foi feita no equipamento Malvern Masterizer 2000, que calcula matematicamente a granulometria das partículas a partir da difração que elas provocam num feixe de raios laser, conforme a teoria de Mie-Fraunhoffer. O modelo físicomatemático adotado considera partículas dispersas em movimento aleatório, das quais se infere, portanto, um eixo geométrico médio. $\mathrm{O}$ equipamento possui dois tipos de acessório (unidade) de dispersão de amostra: o Hydro, para suspensão líquida de amostras lutáceas, e o Scirocco, para areia seca. Como várias das amostras analisadas apresentavam teor considerável de silte e argila (frequentemente maior que 5\%), devido à impregnação por material argilo-orgânico ferruginoso e/ou por calcimicrita de origem eopedodiagenética, optou-se pelo emprego do acessório Hydro como procedimento padrão em todas as amostras.

\subsubsection{Datações}

\subsubsection{Luminescência}

Princípios do método

A luminescência é a luz emitida por materiais cristalinos ou vítreos, previamente expostos a radiação ionizante, quando submetidos a um agente excitante. Esse agente pode ser o calor (que induz a emissão de termoluminescência ou TL) ou a luz (que induz luminescência opticamente estimulada ou LOE). De acordo com Huntley et al. (1985), os 
sedimentos, quando transportados, sofrem fotoesvaziamento pela exposição à radiação solar, sobrando somente o nível de luminescência residual. Uma vez soterrado, o sedimento é protegido da luz do Sol e a radiação ionizante ambiental começa a acumularse nos vazios de bandas de valência, associados a defeitos cristalinos. Desta maneira, a idade de sedimentação pode ser determinada dividindo-se a dose acumulada desde o soterramento do sedimento pela dose anual de irradiação natural.

A dose acumulada pode ser medida pela estimulação, com luz de um determinado comprimento de onda, de um mineral específico da amostra (usualmente quartzo ou feldspato) e pelo monitoramento da LOE resultante. A dose de radiação natural, medida na unidade Gray $(1 \mathrm{~Gy}=1 \mathrm{~J} / \mathrm{kg})$, é determinada pela comparação entre o sinal da luminescência natural e o sinal obtido por uma exposição controlada no laboratório. A taxa de radiação é resultado da soma da radiação ionizante originada principalmente pelo decaimento radioativo dos elementos ${ }^{232} \mathrm{Th},{ }^{235} \mathrm{U},{ }^{238} \mathrm{U},{ }^{40} \mathrm{~K}$ e ${ }^{87} \mathrm{Rb}$, contidos em certos minerais do sedimento num raio de influência de $30 \mathrm{~cm}$, e da radiação cósmica no local do depósito. Como a energia resultante de cada decaimento, bem como a meia-vida dos radionuclídeos, são bem conhecidas, a taxa de dose de radiação (em Gy/ano) pode ser determinada pela concentração dos radionuclídeos na amostra.

A datação por LOE possui alcance de poucas décadas (Ballarini et al. 2003, Madsen et al. 2005) até cerca de 200 mil anos atrás (Wintle 2008). O limite inferior do método é determinado pelo limite de detecção do sinal LOE. Já para doses acumuladas elevadas, a amostra torna-se saturada e o sinal da LOE para de crescer. Esse valor de saturação varia conforme a amostra, comumente dentro do intervalo entre 100 e 200 Gy (Wintle 2008). A idade máxima alcançada pelo método depende, portanto, além do valor de saturação da amostra, da taxa de radiação natural; quanto menor esta taxa, maior o alcance.

Procedimento aplicado

O método LOE foi aplicado em grãos de quartzo provenientes de 21 amostras arenosas, sendo 17 de eolianitos, uma de fácies areno-conglomerática da base do "PósBarreiras"e três de paleodunas não carbonáticas. A separação e preparação dos grãos com esta finalidade foi realizada, sob luz vermelha, segundo as seguintes etapas: 1. peneiramento, para separação da fração entre 120 e $150 \mu \mathrm{m} ; 2$. tratamento com $\mathrm{H}_{2} \mathrm{O}_{2} 27 \%$ para eliminação de matéria orgânica; 3. ataque com $\mathrm{HCl} 37 \%$ para eliminação de carbonatos; 4. ataque com HF $40 \%$ por 40 minutos, para eliminação do feldspato e da porção externa dos grãos de quartzo afetada pela radiação alfa; 5 . novo tratamento com $\mathrm{HCl}$, para eliminação de compostos residuais relacionados ao ataque de HF; 6. separação de minerais leves por flutuação em solução de metatungstato de lítio $\left(\mathrm{Li}_{6}\left(\mathrm{H}_{2} \mathrm{~W}_{12} \mathrm{O}_{40}\right) \mathrm{H}_{2} \mathrm{O}\right)$, preparada a densidade de $2,75 \mathrm{~g} / \mathrm{cm}^{3} ; 7$. separação entre quartzo e feldspato remanescente, com uso de solução de metatungstato de $\mathrm{Li}$ à densidade de $2,62 \mathrm{~g} / \mathrm{cm}^{3}$.

O procedimento utilizado foi o do protocolo SAR de Murray \&Wintle (2000) e Wintle\& Murray (2006), que é o mais aceito para a determinação da dose de radiação acumulada em grãos de quartzo. Consiste em comparar o sinal LOE natural com o sinal de doses conhecidas (D1 a D4), por interpolação simples. Doses teste (TDI) são aplicadas 
após cada medida LOE, como forma de corrigir a mudança na sensibilidade da amostra. Esses sinais de luminescência foram medidos com o equipamento Riso DA-15 TL/OSL system no Legal, IGc-USP. A fonte beta de ${ }^{90} \mathrm{Sr} /{ }^{90} \mathrm{Y}$ acoplada a esse equipamento forneceu a taxa de dose de 95.9+/-4.1 mGy/s. O estimulo óptico foi feito com LEDs azuis (comprimento de onda $470 \mathrm{~m}$ ) que atingiam as amostras com a intensidade de $31 \mathrm{~mW} / \mathrm{cm}^{2}$. A taxa de aquecimento utilizada foi de $5^{\circ} \mathrm{C} / \mathrm{s}$ e todas as alíquotas foram preparadas com o mesmo volume ( 400 grãos).

$\mathrm{Na}$ medida da taxa de dose anual de radiação por espectrometria gama, utilizou-se um detector de germânio de alta pureza (HPGe), pertencente ao Legal. A contribuição da radiação cósmica na taxa anual foi calculada de acordo com Prescott \&Stephan (1982) e Barbouti \& Rastin (1983), usando-se informações sobre latitude, longitude, altitude e profundidade de coleta, bem como sobre a umidade de cada amostra. A influência deste último parâmetro no amortecimento da absorção de radiação é afetada pela presença de cimento carbonático (Mauz \& Hoffmann, 2014), porém, nas datações realizadas, este fator pôde ser desprezado, em vista do fato de tanto os valores de umidade quanto os conteúdos de cimento serem muito baixos e não afetarem significativamente os resultados finais. Estimou-se o erro total da dose anual de acordo com a lei gaussiana de propagação de erro. As idades são apresentadas em anos antes de 2014, que foi a data de realização dos ensaios.

\subsubsection{2. ${ }^{14} \mathrm{C}$}

Princípios do método

A datação por ${ }^{14} \mathrm{C}$ foi descoberta, no final dos anos 1940, por Willard Frank Libby, que recebeu o prêmio Nobel de Química de1960, pelo desenvolvimento dessa técnica. Ele percebeu que a quantidade de ${ }^{14} \mathrm{C}$ dos tecidos orgânicos mortos diminui logaritmicamente com o passar do tempo. Desse modo, sua quantificação permite estimar o tempo decorrido desde a morte do organismo. Esta técnica é aplicável à madeira, carvão, sedimentos orgânicos, carapaças carbonáticas, ossos com vestígios de colágeno, pelos, e, enfim, a todo material que contenha ${ }^{14} \mathrm{Cde}$ origem biogênica em alguma de suas formas.

A maior parte do carbono presente na atmosfera terrestre é composta de uma mistura de dois isótopos estáveis: $98,9 \%$ de ${ }^{12} \mathrm{C}$ e $1,1 \%$ de ${ }^{13} \mathrm{C}$, com traços de um terceiro, o ${ }^{14} \mathrm{C}$, que é radioativo (Farias 2002). Assim que um organismo morre, ele para de absorver novos átomos de carbono; a relação de ${ }^{14} \mathrm{C}$ por ${ }^{12} \mathrm{C}$ no momento da morte é a mesma que a da atmosfera e dos outros organismos vivos, mas o ${ }^{14} \mathrm{C}$ começa então a decair e não é mais reposto. A meia-vida do ${ }^{14} \mathrm{C}$ é de 5.700 anos. Ao comparar-se a relação entre ${ }^{14} \mathrm{C}$ e ${ }^{12} \mathrm{C}$ na amostra, com a mesma relação na atmosfera de sua época, é possível determinar de modo bastante preciso a idade de um organismo que viveu em tempos passados.

Desde 1977, a espectrometria de aceleração de massa (AMS, na sigla em inglês) tem sido usada para contar diretamente os átomos de ${ }^{14} \mathrm{C}$ numa amostra, em vez de medir a taxa de emissão radioativa (cintilometria) ligada indiretamente à concentração desse 
isótopo. Com esta técnica, pode-se usar amostras de menores dimensões (5-10mg), conseguindo maior precisão e maior alcance máximo (da ordem de $50 \mathrm{ka}$ ).

Inicialmente, assumiu-se que a quantidade de ${ }^{14} \mathrm{C}$ na atmosfera era temporalmente constante, mas sabe-se hoje que alterações no campo magnético da terra ena intensidade da insolação modificaram significativamente esta quantidade ao longo do tempo (Francisco et al. 2011). No entanto, as variações do teor de ${ }^{14} \mathrm{C}$ na atmosfera podem ser conhecidas com precisão através de estudos dendrocronológicos. Um banco de dados baseado nestes estudos permite atualmente o cálculo das datas calibradas até 18.000 anos convencionais AP (antes do presente, isto é, 1950), com a ajuda de programas de calibração como CALIB 6.0 (Reimer et al. 2009). Para idades maiores, a calibração é feita em camadas de crescimento de aragonita de bioconstruções marinhas (corais).

Procedimento aplicado

A datação por ${ }^{14} \mathrm{C}$ foi feita em 17 amostras (entre 0,5 e $5 \mathrm{mg}$ de cada), das quais foram datados os bioclastos (principalmente algas indeterminadas mas também moluscos), sendo em quatro delas datadas também os cimentos carbonáticos; tanto as algas como os cimentos foram analisadas com difratometria de Raios-X (DRX), para conhecer sua composição mineralógica, o que ajudou a deduzir que as algas eram rodofíceas (as clorofícias são aragoníticas). A finalidade de datar bioclastos e cimento foi obter, respectivamente, as idades máxima e mínima de deposição. A premissa foi a de que o cimento é formado por dissolução e reprecipitação do carbonato dos próprios bioclastos, porém rejuvenescido por carbono da matéria orgânica de solos ou paleossolos estabelecidos sobre o depósito.

As amostras foram separadas à lupa estereoscópica, sem contato manual, com uso de pinças e instrumentos odontológicos, no Labpetro. Como se observou ao microscópio, após a coleta, que cada bioclasto era rodeado por uma fina película de cimento, e com o intuito de evitar a contaminação por este material, foi preciso fazer um tratamento químico prévio. Esse tratamento consistiu no ataque dos bioclastos com $\mathrm{HCl} 5 \%$ durante $30 \mathrm{~s}$, seguido de lavagem com água destilada e secagem em estufa a $45^{\circ} \mathrm{C}$. As alíquotas assim processadas foram enviadas ao Poznan Radiocarbon Laboratory da Foundation of the A. Mickiewicz University, em Poznań, Polônia, onde se realizaram as datações por AMS. As idades de radiocarbono foram normalizadas para um $\delta^{13} \mathrm{C}$ de $-25 \%$ VPDB e apresentadas em anos calibrados (a cal AP) (2 $\sigma$ ), usando-se para isso o programa CALIB 6,0 e a curva Intcal09 (Reimer et al. 2009).

\subsubsection{Dosagem de carbonato}

O teor em massa total de carbonato de cálcio de todas as amostras foi quantificado por ataque com $\mathrm{HCl}$ (ácido clorídrico) $10 \%$ a quente, conforme método descrito por Melo et al. (2004). Dados sobre teor de carbonato foram inferidos também da análise petrográfica das amostras consolidadas, neste caso com distinção entre bioclastos e cimento, feita por estimativa visual em área. A finalidade da quantificação de carbonato foi 
verificar a influência da composição original do sedimento (teor de bioclastos) na formação dos eolianitos e auxiliar na distinção de petrofácies.

O teor em massa de carbonato foi utilizado ainda como critério quantitativo para distinguir as amostras, e as fácies por elas representadas, correspondentes a eolianitos. Com base na comparação entre o que se avaliou no campo como eolianito e os teores de carbonato neles encontrados em laboratório, foram redefinidos como eolianitos, nesta dissertação, os depósitos considerados eólicos, litificados ou semi-consolidados, com teor em massa de carbonato $\geq 5 \%$. Os critérios práticos campo para sua distinção são apresentados nos resultados do Artigo 1.

\subsubsection{Petrografia}

A análise petrográfica, ao microscópio de luz polarizada, de depósitos consolidados foi aplicada não só aos eolianitos, mas também a rochas adjacentes ou subjacentes a eles (e.g. Formação Barreiras, "Pós-Barreiras" e beach-rocks) cujo estudo visou proporcionar contexto à interpretação faciológica. Ela teve como finalidade a confirmação de fácies deposicionais e seu refinamento via subdivisão em petrofácies; a análise de petrofácies visou à individualização de litologias e características texturais e diagenéticas que diferenciem processos ou condições de diagênese precoce, como, por exemplo, meteóricos vadosos versus freáticos. A definição de petrofácies adotada nesta dissertação é a de Gesicki (2007): "agrupamento de rochas sedimentares que possuam atributos similares de textura, petrotrama e mineralogia, resultantes da combinação e sobreposição de aspectos deposicionais por aspectos diagenéticos". O uso do termo constitui uma variante da própria definição de fácies ou litofácies (sensu Walker 1980). Assim, as petrofácies representam um conjunto de características físicas e químicas de um depósito sedimentar litificado ou semi-consolidado, analisáveis em escala microscópica, o qual se supõe ser produto de processos deposicionais e diagenéticos.

As lâminas delgadas foram confeccionadas a partir de amostras impregnadas a vácuo com resina epóxi colorida (azul), de modo a permitir distinção entre poros verdadeiros e poros artefatuais (induzidos durante a laminação). As lâminas foram feitas sem lamínula para permitir testes de mineralogia de carbonato via colorimetria com solução ácida e paraanálises ao Microscópio Eletrônico de Varredura (MEV) com Espectrômetro de Energia Dispersiva (EED). A colorimetria visou à distinção entre calcita/aragonita e calcita magnesiana bem como ao reconhecimento de eventuais dolomita e carbonatos ferrosos. Como reagente para este teste de cor, utilizou-se a mistura de $250 \mathrm{ml}$ de ácido clorídrico $(\mathrm{HCl})$ diluído $(1,5 \%)$ com 2,0 g de ferricianeto de potássio $\left(\mathrm{K}_{3} \mathrm{Fe}(\mathrm{CN})_{6}\right)$ e 0,3 gde alizarina vermelha $\left(\mathrm{C}_{14} \mathrm{H}_{7} \mathrm{O}_{7} \mathrm{SNa}\right)$.

No estudo petrográfico, os aspectos descritos englobaram: reconhecimento e quantificação dos componentestexturais maiores (arcabouço, matriz e cimento); identificação do componente de sustentação da rocha (se arcabouço, matriz ou cimento); quantificação da fração terrígena e intrabacinal do arcabouço, com identificação das respectivas composições mineralógicas; caracterização do arcabouço quanto à trama (segregação granular, gradação e imbricação), com uso do índice de empacotamento Ipk de 
Kahn (1956); avaliação da granulometria modal das frações terrígena e intrabacinal, usando-se a escala de Wentworth (1922); estimativa do desvio-padrão de cada fração de acordo com a escala gráfica de Pettijohn et al. (1973); classificação nominal do grau de seleção granulométrica segundo a proposta de Folk (1965), com base no desvio padrão estimado; estimativa da esfericidade de grãos terrígenos e de arredondamento do quartzo segundo a escala gráfica de Powers (1953); descrição da mineralogia e textura do cimento, com indicação de possíveis gerações; descrição de tipos de contato intergranular e de feições de quebra ou deformação de grãos, e avaliação de seu significado enquanto indícios de compactação química e mecânica, respectivamente; avaliação da ordem cronológica relativa entre processos de cimentação e compactação;caracterização da porosidade conforme Choquette \& Pray (1970); classificação da rocha segundo Dott (1964) e Folk (1968), no caso das terrígenas, ou segundo nomemclatura mista entre a de Dott (1964) e as de Folk $(1959,1962)$ e Dunham (1962) no caso das rochas mistas terrígeno-bioclásticas; e classificação de petrofácies. O processo de descrição petrográfica foi acompanhado do registro em fotomicrografias através da câmera Leica $D M 750 P$ e do analisador de imagens digitais LAS (Leica Application Suite). Os estudos petrográficos serviram também para a seleção prévia das amostras e microfeições promissoras para o detalhamento químicotextural ao equipamento de MEV-EED.

\subsubsection{Microscopia eletrônica de varredura}

A análise por MEV-EED de duas amostras de eolianitos teve como objetivo detalhar a micromorfologia e composição dos cimentos e os sinais de abrasão e corrosão dos bioclastos. Para a análise micromorfológica, utilizou-se o detector de elétrons secundários (secondary eletrons ou SE), que capta preferencialmente os elétrons oriundos da própria amostra, ejetados pela colisão do feixe eletrônico incidente. A energia destes elétrons é controlada pela distância percorrida e a imagem produzida pode assim ser considerada um reflexo da topografia da amostra. Para o exame da variação da composição química, utilizou-se o detector de elétrons retroespalhados (back-scattered eletrons ou BSE) do próprio feixe, cuja energia se relaciona com o peso atômico médio da superfície da amostra. Para a microanálise química pontual, utilizou-se o EED, que permite quantificar os elementos presentes em seções planas num raio de $2 \mu \mathrm{m}$ ou maior.

\subsection{Tratamento gráfico-estatístico dos dados}

\subsubsection{Resultados de campo}

Histogramas circulares (rosas de frequências) foram utilizados para representar medidas de rumo de mergulho de superfícies de truncamento e de planos de estratificação cruzada por área. Eles foram obtidos através do emprego do programa Stereonet, o qual permitiu calcular o vetor médio e intervalo angular de confiança ("conf.") para uma 
probabilidade de 95\%. A finalidade foi identificar o padrão da distribuição (unimodal, bimodal, bipolar etc) e a orientação das modas. Na subdivisão interna dos histogramas em circunferências concêntricas, representativas das frequências de ocorrência de cada classe de azimutes, utilizaram-se intervalos de 5\%. A circunferência externa equivale a $20 \%$. Calculou-se também o ângulo médio de mergulho. De posse dos dados de padrão de distribuição e ângulos de mergulho, e de informações sobre o vento efetivo por região, tentou-se inferir a fácies ou elemento morfológico correspondente a cada conjunto de medidas.

\subsubsection{Resultados analíticos laboratoriais}

Ao término das análises laboratoriais de granulometria, quantificação de carbonato, mineralogia e petrografia óptica, foram executados balanços de massa (no caso do teor de carbonato por ataque ácido) ou de volume (nos demais), em valores de distribuição porcentual.

Os resultados de distribuição granulométrica, agrupados em intervalos de 0,125, foram convertidos em estatísticas (diâmetro médio, desvio padrão, assimetria e curtose), calculados pelo método analítico dos momentos de Pearson. Para o cálculo do diâmetro médio, foram computados somente os valores referentes aos sedimentos arenosos, pois no tipo de depósito eólico estudado a quantidade de material pelítico, incluindo micrita, é reflexo da diagênese e pedogênese (Giannini et al. 2007, Sawakuchi et al. 2009), e, portanto, não reflete os processos deposicionais. A classificação nominal do grau de seleção, de acordo com o valor de desvio padrão, foi feita segundo a proposta de Folk (1965).

Dois tipos de testes gráfico-estatísticos foram aplicados aos resultados granulométricos, mineralógicos e petrográficos. O primeiro foi a construção de diagramas de dispersão no software Origin 8.0 desses resultados combinados dois a dois entre si ou em função de outros critérios quantificáveis como idade e distância à costa. O objetivo foi identificar nuvens de pontos com possível significado faciológico ou cronológico e avaliar a correlação linear (r) entre as variáveis, com nível de confiança estatístico (p ou erro I) calculado através do teste $t$ de Student. $O$ segundo foi a caracterização da dispersão de agrupamentos de amostras, estabelecidos quanto aos mesmos critérios, através da construção de diagramas em caixa (boxplot). Neste tipo de gráfico (Figura 5.5), a caixa representa o intervalo interquartis e a linha horizontal no seu interior, a mediana; as linhas verticais (bigodes) unem o valor máximo e mínimo observados, dentro de 1,5 vezes o intervalo interquartil; e os dados anômalos (outliers), em asterisco, representam valores observados fora dos bigodes. Para a confecção destes diagramas, foi usado o software Minitab 17. 


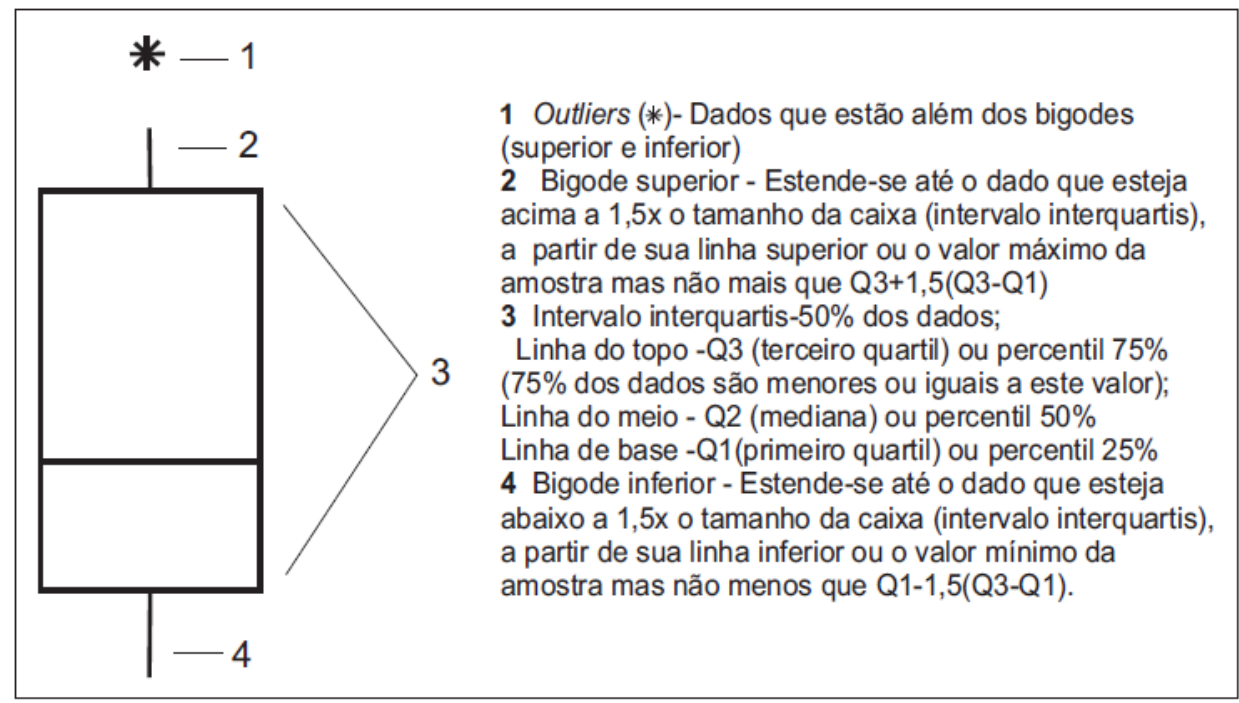

Figura 5.5. Esquema de um diagrama em caixa (boxplot), ferramenta de estatística descritiva utilizado neste trabalho (extraído de Menezes 2009).

\subsection{Elaboração de mapas e seções}

Os mapas de unidades sedimentares e respectivas seções geológicas esquemáticas, para cada área detalhada de ocorrência de eolianitos, foram elaborados com base no conjunto de dados obtidos ao longo de todo o trabalho e são apresentados no Artigo 1, no item 6.1.3.

Nos mapas, procurou-se representar a distribuição espacial das feições morfológicas dos sistemas deposicionais costeiros ativos, tanto eólicos quanto subaquosos, e dos corpos de eolianito. As seções geológicas representam de modo esquemático, ilustradas por fotografias de campo, a morfologia geral do sistema praia-duna e a topografia e atitudes de estratificações dos eolianitos, incluindo as rosetas de azimute de mergulho.

Para a elaboração dos mapas e seções, utilizou-se o software Corel Draw, versão X3.

\section{Artigo 1: Morfologia, fácies deposicionais e cronologia dos eolianitos quaternários do litoral do Piauí e oeste do Ceará}

\subsection{Resultados}

\subsubsection{Subdivisão morfológica do sistema eólico costeiro e os cordões de eolianitos}

Com base nos rumos de vento efetivos na formação das dunas e na distribuição e desenvolvimento de elementos morfológicos eólicos, optou-se por subdividir a área de 
estudo em três setores: norte, centro e sul (Figura 6.1). Assim, o setor norte compreende as dunas e eolianitos do Piauí e extremo oeste do Ceará (Barroquinha e Camocim); o setor centro abrange os de Itarema; e o setor sul, os de Trairi e os de Paracuru.

\subsubsection{Setornorte}

O setor norte subdivide-se em dois trechos, que têm em comum a orientação para SW do vento efetivo e do avanço dos campos de dunas, mas com contrastes na orientação da costa e, por consequência, na extensão do sistema eólico. $O$ trecho contido no litoral piauiense, entre a cidade de Luís Correia e Macapá, é formado por três arcos praiais principais de orientação WNW, Coqueiro, Carnaubinha-Maramar e Macapá, aos quais se associam três campos de dunas transgressivos, lateralmente coalescidos entre si (Figura 6.1). A quase perpendicularidade entre o vento efetivo e a linha de costa faz com que os campos de dunas avancem por grande distância (até cerca de8 $\mathrm{km}$ ) ao interior, e favorece a criação de amplas planícies de deflação. No trecho do litoral extremo oeste cearense, entre Bitupitá e Jericoacoara, a orientação dominante da costa passa a WSW, o que decresce a cerca de $30^{\circ}$ o ângulo entre os campos de dunas e as praias. A areia eólica passa consequentemente a distribuir-se numa distância menor (cerca de $4 \mathrm{~km}$ ) no rumo do vento e as feições francamente deposicionais tornam-se mais importantes em relação às deflacionares, em comparação com a costa do Piaú.

Neste setor, as praias têm o domínio de morfodinâmica costeira dissipativa, com exceção da praia Nova, em Camocim (Figura 10), que é intermediária. A associação de elementos praia-duna (sensu Giannini et al. 2014, cf. item 2.3) tem largura de 200m a 1,5 $\mathrm{km}$. Nela, as dunas frontais não se encontram bem configuradas, substituindo-se por terraços de nebkhas baixos (menos de 0,5 m de altura), exceto na praia de Carnaubinha, onde o campo de nebkhas ocorre ao interior de duna frontal assimétrica com lado mais íngreme voltado para o mar. A associação de elementos de deflação apresenta largura variável entre 3 e $7 \mathrm{~km}$, apresentando rastros lineares, retrocordões e junto à praia do Coqueiro, dunas parabólicas. A associação de elementos de campos de dunas livres, com até $6 \mathrm{~km}$ de largura, é dominada por dunas barcanas, cadeias barcanoides e lobos deposicionais, estes últimos pouco definidos. 


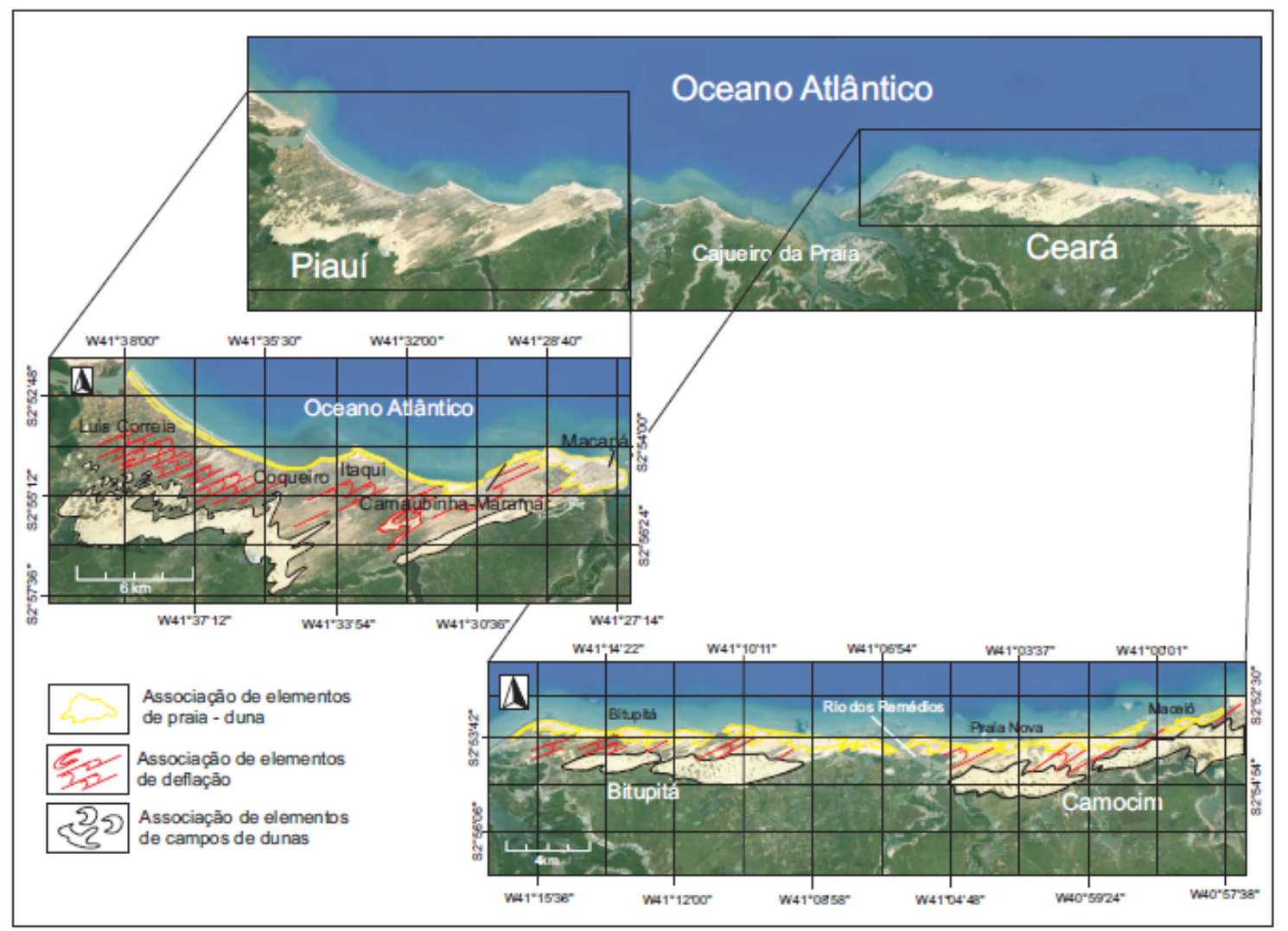

Figura 6.1. Associações de elementos morfológicos do sistema eólico costeiro ativo, no setor norte da área de estudo (Piauí e extremo oeste cearense).

Os eolianitos do setor norte ocorrem em meio às zonas deflacionárias, na forma de cordões com cristas descontínuas, cujas alturas variam de 1 a $7 \mathrm{~m}$, chegando, porém a aproximadamente $20 \mathrm{~m}$ na área de Bitupitá (Figura 6.2). Estes cordões apresentam orientação paralela ao vento efetivo (SW) e aos rastros lineares residuais dos campos de dunas ativos, pelos quais são parcialmente cobertos.

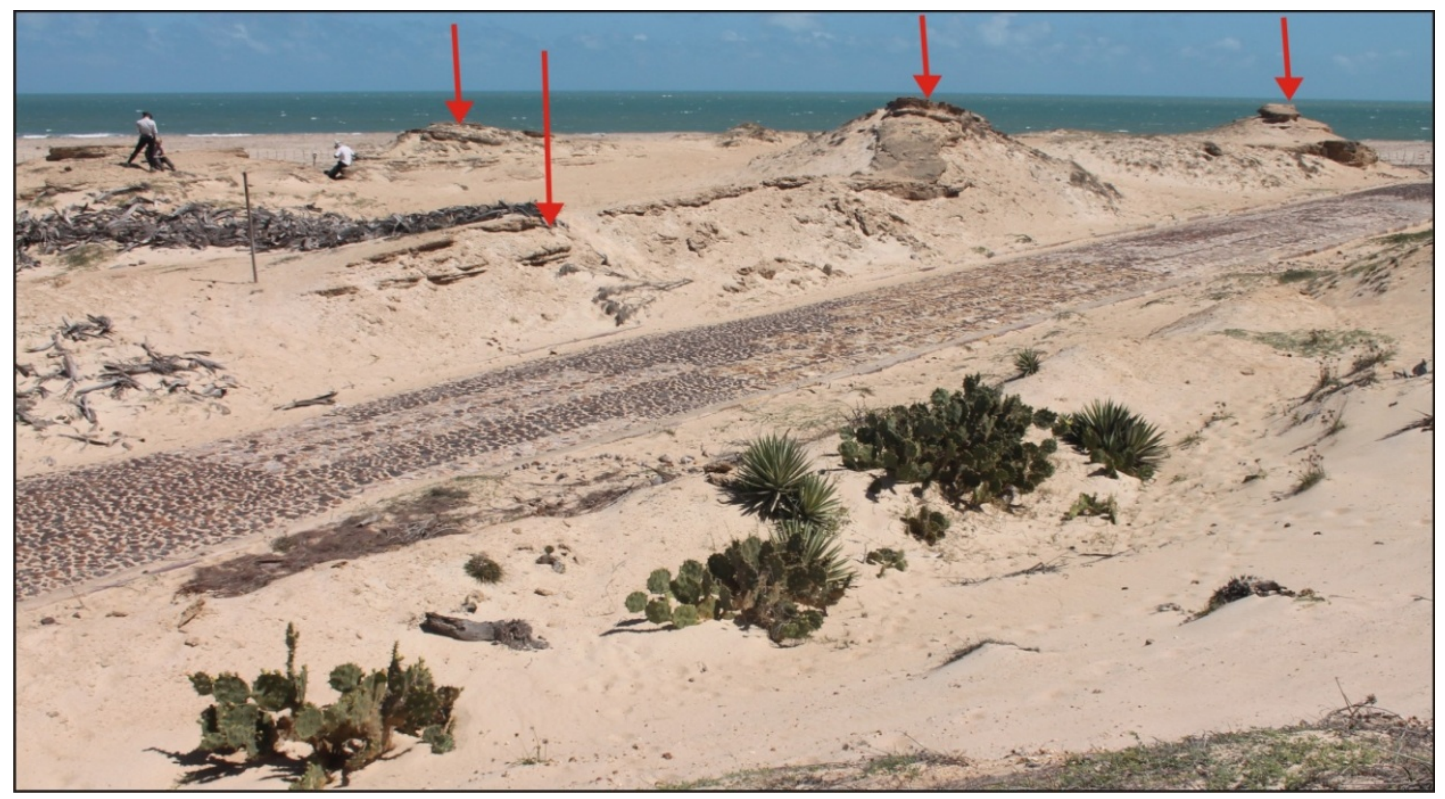

Figura 6.2. Cordões de eolianitos em formas de cristas descontínuas na área de Itaqui. 


\subsubsection{Setor centro}

O setor centro estende-se desde o município de Itarema até o extremo norte do município de Trairi, passando por Almofala. A direção geral dominante da linha de costa no setor é WNW, com ângulo de cerca de $35^{\circ}$ em relação à direção de avanço do sistema eólico costeiro, o qual se mantém com extensão abaixo de $5 \mathrm{~km}$. Este setor é separado do setor morte por um trecho, entre Jericoacoara e Itarema, em que o sistema eólico é pouco desenvolvido e onde a linha de costa se torna convexa para o mar, variando de WSW, a W, a ESE, a E (Figura 6.3). A ausência de campos de dunas ativos neste trecho pode estar relacionada ao consumo do estoque de areia costeira com a formação de um esporão a $\mathrm{W}$ de Itarema, na forma de ilha-barreira com crescimento via deriva litorânea para NW. O desenvolvimento progressivo deste esporão, desde 1984, é evidente no programa Timelapse (2015) e deve estar ligado, por sua vez, à própria mudança local na orientação da linha de costa.

O sistema eólico costeiro volta gradualmente a tornar-se expressivo deste esporão para E, só que com vento efetivo quase E-W (azimute 280), o que se mantém pelo menos até Canoa Quebrada.

A área de Itarema situa-se junto à raiz (barlamar) do esporão e, portanto, ainda reflete sua influência no pouco desenvolvimento do sistema eólico, o qual apresenta aí somente duas associações de feições morfológicas eólicas: a praia-duna, com largura média de $250 \mathrm{~m}$, composta por lençóis de areia; e a planície de deflação, com largura total de $4500 \mathrm{~m}$, evidenciada pela presença de rastros lineares, inclusive inativos, os quais aparecem levemente apagados na imagem de satélite, especialmente em uma área brejosa alongada subparalelamente à costa e à laguna em formação atrás do esporão. Outra laguna com mesma orientação ocorre ainda ao interior da área brejosa, o que permite sugerir que o desenvolvimento de pares esporão-laguna é recorrente na área e constitui mecanismo de progradação (Figura 6.3). Assim, a ausência de campo de dunas ativo em Itarema pode-se atribuir a esta progradação e à sucessiva interrupção do transporte eólico por lagunas costeiras.

Já a área de Almofala apresenta associação praia-duna, com largura média de $30 \mathrm{~m}$, zona de deflação, com 350 m, e um campo de dunas inativo, de cerca de $2 \mathrm{~km}$ de extensão. Estes valores são apenas estimados e a estabilização do campo de dunas pode ter sido artificial, já que a ocupação antrópica apagou parte da sua morfologia original (Figura 6.3). 


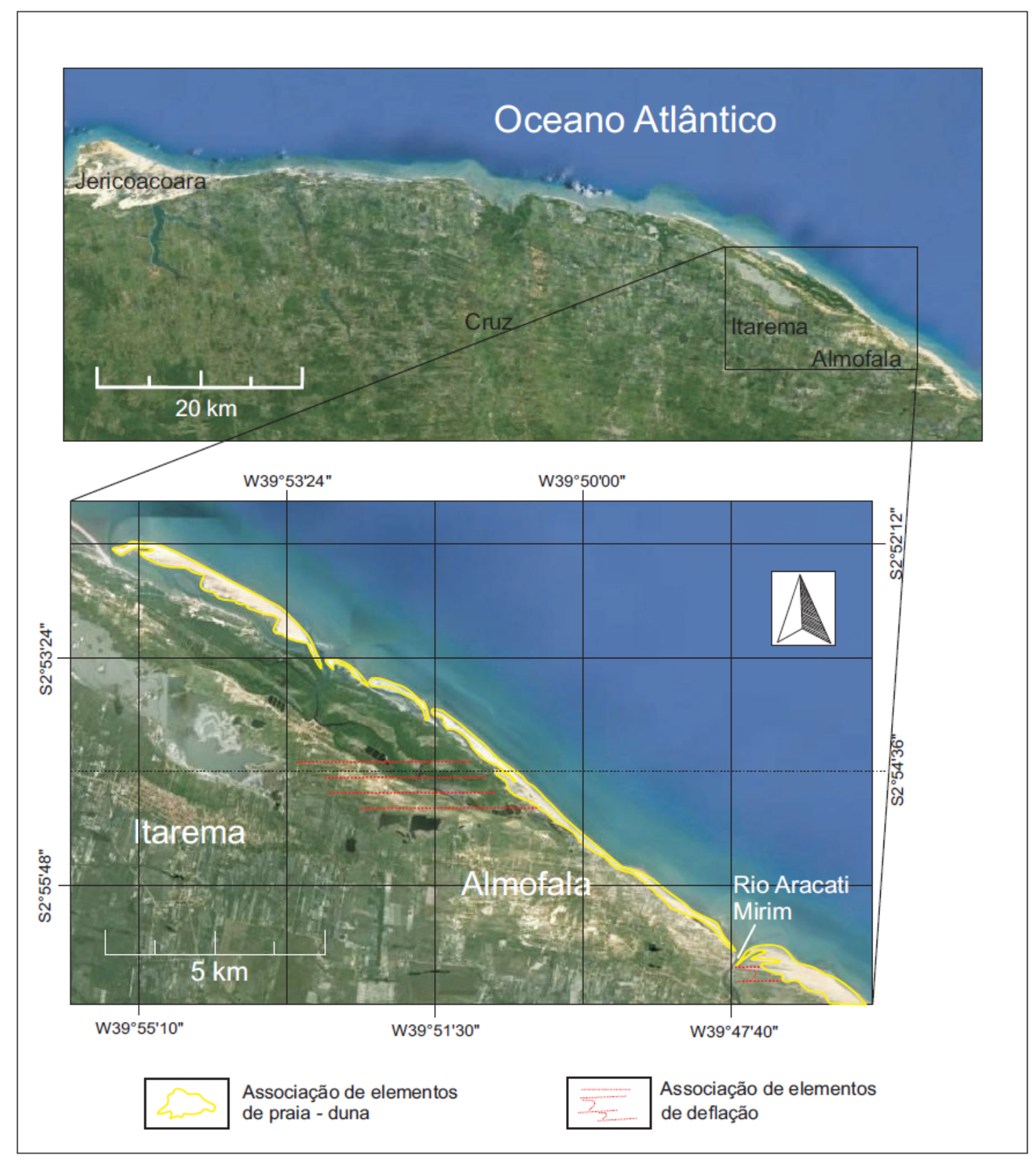

Figura 6.3. Associações de elementos morfológicos do sistema eólico ativo nosetor centro (Itarema e Almofala, município de Itarema, CE). Em Itarema, a progradação através de pares esporãolaguna faz com que o sistema eólico seja sucessivamente abandonado, daí a presença de associações praia-duna e planície de deflação inativas ao interior da área brejosa. Em Almofala, a ausência de associação de campos de dunas ativa pode decorrer da ocupação antrópica.

Os corpos de eolianitos de Itarema encontram-se distantes cerca de $3 \mathrm{~km}$ da praia e apresentam aproximadamente $3 \mathrm{~m}$ de altura. Já em Almofala, foram visitados eolianitos junto à extremidade leste da praia homônima, que é dissipativa e delimitada a leste pela desembocadura do rio Aracati Mirim, de cerca de $80 \mathrm{~m}$ de largura. Ela apresenta terraço sub-horizontal amplo (várias centenas de metros) de variação de maré, ladeado ao interior por face praial íngreme (mergulho de $13^{\circ}$ para o mar) ao pé da duna frontal incipiente. Esta 
duna cobre parcialmente, na forma de rampa de $0,6 \mathrm{~m}$ de altura e cordão assimétrico de até $0,8 \mathrm{~m}$, as falésias vivas de eolianitos com até $7 \mathrm{~m}$ de altura (Figura 6.4).

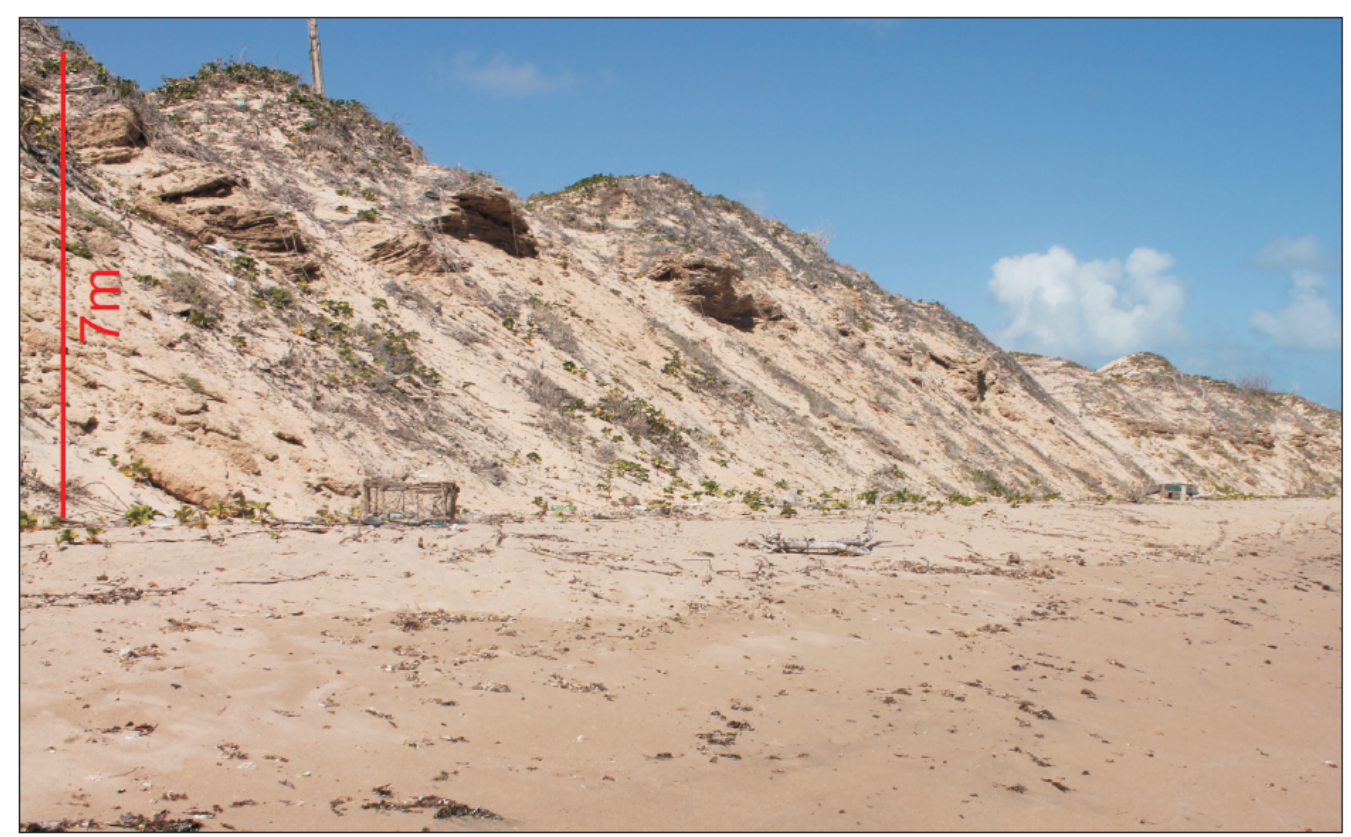

Figura 6.4. Eolianitos cortados pela linha de costa em erosão na área de Almofala.

\subsubsection{Setor sul}

O setor sul compreende as áreas de Trairi e Paracuru, formada por três arcos praiais principais, Imboaca, Guajiru e Piriquara, aos quais se associam campos de dunas transgressivos com avanço para W (azimute 280). A orientação dominante da costa passa a NW, e o ângulo relativo do vento efetivo no avanço das dunas aumenta para até aproximadamente $45^{\circ}$. A elevação deste ângulo faz com que os campos de dunas avancem por maior distância (até cerca de $7 \mathrm{~km}$ ) ao interior, favorecendo também a criação de amplas planícies de deflação (Figura 6.5). 


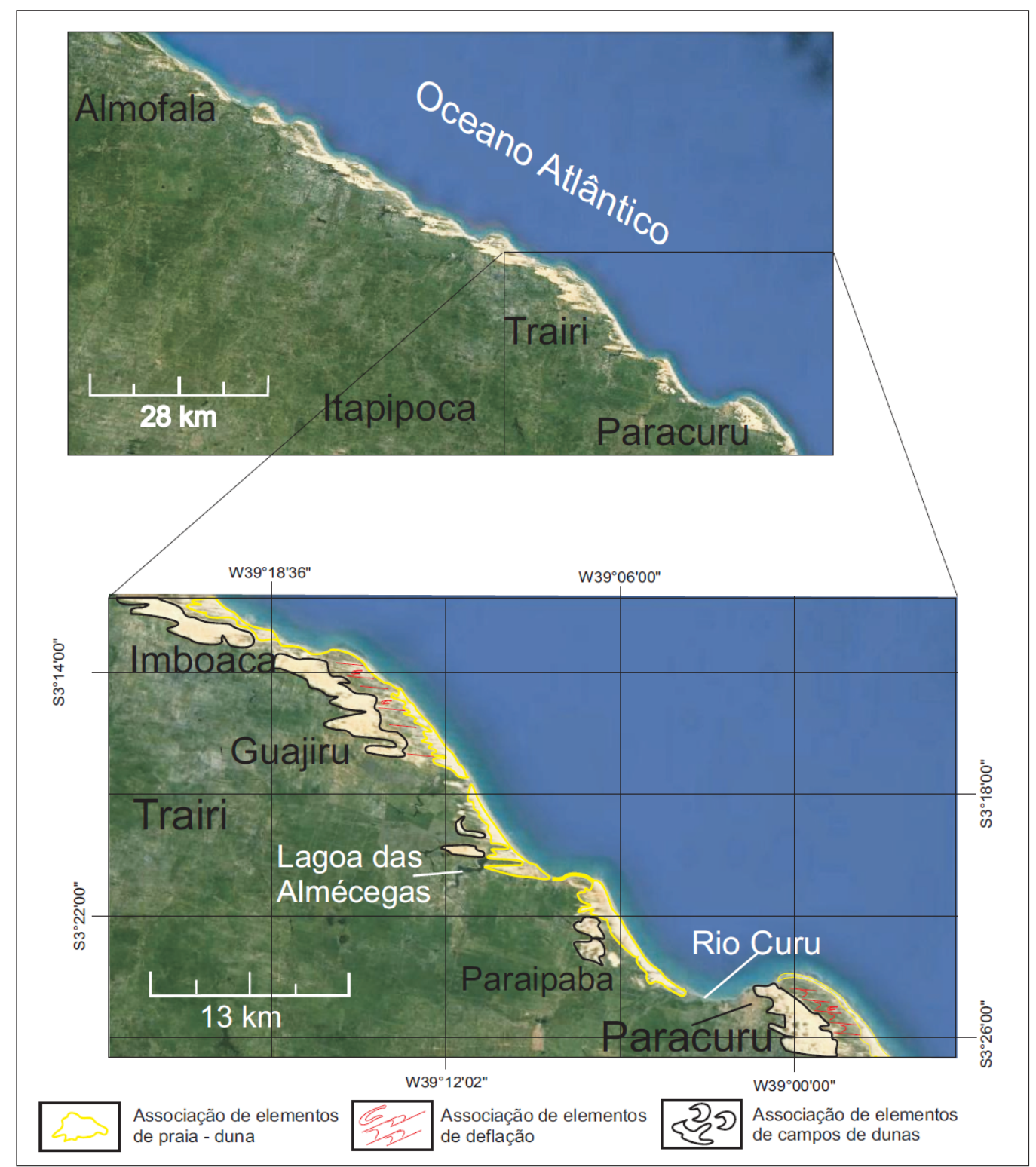

Figura 6.5. Associações de elementos morfológicos no sistema eólico ativo do setor sul (abrangen do Imboaca e Guajiru, município de Trairi, e Piriquara, município de Paracuru).

A associação de elementos praia-duna tem $1200 \mathrm{~m}$ de largura, com presença de dunas frontais mal configuradas e lençóis de areia; a associação de elementos de deflação, com $5 \mathrm{~km}$ de extensão média, apresenta rastros lineares e retrocordões, e a associação de elementos de campo de dunas, com largura média de $4 \mathrm{~km}$, a NW, passando a $7 \mathrm{~km}$, a SE, é dominada por cadeias barcanoides.

Os eolianitos visitados do setor sul foram os adjacentes às praias de Imboaca e Guajiru, no município de Trairi, e de Piriquara, no município de Paracuru. As praias de Imboaca e Guajiru apresentam morfodinâmica intermediária-dissipativa e a de Piriquara, dissipativa. A duna frontal incipiente está presente nas áreas menos modificadas pela ocupação (Imboaca e Piriquara). Seguem-se ao interior rastros lineares residuais orientados para NW; os cordões de eolianitos ocorrem no meio e paralelos a estes rastros, em afloramentos de até $15 \mathrm{~m}$ de altura e séries de estratificações com espessuras desde 0,1 até $2 \mathrm{~m}$. 


\subsubsection{Datações}

Nas 30 amostras destinadas a geocronologia, realizou-se um total de 42 datações, sendo 21 por LOE e 21 por ${ }^{14} \mathrm{C}$ AMS (17 de bioclastos e quatro de cimento carbonático). Foram feitas 33 datações em eolianitos (subitem 6.1.2.1) e nove em fácies associadas (6.1.2.2).

\subsubsection{Eolianitos}

Os resultados das datações em eolianito, com informações sobre a fácies morfológica atual em meio a qual ocorrem, localização e método de datação encontram-se na Tabela 1 .

Tabela 1. Relação de idades das amostras de eolianitos.As datações ${ }^{14} \mathrm{C}$ destacadas com cor (código "cim") referem-se a cimento carbonático.

\begin{tabular}{|c|c|c|c|c|c|c|c|c|}
\hline AMOSTRA & $\begin{array}{c}\text { FÁCIES } \\
\text { MORFOLÓGICA } \\
\text { DE } \\
\text { OCORRÊNCIA } \\
\end{array}$ & $\begin{array}{l}\text { SETOR/ÁREA } \\
\text { (MUNICÍPIO) }\end{array}$ & $\begin{array}{c}\text { IDADE }{ }^{14} \mathrm{C} \text { (anos } \\
\text { AP) }\end{array}$ & $\begin{array}{c}\text { TIPO DE } \\
\text { MATERIAL } \\
\text { DATADO POR } \\
\text { AMS }\end{array}$ & $\begin{array}{l}\text { IDADE LOE } \\
\text { (anos) }\end{array}$ & $\begin{array}{c}\text { ERRO } \\
\text { LOE } \\
\text { (anos) }\end{array}$ & $\begin{array}{l}\text { TAXA } \\
\text { DE } \\
\text { DOSE } \\
\text { (Gy) }\end{array}$ & $\begin{array}{l}\text { ERRO TAXA } \\
\text { DE DOSE }\end{array}$ \\
\hline EPI06 & $\begin{array}{c}\text { Planície de } \\
\text { deflação }\end{array}$ & \multirow{6}{*}{$\begin{array}{l}\text { NORTE/MACAPÁ } \\
\text { (LUÍS CORREIA) }\end{array}$} & & & 1048 & 106 & 0,797 & 0,058 \\
\hline EPI11E & $\begin{array}{l}\text { Planície de } \\
\text { deflação }\end{array}$ & & $1294-1360$ & Algas & 950 & 81 & 0,62 & 0,027 \\
\hline EPI14Ec & $\begin{array}{l}\text { Planície de } \\
\text { deflação }\end{array}$ & & & & 910 & 84 & 0,607 & 0,034 \\
\hline EPI16Eb & $\begin{array}{l}\text { Planície de } \\
\text { deflação }\end{array}$ & & & & 812 & 69 & 0,714 & 0,022 \\
\hline EPI16Ec & $\begin{array}{l}\text { Planície de } \\
\text { deflação }\end{array}$ & & & & 862 & 95 & 0,59 & 0,51 \\
\hline EPI21E & $\begin{array}{l}\text { Planície de } \\
\text { deflação }\end{array}$ & & $2235-2304$ & Algas & 652 & 99 & 0,819 & 0,081 \\
\hline EPI24E & $\begin{array}{c}\text { Planície de } \\
\text { deflação }\end{array}$ & \multirow{2}{*}{$\begin{array}{c}\text { NORTE/CARNAUBINHA- } \\
\text { MARAMAR } \\
\text { (LUÍS CORREIA) }\end{array}$} & $3056-3209$ & Moluscos e algas & 2984 & 271 & 3,28 & 0,127 \\
\hline EPI31E & $\begin{array}{c}\text { Planície de } \\
\text { deflação }\end{array}$ & & $2180-2240$ & Algas & 1226 & 133 & 0,68 & 0,057 \\
\hline EPI39E & $\begin{array}{c}\text { Planície de } \\
\text { deflação }\end{array}$ & \multirow{3}{*}{$\begin{array}{l}\text { NORTE/ITAQUI } \\
\text { (LUÍS CORREIA) }\end{array}$} & & & 1517 & 179 & 2,11 & 0,195 \\
\hline EPI40E & $\begin{array}{c}\text { Planície de } \\
\text { deflação }\end{array}$ & & $2157-2276$ & Algas & 4907 & 444 & 3,522 & 0,156 \\
\hline EPI41E & $\begin{array}{l}\text { Planície de } \\
\text { deflação }\end{array}$ & & & & 1506 & 131 & 0,845 & 0,041 \\
\hline ECE46Ea & Lençol de areia & \multirow{3}{*}{$\begin{array}{l}\text { NORTE/BITUPITÁ } \\
\text { (BARROQUINHA) }\end{array}$} & & & 3046 & 250 & 3,234 & 0,102 \\
\hline ECE46Eb & Lençol de areia & & $1857-1943$ & Algas & 1611 & 147 & 0,94 & 0,0571 \\
\hline ECE46Ebcim & Lençol de areia & & 1451 - 1522 & Cimento & & & & \\
\hline ECE49E & Lençol de areia & $\begin{array}{c}\text { NORTE/PRAIA NOVA } \\
\text { (CAMOCIM) }\end{array}$ & $4283-4422$ & Algas e moluscos & 2399 & 226 & 1,37 & 0,083 \\
\hline ECE51Ea & Lençol de areia & \multirow{2}{*}{$\begin{array}{l}\text { NORTE/MACEIÓ } \\
\text { (CAMOCIM) }\end{array}$} & & & 5727 & 503 & 4,034 & 0,215 \\
\hline ECE51Eb & Lençol de areia & & & & 5078 & 463 & 3.63 & 0,161 \\
\hline ECE52E & $\begin{array}{l}\text { Planície de } \\
\text { deflação }\end{array}$ & \multirow{2}{*}{$\begin{array}{l}\text { CENTRO/ITAREMA } \\
\text { (ITAREMA) }\end{array}$} & $1994-2152$ & Moluscos e algas & & & & \\
\hline ECE52Ecim & $\begin{array}{l}\text { Planície de } \\
\text { deflação }\end{array}$ & & $1517-1619$ & Cimento & & & & \\
\hline ECE53E & Lençol de areia & $\begin{array}{c}\text { CENTRO/ALMOFALA } \\
\text { (ITAREMA) }\end{array}$ & $2218-2309$ & Algas & 2602 & 259 & 2,74 & 0,16 \\
\hline ECE58E & Lençol de areia & $\begin{array}{c}\text { SUL/IMBOACA } \\
\text { (TRAIRI) }\end{array}$ & $2113-2309$ & Algas e moluscos & & & & \\
\hline ECE55E & $\begin{array}{c}\text { Planície de } \\
\text { deflação }\end{array}$ & $\begin{array}{l}\text { SUL/GUAJIRU } \\
\text { (TRAIRI) }\end{array}$ & $1240-1304$ & Algas & & & & \\
\hline ECE62cim & $\begin{array}{l}\text { Planície de } \\
\text { deflação }\end{array}$ & \multirow{3}{*}{$\begin{array}{l}\text { SUL/PIRIQUARA } \\
\text { (PARACURU) }\end{array}$} & $1049-1178$ & Cimento & & & & \\
\hline ECE62E & $\begin{array}{l}\text { Planície de } \\
\text { deflação }\end{array}$ & & $1687-1812$ & Algas e moluscos & & & & \\
\hline ECE63E & $\begin{array}{c}\text { Planície de } \\
\text { deflação }\end{array}$ & & $1204-1256$ & Algas & & & & \\
\hline
\end{tabular}


Os três tipos de datações realizados nos eolianitos permitiram obter tanto idades mínimas (AMS dos cimentos e LOE) quanto máximas (AMS dos bioclastos) de deposição, por amostra. As idades mínimas correspondentes a datações AMS do cimento variam de aproximadamente 1600 a 1000 anos A.P, o que aponta para um evento de cimentação bem definido no tempo. Já as idades LOE variam num espectro muito mais amplo, de 5700 a 650 anos, o que, em parte, está ligado ao maior número de amostras (21) datadas por esse método. Um fato que reforça esta observação é que a datação de bioclastos por AMS, feita em número de amostras pouco menor (17), resultou em um intervalo de tempo parecido com o das idades LOE: 4400 até 1000anos A.P. Em duas amostras (EPI40 e ECE53E), a idade LOE foi mais antiga que a AMS de bioclasto, além da margem de erro, o que é sugestivo de problema analítico.

A distribuição geográfica de idades, por setor, está representada nas figuras 6.6 a 6.9. A idade obtida por datação de cimento no setor sul (Figura 6.9) é pouco séculos mais nova do que as dos setores norte e centro (Figuras 6.6 a 6.8), e as idades de bioclastos, acompanhando esta tendência, apresentam decréscimo gradual no setor norte para o setor sul. Já as datações LOE concentram-se no setor norte (16 amostras no norte versus apenas uma no centro), o que impossibilita comparar os setores. 


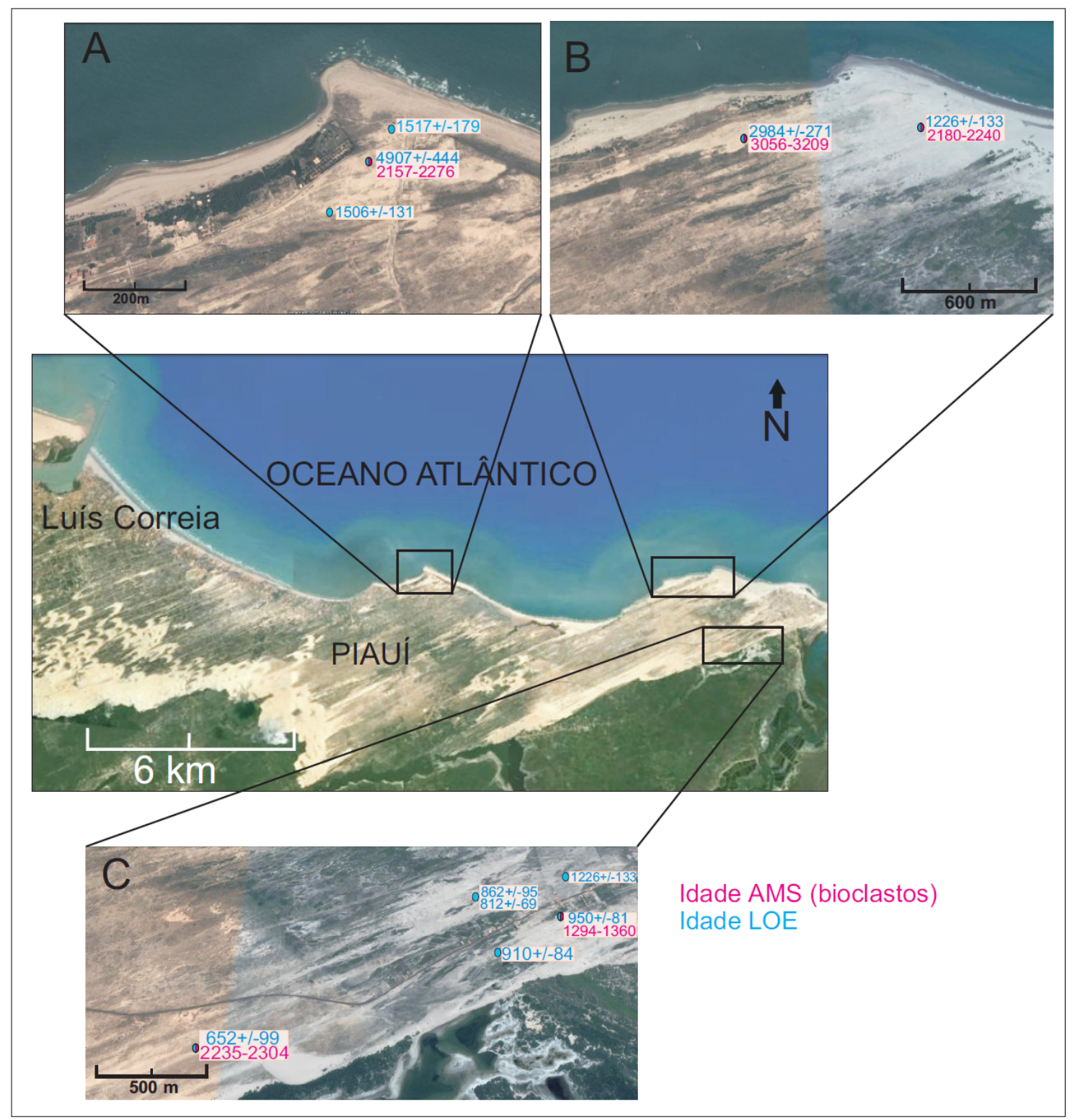

Figura 6.6. Idades máximas e mínimas obtidas nos eolianitos do setor norte, município de Luís Correia, Piauí: A. Itaqui; B. Carnaubinha-Maramar; e C. Macapá. 


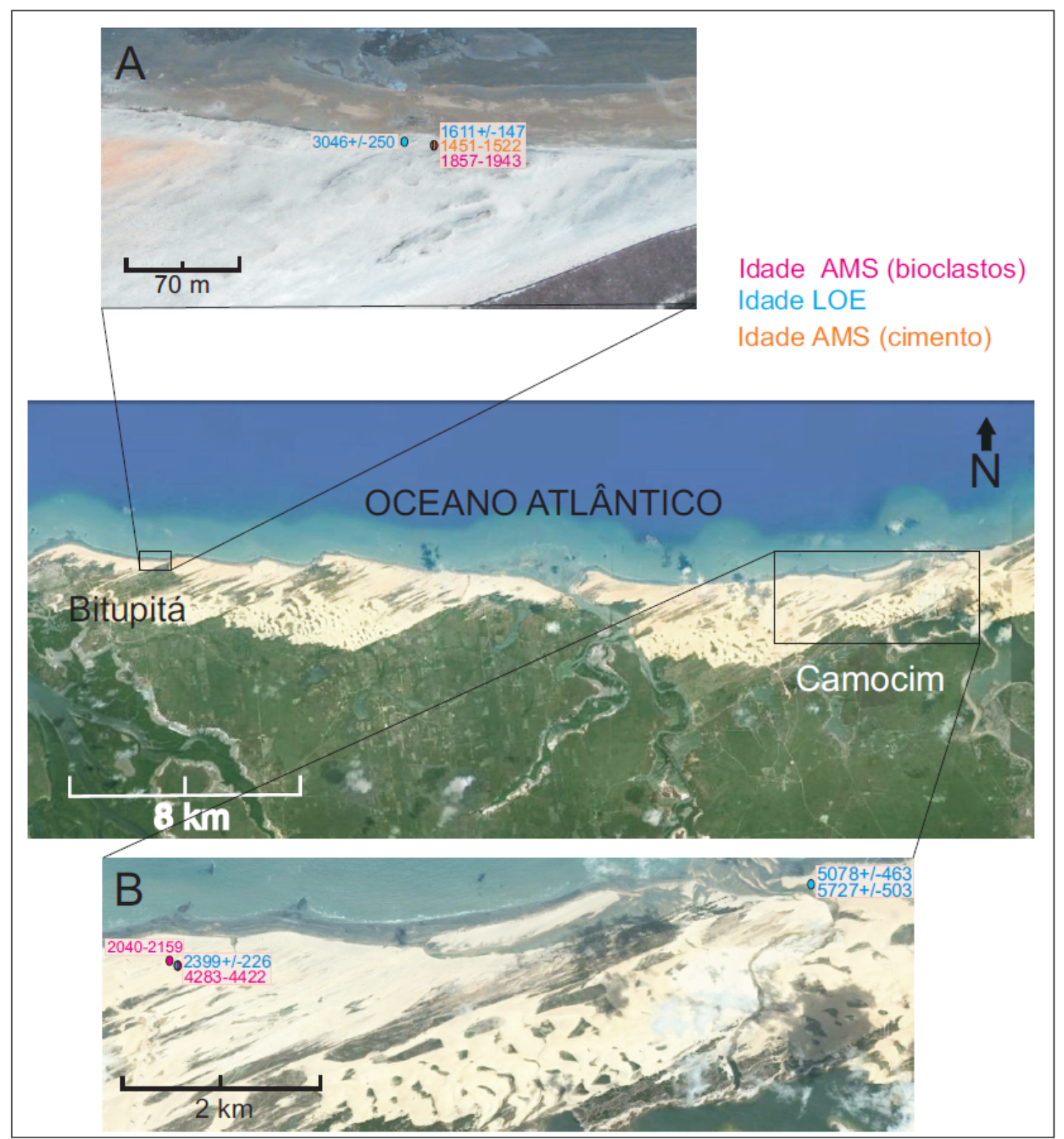

Figura 6.7. Idades máximas (AMS de bioclasto) e mínimas (AMS de cimento e LOE) obtidas nos eolianitos do setor norte, no Ceará: A. Bitupitá (município de Barroquinha); e B. Praia Nova e Maceió (município de Camocim). 


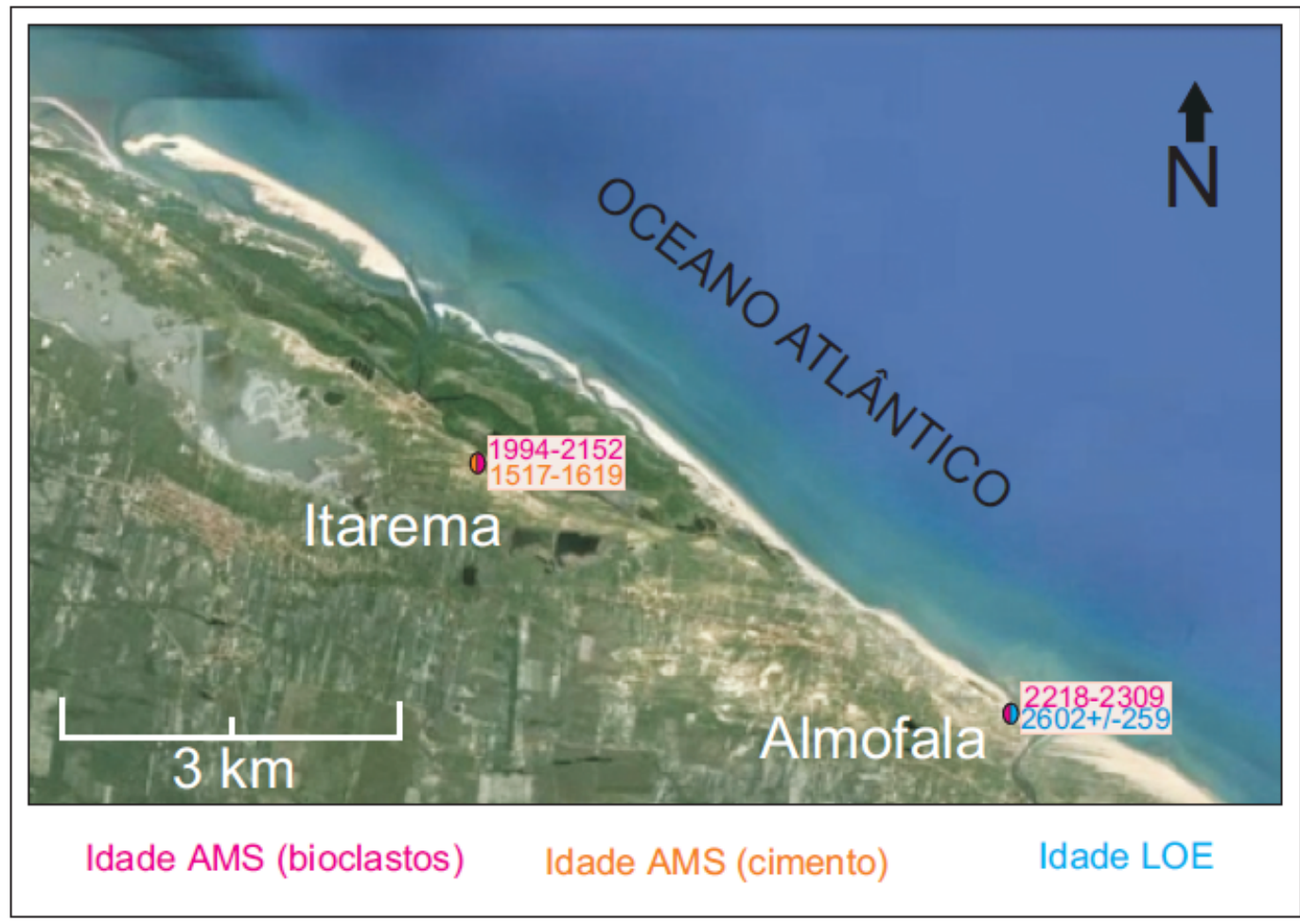

Figura 6.8. Idades máximas (AMS de bioclasto) e mínimas (AMS de cimento e LOE) obtidas nos eolianitos do setor centro. 


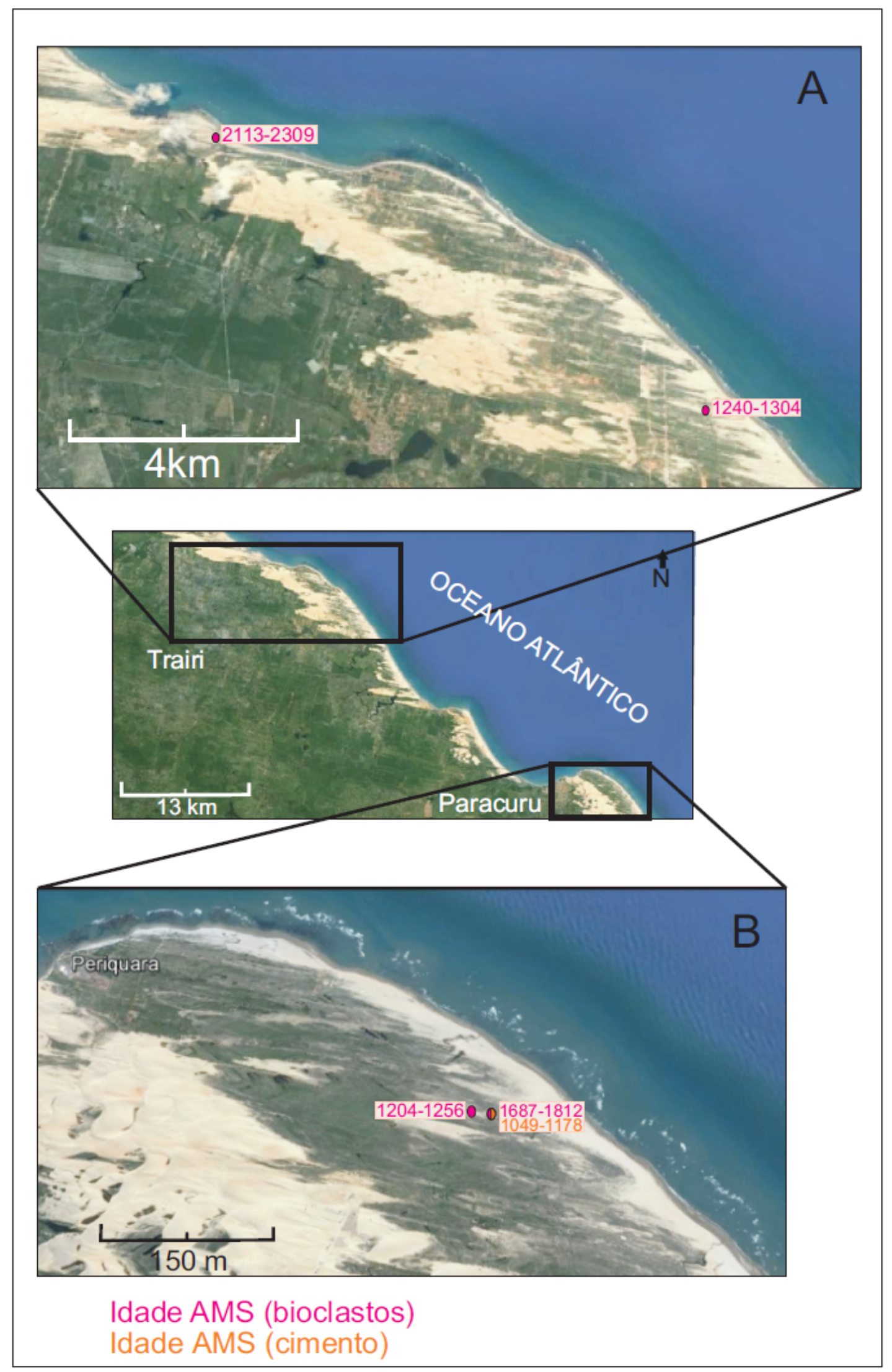

Figura 6.9. Idades máximas (AMS de bioclasto) e mínima (AMS de cimento) obtidas nos eolianitos do setor sul: A. Trairi; e B. Paracuru. 
Para avaliar com maior precisão e detalhe a variação geográfica das idades sugerida nas figuras 6.6 a 6.9, os resultados de datação das amostras de eolianito foram lançadas em função da distância à costa (Figura 6.10), inclusive por setor geográfico (Figuras $6.11 \mathrm{a}$ 6.12), e da distância de W para E (Figura 6.13).

O padrão de variação das idades com a distância à costa indica que os eolianitos mais próximos da fonte praial são mais antigos que os mais distantes (Figura 6.10); amostras que não estão dentro deste padrão, como, por exemplo, EPI24E e EPI40, as quais estão longe da costa ( $1100 \mathrm{~m}$ e $360 \mathrm{~m}$, respectivamente), mas possuem idades relativamente velhas (3000 e 2200-4900anos), são aquelas tomadas na parte inferior de afloramentos mais espessos, onde é possível, portanto, terem sido amostradas gerações mais antigas.

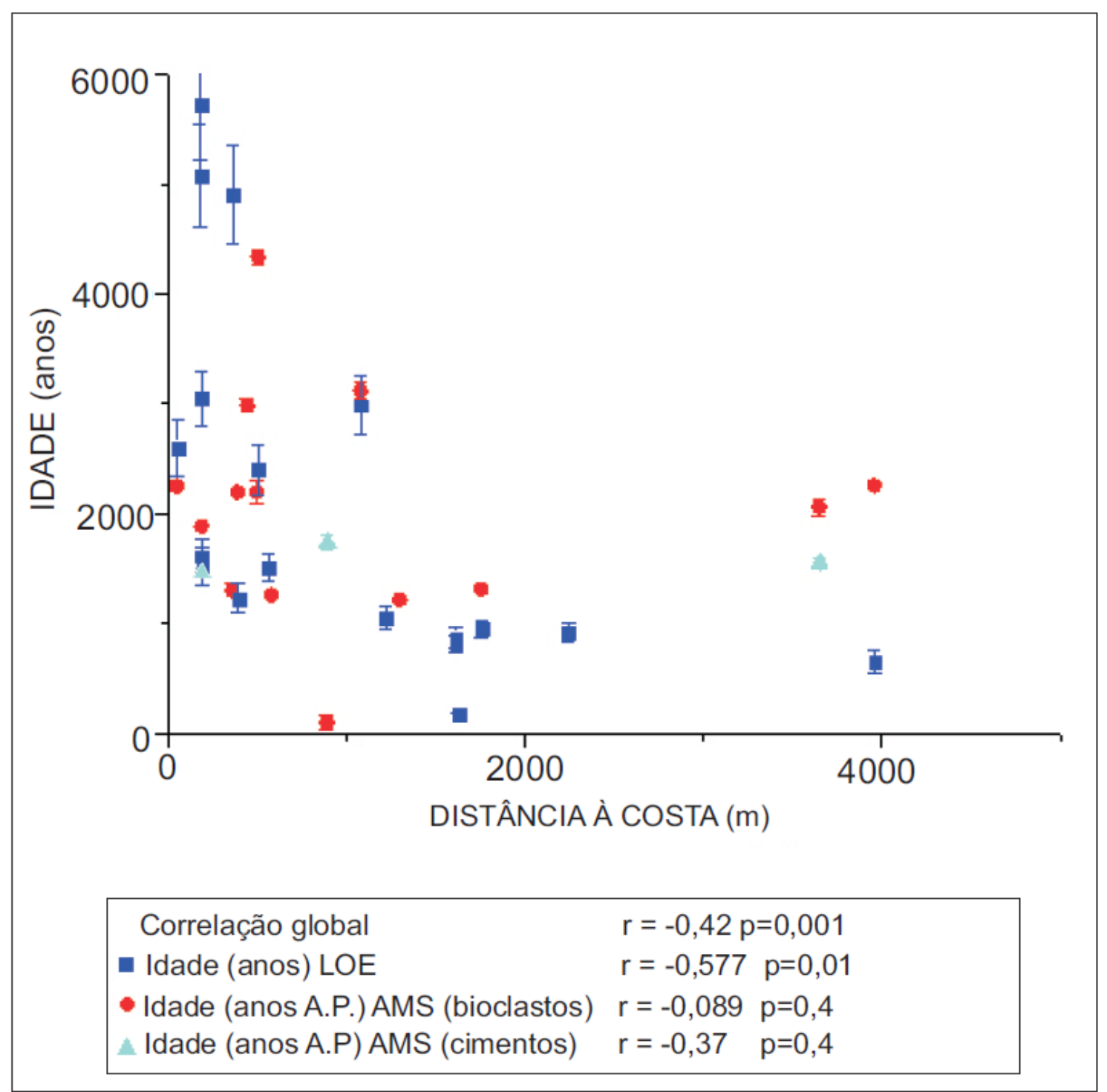

Figura 6.10. Gráfico de dispersão das idades de eolianitos em função da distância à costa, com seus respectivos erros. Datações LOE e AMS de cimento podem ser consideradas idades mínimas do depósito, enquanto as AMS de bioclastos representam idades máximas.

Mesma tendência de aumento de idade com a redução da distância à costa pode-se observar tanto no setor norte (Figura 6.11), quanto nas amostras agrupadas dos setores 
centro e sul (Figura 6.12). Os resultados são estatisticamente mais consistentes no setor norte, já que houve aí maior número de amostras coletadas.

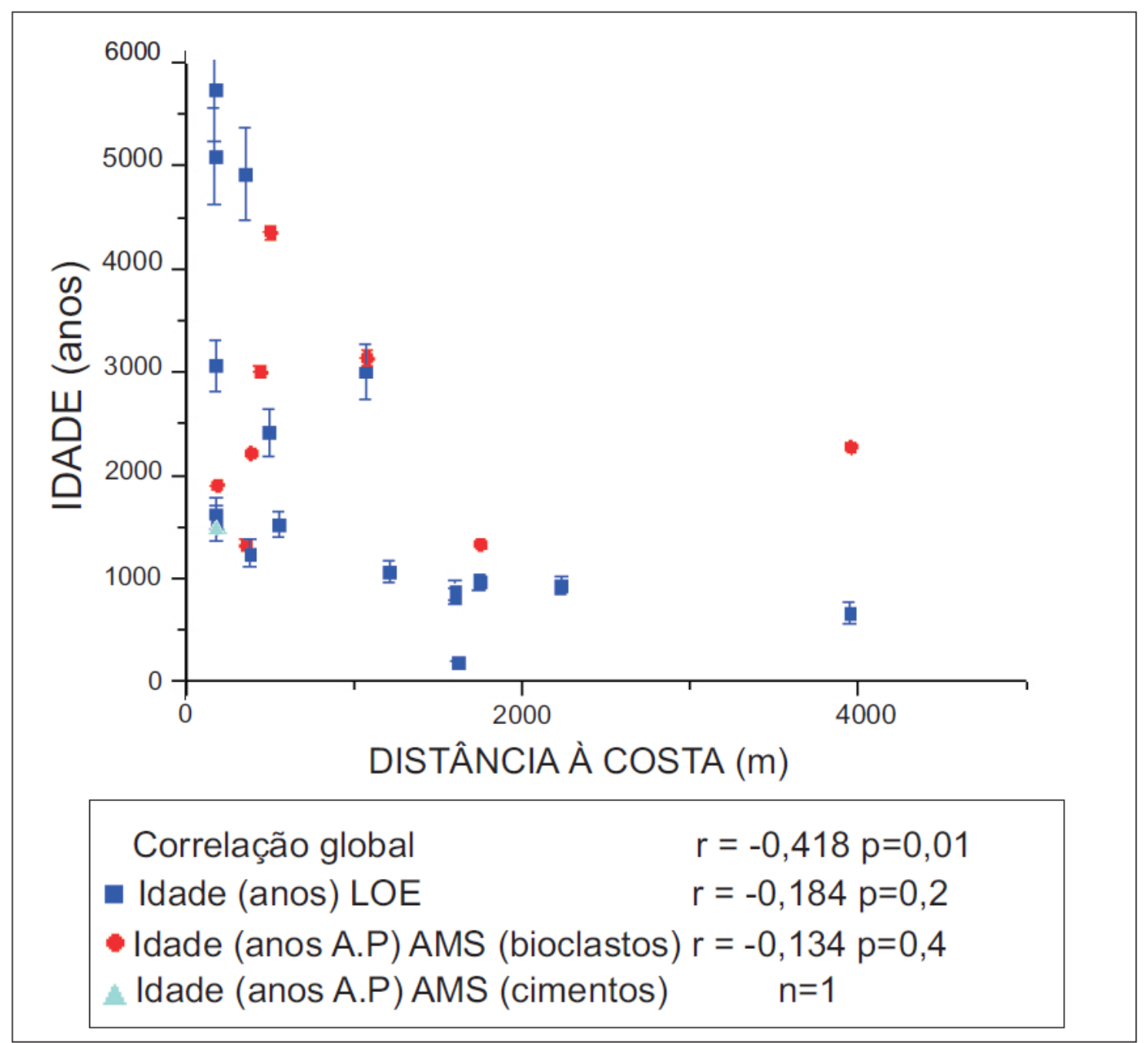

Figura 6.11. Gráfico de dispersão das idades de eolianitos em função da distância à costa, com seus respectivos erros, no setor norte. Datações LOE e AMS de cimento podem ser consideradas idades mínimas do depósito, enquanto as AMS de bioclastos representam idades máximas. 


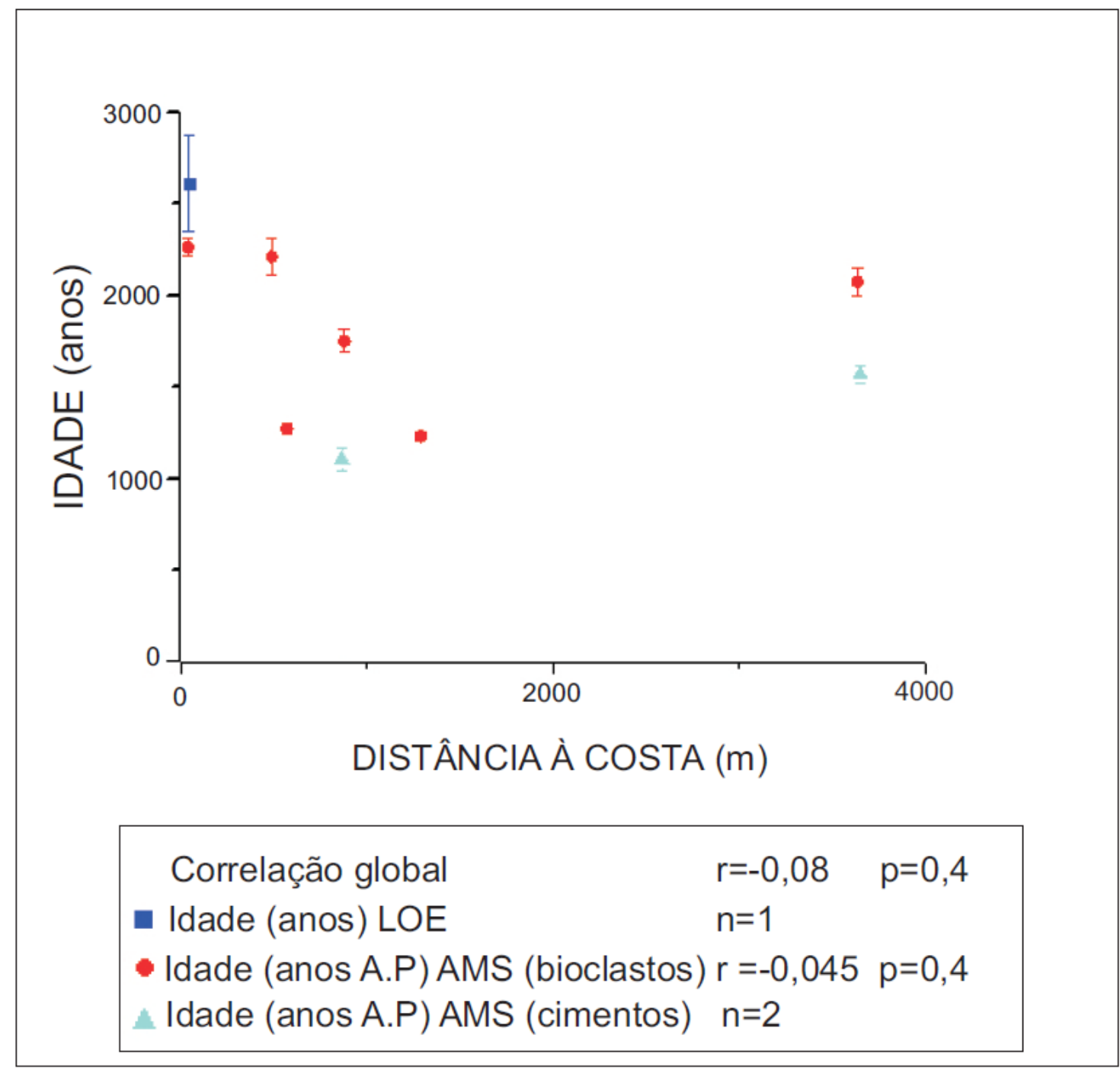

Figura 6.12. Gráfico de dispersão das idades de eolianitos em função da distância à costa, com seus respectivos erros, nos setores centro e sul agrupados. Datações LOE e AMS de cimento podem ser consideradas idades mínimas do depósito, enquanto as AMS de bioclastos representam idades máximas.

$\mathrm{Na}$ análise das idades segundo a distância W-E (Figura 6.13), as idades caem do setor norte para o sul, porém com baixa consistência estatística, já que não se trata de tendência contínua. Assim, o que se pode afirmar apenas é que as maiores idades são encontradas no setor norte, seguido do centro e do sul. $\mathrm{O}$ setor norte apresenta tendência linear para idades cada vez mais antigas rumo E, de tal modo que as maiores idades encontradas neste setor, em toda a área de estudo, concentram-se entre os quilômetros $35 \mathrm{e}$ 65 (região de Barroquinha e Camocim); mesma tendência para idades mais velhas rumo $\mathrm{E}$ se observa no setor centro, porém aí com baixo número de amostras e, portanto menor significado estatístico. 


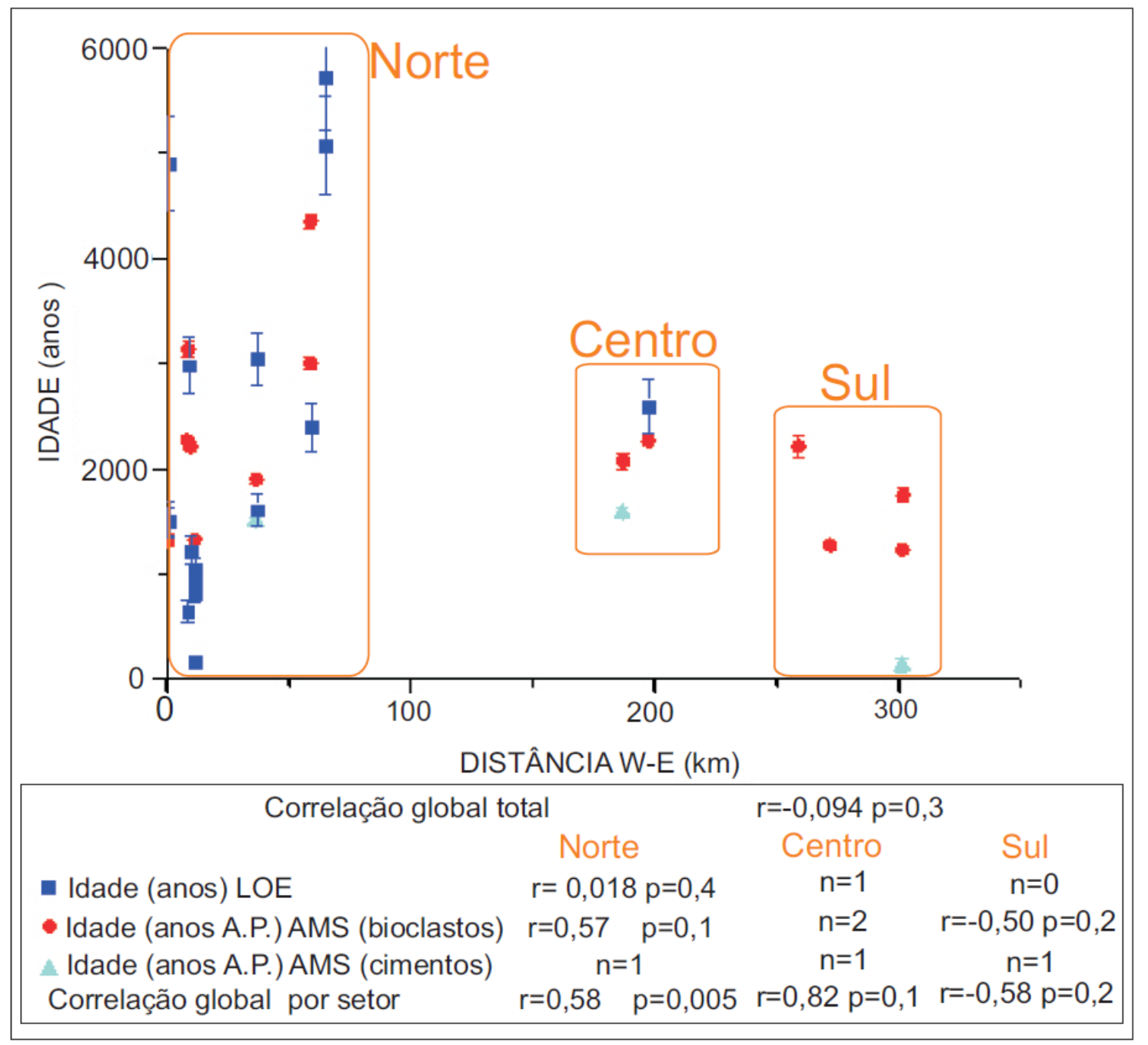

Figura 6.13. Gráfico de dispersão das idades de eolianitos em função da distância de $\mathrm{W}$ para $\mathrm{E}$, com seus respectivos erros. Datações LOE e AMS de cimento podem ser consideradas idades mínimas do depósito, enquanto AMS de bioclastos representam idades máximas. Notar tendências de variação opostas entre os setores norte e centro-sul.

\subsubsection{Depósitos associados aos eolianitos}

Os resultados das datações nos depósitos associados lateralmente ou como substrato dos eolianitos encontram-se na Tabela 2. Dentre elas, a única datação AMS em cimento foi feita na amostra EPI45Xc de Luís Correia, no setor norte, um arenito calcífero com gastrópodes continentais inteiros (Pomacea sp.) in situ, soterrado por camada de areia eólica da planície deflacionária. A idade obtida, cerca de 1500 a 1400 anos A.P., é coincidente com a encontrada no cimento do próprio eolianito nos setores norte e cerca de 200 anos mais nova que a dos gastrópodes encontrados em meio a mesma camada (amostra EPI45Xg). Por outro lado, a idade LOE da amostra EPI45Xa, coletada na mesma sucessão, porém em camada arenosa subjacente, não cimentada por carbonato, é de cerca de $13 \mathrm{ka}$, indicando assim uma discordância entre as duas camadas.

A amostra EPI04 apresenta situação estratigráfica análoga a de EPI45, isto é, arenito calcífero com gastrópodes in situ, soterrado por rastro linear residual terrígeno da 
planície deflacionária recente. A idade ${ }^{14} \mathrm{C}$ obtida no gastrópode foi cerca de 1000 anos mais antiga.

Tabela 2. Relação das idades das amostras de depósitos associados aos eolianitos. A datação ${ }^{14} \mathrm{C}$ destacada com cor (código "cim") refere-se a cimento carbonático.

\begin{tabular}{|c|c|c|c|c|c|c|c|c|}
\hline AMOSTRA & $\begin{array}{c}\text { FÁCIES } \\
\text { MORFOLÓGICA DE } \\
\text { OCORRÊNCIA } \\
\text { (TIPO DE DEPÓSITO) } \\
\end{array}$ & $\begin{array}{l}\text { SETOR/ÁREA } \\
\text { E/OU } \\
\text { MUNICÍPIO }\end{array}$ & $\begin{array}{l}\text { IDADE }{ }^{14} \mathrm{C} \\
(\operatorname{anos} \mathrm{AP})\end{array}$ & $\begin{array}{l}\text { TIPO DE MATERIAL } \\
\text { DATADO POR AMS }\end{array}$ & $\begin{array}{l}\text { IDADE LOE } \\
\text { (anos) }\end{array}$ & $\begin{array}{l}\text { ERRO } \\
\text { LOE } \\
\text { (anos) }\end{array}$ & $\begin{array}{l}\text { TAXA } \\
\text { DE } \\
\text { DOSE } \\
\text { (Gy) }\end{array}$ & $\begin{array}{l}\text { ERRO } \\
\text { TAXA DE } \\
\text { DOSE }\end{array}$ \\
\hline EPIO2 & $\begin{array}{l}\text { Planície de deflação } \\
\text { (rastro linear residual } \\
\text { terrígeno) }\end{array}$ & \multirow[b]{2}{*}{$\begin{array}{l}\text { NORTE / LUÍS } \\
\text { CORREIA }\end{array}$} & & & 365 & 31 & 0,277 & 0,01 \\
\hline EPIO4 & $\begin{array}{l}\text { Planície de deflação } \\
\text { (arenito calcífero } \\
\text { com gastrópodes in } \\
\text { situ sob rastro linear } \\
\text { residual terrígeno) }\end{array}$ & & $2354-2502$ & $\begin{array}{l}\text { Molusco (gastrópode } \\
\text { Pomacea sp.) }\end{array}$ & & & & \\
\hline EPI13R & $\begin{array}{l}\text { Planície de deflação } \\
\text { (rastro linear residual } \\
\text { com cimentação } \\
\text { carbonática } \\
\text { incipiente) }\end{array}$ & $\begin{array}{c}\text { NORTE / } \\
\text { MACAPÁ, } \\
\text { LUÍS CORREIA }\end{array}$ & & & 170 & 17 & 0,1512 & 0,010 \\
\hline Epi45Xa & $\begin{array}{c}\text { Planície de deflação } \\
\text { (areia sob arenito } \\
\text { calcífero) }\end{array}$ & \multirow{3}{*}{$\begin{array}{c}\text { NORTE / LUÍS } \\
\text { CORREIA }\end{array}$} & & & 13306 & 1001 & 4,23 & 0,15 \\
\hline EPI45Xcim & $\begin{array}{l}\text { Planície de deflação } \\
\text { (arenito calcífero } \\
\text { com gastrópodesin } \\
\text { situ, soterrado) }\end{array}$ & & $1398-1525$ & Cimento & & & & \\
\hline EPI45Xg & $\begin{array}{l}\text { Planície de deflação } \\
\text { (arenito calcífero } \\
\text { com gastrópodes in } \\
\text { situ, soterrado) }\end{array}$ & & $1602-1724$ & $\begin{array}{l}\text { Molusco (gastrópode } \\
\quad \text { Pomacea sp.) }\end{array}$ & & & & \\
\hline ECE49Econ & $\begin{array}{c}\text { Lençol de areia } \\
\text { (calcirrudito } \\
\text { bioclástico de } \\
\text { carapaças inteiras) }\end{array}$ & $\begin{array}{l}\text { NORTE / } \\
\text { PRAIA NOVA, } \\
\text { CAMOCIM }\end{array}$ & $2040-2159$ & $\begin{array}{c}\text { Molusco } \\
\text { (gastrópodeGastrocopta } \\
s p .)\end{array}$ & & & & \\
\hline ECE51PB & $\begin{array}{l}\text { Falésia costeira } \\
\text { (“Pós-Barreiras") }\end{array}$ & \multirow{2}{*}{$\begin{array}{l}\text { NORTE / } \\
\text { MACEIÓ, } \\
\text { CAMOCIM }\end{array}$} & & & 70839 & 4850 & 0,644 & 0,044 \\
\hline ECE51Y & $\begin{array}{l}\text { Falésia costeira } \\
\text { (beach-rock) }\end{array}$ & & $5417-5442$ & $\begin{array}{l}\text { Fragmentos de } \\
\text { moluscos }\end{array}$ & & & & \\
\hline
\end{tabular}

A idade LOE mais nova obtida, de 170 anos, é a da amostra EPI13R, coletada em meio à planície deflacionária da área de Macapá, e que corresponde a um rastro linear residual apenas moderadamente coeso, com alternância entre lâminas cimentadas e não cimentadas, portanto em estágio muito incipiente de litificação.

A idade LOE mais antiga, $71 \mathrm{ka}$ aproximadamente, obteve-se no "Pós-Barreiras" (ECE51PB) e é mais nova que os resultados de datação LOE (240ka) encontrados por Guedes (2012) nesta unidade estratigráfica, no Maranhão. No depósito de beach-rock aflorante no mesmo ponto (ECE51Y), a idade obtida em bioclastos de moluscos (bivalve articulado) sem sinal de abrasão foi de cerca de 5400 anos cal A.P. O nível de ocorrência do beach-rock foi estimado em 2 a $4 \mathrm{~m}$ acima da zona média de espraiamento. 


\subsubsection{Fácies deposicionais}

$\mathrm{Na}$ classificação de fácies, agruparam-se em separado as de eolianito e as de depósitos não eólicos e/ou não carbonáticos a eles associados.

Além da litificação por cimento carbonático, os eolianitos distinguem-se no campo pela presença conspícua e pervasiva de laminação de espessura milimétrica a submilimétrica, com segregação de grãos quanto a tamanho e com boa seleção granulométrica por lâmina, ressaltada por cimentação e por erosão diferenciais. Esta estrutura sedimentar corresponde à pin-stripe lamination (laminação risca de agulha), definida por Friberger \& Shenk (1988), e considerada por esses autores como a mais diagnóstica das feições de deposição eólica. Em parte dos casos, ela foi confirmada na análise petrográfica (Artigo 2).

Cinco fácies deposicionais foram reconhecidas nos eolianitos (Quadro 5 e Figura 6.14), todas de arenito com estratificações cruzadas (Ac), distinguindo-se entre si quanto ao ângulo de mergulho dominante destas estratificações, se alto, acima de $10^{\circ}\left(\mathbf{A c}_{\mathbf{a}}, \mathbf{A c}_{\mathbf{a}} \mathbf{r}_{\mathbf{e}}\right.$ e $\mathbf{A} \mathbf{c}_{\mathbf{f}} \mathbf{r}_{\mathbf{a}}$ ) ou baixo ( $\mathbf{A} \mathbf{c}_{\mathbf{b}}$ e $\left.\mathbf{A} \mathbf{c}_{\mathbf{b}} \mathbf{r}_{\mathbf{a}}\right)$, quanto à geometria acanalada/festonada $\left(\mathbf{A c}_{\mathbf{f}} \mathbf{r}_{\mathbf{a}}\right)$ ou plana (demais fácies) das estratificações e quanto à presença, escassa $\left(\mathbf{A c}_{\mathbf{a}} \mathbf{r}_{\mathbf{e}}\right)$ ou abundante $\left(A \mathbf{c}_{\mathbf{f}} \mathbf{r}_{\mathbf{a}}, \mathbf{A c}_{\mathbf{b}} \mathbf{r}_{\mathbf{a}}\right)$, de rizoconcreções.

Quadro 5. Sumário de descrição de fácies deposicionais em eolianitos

\begin{tabular}{|c|l|c|c|}
\hline \multirow{2}{*}{$\begin{array}{c}\text { Código de } \\
\text { fácies }\end{array}$} & \multicolumn{1}{|c|}{ Descrição } & \multicolumn{1}{|c|}{$\begin{array}{c}\text { Espessura visível } \\
(\mathbf{m})\end{array}$} \\
\cline { 3 - 4 } & \multicolumn{1}{|c|}{ Séries } & Fácies \\
\hline $\mathbf{A} \mathbf{c}_{\mathbf{a}}$ & $\begin{array}{l}\text { Quartzo arenito fino a médio com estratificação cruzada plana de } \\
\text { ângulo alto }\left(>10^{\circ}\right)\end{array}$ & $0,4-0,8$ & $0,4-2,5$ \\
\hline $\mathbf{A} \mathbf{c}_{\mathbf{b}}$ & $\begin{array}{l}\text { Quartzo arenito fino a grosso com estratificação cruzada plana de } \\
\text { ângulo baixo }\left(\leq 10^{\circ}\right)\end{array}$ & $0,4-1,2$ & $0,4-6$ \\
\hline $\mathbf{A c}_{\mathbf{a}} \mathbf{r}_{\mathbf{e}}$ & $\begin{array}{l}\text { Quartzo arenito fino a médio com estratificação cruzada plana de } \\
\text { ângulo alto }\left(>10^{\circ}\right) \text { e rizoconcreções escassas }(<10 \% \text { em volume })\end{array}$ & $0,6-2$ & $0,6-3,5$ \\
\hline $\mathbf{A c}_{\mathbf{b}} \mathbf{r}_{\mathbf{a}}$ & $\begin{array}{l}\text { Quartzo arenito fino a grosso com estratificação plano-paralela } \\
\text { ou cruzada de ângulo baixo }\left(\leq 10^{\circ}\right) \text { e rizoconcreções abundantes } \\
(>10 \% \text { em volume })\end{array}$ & $0.5-1$ & $1-10$ \\
\hline $\mathbf{A c}_{\mathbf{f}} \mathbf{r}_{\mathbf{a}}$ & $\begin{array}{l}\text { Quartzo arenito médio a fino com estratificaçãocruzada } \\
\text { acanalada/festonada e rizoconcreções abundantes (>10\% em } \\
\text { volume })\end{array}$ & $1-3$ & $3-10$ \\
\hline
\end{tabular}




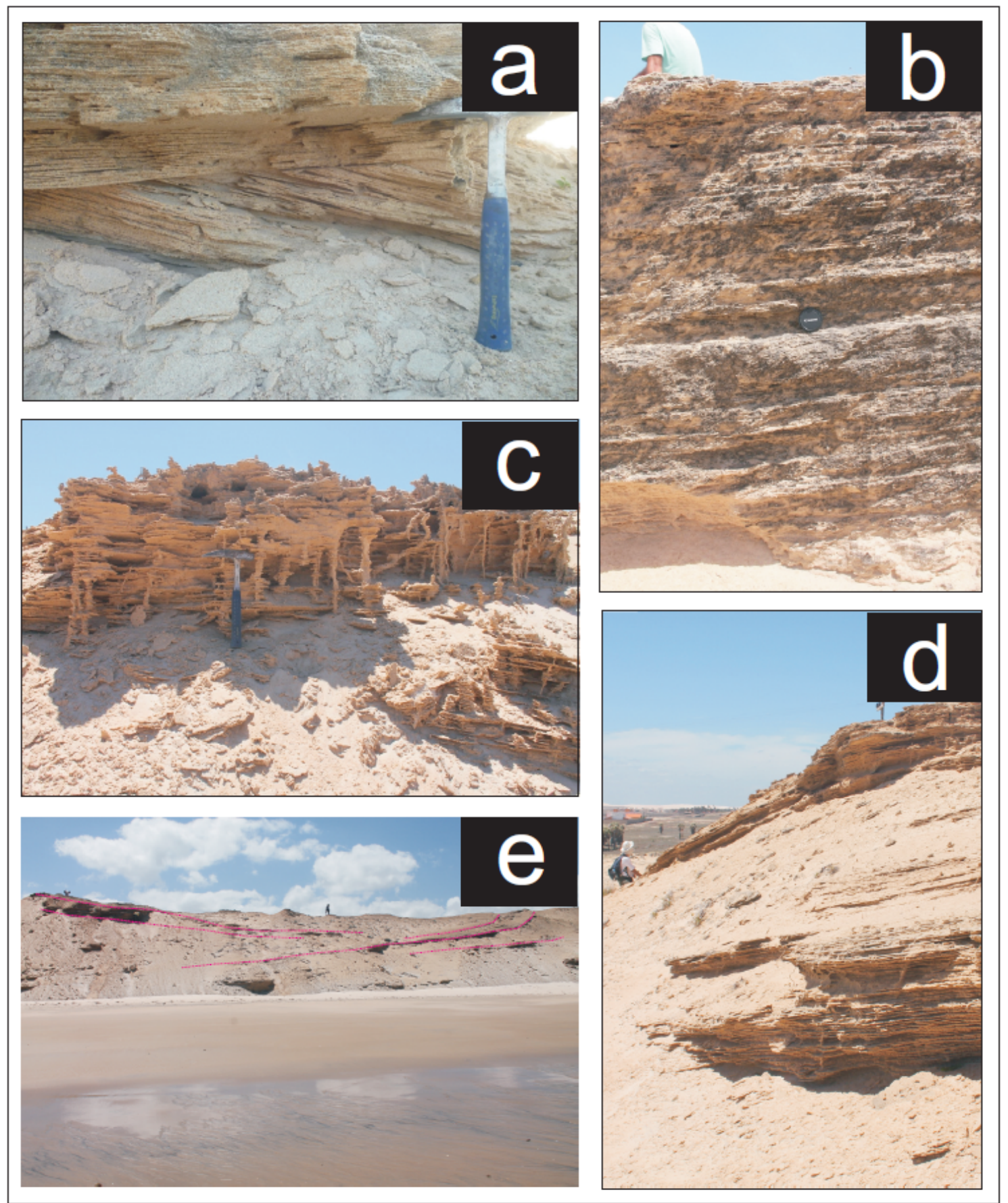

Figura 6.14. Fácies deposicionais mais comuns presentes nos eolianitos da área de estudo: a. arenito com estratificação cruzada de ângulo alto $\left(A c_{a}\right)$; $\mathbf{b}$. arenito com estratificação cruzada de ângulo baixo $\left(\mathrm{Ac}_{\mathrm{b}}\right)$; c. arenito com estratificação cruzada de ângulo baixo e rizoconcreções abundantes $\left(\mathrm{Ac}_{\mathrm{b}} \mathrm{r}_{\mathrm{a}}\right)$; d. arenito com estratificação cruzada de ângulo alto e rizoconcreções escassas $\left(\mathrm{Ac}_{\mathrm{a}} \mathrm{r}_{\mathrm{e}}\right)$; e e. arenito com estratificação cruzada acanalada-festonada e rizoconcreções abundantes $\left(\mathrm{Ac}_{\mathrm{f}} \mathrm{r}_{\mathrm{a}}\right)$. Foto a feita na área de Macapá, b em Imboaca, c e d em Itaqui, e e em Bitupitá. 
Sete fácies foram identificadas nos depósitos não eólicos e/ou não carbonáticos associados aos eolianitos (Quadro 5 e Figura 6.15). O aspecto maciço (ausência de estruturas sindeposicionais aparentes) é a característica mais distintiva, aparecendo em quatro delas (Rm, Rg, Am, Amg). Destaca-se também, em quatro das fácies associadas (Rg, Amg, Apb e Apr $\mathbf{e}$ ), a presença de bioclastos rudáceos ou de conchas em suposta posição de vida. A fácies Amg contém gastrópodes do gênero Pomacea subdecimétricos inteiros, em meio ao sedimento arenoso, aparentemente vestígios de vida in situ. Carapaças centimétricas inteiras de gastrópodes (gênero Gastrocopta) ocorrem também na fácies Rg, mas aqui o fato de o depósito ser suportado por estas carapaças sugere que os vestígios de vida foram ligeiramente retrabalhados, tendo a matriz arenosa em parte retirada.

Nos depósitos associados aos eolianitos (Quadro 6), a possível presença da laminação risca de agulha foi suspeita apenas na $\mathbf{A p r}_{\mathbf{e}}$, dentre as fácies bioclásticas com cimento carbonático, e na $\mathbf{R A r}$ ( ("pós-Barreiras"), dentre as terrígenas, em ambos os casos com ocorrência subordinada a camadas arenáceas decimétricas a subdecimétricas intercaladas com horizontes rudáceos.

Quadro 6. Sumário de descrição de fácies deposicionais nos depósitos sedimentares associados aos eolianitos.

\begin{tabular}{|c|c|c|c|}
\hline \multirow{2}{*}{$\begin{array}{l}\text { Código de } \\
\text { fácies }\end{array}$} & \multirow{2}{*}{ Descrição } & \multicolumn{2}{|c|}{ Espessura visível (m) } \\
\hline & & Séries & Fácies \\
\hline $\mathbf{R m}$ & $\begin{array}{l}\text { Rudito polimítico maciço pardo avermelhado, com ou sem } \\
\text { ferricretes (Formação Barreiras) }\end{array}$ & $0,3-0,7$ & $0,3-1,5$ \\
\hline $\mathbf{R A r}_{\mathbf{a}}$ & $\begin{array}{l}\text { Rudito e quartzo arenito médio a grosso, interestratificados } \\
\text { em lentes decimétricas, com padrão geral granodecrescente } \\
\text { ascendente erizoconcreções abundantes no topo, cor } \\
\text { amarelada a avermelhada ("pós-Barreiras") }\end{array}$ & $0,4-1,0$ & $0,8-2,0$ \\
\hline Am & Areia quartzosa média a fina, maciça & $0,1-0,7$ & $0,1-0,7$ \\
\hline Amg & $\begin{array}{l}\text { Quartzo arenito médio a fino, maciço, com gastrópodes } \\
\text { aquáticos dominantemente inteiros (Pomacea sp.), de } \\
\text { diferentes tamanhos, e escurecimento ascendente gradual, } \\
\text { culminando no topo por um horizonte preto de cerca de } 10 \\
\text { cm de espessura }\end{array}$ & 0,5 & 0,5 \\
\hline Apb & $\begin{array}{l}\text { Arenito muito grosso a médio com séries cuneiformes } \\
\text { decimétricasde laminação plano-paralela e tendência } \\
\text { granodecrescente ascendente, contendobioclastose terrígenos } \\
\text { rudáceos (beach-rock) }\end{array}$ & $0,1-0,4$ & $0,1-0,6$ \\
\hline Ap & $\begin{array}{l}\text { Areia quartzosa fina a média, com estratificação plano- } \\
\text { paralela localmente evidente }\end{array}$ & $0,7-1,2$ & $0,7-1,2$ \\
\hline Rg & $\begin{array}{l}\text { Calcirrudito conchífero, maciço a incipientemente } \\
\text { estratificado, de gastrópodes terrestres (Gastrocopta sp.) }\end{array}$ & $0,2-0,3$ & $0,2-0,3$ \\
\hline Apr $_{e}$ & $\begin{array}{l}\text { Arenito médio a grosso, com estratificação decimétrica sub- } \\
\text { horizontal marcada por concentrações de bioclastos } \\
\text { rudáceos, com laminação plano-paralela e rizoconcreções } \\
\text { escassas }\end{array}$ & $0,1-0,3$ & $0,3-0,8$ \\
\hline
\end{tabular}



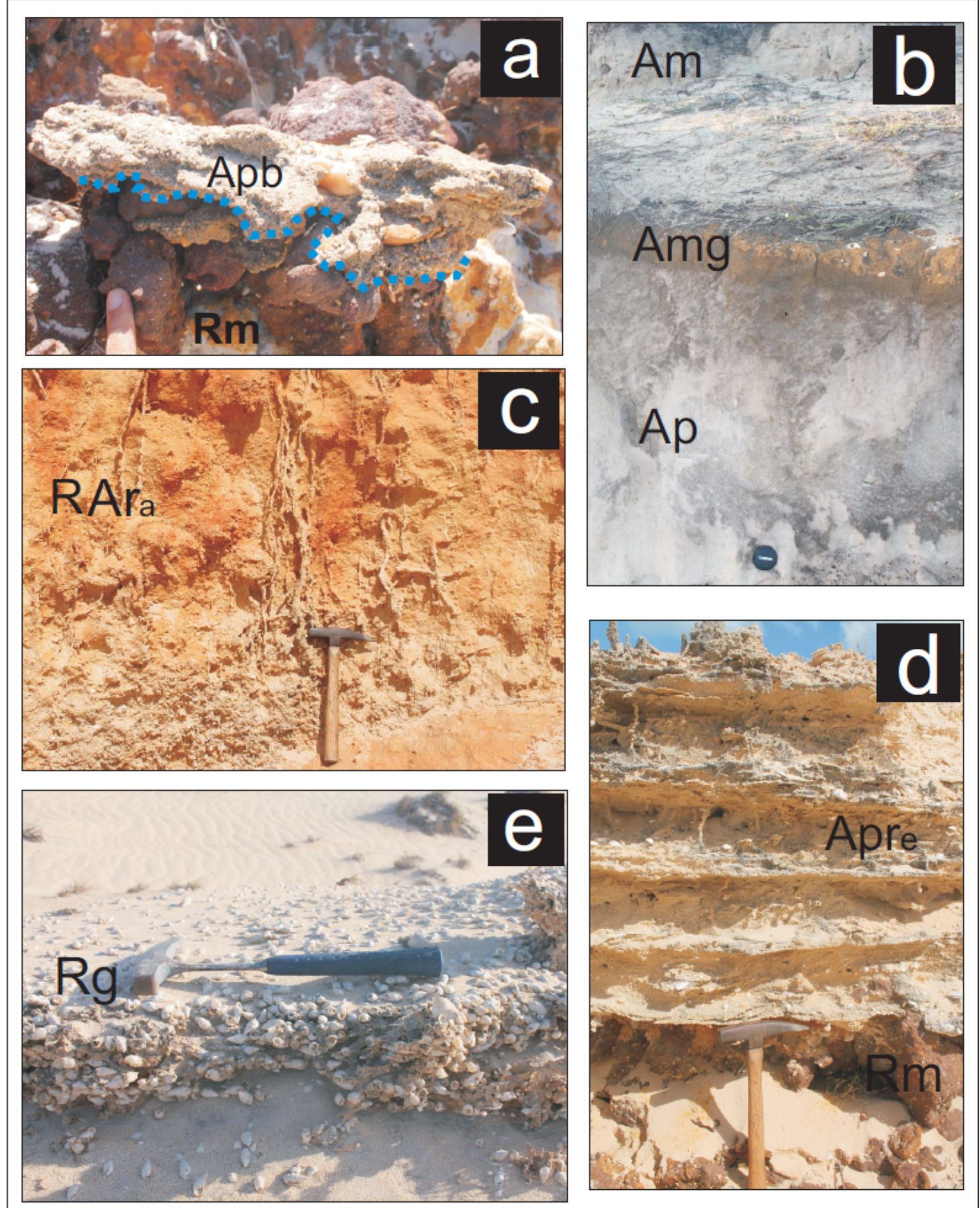

Figura 6.15. Fácies dos depósitos sedimentares associados aos eolianitos: a. rudito maciço com ferricretes correspondente à Formação Barreiras $(\mathrm{Rm})$, sobreposto, em contato discordante, por arenito de laminação plano-paralela com bioclastos correspondente a beach-rock (Apb) (Bitupitá, $\mathrm{CE})$; b. arenito médio com laminação plano-paralela (Ap), em contacto transicional para arenito maciço com gastrópodes e horizonte preto superior (Amg), este sobreposto por areia média a fina maciça (Am) (Luís Correia, PI); c. rudito, na base, passando acima,em contato transicional, a quartzo arenito médio a grosso com rizoconcreções abundantes $\left(\mathrm{RAr}_{\mathrm{a}}\right)$ (Maceió, $\mathrm{CE}$ ); d. rudito maciço com ferricretes $(\mathrm{Rm})$, coberto, em disconformidade erosiva, por arenito médio a grosso com laminação plano-paralela, bioclastos e rizoconcreções escassas $\left(\mathrm{Apr}_{\mathrm{e}}\right)$ (Maceió, CE); e e. rudito maciço com carapaças de gastrópodes dominantemente inteiras (Rg) (Praia Nova, $\mathrm{CE}$ ). 


\subsubsection{Distribuição espacial de fácies deposicionais e associações de fácies}

\subsubsection{Setor norte}

O setor norte apresenta-se, nas figuras 6.16 a 6.20 subdividido em cinco subáreas de $\mathrm{W}$ para $\mathrm{E}$, adjacentes, no rumo do vento efetivo, às praias de Carnaubinha, Maramar, Macapá, Bitupitá, Nova e Maceió. Os eolianitos deste setor apresentam principalmente as fácies $\mathbf{A c}_{\mathbf{a}}$ e $\mathbf{A} \mathbf{c}_{\mathbf{b}}$, com ocorrência em menor proporção de fácies similares com rizonconcreções $\left(\mathbf{A c}_{\mathbf{b}} \mathbf{r}_{\mathbf{a}} \mathrm{e} \mathbf{A c}_{\mathbf{a}} \mathbf{r}_{\mathbf{e}}\right.$ ), as quais não se observam na área de Macapá. As rizoconcreções foram observadas principalmente no topo das cristas achatadas de eolianito, em meio a estratificações de ângulo baixo que aparentemente acompanham a morfologia atual da feição (Figuras 6.16a e 6.20b, por exemplo) ou, mais raramente, cortando estratificações cruzadas de ângulo alto. Em Carnaubinha, diferenciaram-se dois tipos de eolianito, um tabular delgado (subcentimétrico), concordante com a morfologia atual do cordão, onde as rizoconcreções aparecem mais nítidas (Figura 6.16a); e outro espesso (métrico), em esculpimento pela deflação, e sem indícios de rizoconcreções, exceto porosidade em orifícios de diâmetro milimétrico. Em Macapá, a formação de crostas cimentadas é bem exemplificada: os eolianitos do topo apresentam maior cimentação que os mais profundos, os quais só exibem lentes delgadas (centimétricas) preferencialmente litificadas pelo cimento carbonático (Figura 6.18b).

A maioria dos histogramas circulares de azimutes de mergulho de estratificações cruzadas do setor norte, especialmente aqueles com elevado número de medidas (acima de 40), apresenta padrão bimodal, com moda principal S e secundária NW, nos cordões de eolianito transversais às praias de Carnaubinha, Macapá e Nova (Figuras 6.16d, 6.18c e $6.19 \mathrm{c}$ ), e moda principal NW e secundária $\mathrm{S}$, junto à praia de Maramar (Figuras 6.16c). Em todos estes casos, a orientação das cristas dos cordões de eolianito coincide com a bissetriz do ângulo entre as duas modas. Nos eolianitos da praia de Bitupitá e Maceió (Figura 6.19c e 6.21c), ambas com número mais baixo de medidas, a distribuição de azimutes resultou unimodal para NW. Assim, a nitidez e o equilíbrio entre as duas modas encontra-se nos histogramas com maior número de medidas, como bem demonstrado em Macapá (Figura 6.18c). Isto permite supor que a diferença de definição entre as modas, nos diferentes histogramas, decorra de um problema de representatividade estatística da amostragem de medidas. 


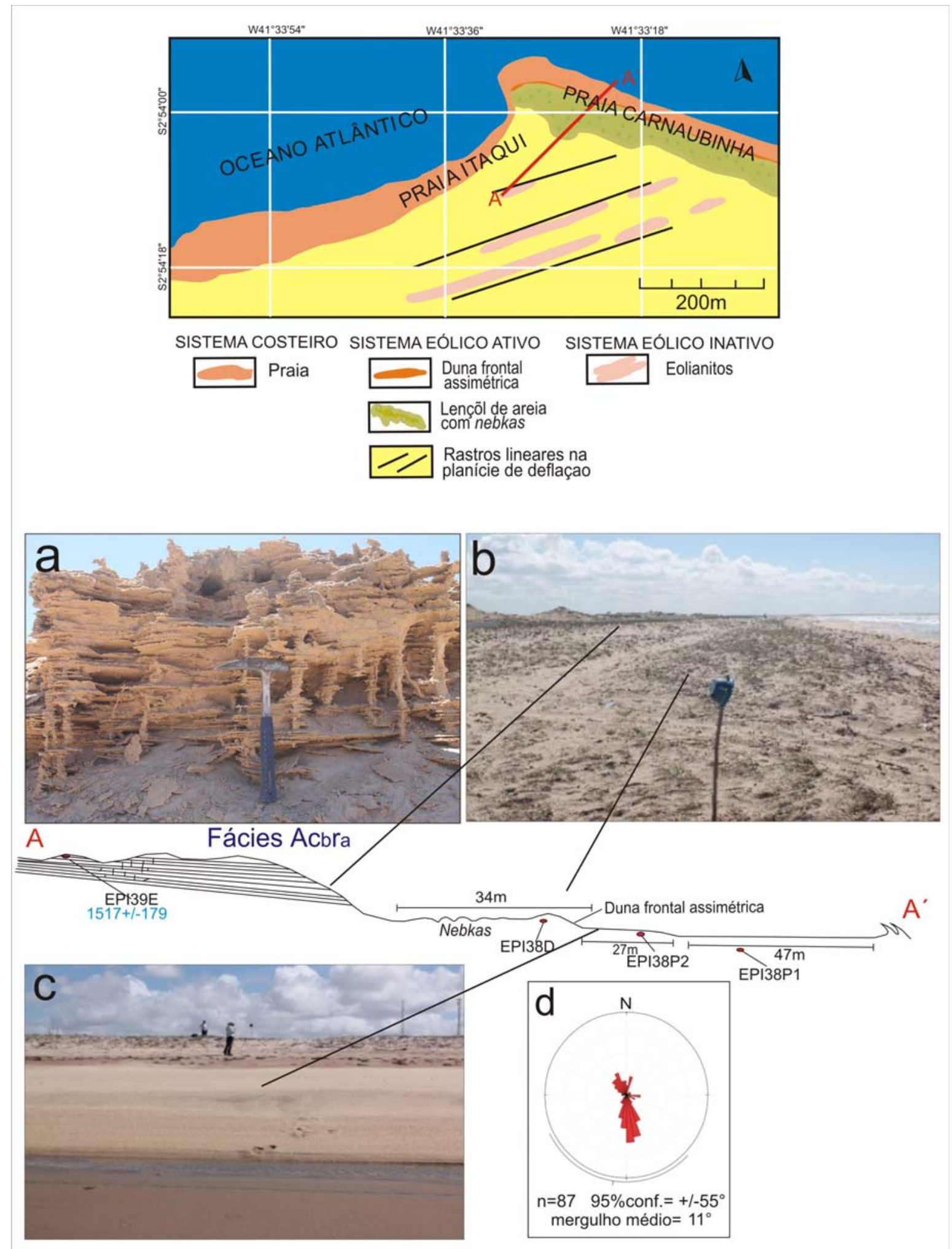

Figura 6.16. Distribuição de fácies morfológicas junto à praia de Carnaubinha, com indicação de amostras coletadas e datadas pelo LOE (legenda azuis) no corte A-A': a. fácies $\mathrm{Ac}_{\mathrm{b}} \mathrm{r}_{\mathrm{a}}$ de eolianito; b. duna frontal assimétrica e campo de nebkhas; c. praia dissipativa com terraço plano de baixa mar; e d. histograma circular de azimutes de mergulho de estratificações cruzadas em eolianitos, com padrão bimodal e moda principal rumo $\mathrm{S}$. 


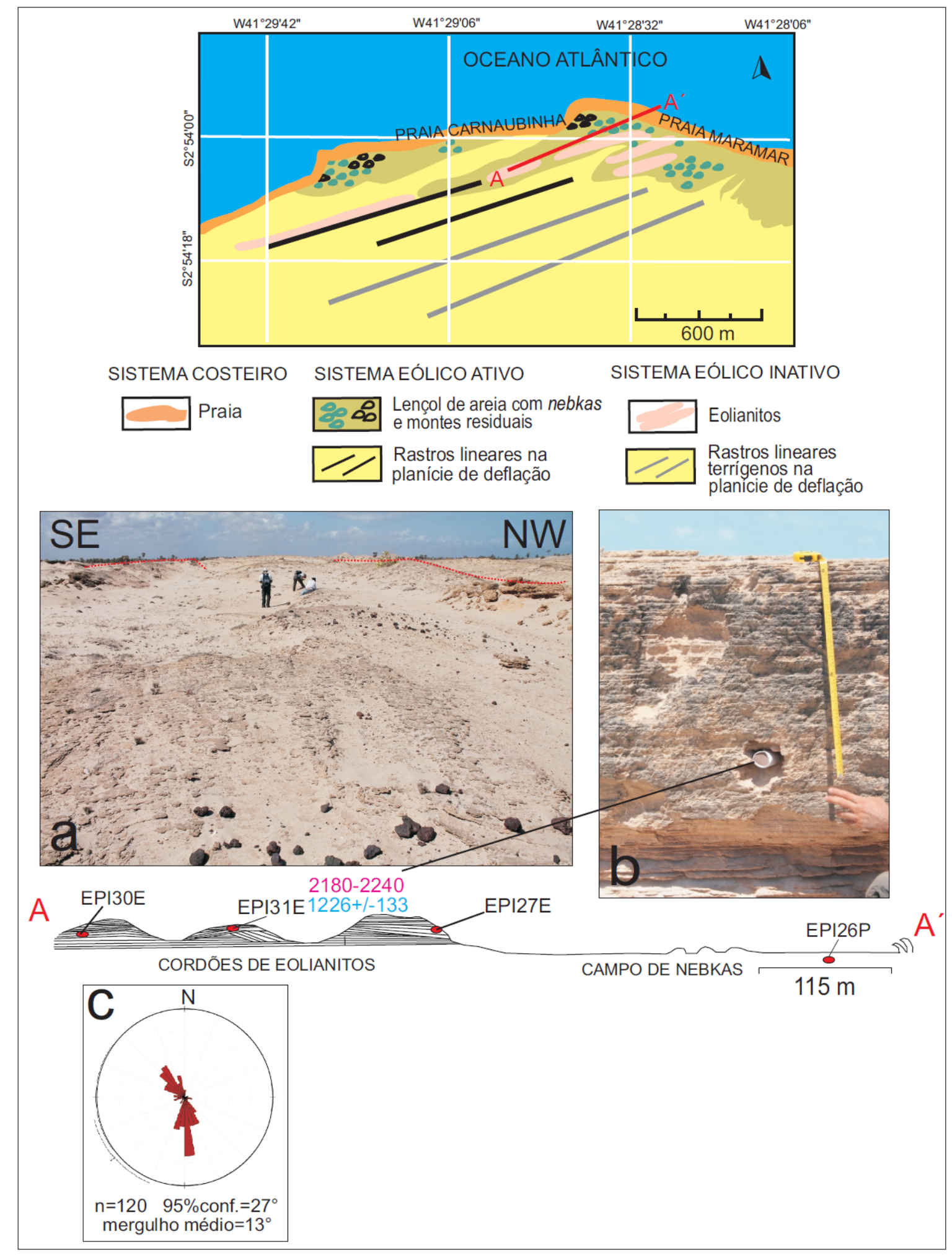

Figura 6.17. Distribuição das fácies morfológicas junto à praia de Maramar, com indicação de amostras coletadas e datadas pelo LOE (legenda azul) e por AMS em bioclastos (legenda rosa) no corte A- A': a. vista dos cordões de eolianito (tracejado vermelho), a partir de NE; $\mathbf{b}$. coleta de amostra para LOE na fácies $\mathrm{Ac}_{\mathrm{b}}$ do ponto EPI31E; e c. histograma circular de azimutes de mergulho de estratificações cruzadas em eolianitos, com padrão bimodal e moda principal para $S$. 


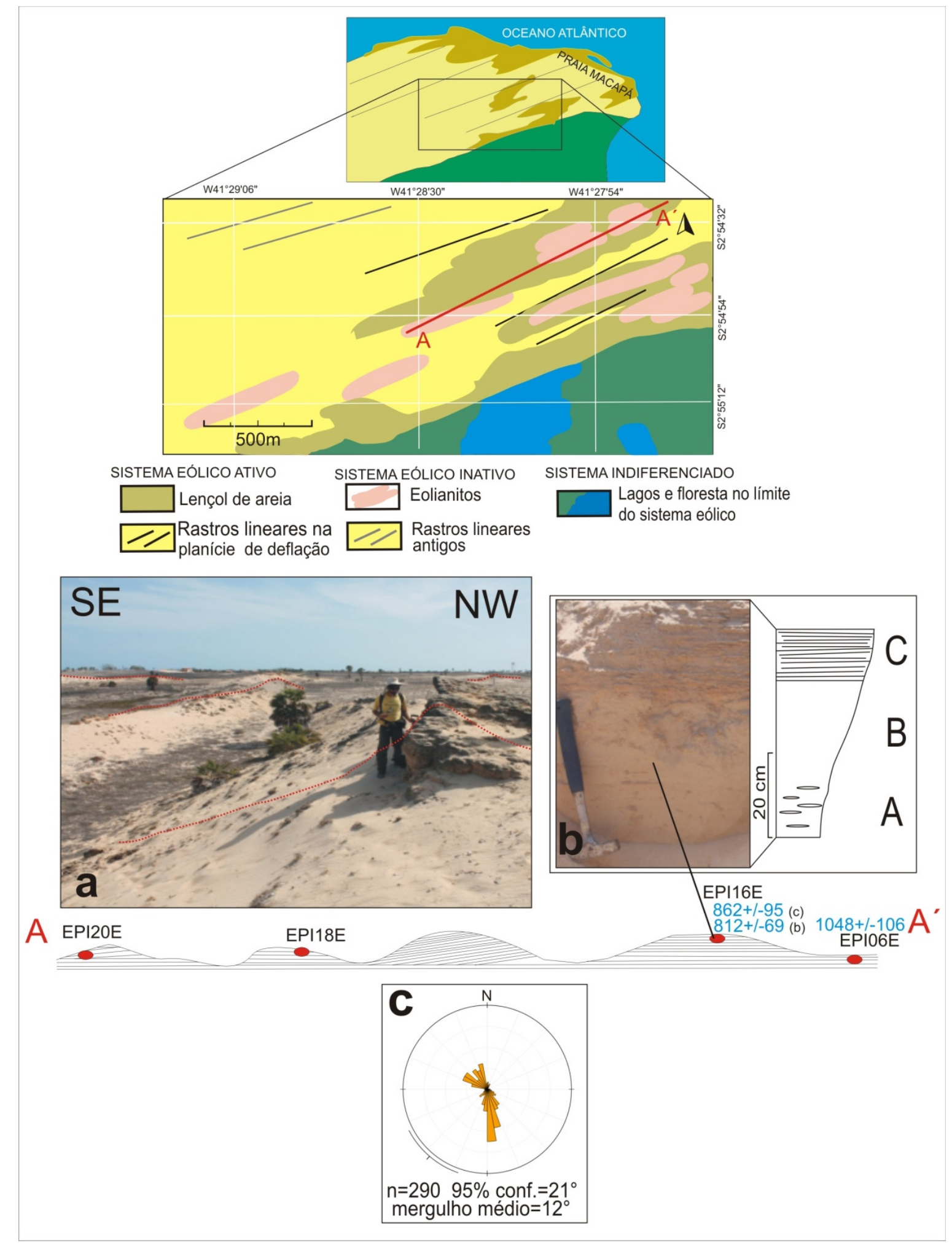

Figura 6.18. Distribuição das fácies morfológicas junto à praia de Macapá,com indicação de amostras coletadas e datadas pelo LOE (legenda azul) no corte A-A': a. vista perpendicular ao corte, mostrando os cordões de eolianitos; $\mathbf{b}$. fácies $A c_{b}$ do ponto EPI16E, em seção colunar onde A apresenta lâminas lenticulares de areia diferencialmente cimentadas, B horizonte de areia sem cimento e $\mathrm{C}$ horizonte mais cimentado; e c. histograma circular de azimutes de mergulho de estratificações cruzadas em eolianitos, com padrão bimodal para NNW a NW e SSE. 


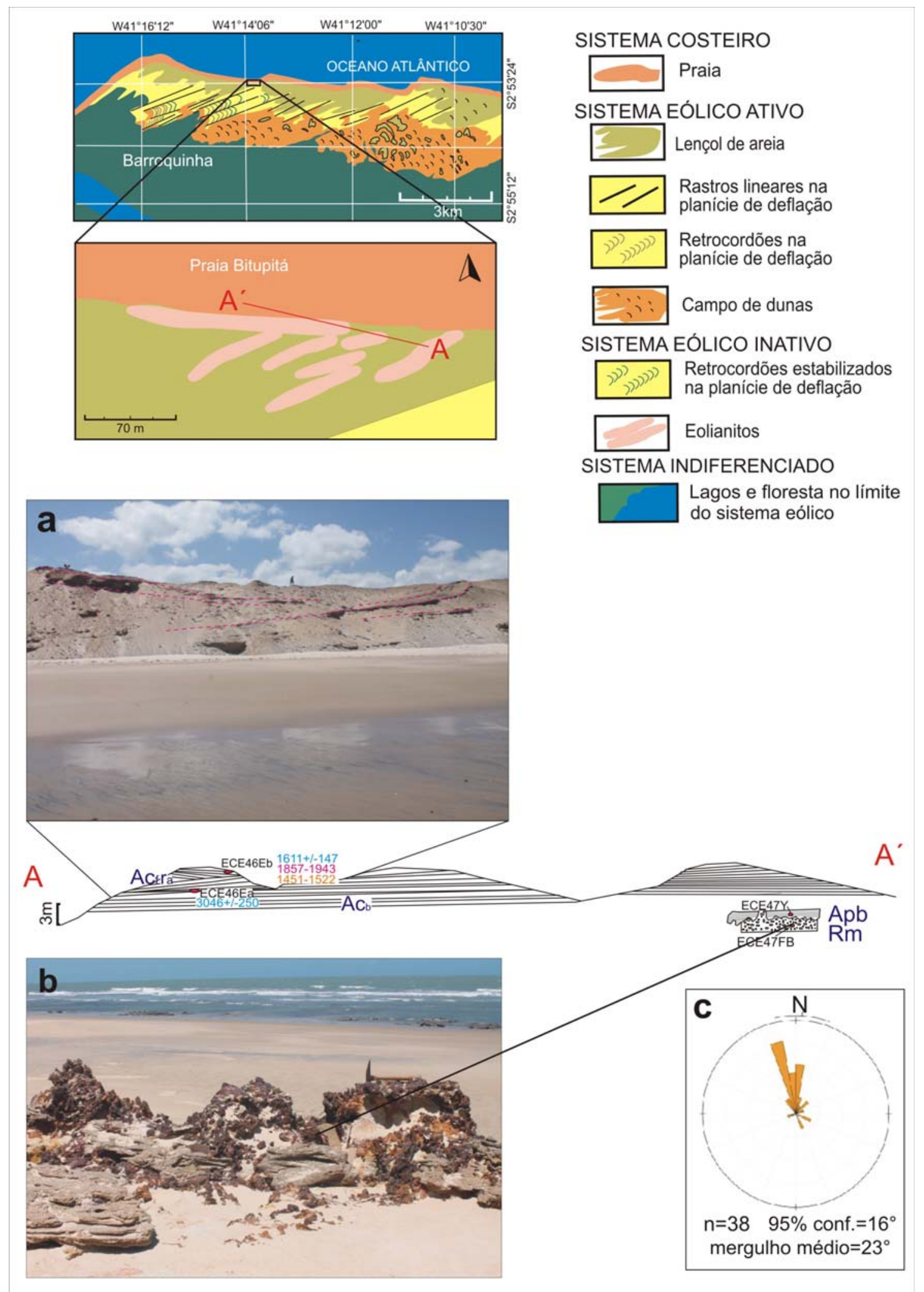

Figura 6.19. Distribuição das fácies morfológicas na área de Bitupitá, com indicação de amostras coletadas e datadas pelo LOE (legenda azul) e por AMS em bioclastos (legenda rosa) e cimento (legenda laranja) no corte A-A': a. falésia de eolianitos junto à praia, com exposição da fácies $\mathrm{Ac}_{\mathrm{f}_{\mathrm{a}}}$; b. amostra ECE47FB, fácies Rm (Formação Barreiras), e amostra ECE 47Y, fácies Apb (beach-rock); e c. histograma circular de azimutes de mergulho de estratificações cruzadas em eolianitos, com padrão unimodal NW. 


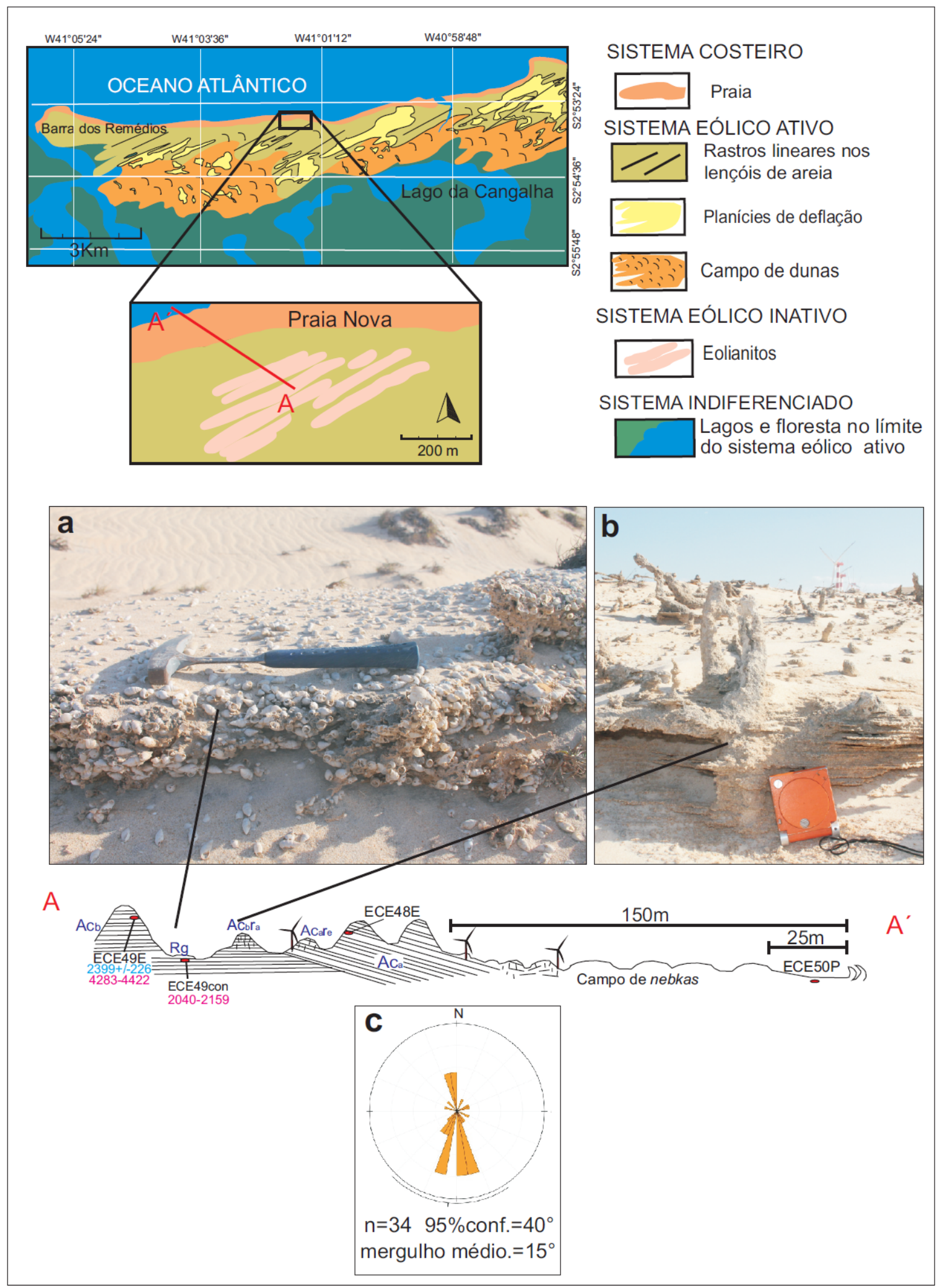

Figura 6.20. Distribuição das fácies morfológicas junto à praia Nova, no município de Camocim; o corte A-A' representa fácies e amostras coletadas e datadas pelo LOE (legenda azul) e por AMS em bioclastos (legenda rosa): a. amostra ECE49con, fácies Rmg; b. fácies de eolianito $\mathrm{Ac}_{\mathrm{b}} \mathrm{r}_{\mathrm{a}}$; $\mathbf{c}$. histograma circular de azimutes de mergulho de estratificações cruzadas em eolianitos, com padrão bimodal e moda principal rumo $\mathrm{S}$. 


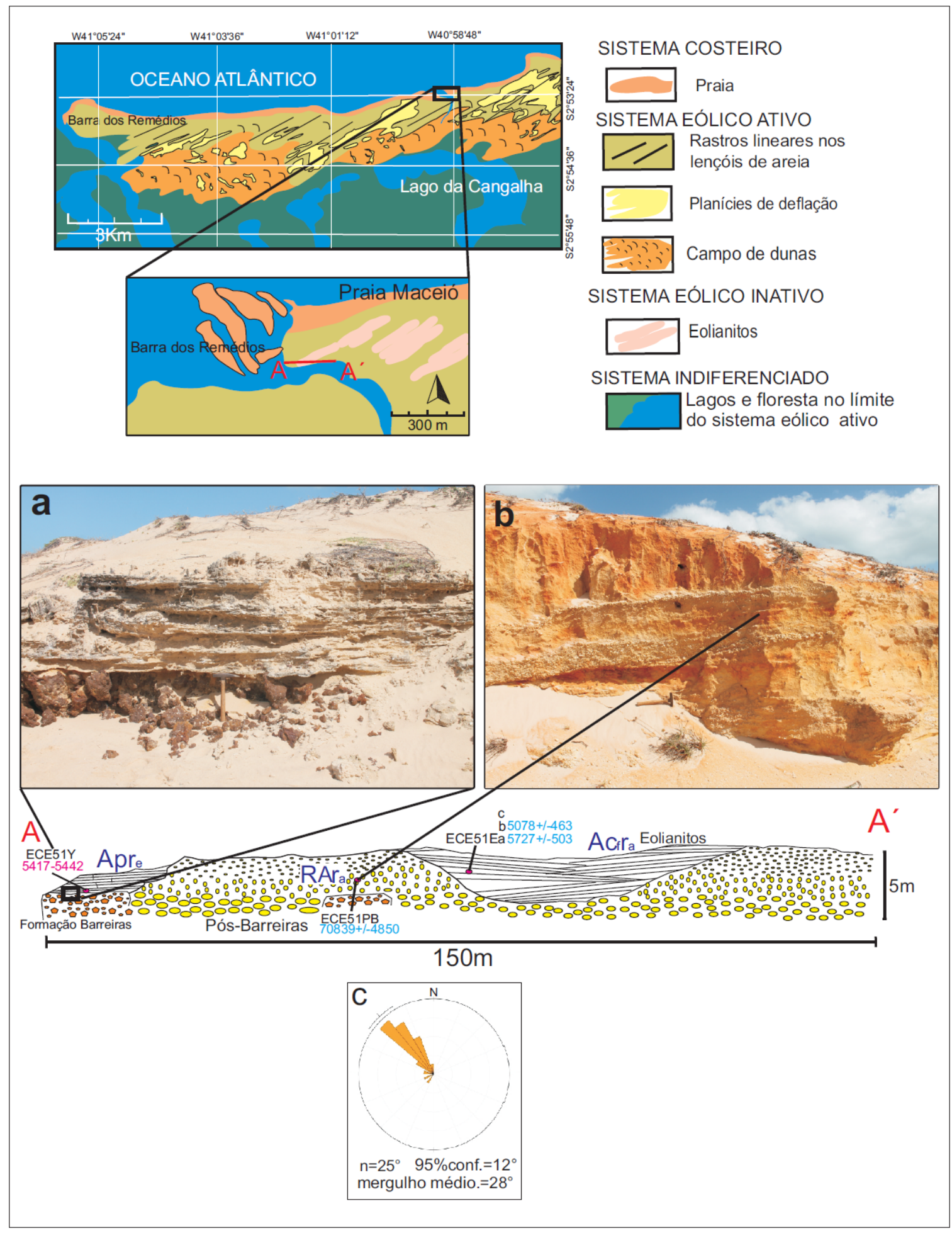

Figura 6.21. Distribuição das fácies morfológicas junto à praia Maceió, no município de Camocim; o corte A-A' representa fácies e amostras coletadas e datadas pelo LOE (legenda azul) e por AMS em bioclastos (legenda rosa): a. transição entre o beach-rock e os eolianitos (fácies $\mathrm{Apr}_{\mathrm{e}}$ ); b. "pósBarreiras", fácies $\mathrm{RAr}_{\mathrm{a}}$; e c. histograma circular de azimutes de mergulho de estratificações cruzadas em eolianitos, com padrão unimodal para NW. 
Outras fácies presentes no setor norte, e associadas aos sistemas eólicos quaternários estudados, foram correlacionadas estratigraficamente ao substrato e/ou à base dos eolianitos nas regiões de Luís Correia (PI) e Barroquinha-Camocim (CE).

No ponto EPI45, perto da Luís Correia (PI), observou-se sucessão de aproximadamente $1,5 \mathrm{~m}$ de espessura, composta da base para o topo por três fácies: Ap, com espessura de pelo menos 0,7m; Amg, com 0,5 m; e Am, com 0,3 m (Figura 6.22). A fácies Ap, com cor cinza, passa de modo transicional, via escurecimento gradual para cima, para Amg, a qual se distingue pela presença dos gastrópodes continentais (Pomacea $s p$.; Figura 6.22e.), com tamanhos desde 1 até $7 \mathrm{~cm}$. O aparecimento destes gastrópodes e o escurecimento ascendente são acompanhados pelo aumento da quantidade de carbonato, provavelmente na forma de cimento, da fácies Ap para a Amg. A fácies Am repousa discordantemente sobre o horizonte preto, endurecido e rico em carbonato do topo de Amg e caracteriza-se por areias médias cinza a bege, parcialmente consolidadas por cimento carbonático.Sucessão similar, porém mais espessa $(2,7 \mathrm{~m})$, foi encontrada no ponto EPI04, também nas proximidades de Luís Correia.

Nas áreas de Bitupitá, em Barroquinha, e de Camocim, pontos ECE47 e ECE51, respectivamente, os eolianitos repousam ora discordantemente sobre a fácies $\mathbf{R m}$ (Formação Barreiras) e a fácies $\mathbf{R A r}_{\mathbf{a}}$ (unidade areno-conglomerática basal do "pósBarreiras"), ora concordantemente sobre a fácies Apb (beach-rocks), podendo a sucessão aflorante com estas quatro unidades alcançar aproximadamente $5 \mathrm{~m}$ de espessura (Figura 6.23). A Formação Barreiras (fácies $\mathbf{R m}$ ), com as ferricretes características do seu intervalo estratigráfico superior, ocorre na base da sucessão, com espessuras aflorantes de 0,5 a 1,0 m. Segue-se, em contato discordante, o "pós-Barreiras" (fácies $\mathbf{R A r}$ ), com aproximadamente $2,5 \mathrm{~m}$, caracterizado pela interdigitação de areias e cascalhos em tons de vermelho e amarelo, com padrão geral granodecrescente para cima e presença no topo de rizoconcreções de menos de $1 \mathrm{~cm}$ de diâmetro e até $1 \mathrm{~m}$ de comprimento. Os beach-rocks (fácies Apb) ocorrem localmente, com espessuras entre 0,5 e 1m, em contato discordante sobre Rm, na forma dos arenitos conglomeráticos (até $25 \%$ de cascalho, inclusive bioclastos) da fácies Apb. A quantidade de cascalho cai gradualmente para cima, a interestratificação com camadas arenáceas torna-se evidente e rizoconcreções esparsas começam a aparecer na fácies $\mathbf{A p r}_{\mathbf{e}}$, a qual representa uma transição entre os beach-rocks (Apb) e os eolianitos típicos (fácies $\mathbf{A c}_{\mathbf{f}} \mathbf{r}_{\mathbf{a}}$ ). Estes são medianamente litificados e lateralmente, ocorrem também em contato discordante com a fácies $\mathbf{R A r}_{\mathbf{a}}$ ("pósBarreiras"). 


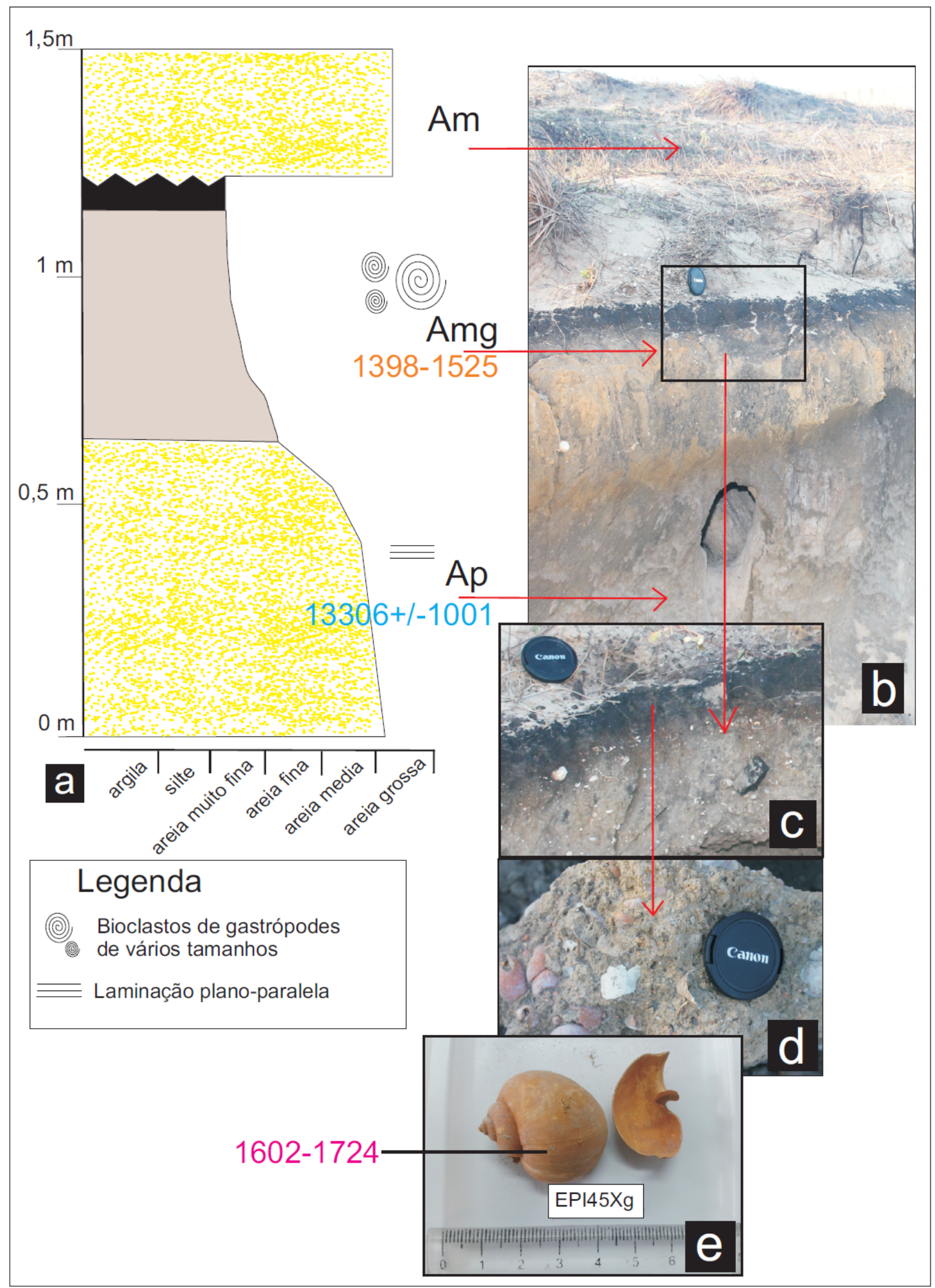

Figura 6.22. Coluna sedimentar correlacionada ao substrato dos eolianitos no ponto EPI45, próximo a Luís Correia: a. seção colunar esquemática com idades obtidas por LOE (legenda azul, em anos) e por AMS em cimento (legenda laranja, em anos cal A.P.); b. fotografia correspondente à seção colunar (a), com indicação das fácies deposicionais; c. detalhe da fácies Amg com transição acima de siliciclástico para calcário; $\mathbf{d}$. amostra bruta com detalhe de gastrópodos de 1 a $7 \mathrm{~cm} ; \mathrm{e}$ e. amostra de gastrópodes datados do gênero Pomacea (idade em anos cal A.P. indicada em rosa). 


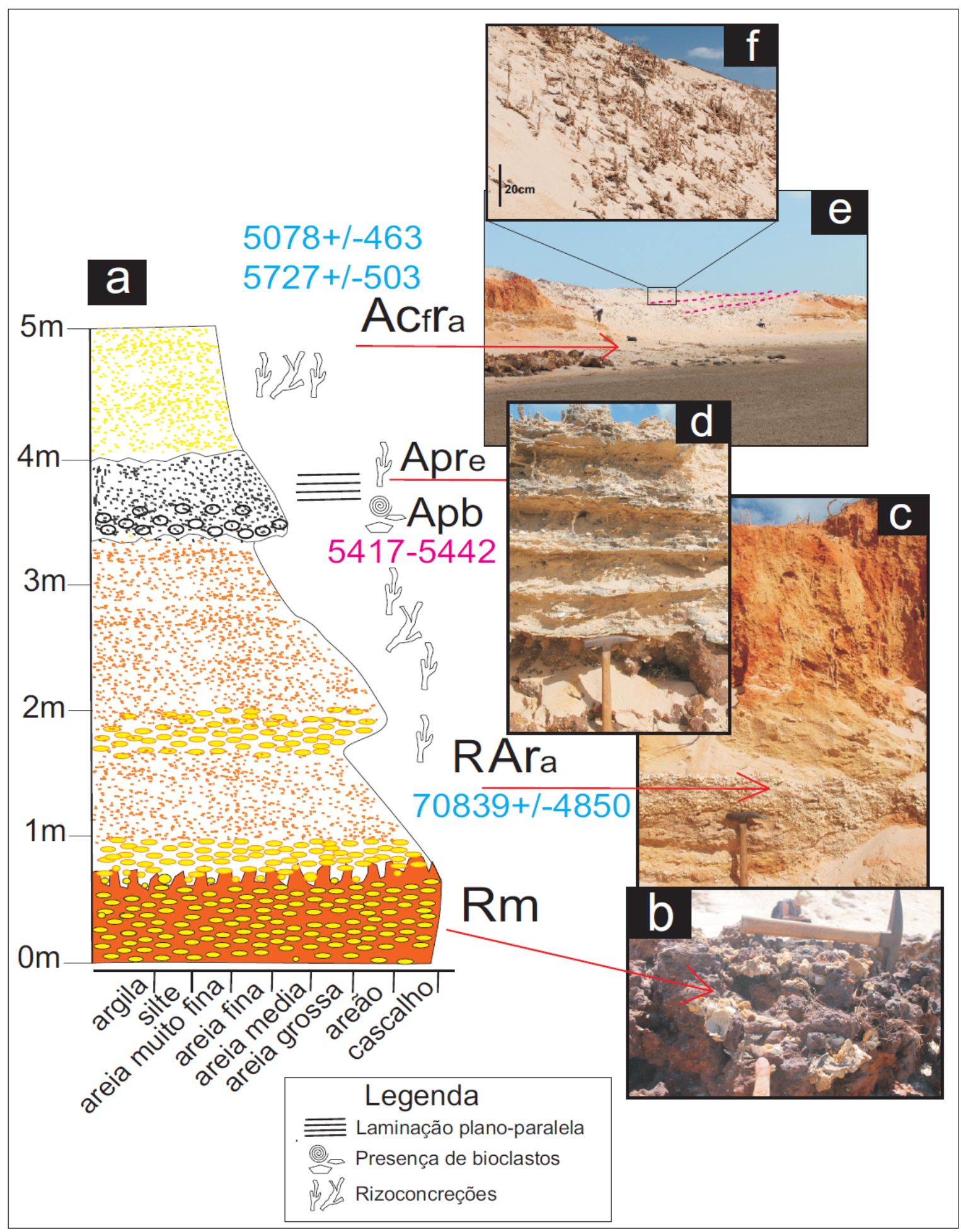

Figura 6.23. Eolianitos, e suas fácies associadas, observadas nos pontos ECE47 e ECE51, áreas de Bitupitá, em Barroquinha, e de Camocim, com as idades obtidas por LOE (legenda azul, em anos) e por AMS em bioclastos (legenda rosa, em anos cal A.P.): a. seção colunar de fácies composta (integrando todas as exposições dos dois pontos); b. rudito maciço com ferricretes (Rm), correspondente à Formação Barreiras; c. "pós-Barreiras", com alternância de rudito maciço e arenito maciço com rizoconcreções abundantes (fácies $\mathrm{RAr}_{\mathrm{a}}$ ); d. arenito com estratificação decimétrica marcada por concentrações de bioclastos rudáceos, laminação interna plano-paralela e rizoconcreções escassas $\left(\mathrm{Apr}_{\mathrm{e}}\right)$; e. eolianitos com laminação cruzada acanalada-festonada e rizoconcreções abundantes $\left(\mathrm{Ac}_{\mathrm{f}} \mathrm{r}_{\mathrm{a}}\right)$, estas vistas em zoom-in em $\mathbf{f}$. 


\subsubsection{Setor centro}

No setor centro, foram visitados eolianitos em Itarema e Almofala. Os eolianitos de Itarema consistem de quartzoarenitos com bioclastos, tamanho fino a médio (2.2 ), contendo rizoconcreções escassas (fácies $\mathbf{A c}_{\mathbf{a}} \mathbf{r}_{\mathbf{e}}$ ), concentradas num horizonte mais rico em conchas (Figura 6.24); um paleossolo arqueológico, com restos de fogueira, separa esta fácies, abaixo, das areias finas a médias não consolidadas (fácies Am), acima.

Os eolianitos de Almofala, com espessura visível de mais de $3 \mathrm{~m}$, e centenas de metros de extensão ao longo de falésia costeira, correspondem a quartzoarenito fino a grosso (1.7 ) com bioclastos e séries decimétricas a submétricas de estratificações cruzadas (fácies $\mathbf{A c}_{\mathbf{a}}$ ). O padrão morfológico das estratificações, com alternância lateral de convexidades e concavidades, sugere a relação com antigas blowouts ou dunas parabólicas cortadas pela linha de costa em erosão (Figura 6.25b).

Os histogramas circulares de azimutes de mergulho de estratificações cruzadas do setor centro apresentam padrão unimodal SSW a SW, em Itarema, e bimodal, com moda principal $\mathrm{S}$ e secundária $\mathrm{NE}$, junto à praia de Almofala. A exemplo do observado no setor norte, o padrão unimodal associa-se ao menor número de medidas (26, no afloramento mais restrito de Itarema, contra 74 no extenso afloramento em falésia de Almofala).

\subsubsection{Setor sul}

Os eolianitos do setor sul apresentam granulometria areia grossa a média ( 0,8 e 2,2 ) e rizoconcreções longas ( $>10 \mathrm{~cm}$ ), que podem ser abundantes (fácies $\mathrm{Ac}_{\mathrm{b}} \mathrm{r}_{\mathrm{a}}$ e $A \mathrm{Apr}_{\mathrm{a}}$ ) ou raras e dispersas (fácies $\mathrm{Ac}_{\mathrm{a}} \mathrm{r}_{\mathrm{e}}$ ). Porosidade e rugosidade milimétricas de padrão dendrítico, observadas sobretudo nas cruzadas de ângulo baixo em Guajiru, lembram raízes pequenas. Junto à praia de Piriquara, concreções de carbonato, sejam ocas (em meia esfera), sejam rizolíticas verticais e horizontais, associam-se preferencialmente às estratificações de mergulho baixo.

Os histogramas circulares de azimutes de mergulho de estratificações cruzadas apresentam, em Trairi, padrão bi a polimodal, mas com presença recorrente das modas S e N (Figura 6.26c e 6.27c); e, em Paracuru, padrão polimodal, com modas NE, SW, SSE e WNW (Figura 6.28d). 


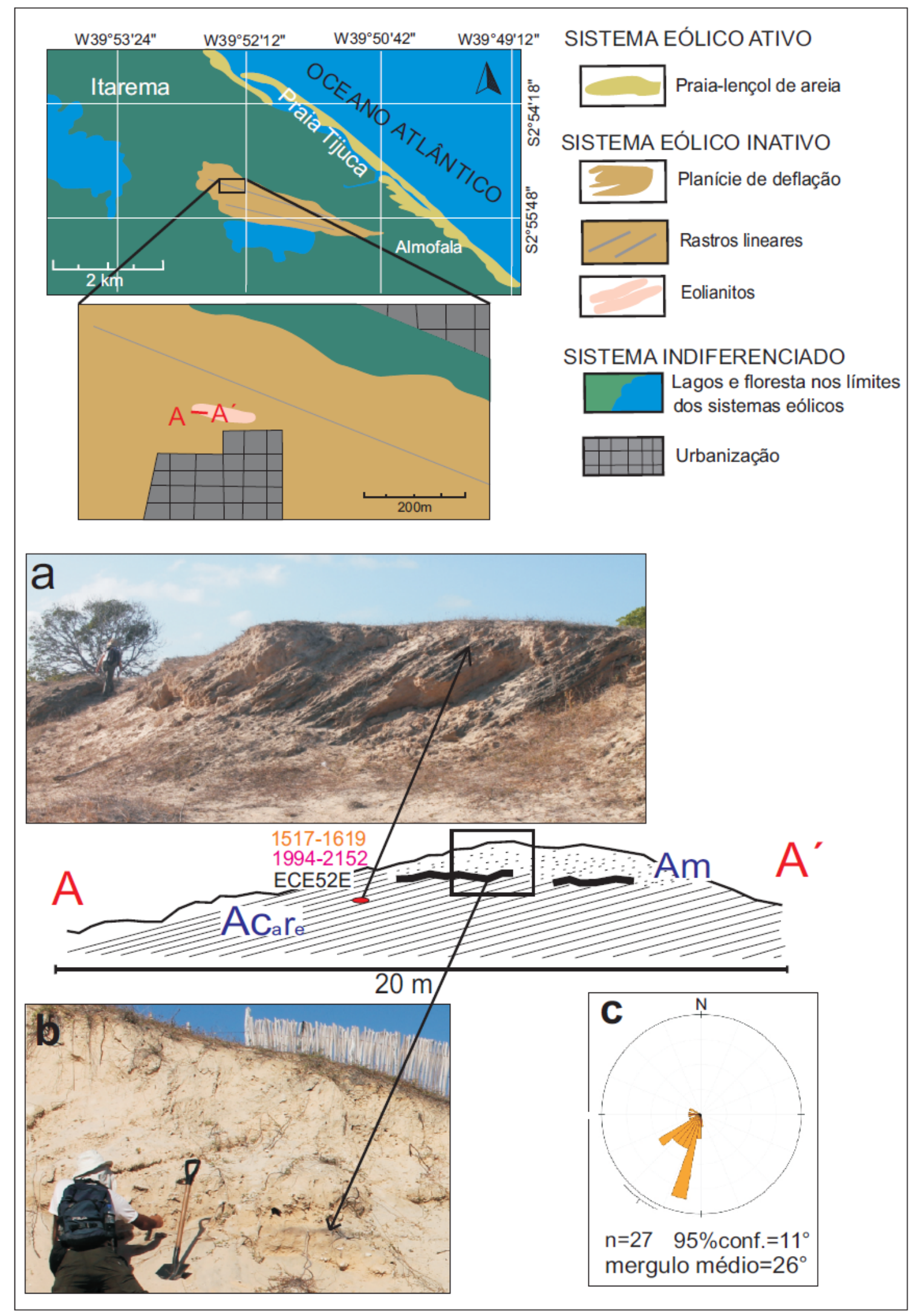

Figura 6.24. Distribuição das fácies morfológicas e do cordão de eolianito na área de Itarema, com indicação da amostra coletada e datada por AMS em bioclastos (legenda rosa, em anos cal A.P.) e em cimento (legenda laranja) no corte $\mathrm{A}-\mathrm{A}^{\prime}$ : a. panorâmica do afloramento, com exposição da fácies $\mathrm{Ac}_{\mathrm{a}} \mathrm{r}_{\mathrm{e}}$; b. fogueira sob a fácies Am; e c. histograma circular de azimutes de mergulho de estratificações cruzadas, com padrão unimodal para SW a SSW. 


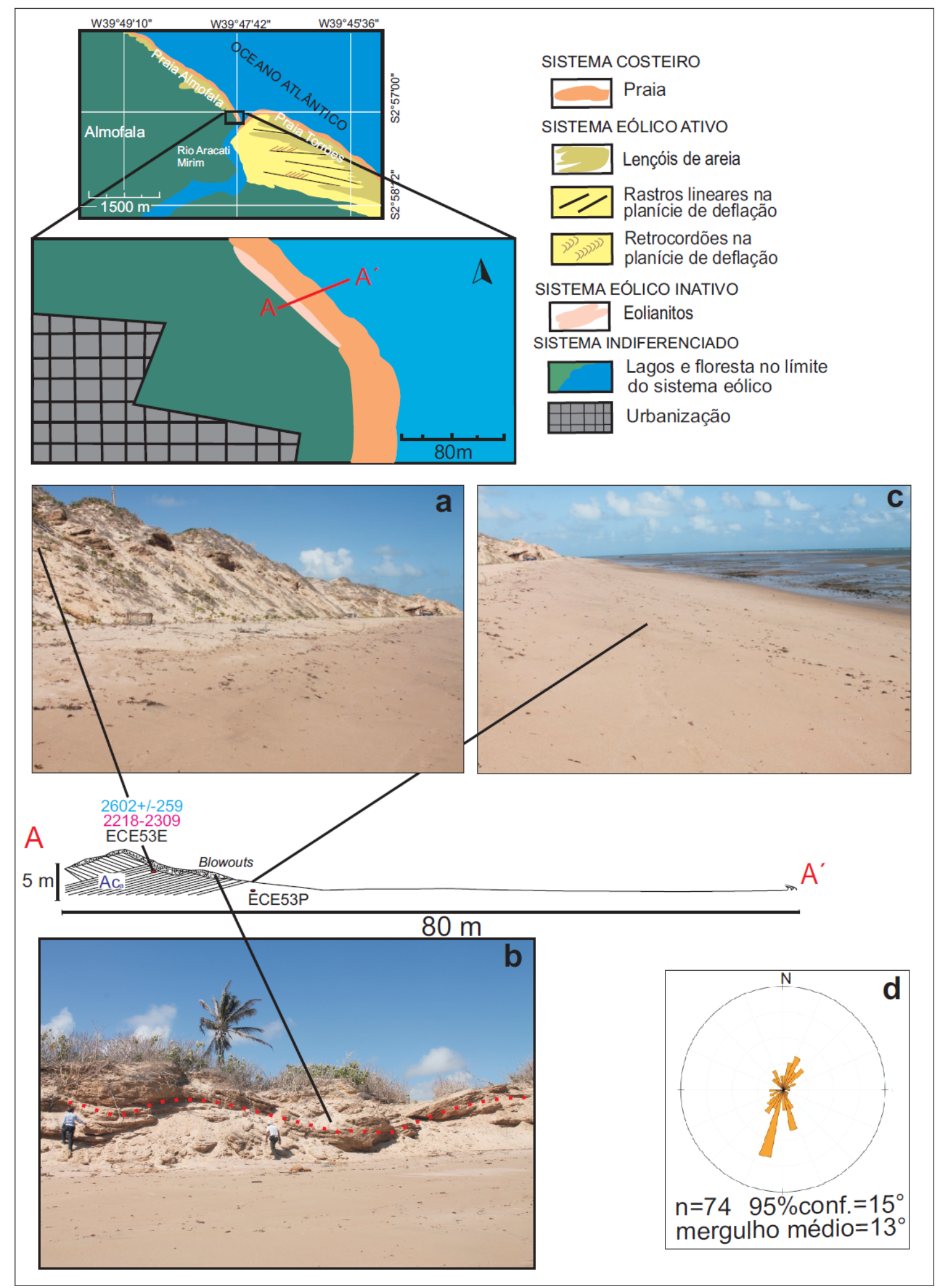

Figura 6.25. Distribuição das fácies morfológicas e do cordão de eolianitos junto à porção sudeste da praia de Almofala, com indicação das fácies, amostras coletadas e datadas por LOE (legenda azul, em anos) e por AMS em bioclastos (legenda rosa, em anos cal A.P.) no corte A-A: a. panorâmica do afloramento subparalelo à praia; b. blowouts ou dunas parabólicas cortados pela linha de costa em erosão; c. vista da praia dissipativa, com amplo terraço de baixamar; e d. histograma circular de azimutes de mergulho de estratificações cruzadas, com padrão bimodal e moda principal para $\mathrm{S}$. 


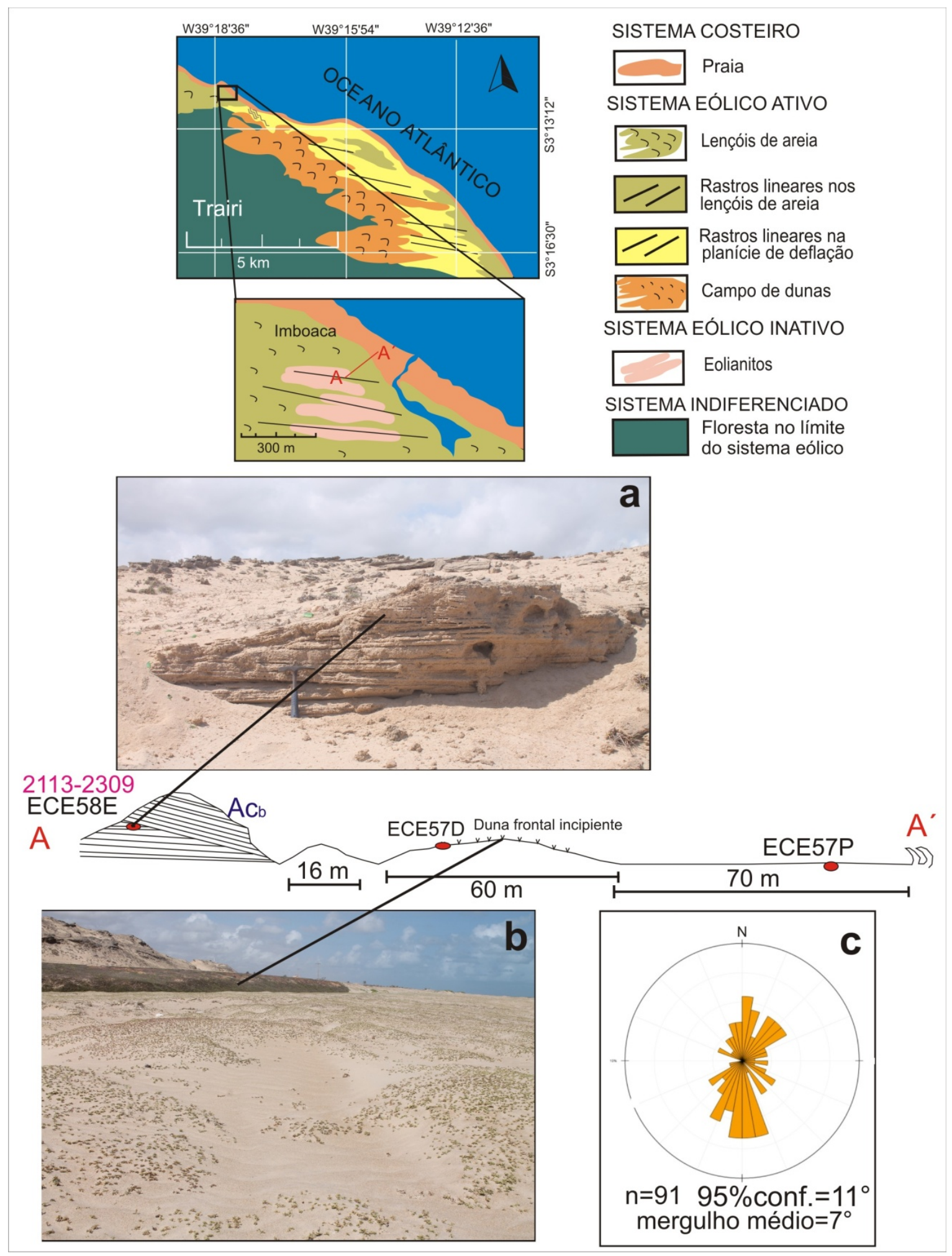

Figura 6.26. Distribuição das fácies morfológicas e dos corpos de eolianito junto à praia de Imboaca (corte A-A') município de Trairi, com indicação de fácies deposicionais, amostras coletadas e datadas por AMS em bioclastos (legenda rosa, em anos cal A.P.): a. local de coleta da amostra ECE58, fácies $\mathrm{Ac}_{\mathrm{b}}$; $\mathbf{b}$. duna frontal incipiente, com afloramentos de eolianito ao fundo; $\mathbf{c}$. histograma circular de rumos de mergulho de estratificação, com padrão bimodal. 


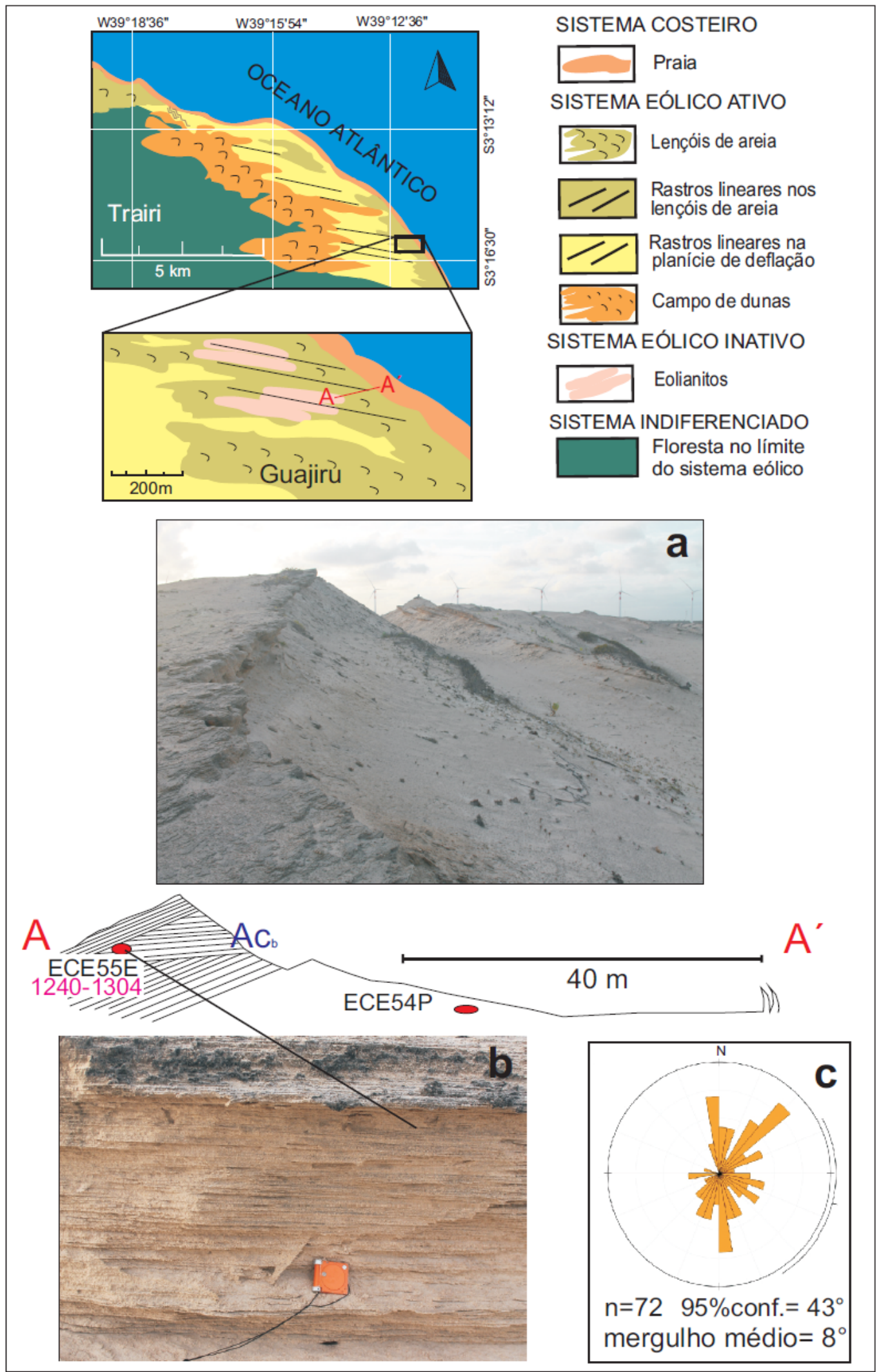

Figura 6.27. Distribuição das fácies morfológicas e dos corpos de eolianito junto à praia de Guajiru (corte A-A') município de Trairi, com indicação de fácies deposicionais e de amostras coletadas e datadas por AMS em bioclastos (legenda rosa, em anos cal A.P.): a. panorâmica dos cordões de eolianitos; b. local de coleta da amostra ECE55E, fácies $\mathrm{Ac}_{\mathrm{a}}$; $\mathbf{c}$. histograma circular de rumos de mergulho de estratificação, com padrão trimodal N, NE e S. 


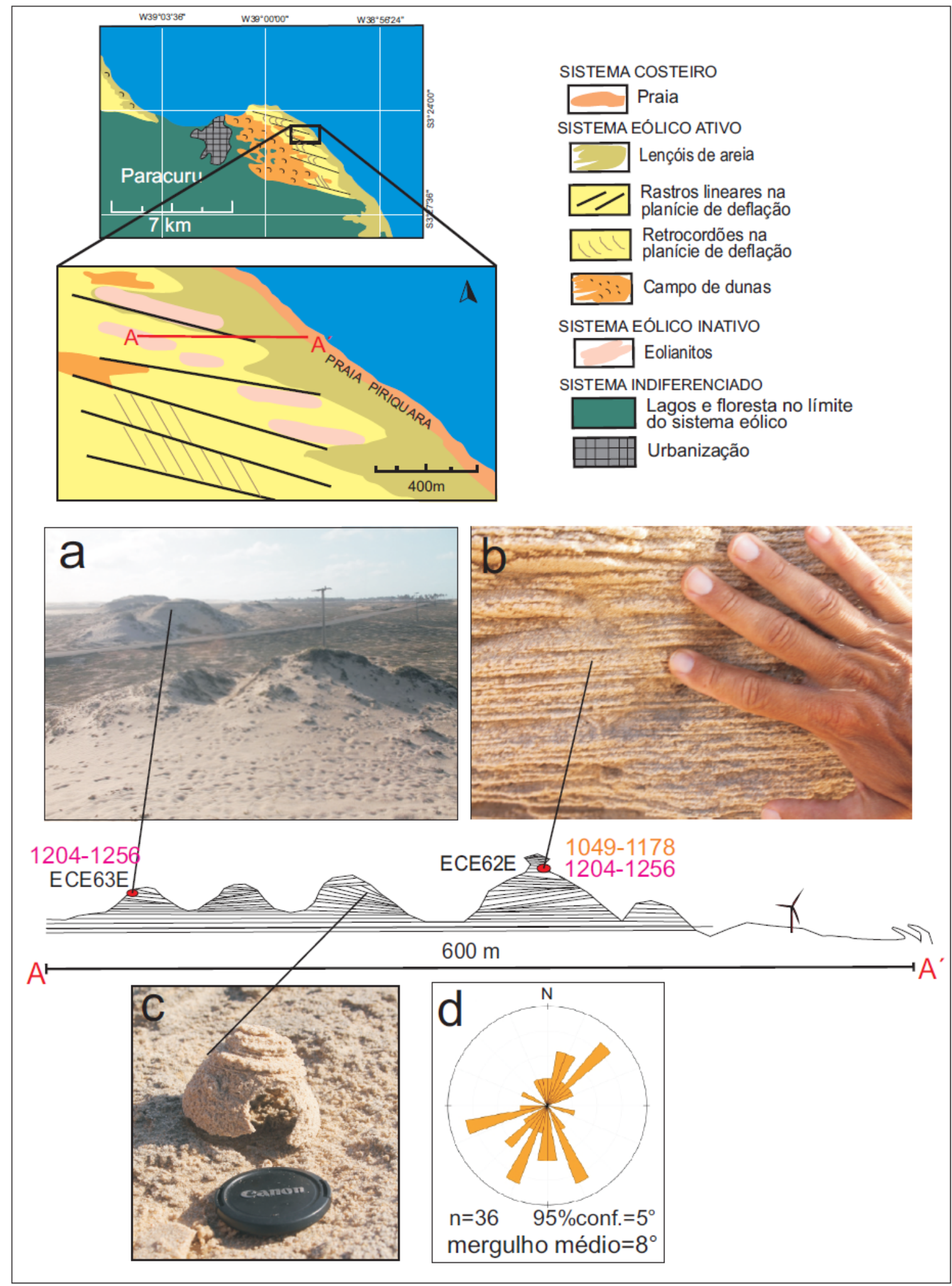

Figura 6.28. Distribuição das fácies morfológicas e dos corpos de eolianito junto à praia de Piriquara, em Paracuru, com indicação das amostras coletadas e datadas por AMS em bioclastos (legenda rosa em anos cal A.P.) e em cimentos (legenda laranja) no corte A-A': a. panorâmica dos cordões de eolianitos e localização da amostra ECE63E; b. amostra ECE62E, fácies $A c_{b}$; $c$. concreções de carbonato em meia esfera; d. histograma circular de azimutes de mergulho de estratificações cruzadas, com padrão polimodal. 


\subsubsection{Distribuição de fácies deposicionais no tempo}

A integração dos resultados de análise de fácies (item 6.1.3) com as idades obtidas nos eolianitos (item 6.1.2) está sintetizada no diagrama em caixa da Figura 6.29, onde se representaram apenas as quatro fácies mais comuns: $\mathbf{A} \mathbf{c}_{\mathbf{a}}, \mathbf{A} \mathbf{c}_{\mathbf{b}}, \mathbf{A c}_{\mathbf{b}} \mathbf{r}_{\mathbf{a}}$ e $\mathbf{A c}_{\mathbf{f}} \mathbf{r}_{\mathbf{a}}$. As fácies $\mathbf{A c}_{\mathbf{a}}$ e $\mathbf{A c}_{\mathbf{b}}$, apesar de em maior número (n) de ocorrências e com distribuição em todos os setores geográficos da área em estudo, apresentam intervalo interquartis mais restrito que as demais. Este intervalo é também quase inteiramente mais novo, variando entre cerca de1000 e 2200 anos, com $\mathbf{A c}_{\mathbf{b}}$ apresentando tendência para idades ligeiramente mais jovens que $\mathbf{A c}_{\mathbf{a}}$.

A fácies $\mathbf{A c}_{\mathbf{b}} \mathbf{r}_{\mathbf{a}}$, correspondente a amostras obtidas nas áreas de Itaqui (Luís Correia) e Praia Nova (Camocim), no setor norte, possui intervalo de variação total (1600 a 4200 anos) contido no intervalo interquartis da fácies $\mathbf{A c}_{\mathbf{f}} \mathbf{r}_{\mathbf{a}}$ (1600 e 5300 anos), relativa às áreas de Bitupitá e Maceió, também do setor norte.

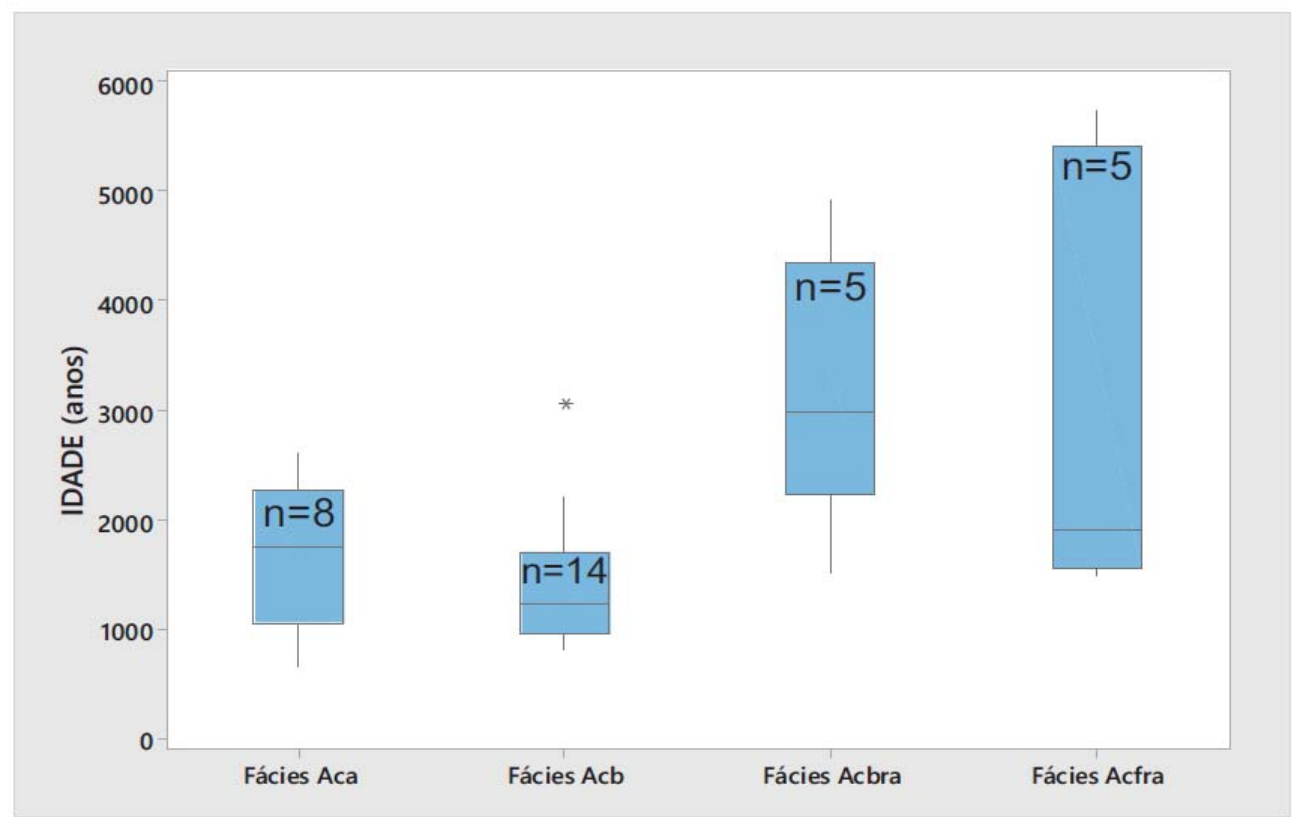

Figura 6.29. Diagrama em caixa de idades de eolianitos, por fácies deposicional. Para a construção do gráfico, foram consideradas as idades medianas.

\subsection{Discussão}

\subsubsection{Controles de formação e distribuição espacial dos eolianitos}

A ocorrência de eolianitos de modo geral é determinada por um controle passivo ou de fonte, a disponibilidade de carbonatos na plataforma continental interna adjacente; e por um controle ativo, este subdividido em dois fatores: a ação de ondulações com competência e capacidade para mobilizar em direção à costa os clastos carbonáticos da 
plataforma; e, em seguida, a atuação efetiva do vento sobre o substrato costeiro carbonático, que deve estar em estado incoesivo, portanto livre de umidade. Entra aí a influência do fator climático. O clima quente e seco favorece a formação de eolianitos (McKee \& Ward 1983) em três momentos da história sedimentar: na constituição da plataforma calcária, já que a baixa precipitação reduz o aporte terrígeno e a turbidez das águas, e assim amplia a comunidade bentônica geradora de carbonatos; na efetividade do vento como agente de transporte, necessária para a formação de dunas; e na precipitação química do carbonato por evaporação durante a diagênese precoce, requerida para a consolidação do eolianito. Além da questão da alta evaporação, a influência do clima na formação de eolianitos estende-se à questão da intensidade e orientação do vento, o que controla tanto a iniciação de sistemas eólicos na costa quanto à orientação e energia das ondulações (swells) costa afora, estas responsáveis pela erosão da plataforma continental interna onde se encontram os principais componentes carbonáticos do arcabouço dos eolianitos analisados (algas vermelhas e foraminíferos bentônicos).

Sendo assim, a presença prévia ou contemporânea de fácies carbonáticas na plataforma continental é um fator primordial na formação de eolianitos e que ajuda a explicar a distribuição das suas ocorrências no Nordeste brasileiro em escala regional. Na costa continental nordestina, os eolianitos desaparecem a W, no Estado do Maranhão, e, a E, a partir de Fortaleza, CE, onde a representatividade de fácies carbonáticas na plataforma cai (Maia 1998). A região de maior concentração de eolianitos, que vai de Luís Correia (PI) a Mundaú (CE), coincide assim com a distribuição do domínio carbonático nas plataformas interna e/ou média e também com a de algas coralíneas ramificantes (Kowsmann \& Costa 1979; Figura 2.6). Esta distribuição do domínio carbonático, por sua vez, depende de uma conjunção complexa de variáveis fisiográficas e ecológicas. Merece destaque o fato de que esta é a região de plataforma interna mais larga e suave no trecho de costa E-W a WNW situado a barlamar (leste) da foz do rio Parnaíba e da baía de São Luiz, e, portanto livre da influência dos dois focos regionais mais importantes de aporte terrígeno.

Em escala global, a influência do clima na conjunção de baixo aporte terrígeno com clima quente e pouco úmido expressa-se na concentração de eolianitos nas faixas de média latitude (Brooke 2001). Os eolianitos em estudo, porém, estão fora deste modelo, já que se situam em latitude baixa. O que determina a redução de umidadenesta área a ponto de permitir a formação de eolianitos é a sua posição quaseà margem da faixa de umidade equatorial representada pela ZCIT. A região situa-se aproximadamente no limite sul de alcance médio desta zona, que acontece no verão, e permanece a parte restante do ano com poucas chuvas.

Outra importância da localização da área na margem sul da ZCIT reside na convergência dos ventos alísios do NE e de SE que caracteriza esta região e que determina o aporte eólico onshore. Com isso, ao longo da costa do Piaú e Ceará, tem-se a passagem gradual, rumo sul, do domínio de ventos alísios de NE para o domínio dos de SE. O setor norte da área de estudo associa-se a zona de alísios de NE do Anticiclone do Atlântico Norte, mais atuante na estação chuvosa, enquanto o setor sul encontra-se mais sob influência da zona de alísios de SE do Anticiclone do Atlântico Sul, atuante sobretudo durante a estiagem (Giannini et al. 2005). Esta situação gera três direções de avanço de 
campos de dunas na região: para SW, no setor norte; para $\mathrm{W}$, no setor centro; e para WNW, no setor sul.

As variações de orientação do vento efetivo, conjugadas com as de direção da linha de costa, determinam o desenvolvimento e as dimensões do sistema eólico e das suas feições morfológicas constituintes, em cada trecho do litoral. Nos trechos onde a direção do vento efetivo é mais próximo da perpendicularidade à linha de costa, o sistema eólico alcança maiores distâncias a partir de sua área fonte na praia. Com isso, a planície deflacionária alonga-se e torna-se dominante em relação às associações de elementos morfológicos de caráter mais deposicional (praia-duna e campo de dunas), apresentando desenvolvimento extenso ou conspícuo de feições como rastros residuais lineares, retrocordões e dunas parabólicas; inversamente, na medida em que a direção do vento se torna mais oblíqua (ângulos tão baixos quanto $30^{\circ}$ ) à linha de costa, o estoque de areia eólica concentra-se mais perto da praia, o sistema torna-se mais saturado de sedimentos, a planície deflacionária fica mais curta e as zonas deposicionais passam a ser dominantes em área. É em meio às zonas deflacionárias ativas que se localiza a grande maioria dos eolianitos, em cordões alinhados com os rastros lineares residuais e com a direção do vento efetivo atual.

O setor norte apresenta vento efetivo de NE para SW a ENE para WSW quanto à direção da linha de costa, divide-se em duas porções: a primeira corresponde ao litoral do Piauí (Itaqui, Carnaubinha e Macapá) onde o ângulo vento-costa varia de $45^{\circ}$ a $60^{\circ}$ e a zona deflacionária, com até 7,5 $\mathrm{km}$ de comprimento, é maior em área que as zonas deposicionais; a segunda porção do setor norte abrange as áreas do extremo oeste do Ceará (Bitupitá, Praia Nova e Maceió), onde a linha de costa é oblíqua, com ângulo de apenas $30^{\circ}$ em relação do vento, e a zona deflacionária encurta-se para menos de $2,5 \mathrm{~km}$; os cordões de eolianitos passam a ocorrer próximos à costa, cobertos por lençóis de areia da parte proximal do sistema ativo (associação praia-duna).

Já o setor centro apresenta orientação aproximada de vento efetivo de E para W, evidenciada nos rastros lineares de sua zona deflacionária, levemente apagada e apresentando um ângulo vento-costa de aproximadamente $30^{\circ}$. Esta região caracteriza-se pela ausência de campos de dunas ativos, e, analisada em imagens de satélite, mostra duas feições particulares que podem explicar este fenômeno: primeiro, o consumo de estoque de areia com a progradação longitudinal de um esporão na forma de ilha barreira; e, segundo, a presença de lagunas costeiras atrás desta ilha, sugerindo que parte do estoque de areia do sistema foi afogado e/ou teve seu trânsito interrompido.

O setor sul possui rumo de vento efetivo de ESE para WNW, obliquo à linha de costa em ângulo de $35^{\circ}$ a $45^{\circ}$, o que implica zona deflacionária com extensão intermediária (até 5 $\mathrm{km}$ ); os cordões de eolianitos encontram-se alguns na zona deflacionária, paralelos aos rastros lineares residuais, outros parcialmente cobertos por lençóis de areia próximos à praia.

$\mathrm{Na}$ classificação dos tipos ou estágios de sistemas eólicos costeiros brasileiros, proposta por Giannini (2007) e Giannini et al. (2011, 2014), a área em estudo abarca desde o tipo 3 até o 7 (Figura 6.30). Nos setores sul e norte, tem-se predomínio dos tipos 6, em que as três associações de fácies ou de elementos morfológicos (praia-duna, planície de deflação e campo de dunas livres: A, B e C na Figura 6.30) ocorrem, sendo a associação 
campo de dunas formada por barcanas, barcanoides e cordões de precipitação, com ausência ou pobre desenvolvimento de lobos deposicionais. Já o setor centro é dominado pelo tipo 4, sem campo de dunas mas com dunas parabólicas isoladas, e pelo tipo 5, em que o campo de dunas limita-se a parabólicas coalescidas, sem definição clara de dunas barcanas e cadeias barcanoides (Figura 6.30). Os tipos ou estágios desta classificação representam, de 1 a 8, aumento progressivo do saldo eólico relativo, isto é, da razão entre o saldo absoluto de sedimentos eólicos (influxo menos efluxo, diretamente proporcional à relação entre aporte e energia do vento) e o espaço de acumulação eólica (Giannini 2007, Giannini et al. 2014). Desse modo, a classificação morfodinâmica dos sistemas eólicos costeiros da área em estudo reforça a ideia de maior saldo ou saturação eólica nos setores sul e norte de que no setor centro. A escassez de areia eólica no setor centro está provavelmente ligada ao subparalelismo entre o rumo de avanço das frentes de ondulações mais atuantes e a linha de costa, o que gera forte trânsito de sedimentos litorâneos, com formação de sistemas progradantes de esporões de deriva. A porção piauiense do setor norte, apesar de contar com planícies de deflação mais extensas, por efeito da subperpendicularidade entre vento e costa, tem o mesmo grau de saturação que o setor sul, já que se situa mais a sotamar, portanto no polo deposicional, da deriva litorânea longitudinal regional. 


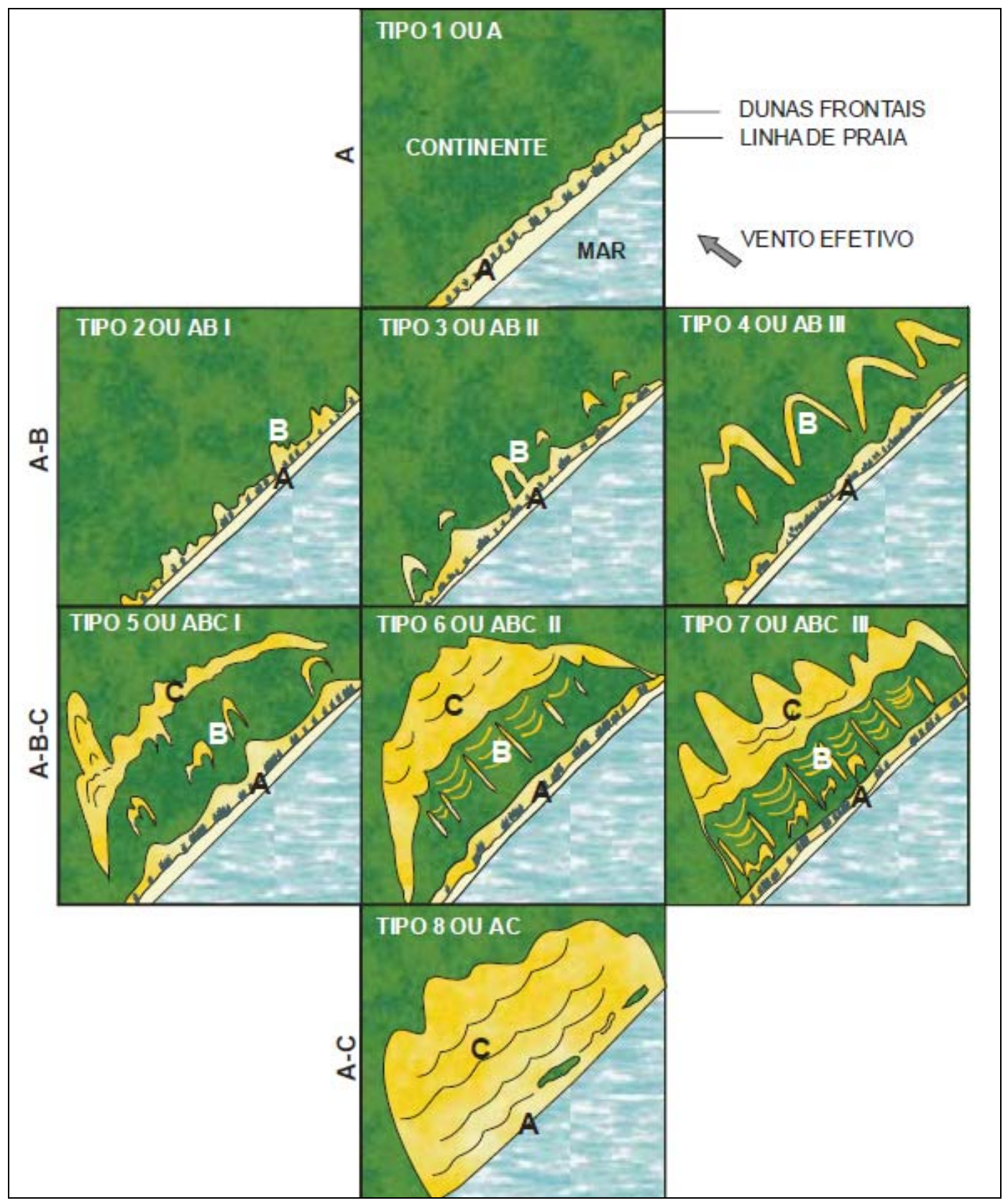

Figura 6.30. Tipos de sistemas eólicos costeiros do Brasil, sob condição de vento efetivo transversal à linha de costa. A, B e C são associações de elementos morfológicos: praia-duna, planície deflacionária e campo de dunas livres, respectivamente, conforme Figura 2.3. Do tipo 1 ao 8, tem-se crescimento no saldo sedimentar eólico relativo (aporte eólico / espaço de acumulação). Extraído de Giannini et al. (2014).

\subsubsection{Distribuição dos eolianitos no tempo}

Cerca de $80 \%$ das datações de eolianitos realizadas em grãos de quartzo, pelo método da luminescência (LOE), e em bioclastos ou no cimento calcítico, por ${ }^{14} \mathrm{C} \mathrm{AMS}$, concentra-se no intervalo entre 800 e 3200 anos (Figura 6.31). Estas idades são compatíveis com os resultados de ${ }^{14} \mathrm{C}$ encontrados por Castro \& Ramos (2006) nos eolianitos do segmento de Macau a Jericoaquara, entre $1780 \pm 80$ e $1320 \pm 50$ anos A.P., e correlacionáveis com datações realizadas em paleodunas terrígenas denominadas D2 e D3 
por Claudino Sales (2002) no Ceará, e em depósitos eólicos "recentes" (isto é, formados após a transgressão holocênica) por Guedes (2012) no Maranhão.

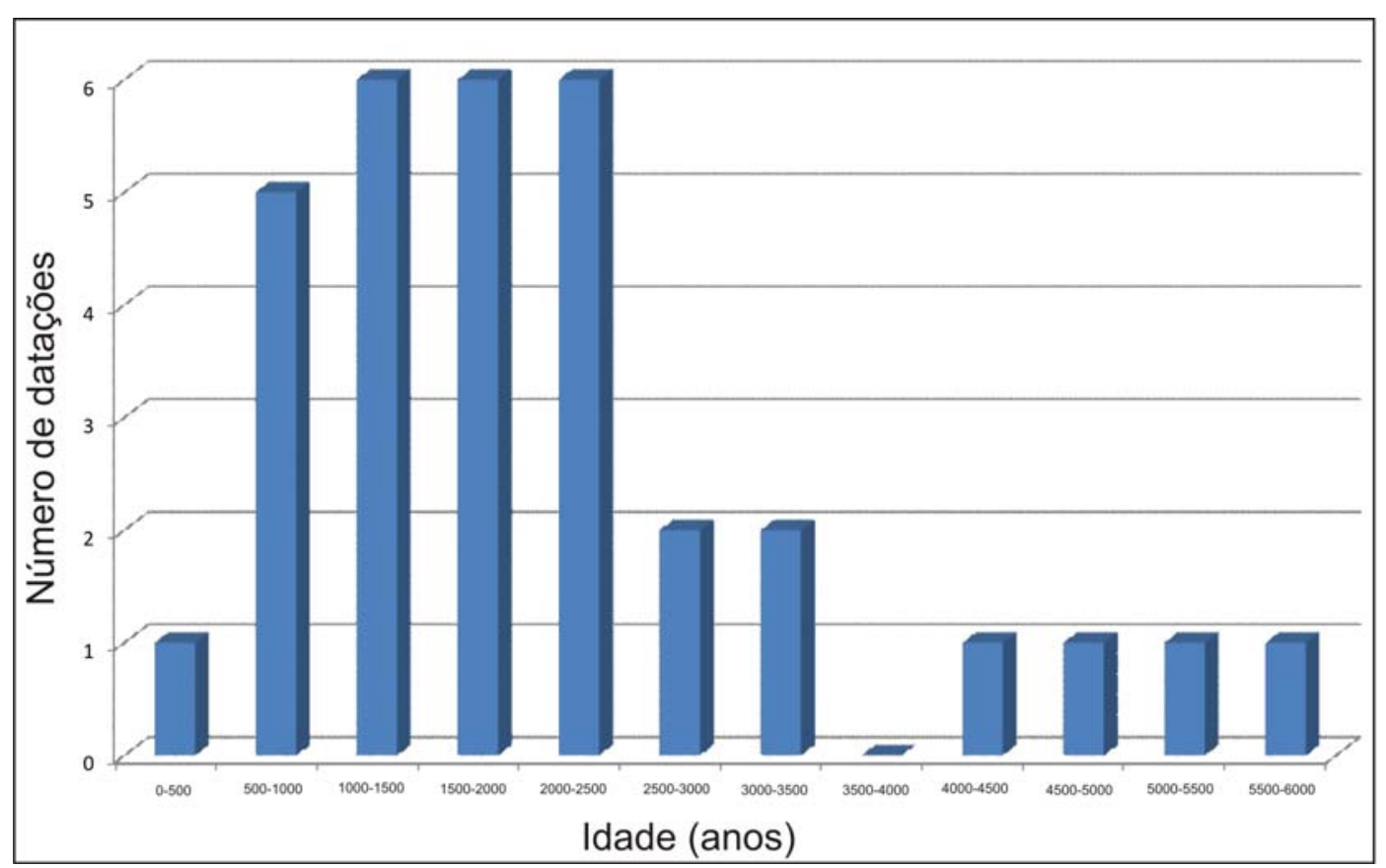

Figura 6.31. Histograma das idades obtidas em eolianitos, em intervalos de classe de 500 anos. Para a construção do gráfico, foram consideradas as idades medianas

$\mathrm{Na}$ escala dos glaciais e interglaciais quaternários, ligados ao ciclo orbital de excentricidade de Milankovitch, estas idades apontam para a formação dos eolianitos em contexto de NRM alto, situação também muito frequente dentre os sistemas eólicos costeiros terrígenos do Brasil. A formação de sistemas eólicos nessa situação é favorecida pela grande quantidade de sedimentos em circulação no prisma costeiro ao final da transgressão (Lees 2006, Giannini et al. 2007), pela manutenção do NRM e, por extensão, da linha de costa, com maior chance de acúmulo de areia eólica numa mesma faixa costeira (Giannini et al. 2007) e, no contexto do NRM alto atual em particular, pela menor chance de erosão superimposta (Mendes et al. 2015). No caso da sedimentação eólica carbonática, porém, os contextos de NRM alto são ainda mais favoráveis, já que, por implicarem elevação de nível de base, significam redução ou mesmo represamento do aporte terrígeno a montante, com favorecimento da criação de plataformas carbonáticas. De fato, Brooke (2001) demonstra que a distribuição global das idades dos eolianitos quaternários evidencia forte controle pelas variações de NRM ligadas à ciclicidade entre glaciais e interglaciais. E que várias das ocorrências clássicas, como Bermudas, Bahamas, Coorong (Austrália) e Mediterrâneo ocidental têm sua formação atribuída a contextos de NRM alto. As exceções incluiriam eolianitos formados no UMG, por exemplo no sudoeste da Austrália, onde os períodos glaciais teriam sido mais secos e ventosos (Brooke 2001).

Em escala de tempo mais reduzida, do Holoceno, o período preferencial de formação dos eolianitos estudados, de 3200 a 800 anos, incide em época de NRM mais alto que o atual na região (até $3 \mathrm{~m}$ ) (Caldas et al. 2006, Vasconcelos et al. 2014). Esta 
conclusão contraria a interpretação de Maia et al. (1997), segundo o qual a transferência dos bioclastos da plataforma continental adjacente para a zona costeira teria que ter ocorrido em condições transgressivas, durante período de nível do mar mais baixo. Contraria também o modelo de Carvalho et al. (2008) para a costa de Flecheiras, em Trairi, em que se interpreta que a maioria dos eolianitos corresponde a uma fase de nível de mar baixo, passando, com a subida de NRM e a queda do aporte sedimentar, de dunas compostas para grandes dunas parabólicas. Aparentemente, as interpretações de Maia et al. (1997) e Carvalho et al. (2008) partem da premissa de que a fonte imediata dos eolianitos é a plataforma continental hoje submersa e não a praia, o que, no entanto, não encontra reforço nos dados sedimentológicos (e.g. teor de carbonato) aqui obtidos (Artigo 2). Por outro lado, não se descarta a possibilidade de que a formação da superfície de ravinamento, durante a transgressão holocênica, tenha ajudado a gerar e a carrear bioclastos carbonáticos das partes mais profundas para as mais rasas da plataforma.

Embora não seja impeditivo para a geração de campos de dunas livres, o contexto de NRM em declínio dos últimos 5 a 6 mil anos tampouco é o mais favorável, já que parte do estoque de areia costeira passa a ser gasta com a progradação subaquosa, o que reduz a sobra de sedimentos disponíveis ao vento (Giannini 2007, Giannini et al. 2007, 2011, 2014). Nesta escala temporal de análise, porém, fatores ligados ao clima local, como precipitação ou intensidade dos ventos, tornam-se tão ou mais importantes que o comportamento do NRM e da linha de costa para explicar o desencadeamento ou fixação das dunas costeiras (Guedes et al. 2011, Mendes \& Giannini 2015, Mendes et al. 2015). Se o desencadeamento aqui pode ter sido a própria estabilização do NRM no meio do Holoceno, após um longo período de transgressão pós-glacial, a estabilização pode ter-se dado tanto pela própria exaustão do aporte, em vista da regressão e/ou do simples afastamento entre campos de dunas e área fonte (bem exemplificada no setor centro), quanto por fatores climáticos. Estabelecem-se assim duas hipóteses para a estabilização dos eolianitos: a de estabilização autogênica, por distanciamento da fonte via migração do campo de dunas e/ou via progradação; e a de estabilização alogênica, por umidificação do clima e/ou enfraquecimento dos ventos, o que somado à composição carbonática dos clastos, gerou a cimentação carbonática precoce, numa escala de séculos.

Dois rastros lineares residuais pobres em carbonato e com laminação cruzada "pin stripe", um inconsolidado, próximo a Luís Correia (EPI02), e outro moderadamente coeso, indicando início de cimentação carbonática, da área de Macapá (EPI13R), foram datados por LOE em 365 e 170 anos, respectivamente. Estas idades sugerem que embora a cimentação precoce continue ocorrendo localmente, dentro dos últimos quatro séculos, este tempo não é suficiente para formar depósitos coesos, bem cimentados, nos moldes do que foi aqui definido como eolianito.

\subsubsection{Significado das fácies deposicionais e de sua distribuição no tempo}

Se na escala global a regional, a distribuição espacial de eolianitos depende fortemente da presença de plataforma carbonática e de condições climáticas e de regimes de ventos e de ondas favoráveis, em escala de mais detalhe, dentro de um campo de dunas, 
por exemplo, esta distribuição é controlada pela idade do depósito (tempo hábil para a cimentação calcítica) e pela concentração aerodinâmica de bioclastos carbonáticos, o que pode ter relações com a forma, o tamanho e a densidade destes clastos, mas também com o processo deposicional, materializado nas fácies.

Os eolianitos da costa do Piauí e Ceará apresentam quatro fácies deposicionais principais, que têm a ver com o ângulo de mergulho das estratificações, alto ou baixo, e com a presença, abundante ou escassa, de rizoconcreções. No padrão dominante de sucessão de fácies, as com estratificações cruzadas de mergulho alto encontram-se subjacentes às de mergulho baixo, as quais eventualmente apresentam o mesmo caimento da topografia do topo do cordão de eolianito. As rizoconcreções observam-se tanto nas fácies de ângulo de mergulho alto quanto nas de ângulo baixo, só que mais abundantes nestas últimas. O padrão de dispersão das estratificações cruzadas é predominantemente bimodal, tendo a direção do vento efetivo e do alongamento das cristas de eolianitos como bissetriz entre as duas modas. A morfologia alongada dos cordões de eolianito, sua associação espacial com rastros lineares ativos, a elevada concentração de grossos (teor de areia grossa mais muito grossa de $20 \%$ até $50 \%$ ) e o padrão divergente de distribuição de azimutes de mergulho permitem associá-los com antigos rastros lineares, estabilizados e cimentados. Desse modo, as fácies de ângulo alto representariam o avanço da face externa, de caráter mais deposicional, dos rastros lineares, enquanto as fácies de ângulo baixo representariam o aplainamento de sua crista, já na fase de abandono da sedimentação e de progressiva colonização vegetal. A interpretação das fácies presentes nos eolianitos resume-se no Quadro 7.

Quadro 7. Interpretação das fácies deposicionais de eolianitos

\begin{tabular}{|c|c|c|}
\hline $\begin{array}{l}\text { Código de } \\
\text { fácies }\end{array}$ & $\begin{array}{c}\text { Associação } \\
\text { de elementos } \\
\text { morfológicos }\end{array}$ & Processos e elemento morfológico \\
\hline $\mathrm{Ac}_{\mathrm{a}}$ & $\begin{array}{c}\text { Planície } \\
\text { deflacionária }\end{array}$ & $\begin{array}{c}\text { Queda e fluxo de grãosno flanco externo de rastro linear } \\
\text { residual }\end{array}$ \\
\hline $\mathbf{A c}_{\mathrm{b}}$ & $\begin{array}{c}\text { Planície } \\
\text { deflacionária }\end{array}$ & $\begin{array}{c}\text { Aprisionamento de grãos alternado com deflaçãono topo } \\
\text { aplainado de rastro linear residual }\end{array}$ \\
\hline $\mathbf{A c}_{\mathbf{a}} \mathbf{r}_{\mathrm{e}}$ & $\begin{array}{c}\text { Planície } \\
\text { deflacionária }\end{array}$ & $\begin{array}{c}\text { Estabilização por vegetação de flanco externo de rastro linear } \\
\text { residual }\end{array}$ \\
\hline $\mathbf{A c}_{\mathbf{b}} \mathbf{r}_{\mathbf{a}}$ & $\begin{array}{c}\text { Planície } \\
\text { deflacionária }\end{array}$ & $\begin{array}{c}\text { Estabilização por vegetação de topo aplainado de rastro } \\
\text { linearresidual }\end{array}$ \\
\hline $\mathrm{Ac}_{\mathbf{f}} \mathbf{r}_{\mathbf{a}}$ & $\begin{array}{l}\text { Praia-duna } \\
\text { (lençol de } \\
\text { areia) }\end{array}$ & $\begin{array}{l}\text { Avanço deblow-outs ou dunas parabólicaspor sobre antigas } \\
\text { falésias costeiras, seguido de estabilização por vegetação }\end{array}$ \\
\hline
\end{tabular}

Nos depósitos associados aos eolianitos, algumas das fácies reconhecidas só ocorrem em pontos próximos a eles, podendo em tese incluir suas variações laterais na mesma paleogeografia, caso lhe sejam contemporâneos. Esse é o caso das fácies Ap, Amg, Am e Rg. No entanto, a datação LOE da fácies Ap indica idade muito mais antiga (cerca de 13ka) que a dos eolianitos, e a fácies Am, pelo baixo grau de cimentação, deve 
corresponder a depósito eólico mais recente. Assim, apenas Amg e Rg podem ser inseridas no mesmo cenário deposicional dos eolianitos estudados.

A fácies Amg ocorre em contato discordante sobre Ap e com idades ${ }^{14} \mathrm{C}$ entre 1724 a 1398 e 2354 a 2502 anos cal A.P. Corresponde ao capeamento arenoso escuro de até 50 cm de espessura, com conchas de gastrópodes, descrito por Lehugeur (1995) e interpretado por este autor como registro da fixação de paleodunas. De fato, as características desta fácies, tais como escurecimento gradual para o topo, atribuído à presença de matéria orgânica coloidal, e a formação de uma crosta cimentada por carbonato de cálcio, coberta pelas areias inconsolidadas da fácies Am (Figura 6.22), levam à sua interpretação como solo soterrado (paleossolo). Esta interpretação é reforçada pela presença das carapaças inteiras e de diferentes tamanhos de Pomacea sp., gastrópode cujo hábitat corresponde a fundos sedimentares sob lâmina de água muito rasa (centimétrica) e que foi observado em campo, em grandes quantidades (dezenas por $\mathrm{m}^{2}$ ), nas porções inundadas da planície de deflação ou das interdunas dos sistemas eólicos costeiros da região vizinha a oeste (e.g. Tutoia, MA). Na estação seca, com o abaixamento do freático, os moluscos morrem e suas carapaças são soterradas ou incorporadas em meio a pavimentos de deflação (Figura 6.32). Esta é a origem interpretada, portanto, para a fácies Amg, que pode ter-se desenvolvido nas zonas baixas e úmidas adjacentes aos rastros lineares residuais que geraram os eolianitos. Como esta fácies tem expressão regional, sempre ocorrendo sob depósitos da planície de deflação recente, não pode ser descartada a hipótese de que ela represente um hiato, ligado a mudança climática, relacionado com a estabilização dos eolianitos.

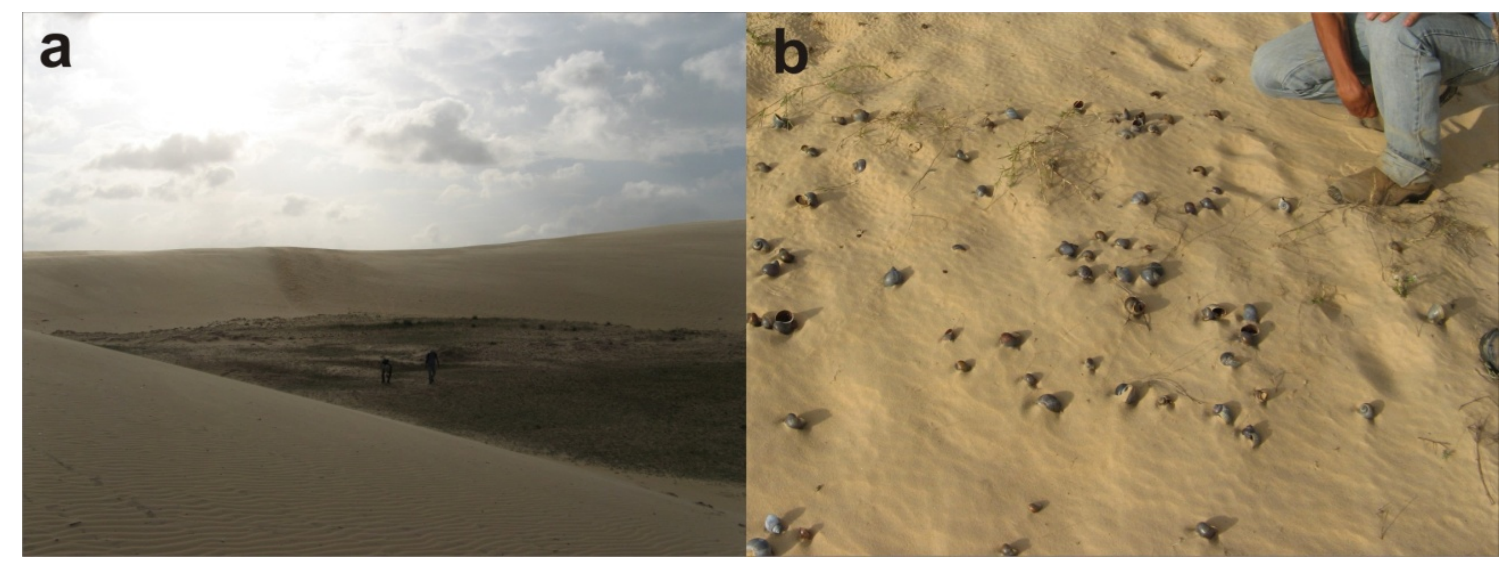

Figura 6.32. Ocorrência de Pomacea sp. no campo de dunas costeiras de Tutoia, MA. A. a. contexto de ocorrência: interdunas úmida e vegetada. b. concentração de carapaças de gastrópodes mortos. Fotos obtidas por Carlos C.F. Guedes, na estação seca de 2010.

A fácies Rg corresponde a acúmulos monticulares alongados de carapaças inteiras de Gastrocopta, gastrópode pulmonado terrestre que habita preferencialmente solos endurecidos ou afloramentos calcários em condições xéricas ou mésicas secas (Nekola 1999, Nekola \& Coles 2001). Essa condição é oferecida, na região, principalmente pelos próprios depósitos de eolianitos, e a fácies pode, portanto, ser considerada indicadora da preexistência destes depósitos.

As demais fácies dos depósitos associados apresentam, assim como Ap, relações estratigráficas de campo e/ou idades absolutas que permitem considerá-las como substratos 
do eolianito. Na ordem de idade decrescente, estas fácies são Rm (Formação Barreiras), RAr a ("pós-Barreiras"), Ap, Apb (beach-rock) e Apr $\mathbf{e}$.O "pós-Barreiras" caracteriza-se por intercalações de areias bem selecionadas, muito similares às das dunas eólicas sobrejacentes, com depósitos areno-conglomeráticos subaquosos cuja frequência e espessura decrescem para cima. Este tipo de situação geológica, interdigitação entre fácies conglomeráticas subaquosas e arenáceas supostamente eólicas nos primeiros metros de depósitos sedimentares logo acima do contato com a Formação Barreiras, verifica-se em campo em toda a região costeira entre Zumbi, no Rio Grande do Norte, e os Lençóis Maranhenses. Desse modo, o "pós-Barreiras" pode ser considerado o primeiro registro de influência do vento na sedimentação quaternária regional. A fácies Ap corresponde provavelmente ou a terraços marinhos do Pleistoceno superior correlatos ao NRM alto de $120 \mathrm{ka}$ ou a depósitos eólicos sobre estes terraços, modificados, os quais teriam neste caso sido modificados por deflação sob clima possivelmente mais seco. A idade LOE encontrada nesta fácies $(13,3 \pm 1,0 \mathrm{ka})$ aponta para esta segunda hipótese e corresponde a fase de NRM baixo, portanto com linha de costa distante. A este respeito, é importante lembrar que Guedes et al. (2011, 2013) e Guedes (2012) encontraram, na região dos Lençóis Maranhenses, vizinha a oeste, evidências de uma marcante fase de estabilização de dunas eólicas pela vegetação, no período úmido entre 19 e 14 ka, interpretado como correlata ao evento H1. A idade registrada em Ap sobrepõe-se com o limite superior do intervalo encontrado por aqueles autores no Maranhão e pode representar o mesmo evento regional de estabilização de depósitos eólicos.

A fácies Apb (beach-rock) apresenta séries cuneiformes de estratificações planoparalelas com mergulho baixo para o mar, o que permite sua interpretação como fácies de espraiamento. Ela ocorre de 2 a $4 \mathrm{~m}$ acima da zona média de espraiamento ativo, o que significa que, muito provavelmente, formou-se cerca de 5400 anos cal A.P. (datação ${ }^{14} \mathrm{C}$ de bioclastos), sob NRM mais elevado que o atual. Este dado reforça a interpretação, feita previamente com base em Angulo et al. (2006), Caldas et al. (2006), Vasconcelos et al. (2014), de que o NRM no Ceará encontra-se em declínio desde essa época.

A fácies $\mathbf{A p r}_{\mathbf{e}}$ ocorre discordantemente sobre $\mathbf{R m}$ ou em contato transicional sobre Apb, diferenciando-se desta última pela granulação arenosa mais fina e pelo escasseamento e redução de tamanho dos bioclastos. Por esta última característica, ela é aqui interpretada como depósito de pé de duna frontal ou de lençol de areia eólica, junto ao alcance médio superior da zona de espraiamento. Esta interpretação é reforçada pelo fato de nas porções mais elevadas do afloramento, a mais de $4 \mathrm{~m}$ de desnível em relação à praia atual, ser esta a fácies encontrada entre o embasamento neógeno (Formação Barreiras) e os eolianitos, sem a presença de fácies Apb espessa abaixo, mas com recorrências centimétricas de arenitos ricos em bioclastos análogos ao da fácies Apb. Um resumo das interpretações das fácies associadas encontra-se no Quadro 8. 
Quadro 8. Interpretação das fácies deposicionais associadas aos eolianitos, ordenadas da mais antiga para a mais nova.

\begin{tabular}{|c|c|c|}
\hline $\begin{array}{l}\text { Código de } \\
\text { fácies } \\
\text { (unidade } \\
\text { estratigráfica) }\end{array}$ & $\begin{array}{l}\text { Associação de } \\
\text { elementos } \\
\text { morfológicos }\end{array}$ & Processos e elementos morfológicos \\
\hline $\begin{array}{c}\text { Rm } \\
\text { (Formação } \\
\text { Barreiras) }\end{array}$ & $\begin{array}{l}\text { Leques aluviais, e } \\
\text { rios entrelaçados } \\
\text { associados, junto } \\
\text { à costa }\end{array}$ & $\begin{array}{l}\text { Fluxosde detritos coesivos, enxurradasdesconfinadas e } \\
\text { migração de barras transversais e longitudinais (braids), } \\
\text { com retrabalhamento eventual por agentes costeiros }\end{array}$ \\
\hline $\begin{array}{l}\text { RAr }_{a} \\
\text { (“pós- } \\
\text { Barreiras”) }\end{array}$ & $\begin{array}{l}\text { Rampas de } \\
\text { colúvio e/ou } \\
\text { rampas eólicas } \\
\text { costeiras } \\
\text { ancoradas em } \\
\text { falésias da Fm. } \\
\text { Barreiras }\end{array}$ & $\begin{array}{c}\text { Fluxos de detritos coesivos e } \\
\text { enxurradasdesconfinadasalternados comepisódios de } \\
\text { retrabalhamento ou deposição eólica em lençolcada vez } \\
\text { mais frequentes }\end{array}$ \\
\hline Ap & $\begin{array}{c}\text { Planície } \\
\text { deflacionária } \\
\text { (sobre paleodunas } \\
\text { costeiras?) }\end{array}$ & $\begin{array}{l}\text { Retrabalhamento de areias preexistentes em áreas de } \\
\text { deflação planas }\end{array}$ \\
\hline $\begin{array}{c}\text { Apb } \\
\text { (beach-rock) }\end{array}$ & Praia & $\begin{array}{l}\text { Deposição de areia com rudáceos esparsos em leito plano } \\
\text { deregime de fluxo superior, na zona de espraiamento }\end{array}$ \\
\hline $\begin{array}{c}\text { Apr }_{\mathrm{e}} \\
\text { (transição } \\
\text { beach-rock / } \\
\text { eolianito) }\end{array}$ & $\begin{array}{c}\text { Praia-duna } \\
\text { (lençol de areia) }\end{array}$ & $\begin{array}{l}\text { Deposição de areia com rudáceos esparsos em leito plano } \\
\text { de regime de fluxo superior, na zona de espraiamento ou na } \\
\text { berma, alternada com deposição eólica em lençol }\end{array}$ \\
\hline Amg & $\begin{array}{c}\text { Praia-duna (lençol } \\
\text { de areia) ou } \\
\text { planície } \\
\text { deflacionária } \\
\text { costeira }\end{array}$ & $\begin{array}{c}\text { Aprisionamento de areia eólica em retrocordões e/ou } \\
\text { porções úmidas da planície ou lençol, habitadas por } \\
\text { gastrópodes aquáticos continentais, e formação de solo } \\
\text { carbonático }\end{array}$ \\
\hline Rg & $\begin{array}{c}\text { Planície } \\
\text { deflacionária } \\
\text { costeira }\end{array}$ & $\begin{array}{l}\text { Exposição por deflação e colonização por gastrópodes de } \\
\text { crostas carbonáticas, inclusive eolianitos preexistentes }\end{array}$ \\
\hline Am & $\begin{array}{l}\text { Planície } \\
\text { deflacionária } \\
\text { costeira }\end{array}$ & $\begin{array}{c}\text { Aprisionamento de areia eólica em retrocordões e porções } \\
\text { vegetadas da planície }\end{array}$ \\
\hline
\end{tabular}

A análise das idades em função da distância à praia revela que os eolianitos mais próximos à linha de costa são mais antigos que os mais distantes; este padrão de variação espacial de idade é compatível com o esperado em rastros lineares residuais, os quais são sucessivamente deixados para trás e estabilizados à medida que o campo de dunas migra, o que reforça a hipótese de associação dos eolianitos com aquele tipo de feição.

$\mathrm{O}$ exame da variação das idades em função da distância de W para $\mathrm{E}$ (e de N para S) indica que as idades mais antigas são encontradas no setor norte, seguidas dos setores centro e sul. No setor norte, as idades claramente aumentam de N para S (do Piauí para o extremo oeste do Ceará). Esta tendência acompanha a redução gradual do ângulo entre vento e costa, de até $60^{\circ}$, no Piauí, para $30^{\circ}$, na região de Camocim, no Ceará. Assim, uma hipótese para explicar este resultado é a de que onde o ângulo vento-costa é menor, o distanciamento dos eolianitos em relação à costa também diminui, os eolianitos, portanto, 
empilham-se mais e isto permite a preservação, na base da sucessão, de depósitos mais antigos. Esta hipótese é reforçada pelo aumento da altura dos afloramentos do Piauí para o Ceará, ao longo do setor norte. Reforça-se também pelo fato de que a maioria dos eolianitos mais jovens encontrados está no Piauí (onde o ângulo vento-costa é o mais elevado), seguidos pelos dos setores sul (ângulo vento-costa de até $45^{\circ}$ ) e centro (ângulo de $\left.40^{\circ}\right)$.

Finalmente, as idades LOE de dois rastros lineares terrígenos abandonados da área de Macapá (Luís Correia), um não cimentado (EPI02, 365 anos) e outro com leve cimentação carbonática (EPI13R, 170 anos), sugerem que a formação dos eolianitos não mais se têm completado pelo menos nos últimos quatro séculos.

\subsection{Conclusões}

Com base nos resultados obtidos e discutidos neste artigo, pode-se listar as seguintes conclusões:

- O litoral compreendido entre Luís Correia (PI) e Paracuru (CE) encontra-se na parte sul da ZCIT, faixa de umidade para onde os ventos alísios de NE e SE convergem, com domínio de alísios de NE a norte, passando gradualmente a alísios de SE, a sul. Geram-se assim as três direções de vento efetivo nítidas na região, de NE, de E e de ESE, o que levou a dividir a área de estudo em três setores: norte, centro e sul, respectivamente.

- A variação do ângulo entre a direção do vento efetivo e a linha de costa ao longo do litoral estudado determina a extensão das feições deflacionárias e deposicionais; assim, se esse ângulo é de mais de $45^{\circ}$, situação dominante na porção piauíense do setor norte, as feições deflacionárias são mais bem desenvolvidas que as deposicionais; mas se o ângulo é menor, situação dominante no Ceará, as feições deposicionais se tornam maiores que as deflacionárias.

- Este ângulo influi também na relação entre taxa de empilhamento vertical versus taxa de migração horizontal. Assim, os campos de dunas do Piauí são mais extensos, mas seus depósitos de eolianito mais delgados que os do Ceará.

- Na classificação da área de estudo segundo os tipos de sistemas eólicos previamente reconhecidos na costa brasileira, os setores norte e sul têm predomínio do tipo 6, com as três associações de elementos morfológicos (praia-duna, planície de deflação e campo de dunas livres), enquanto o setor centro é dominado pelo tipo 4, em que falta a associação campo de dunas, e pelo tipo 5, onde esta associação restringe-se a dunas parabólicas coalescidas. Esta distribuição geográfica dos tipos de sistemas indica maior saldo e saturação eólica nos setores norte e sul de que no setor centro.

- A menor saturação eólica do setor centro está ligada à rápida progradação de fácies subaquosas neste setor, o que diminui a disponibilidade de sedimentos disponíveis ao vento. 
- A formação de eolianitos está ligada à composição da plataforma continental adjacente e a zona principal de sua ocorrência na costa nordeste do Brasil coincide com o trecho em que a plataforma carbonática se encontra mais rasa e próxima da costa.

- O clima seco e quente favorece a formação de eolianitos por vários motivos: por propiciar a construção da plataforma continental interna adjacente, onde cresce a comunidade bentônica (algas vermelhas e foraminíferos) geradora de carbonatos; por possuir correlação com a força dos ventos, o que aumenta a erosão dos carbonatos submersos pelas ondulações, seu transporte até a costa e seu retrabalhamento no sistema eólico; e por elevar a taxa de precipitação química por evaporação nos depósitos eólicos, o que induz a cimentação precoce e a consolidação dos eolianitos.

- Fatores ligados ao clima local a regional como variações de precipitação ou intensidade dos ventos podem também explicar a fixação de dunas costeiras; assim, é possível que a estabilização de eolianitos seja alogênica, por umidificação do clima e/ou enfraquecimento dos ventos.

- No entanto, a fixação por umidade e vegetação pode estar ligada a aumento do nível freático em relação à superfície deposicional. $\mathrm{O}$ nível freático é relativamente mais alto na planície de deflação e sua altura relativa depende portanto da porção do sistema e da fácies. Assim, a fixação das dunas carbonáticas pode também ser autogênica, pela expansão da zona de deflação que se dá via migração de campo de dunas e/ou via progradação.

- A morfologia alongada das cristas dos eolianitos, paralela ao vento efetivo atual, o padrão bimodal de suas estratificações cruzadas, o fato de o alongamento das cristas coincidir com a bissetriz entre as duas modas, sua associação espacial preferencial comrastros lineares ativos e a elevada concentração de grãos grossos, típicos de deposição residual, indicam que eles são formados na zona deflacionária, onde correspondem a antigos rastros lineares, estabilizados e cimentados.

- A maioria (80\%) das idades de eolianitos concentra-se no intervalo de 800 e 3200 anos, apontando para sua formação em contexto de NRM alto (3 $\mathrm{m}$ acima do atual) e relativamente estável. Embora este seja um dos contextos favoráveis à formação de dunas eólicas em geral, sendo comuns paleodunas terrígenas com este intervalo na costa brasileira, a favorabilidade deste contexto é aumentada, no caso dos depósitos eólicos carbonáticos, já que a elevação de nível de base significa redução ou mesmo represamento do aporte terrígeno a montante, com favorecimento da criação de plataformas carbonáticas.

- Quanto à variação espacial, as datações realizadas nos eolianitos revelaram dois padrões: primeiro, tornam-se mais novos à medida que se afastam da praia, o que é compatível com o esperado em rastros lineares residuais; segundo, as idades mais antigas (superiores a 5000 anos) concentram-se na parte cearense do setor norte (área de Camocim), que é região de maior paralelismo entre vento efetivo e linha de costa e, portanto, de maior empilhamento e preservação de gerações de depósitos. 
- Entre as litologias associadas aos eolianitos, só as fácies Amg e Rg apresentam idades próximas a eles, pelo que podem ser inseridas no mesmo cenário deposicional. A fácies Amg, com representatividade regional e idades entre 2500 e 1390 anos, corresponde a paleossolo, desenvolvido nas zonas baixas e úmidas da planície deflacionária adjacentes aos rastros lineares residuais que geraram os eolianitos. A fácies Rg, com idade de 2100 anos, apresenta gastrópodes terrestres que habitam preferencialmente solos endurecidos ou afloramentos calcários, pressupondo a existência prévia de eolianitos. A idade da fácies, coincidente com a moda das idades ${ }^{14} \mathrm{C}$ e LOE de eolianitos, não favorece a hipótese de existência de um hiato deposicional de expressão regional.

- As fácies Apb (beach-rocks), com estratificações plano-paralelas de mergulho baixo, interpretadas como de espraiamento, apresenta idade de 5400 anos e representa paleonível de 2 a $4 \mathrm{~m}$ acima do atual, o que reforça interpretações previas de que o NRM no Ceará encontra-se em declínio desde essa época.

- As idades LOE de dois rastros lineares terrígenos abandonados da área de Macapá (Luís Correia), um não cimentado (EPI02, 365 anos) e outro com leve cimentação carbonática (EPI13R, 170 anos), sugerem que a formação dos eolianitos não mais se tem completado pelo menos nos últimos quatro séculos.

\section{Artigo 2 - Sedimentologia e petrografía dos eolianitos holocênicos da costa do Piauí e Ceará}

\subsection{Resultados}

\subsubsection{Granulometria}

A granulometria foi feita em um total de 82 amostras, das quais 52 correspondem a eolianitos, 21 à praia-duna ativa e nove a outras fácies associadas. Nas análises realizadas nas praias e dunas adjacentes aos eolianitos a barlavento, observou-se que a seleção é moderada a pobre (desvio padrão variável de 0,5 a 1,2 ), com tamanho médio de grãos de quartzo e bioclastos carbonáticos desde areia muito grossa até areia fina.

As 52 amostras de eolianito foram analisadas quanto a diâmetro médio, desvio padrão e assimetria, segundo três setores geográficos baseados no Artigo 1 (Figuras 7.1 a 7.3): setor norte-Piauí; setor norte-Ceará; e setor centro-sul. Destas 52 amostras de eolianitos, 47 foram selecionadas também para a análise da relação da granulometria com as fácies (Figuras 7.4 a 7.6), por pertencerem às três fácies deposicionais mais representativas de acordo com o Artigo 1: arenito com estratificação cruzada de ângulo alto $\left(\mathbf{A} \mathbf{c}_{\mathbf{a}}\right)$, arenito com estratificação cruzada de ângulo baixo $\left(\mathbf{A} \mathbf{c}_{\mathbf{b}}\right)$ e arenito com estratificação cruzada de ângulo baixo, rico em rizoconcreções $\left(\mathbf{A} \mathbf{c}_{\mathbf{b}} \mathbf{r}_{\mathbf{a}}\right)$. 
As 52 amostras de eolianitos analisadas segundo os setores geográficos apresentam, em conjunto, um valor médio de diâmetro médio de 1,7 (areia média), com mínimo de 0,7 (areia grossa) e máximo de 2,6 (areia fina) (Figura 7.1). O setor norte-Piauí apresenta mediana $(1,8$ ) e intervalos interquartis (1,6 a 2,3 ) do diâmetro médio mais finos que o do setor norte-Ceará (1,6 e 1,1 a 1,8 , respectivamente). Este, por sua vez, possui mediana e intervalo interquartis mais finos que os encontrados no setor centro-sul $(1,1$ e 0,7 a 1,6 , respectivamente). Configura-se assim uma tendência para engrossamento do tamanho de grão ao sul.

O desvio padrão da distribuição granulométrica varia entre cerca de 0,4 e 1,3

(Figura 7.2). O intervalo interquartis do setor centro-sul é mais estreito que os dos dois setores ao norte (amplitude de menos de 0,2 contra aproximadamente 0,5 ), porém inteiramente neles contido. Isto sugere maior homogeneidade interamostral no centro-sul, porém sem diferenças significativas de grau de seleção granulométrica. Por outro lado, tomando a mediana como referência, o setor norte-Piauí possui o desvio padrão granulométrico mais baixo e, portanto, o melhor grau de seleção.

A assimetria da distribuição granulométrica varia de $-1,1$ a 0,9 (Figura 7.3). Os intervalos interquartis encontram-se entre $-0,5$ e 0,6 , com tendência gradual de aumento dos valores de norte para sul. Assim, enquanto o intervalos interquartis do setor norte-Piauí apresenta assimetria negativa a nula, o setor centro-sul apresenta assimetria nulas a positivas, com o setor norte-Ceará exibindo valores intermediários.

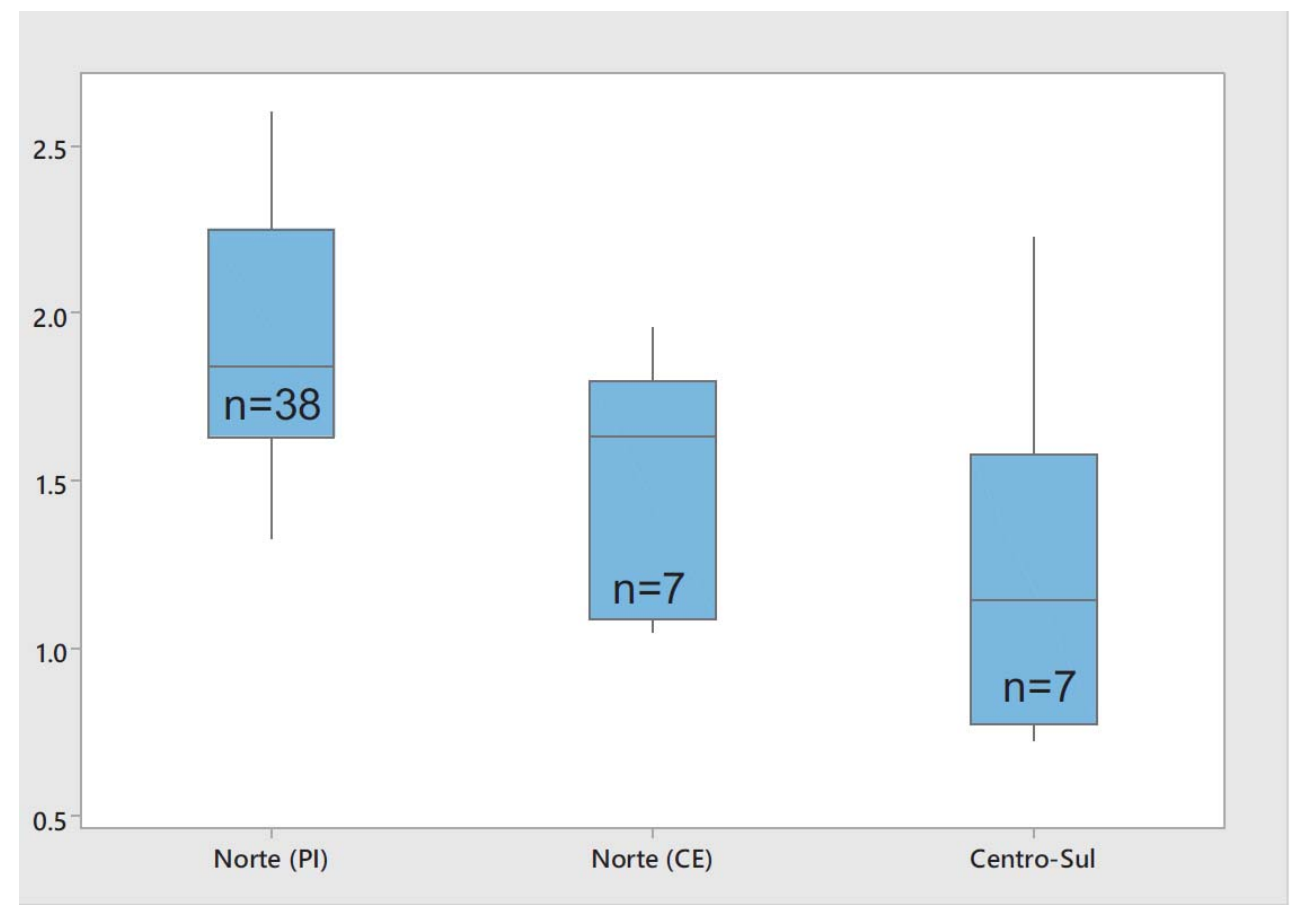

Figura 7.1. Diagrama em caixa para variação do diâmetro médio da distribuição granulométrica em phi dos eolianitos, segundo três setores geográficos de norte para sul. 


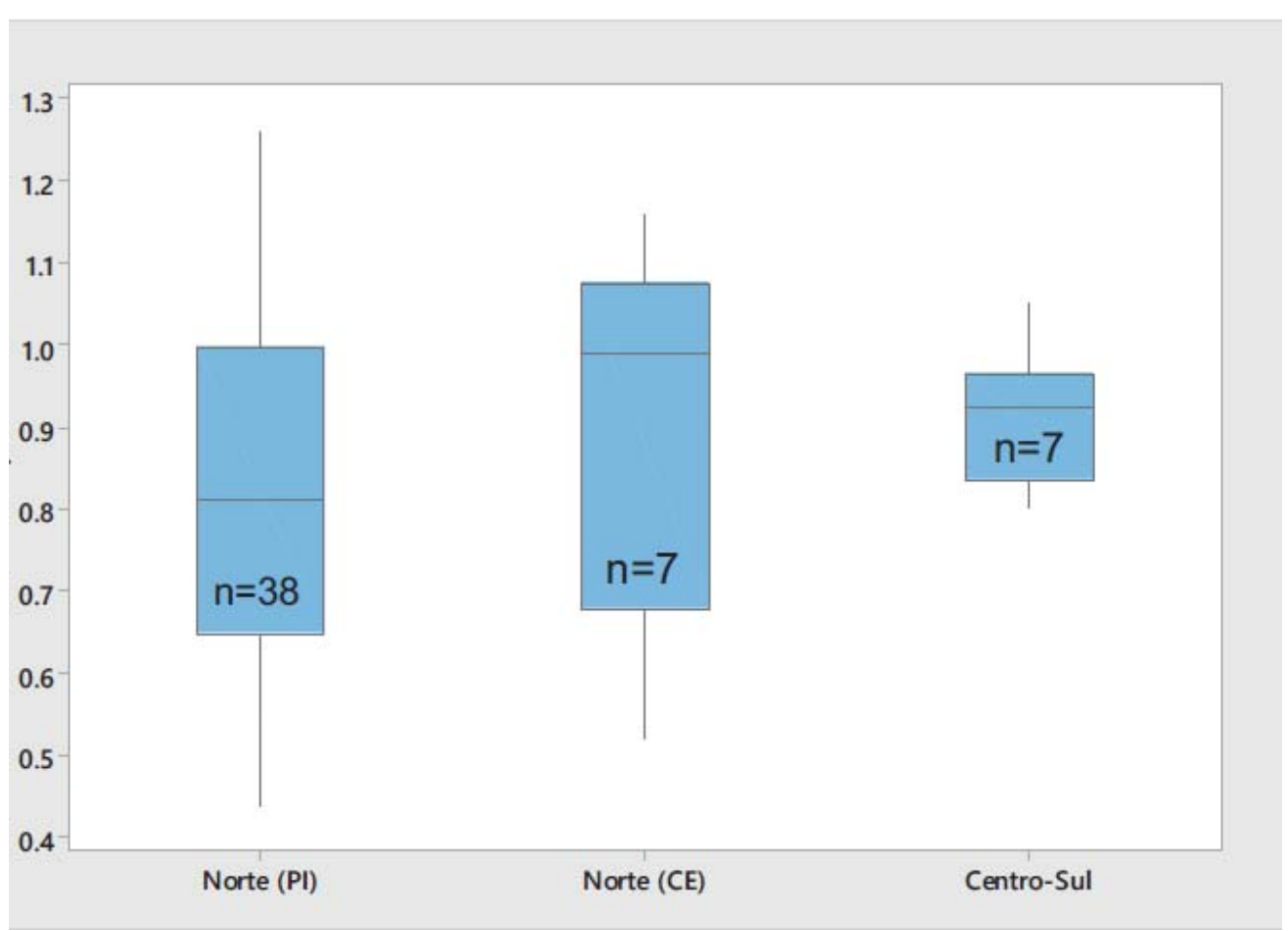

Figura 7.2. Diagrama em caixa para variação do desvio padrão da distribuição granulométrica em phi dos eolianitos, segundo três setores geográficos de norte para sul.

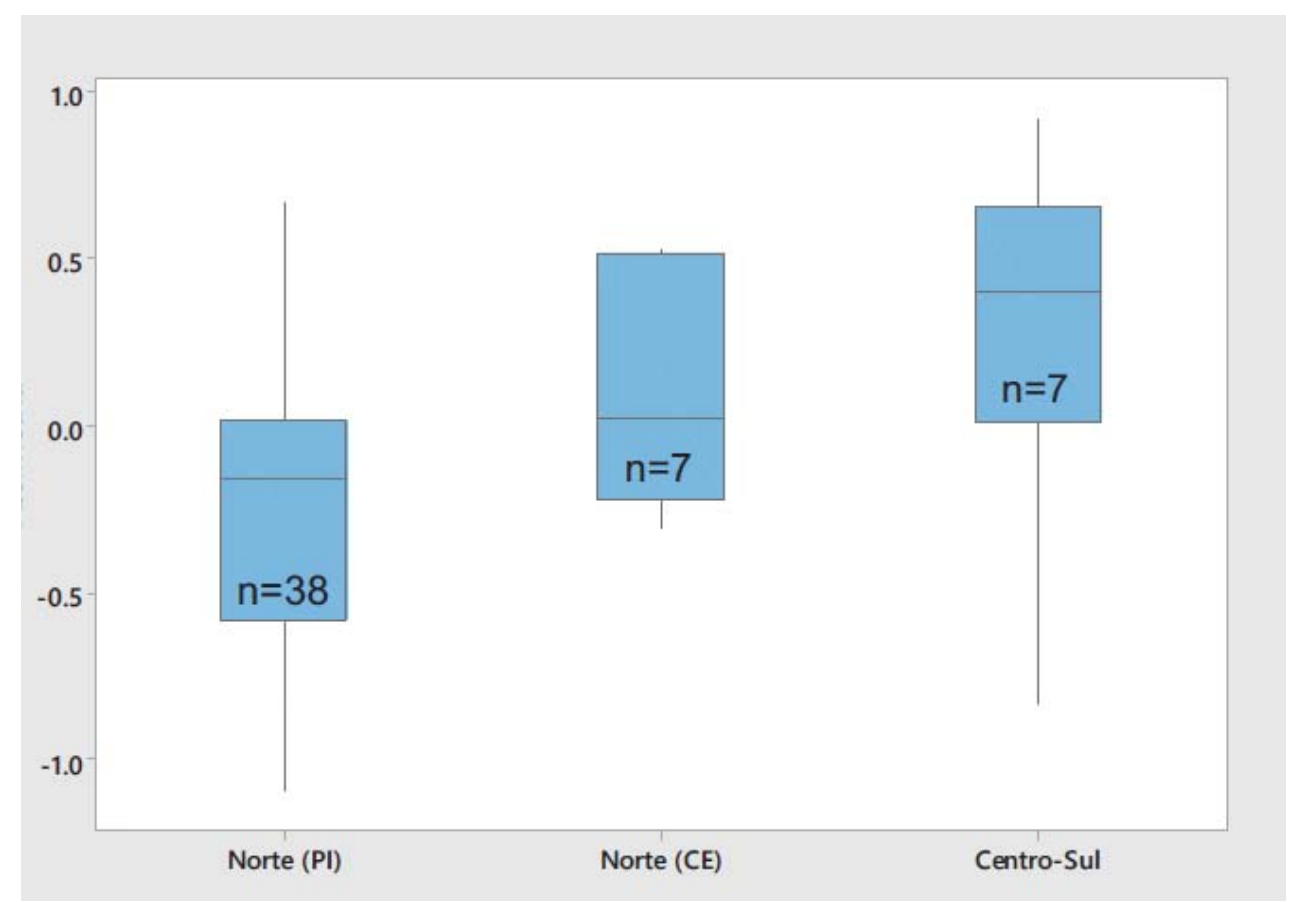

Figura 7.3. Diagrama em caixa para variação da assimetria da distribuição granulométrica dos eolianitos, segundo três setores geográficos de norte para sul.

No conjunto, as amostras das três fácies deposicionais apresentam valor médio de diâmetro médio de 1,8 (areia média), com mínimo de 0,7 (areia grossa) e máximo de 
2,6 (areia fina) (Figura 7.4). As fácies $\mathbf{A c}_{\mathbf{b}}$ e $\mathbf{A} \mathbf{c}_{\mathbf{a}}$ possuem intervalos interquartis quase idênticos entre si, pouco mais largos e cerca de 0,3 mais finos que o da fácies $\mathbf{A c}_{\mathbf{b}} \mathbf{r}_{\mathbf{a}}$ (Figura 7.1). A fácies $\mathbf{A c}_{\mathbf{a}}$ apresenta mediana do diâmetro médio mais fina (2,2 ) que $\mathbf{A c}_{\mathbf{b}}$ e $A \mathbf{c}_{b} \mathbf{r}_{\mathbf{a}}(1,8$ e 1,7 , respectivamente).

Quanto ao desvio padrão da distribuição granulométrica, o intervalo interquartis dos eolianitos correspondentes a estas três fácies varia entre cerca de 0,7 e 1,1 , com média de 0,9 . O intervalo interquartis é mais estreito (menos de 0,1 ) em $\mathbf{A c}_{\mathbf{a}}$ que nas outras duas fácies (mais de 0,3 ), sugerindo maior homogeneidade interamostral. Nota-se tendência de aumento do quartil superior, e, portanto, da presença de amostras menos selecionadas granulometricamente, da fácies $\mathbf{A c}_{\mathbf{a}}$ para a $\mathbf{A} \mathbf{c}_{\mathbf{b}}$ e daí para a $\mathbf{A} \mathbf{c}_{\mathbf{b}} \mathbf{r}_{\mathbf{a}}$ (Figura 7.5).

$\mathrm{O}$ intervalo interquartis da assimetria da distribuição granulométrica das amostras das três fácies selecionadas oscila entre $-0,8$ e 0,5 ; as amplitudes de variação são semelhantes, com tendência de aumento dos valores, tanto da mediana quanto dos quartis, da fácies $\mathbf{A} \mathbf{c}_{\mathbf{a}}$ para $\mathrm{Ac}_{\mathrm{b}}$ e desta para $\mathbf{A} \mathbf{c}_{\mathbf{b}} \mathbf{r}_{\mathbf{a}}$. $\mathbf{A} \mathbf{c}_{\mathbf{a}}$ apresenta assimetria entre muito negativa $(<-0,5)$ e nula, enquanto as demais variam entre assimetrias pouco negativas, nulas e pouco positivas (Figura 7.6).

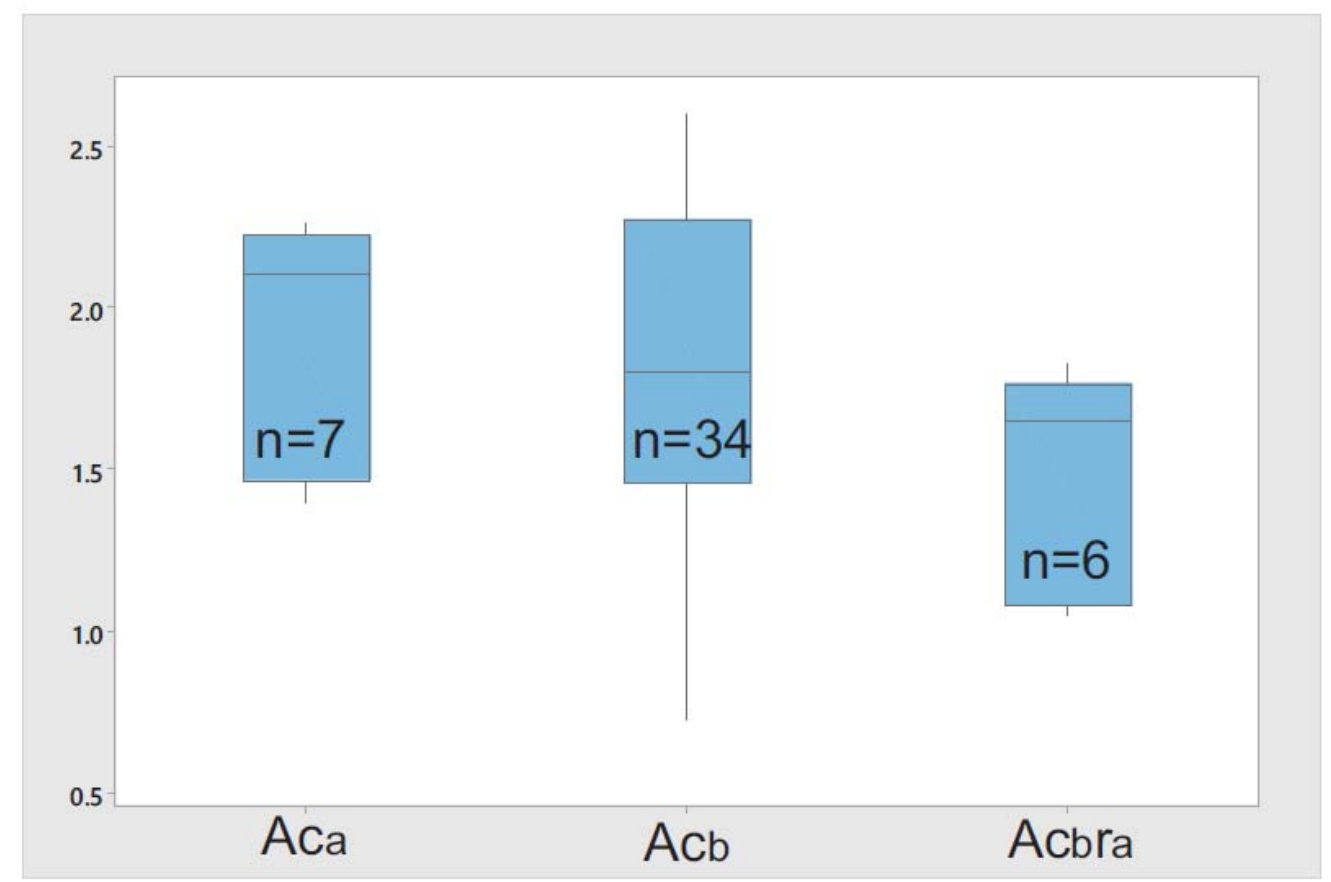

Figura 7.4. Diagrama em caixa para variação do diâmetro médio da distribuição granulométrica em phi nas três fácies mais comuns dos eolianitos. 


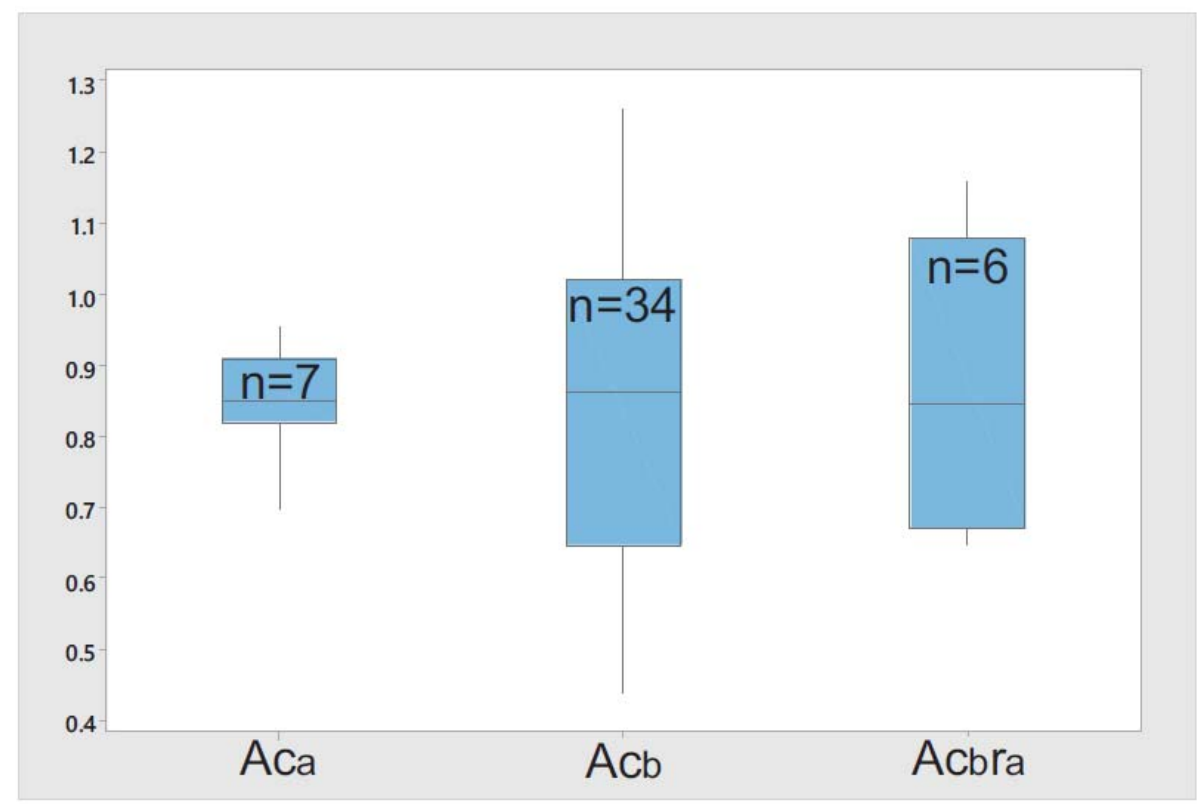

Figura 7.5. Diagrama em caixa para variação do desvio padrão da distribuição granulométrica em phi nas três fácies mais comuns dos eolianitos.

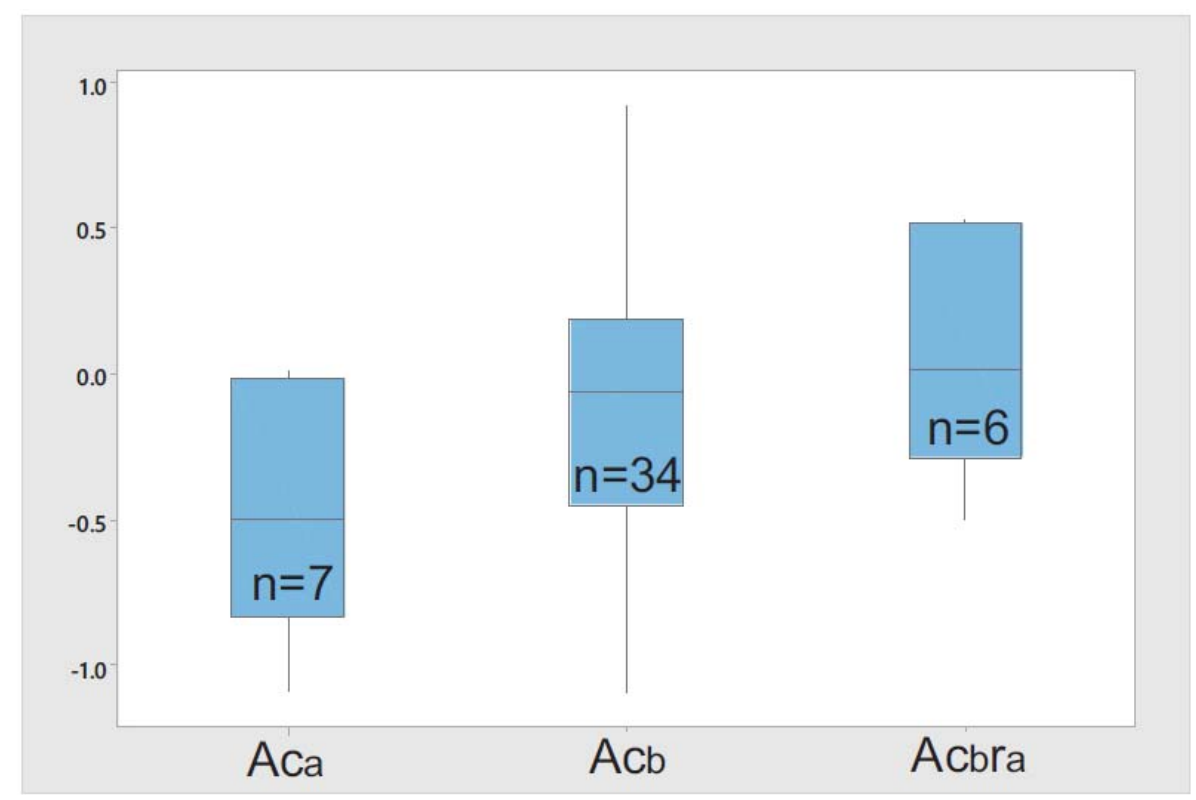

Figura 7.6. Diagrama em caixa para variação da assimetria da distribuição granulométrica nas três fácies mais comuns dos eolianitos. 


\subsubsection{Análise petrográfica}

Das 45 lâminas petrográficas analisadas, 37 correspondem a eolianitos e oito a outros tipos de depósitos associados.

\section{- Eolianitos}

Todos os eolianitos são clasto-suportados, alguns com granulometria modal na classe areia média, e outros com granulometria bimodal dentro do intervalo entre as classes areia grossa e areia fina; a seleção granulométrica visualmente estimada varia entre boa e moderada e os grãos de quartzo são subangulares a subarredondados, de esfericidade alta a média (Figura 7.7).

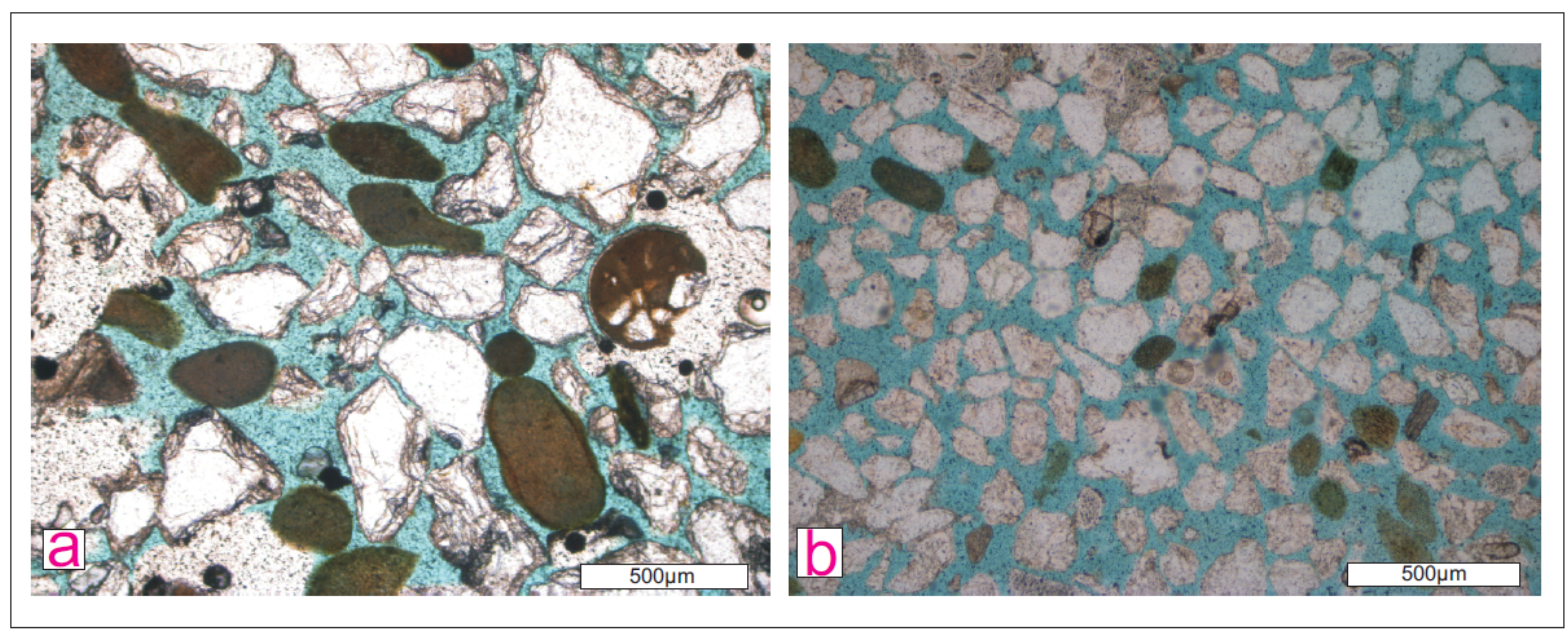

Figura 7.7. Aspecto geral do arcabouço dos eolianitos: predomínio de grãos de quartzo de esfericidade alta a média, subarredondados a subangulares, com presença subordinada de bioclastos arredondados, sobretudo de algas vermelhas: a. amostra EPI39E da fácies $A_{c_{b}} r_{a}$, com granulometria bimodal areia fina e areia média, tanto nos bioclastos quanto nos grãos de quartzo; $\mathbf{b}$. amostra EPI08Eb, da fácies $\mathrm{Ac}_{\mathrm{b}}$, com moda principal em areia fina. A cor azul corresponde aos poros originais.

Em relação à mineralogia do arcabouço, os eolianitos apresentam composição essencialmente quartzosa (50-65\%), com proporções menores de carbonato, ocorrente como bioclastos $(10-20 \%)$ e intraclastos $(<5 \%)$, e de outros minerais terrígenos, com destaque maior para feldspatos (2-5\%) (Figura 7.4). O quartzo está presente nas suas formas poli e monocristalina, esta última a mais comum, com extinção simples; os bioclastos são representados principalmente, em ordem decrescente de porcentagem, por algas vermelhas, foraminíferos bentônicos, fragmentos de moluscos, cracas, equinodermas, inclusive crinoides e espinhos de equinoides, e corais (Figura 7.8 e 7.9). O cimento (5$15 \%$ ) é dominado por carbonato (Figuras 7.10 a 7.12). 

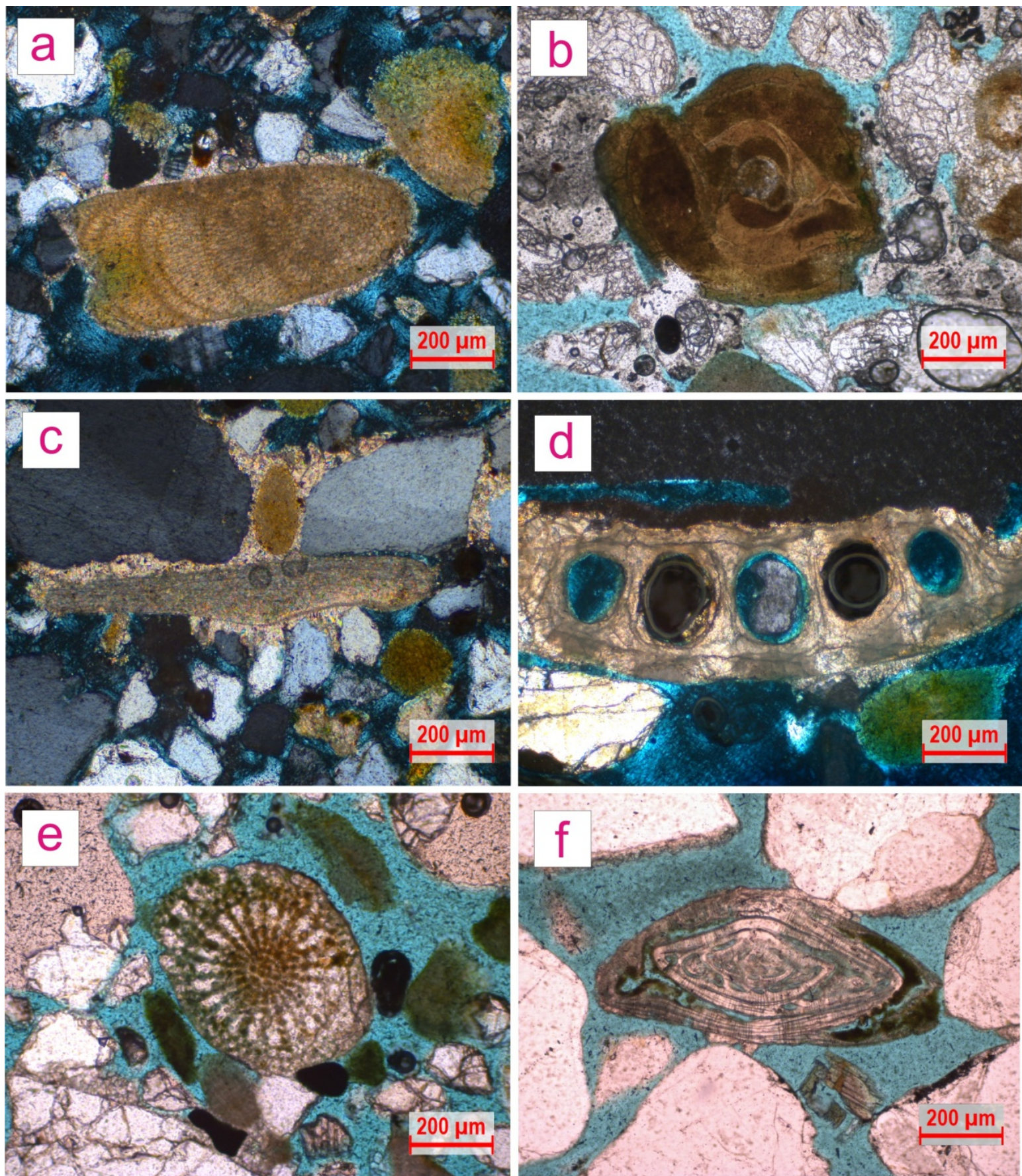

Figura 7.8. Tipos de bioclastos mais comuns nas lâminas de eolianito: a. alga vermelha (coralinacea); b. foraminífero bentônico (miliolida); c. fragmento de molusco (provável bivalve); d. craca; e. espinho de equinoide; f. foraminífero bentônico (nummulites). Amostras a a e, da área de Macapá (PI), e f de Trairi (CE). Fotomicrografias a, c e d a nicóis cruzados; demais, a nicóis paralelos. 

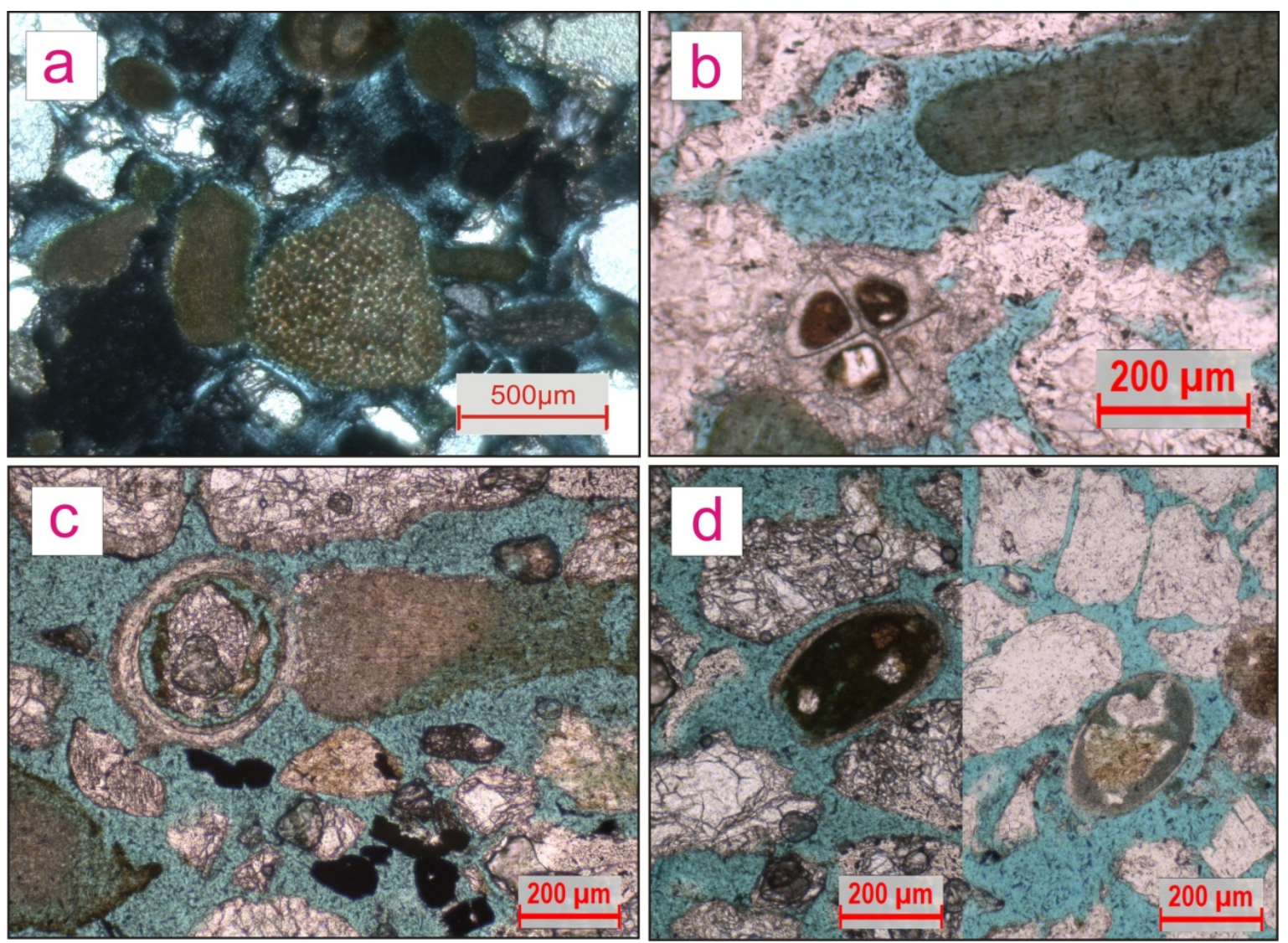

Figura 7.9. Outros clastos intrabacinais ou bioturbações observados nas lâminas de eolianito: a. equinoderma (possível crinoide); b. coral; c. poliqueta ou rizoconcreção com grão de quartzo no interior; d. poliquetas, vermetídeos ou rizoconcreções preenchidos por cimento ferruginoso (esquerda) e micritico (direita). Amostra a da área de Macapá (PI), b e d, de Carnaubinha (PI), e c, de Trairi (CE). Fotomicrografias a a nicóis cruzados e as demais a nicóis paralelos.

No que se refere às propriedades de petrotrama, observa-se em algumas amostras da fácies $\mathbf{A} \mathbf{c}_{\mathbf{a}}$, segregação granular quanto a tamanho, forma e composição, além de orientação de grãos alongados, principalmente de algas vermelhas (Figura 7.10a). O empacotamento dos eolianitos, avaliado segundo o índice de proximidade de Kahn (1956), é aberto a, mais raramente, normal (IP entre 25 e 45\%), com contatos intergranulares dominantemente pontuais a ausentes (grãos flutuantes; Figura 7.10b). 

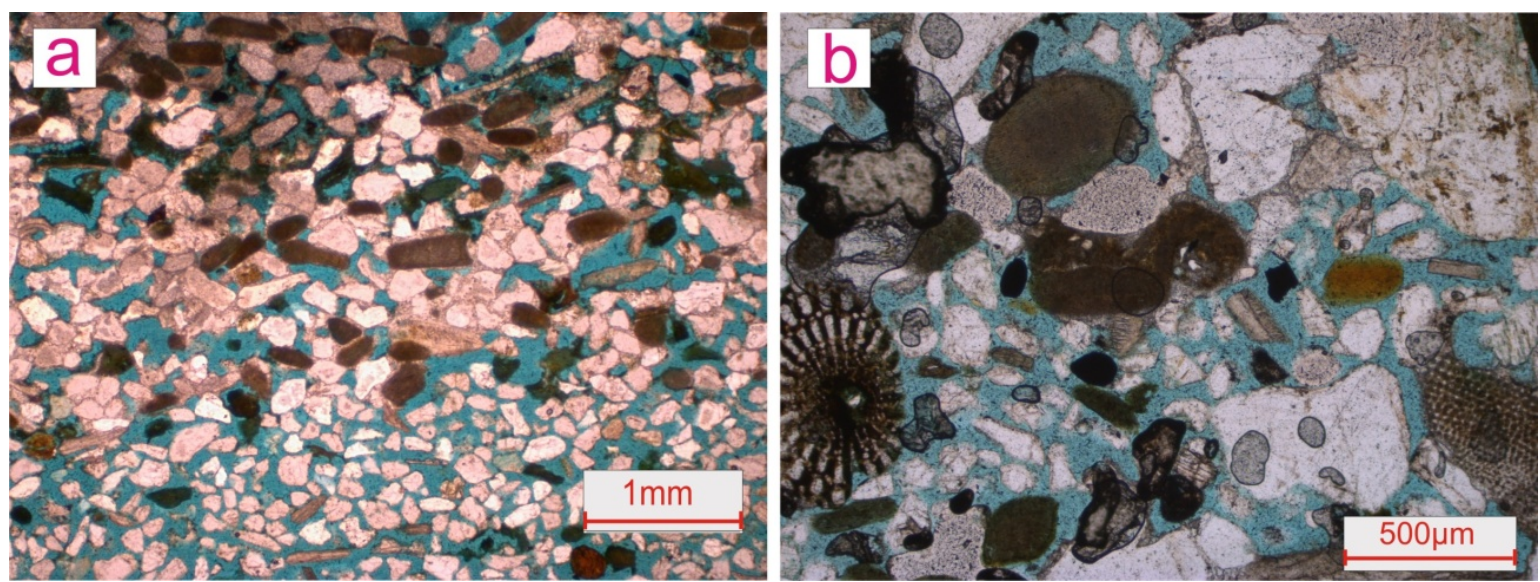

Figura 7.10. Diferenças de trama entre as fácies $A c_{a}$ e $A c_{b}$ : a. segregação granular quanto a tamanho, forma e composição, e orientação subparalela de clastos e, principalmente de bioclastos, na fácies $A c_{\mathrm{a}}$ da área de Carnaubinha; $\mathbf{b}$. empacotamento aberto com grãos flutuantes associado a bimodalidade granulométrica sem segregação nítida, na fácies $\mathrm{Ac}_{\mathrm{b}}$ da área de Macapá. Fotomicrografias a nicóis paralelos.

O cimento de carbonato de cálcio encontra-se nas dimensões microespática e, em menor abundância, micrítica e espática. Ele ocorre como película ou franja envolvente nas bordas dos grãos siliciclásticos, e, preferencialmente, nas dos bioclásticos, e, em menor proporção, como revestimento ou preenchimento parcial dos espaços intergranulares (Figuras 7.11 a 7.13). A franja envolvente apresenta-se mais comumente anisópaca (Figuras 7.11a e 7.11c), mas também isópaca (Figura 7.11b), podendo apresentar linhas medianas ligeiramente suturadas (Figura 7.11d), todas feições sugestivas de cimentação anterior à compactação. Outras tramas de cimento carbonático comumente encontradas são a em menisco (Figura 7.12a), as franjas anisópacas mais espessas junto à borda inferior dos grãos, em padrão pendular (Figura 7.12b), e a micronodular, concentrada ao longo de zonas subverticais (Figura 7.12c) ou junto a bioclastos e/ou grãos mais finos (Figura 7.12d). Elas sugerem precipitação de solutos a partir de fluidos intersticiais presos por tensão superficial ou em ascensão ou descenso. 

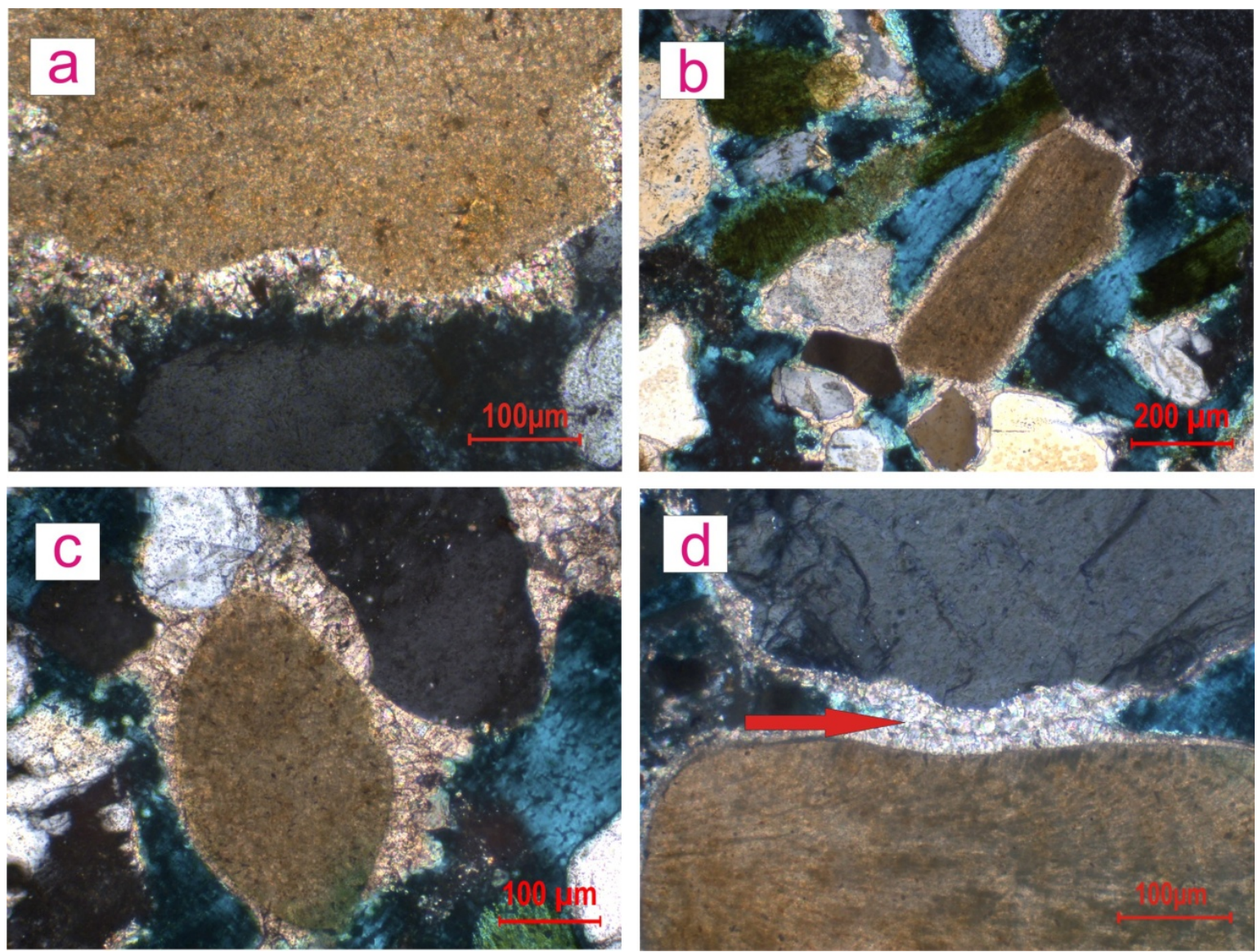

Figura 7.11. Feições características de cimentação microespática anterior à compactação, observadas a nicóis cruzados: a a c. franjas envolventes, anisópacas (a, c) ou isópacas (b); d. sulco mediano (indicada pela seta vermelha), ligeiramente suturado, no encontro dos cimentos envolventes de dois clastos adjacentes. Amostra a e d, de Macapá (PI); b e c de Carnaubinha (PI). 

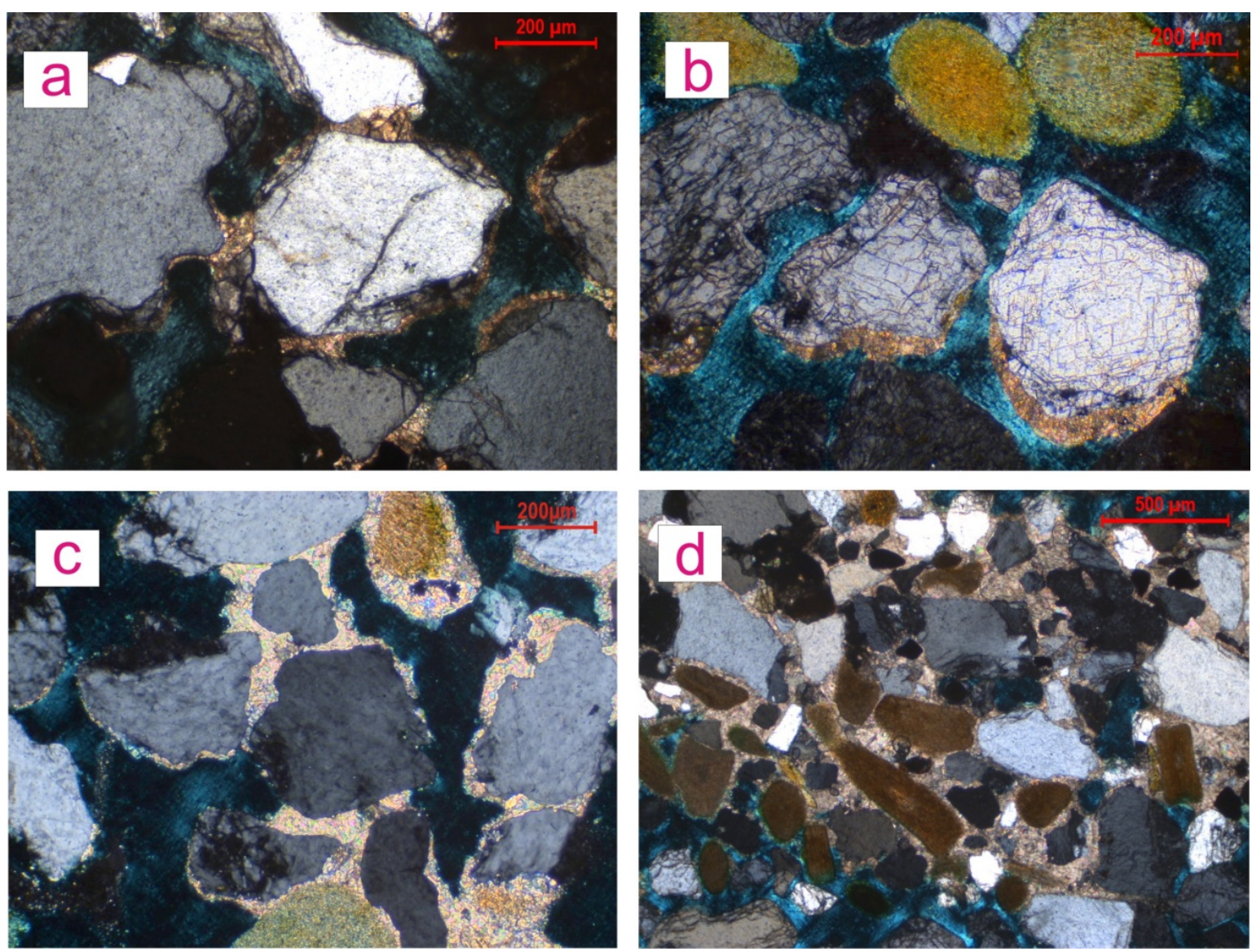

Figura 7.12. Arranjos de cimento carbonático ligados a tensão superficial ou ascensão ou descenso de fluidos intersticiais, em fotomicrografias a nicóis cruzados: a. espato em menisco entre grãos de quartzo; b. microespato pendular (geopetal); c. espato distribuído ao longo de zona subvertical; e d. espato concentrado preferencialmente junto a bioclastos e clastos menores. Amostra a, de Paracuru (CE); b e d, de Itaqui (CE); e c de Carnaubinha (PI).

Outros tipos de textura e trama de cimento carbonático observados em menor proporção são o preenchimento intergranular espático em mosaico (Figura 7.13a), a franja anisópaca de revestimento de poro (Figuras 7.13b e 7.13c), a franja anisópaca acicular microporosa em torno de bioclastos, principalmente moluscos (Figura 7.13d), e o preenchimento intragranular, em especial em miliolídeos (Figura 7.13e). Em alguns casos, encontrou-se mais de uma geração de cimento, com sucessão entre franja isópaca e franja anisópaca (Figura 7.13c), ou com franja seguida de preenchimento intersticial ou de revestimento de poro, em arranjo drusiforme (aumento de tamanho de cristal para o centro do poro). A segunda geração de cimento, quando espática de preenchimento de poro, apresenta às vezes padrão em mosaico. 

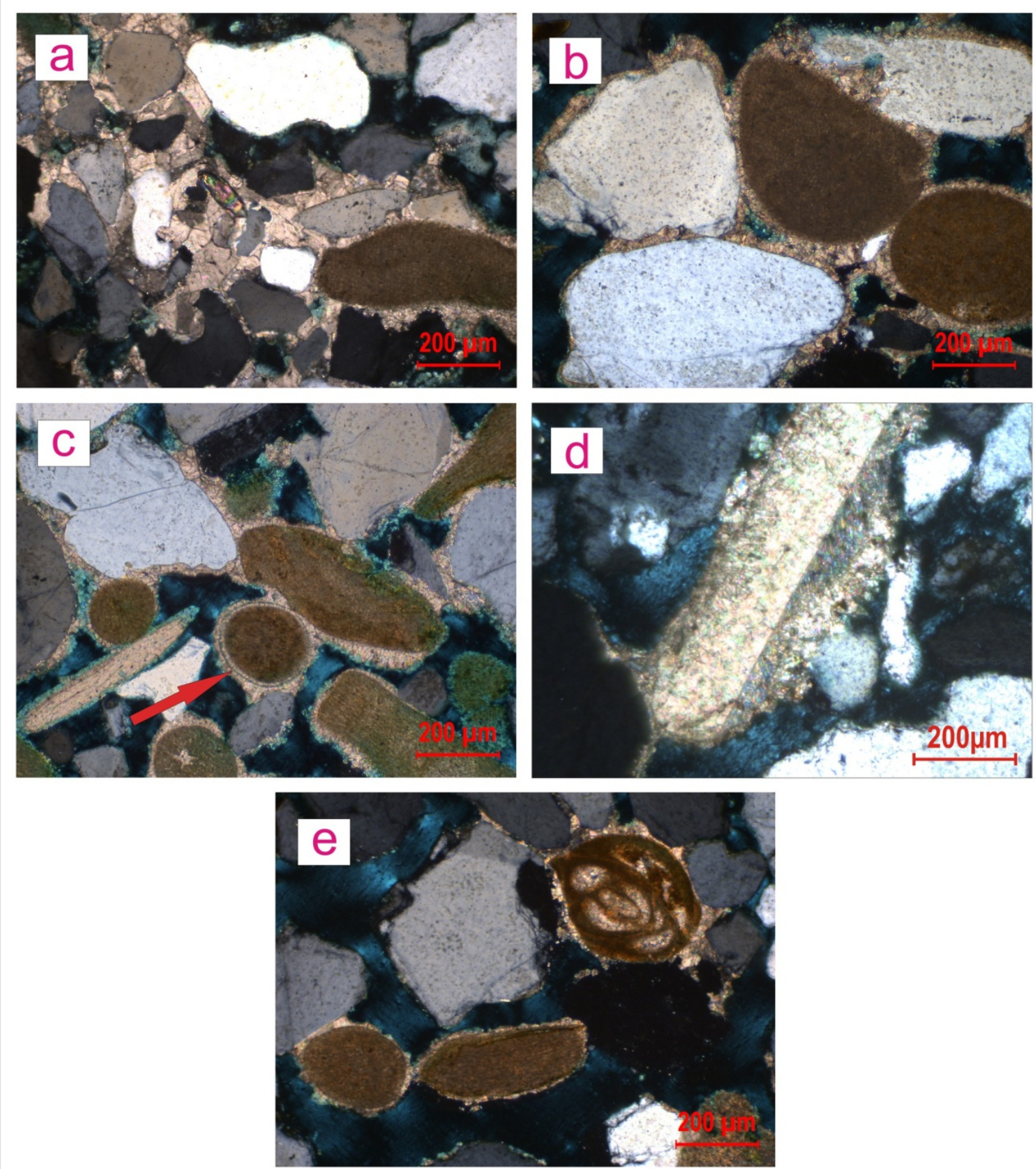

Figura 7.13. Outros arranjos de cimento carbonático presentes nos eolianitos, em fotomicrografias a nicóis cruzados: a. espato em mosaico; b. franja anisópaca de revestimento de poro; c. duas gerações de cimento, franja isópaca (primeira geração) e revestimento de poro anisópaco (segunda geração), com a seta indicando a linha mediana entre elas; d. franja anisópaca, com porosidade intercristais, sobre fragmento de bivalve; e e. cimentação intragranular em miliolídio. Amostras a, c e e, da área de Carnaubinha (PI); b, de Trairi (CE); e d, de Macapá (PI). 
A composição do cimento verificada por DRX é calcítica, e, nos mapas de elementos obtidos ao MEV-EED, não se observaram variações expressivas nas concentrações de $\mathrm{Mg}$ (Figura 7.14). A tonalidade de cinza na imagem de elétrons retroespalhados do cimento é mais clara que a dos bioclastos de rodofíceas (calcita magnesiana), indicando tratar-se de calcita pobre em magnésio.
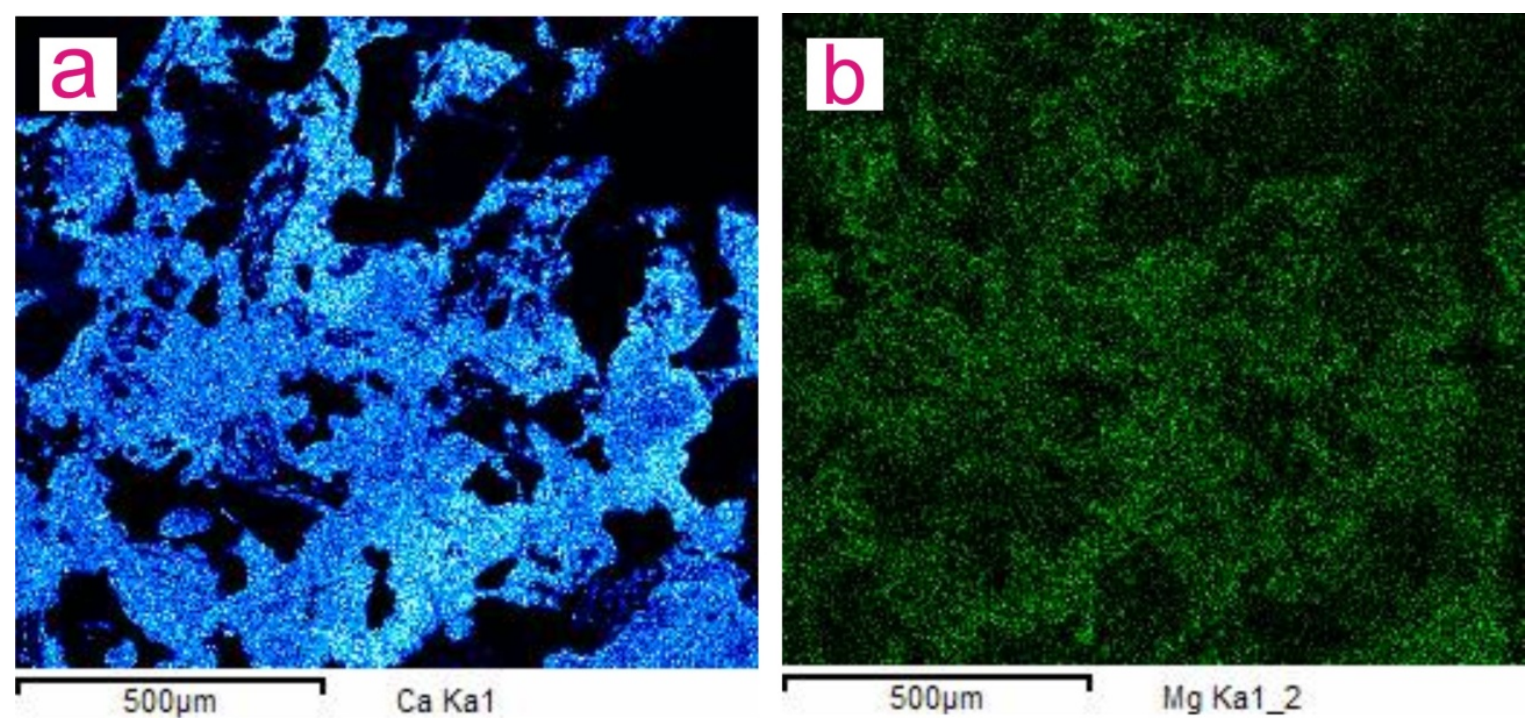

Figura 7.14. Mapas de concentração de elementos químicos na lâmina ECE49E: a. Ca, ressaltado em cor azul; b. $\mathrm{Mg}$, em cor verde. Preto indica ausência dos elementos. Notar que a presença de $\mathrm{Mg}$ restringe-se às zonas com presença de $\mathrm{Ca}$, mas em tons mais escuros, o que sugere baixos teores do elemento.

A porosidade, segundo a classificação de Choquette e Pray (1970) é seletiva, principalmente intergranular (Figura 7.15), e em proporções subordinadas, intragranular e móldica, estas duas últimas presentes em bioclastos como gastrópodes e foraminíferos. (Figura 7.15c). 


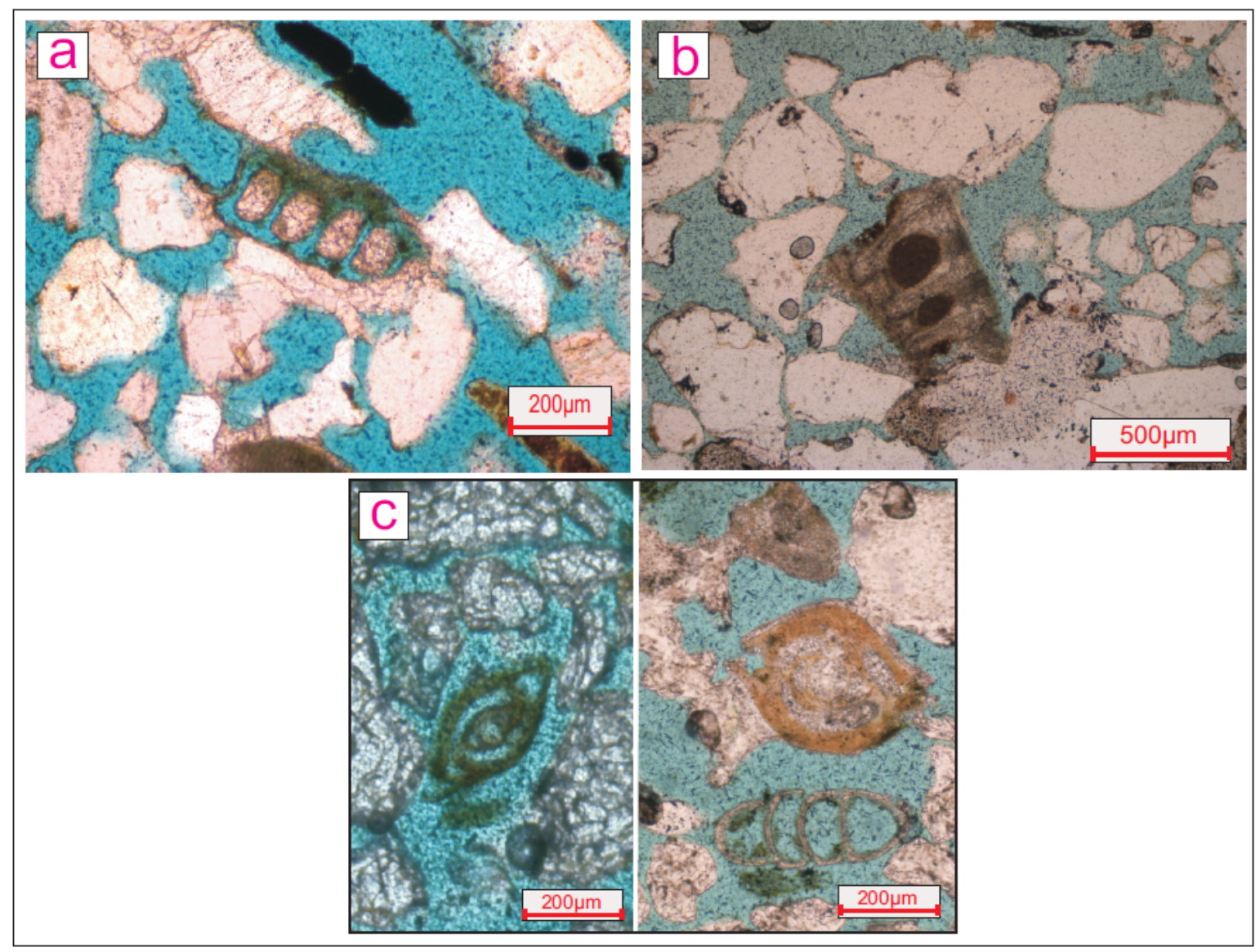

Figura 7.15. Feições de porosidade, cimentação e compactação em lâminas de eolianito a nicóis paralelos: a. porosidade móldica, evidenciando a dissolução parcial de um bioclasto; b. contatos intergranulares pontuais; indicativos de baixa compactação; c. porosidade intragranular em foraminífero miliolídeo (esquerda) e em gastrópode (direita) e cimentação intragranular em miliolídeo (direita). Amostra a da área de Carnaubinha (PI); b, de Paracuru (CE); e c, de Macapá (PI).

Numa classificação adaptada de Folk (1959, 1962), para calcários, e de Dott (1964), para arenitos terrígenos, os eolianitos foram classificados como quartzo arenitos bioespatitos ou quartzo arenitos biomicritos.

- Depósitos associados aos eolianitos

As oito amostras de depósitos associados aos eolianitos estudados petrograficamente correspondem a cinco fácies descritas previamente no Artigo 1 (Quadro 5): calcirrudito bioclástico maciço com gastrópodes marinhos (Rg); arenito com laminação plano-paralela rico em bioclastos rudáceos (Apb); quartzo arenito e rudito interestratificados com rizoconcreções abundantes no topo $\left(\mathbf{R A} \mathbf{r}_{\mathbf{a}}\right)$; rudito polimítico maciço, com ou sem ferricretes (Rm); e quartzo arenito médio a fino, maciço, com gastrópodes continentais dominantemente inteiros, de diferentes tamanhos (Amg).

A amostra da fácies Rg (Figura 7.16), proveniente da área de Camocim (CE), classifica-se como quartzo arenito (Dott 1964, Folk 1968), com grãos flutuantes de quartzo e moluscos; ela é composta principalmente por quartzo monocristalino (50\%), em grãos 
subangulares, de esfericidade boa e moderadamente selecionados, e por gastrópodes geralmente inteiros. Apresenta cimento espático e microespático, no preenchimento de espaços intergranulares.
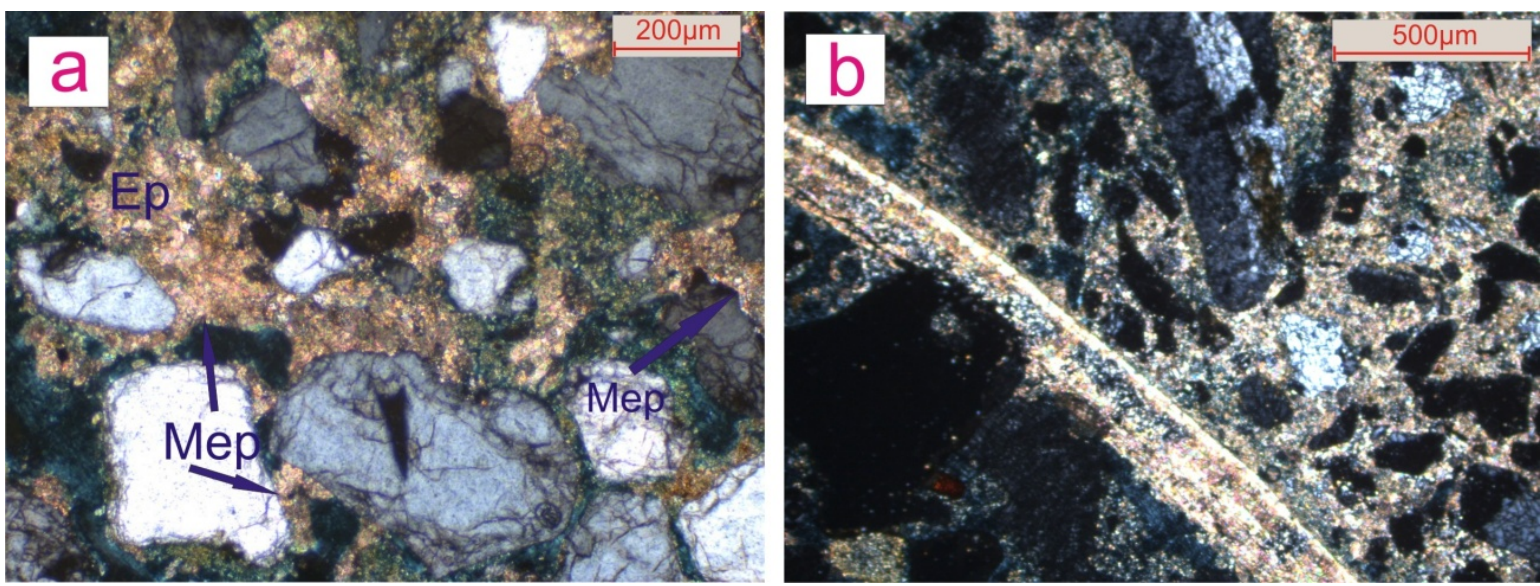

Figura 7.16. Quartzo arenito da fácies Rg (lâmina ECE49con) a nicóis cruzados: a. cimentos de espato (Ep) e microespato (Mep), bordejando e unindo clastos de quartzo moderadamente selecionados; b. fragmento de gastrópode, em meio a grãos terrígenos cimentados por microespato.

Duas lâminas correspondentes a "beach-rocks" (fácies Apb) classificam-se como grainstone (Dunham 1962) impuro ou quartzo arenito bioespatito (Folk 1962), com grãos que vão desde areia grossa até areia fina, subangulares, de baixa esfericidade e pobremente selecionados (desvio padrão $=1,9$ ); o arcabouço é principalmente de quartzo mono e policristalino (50-60\%) e bioclastos (10-15\%) de algas vermelhas, moluscos e cracas. $\mathrm{O}$ cimento (20-30\%) é de microespato e espato, com arranjos em mosaico e franja anisópaca, em pêndulo e menisco (Figura 7.17). 

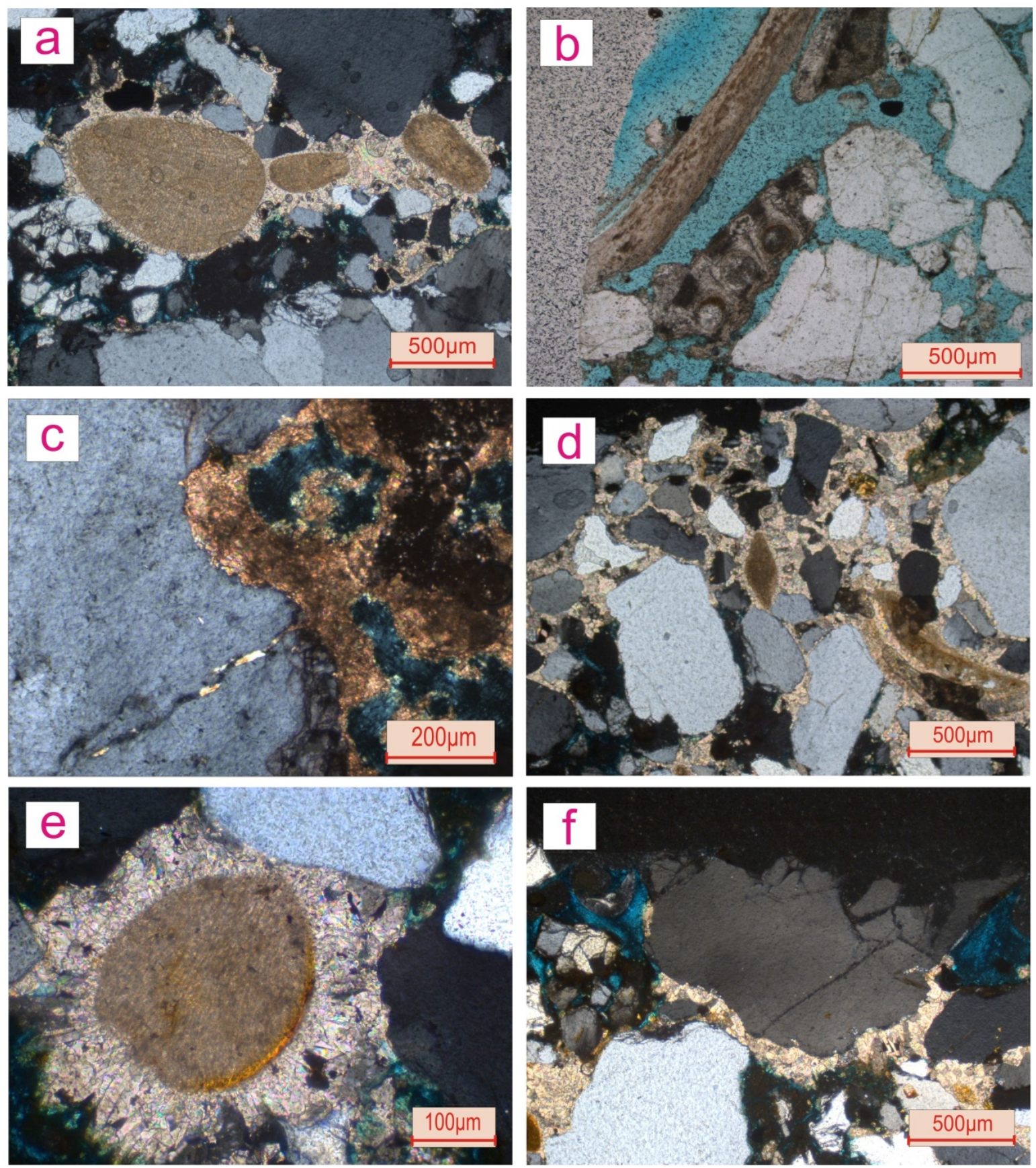

Figura 7.17. Componentes presentes nas amostras de beach-rocks, fácies Apb: a. bioclastos arredondados de algas vermelhas e clastos subangulosos mal selecionados de quartzo; b. bioclastos de bivalve e craca, junto a grãos subangulosos de quartzo; c. cimento de microespato junto a grão de quartzo; d. cimento de espato bordejando clastos e bioclastos e. cimento em franja anisópaca; e f. cimento pendular. Lâminas a, e e f de amostras coletadas em Bitupitá (CE) e b, c e d de Camocim (CE). Fotomicrografia $\mathbf{b}$ a nicóis paralelos; as demais, a nicóis cruzados.

A lâmina ECE51PB corresponde à fácies $\mathbf{R A r}_{\mathbf{a}}$ e à unidade informalmente denominada "pós-Barreiras". Esta fácies alterna estratos rudáceos e arenáceos e a seção delgada foi feita na porção mais arenácea, porém com grânulos e pequenos seixos. Trata-se de depósito clasto-suportado, composto por quartzo (80\%), principalmente policristalino, e em menores proporções, por feldspatos (5\%). Os grãos são subarredondados, de boa esfericidade e com seleção granulométrica pobre (desvio padrão $=1,2$ ). A porosidade é 
intragranular (10\%) e o cimento, de microespato (5\%), bordeja clastos e previne o empacotamento, o qual, segundo o índice de Kahn (1956), é aberto ( $\mathrm{IP}=25 \%$ ), com contatos pontuais (Figura 7.18). A rocha classifica-se como quartzo arenito, segundo Dott (1964) e Folk (1968).

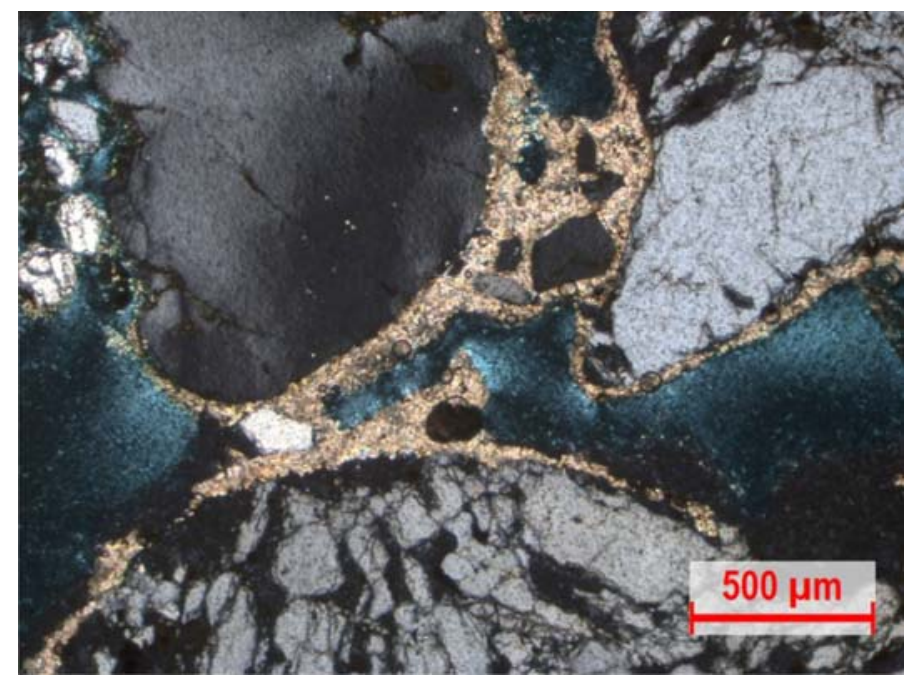

Figura 7.18. Arenito com grãos de quartzo monocristalino mal selecionados, cimentado por microespato. Fotomicrografia a nicóis cruzados da amostra ECE51PB, "pós-Barreiras" da área de Maceió (CE).

Uma amostra da matriz arenácea da fácies Rm (Formação Barreiras, ECE47FB) foi analisada petrograficamente e classificada como quartzo arenito (Dott 1964, Folk 1968), com grãos de quartzo poli e monocristalinos (60\%), subangulares, medianamente esféricos e muito mal selecionados (desvio padrão $=2,3 \quad$ ); o cimento é de filossilicato (30\%) bordejando os clastos, e a porosidade (10\%) é intragranular (Figura 7.19).

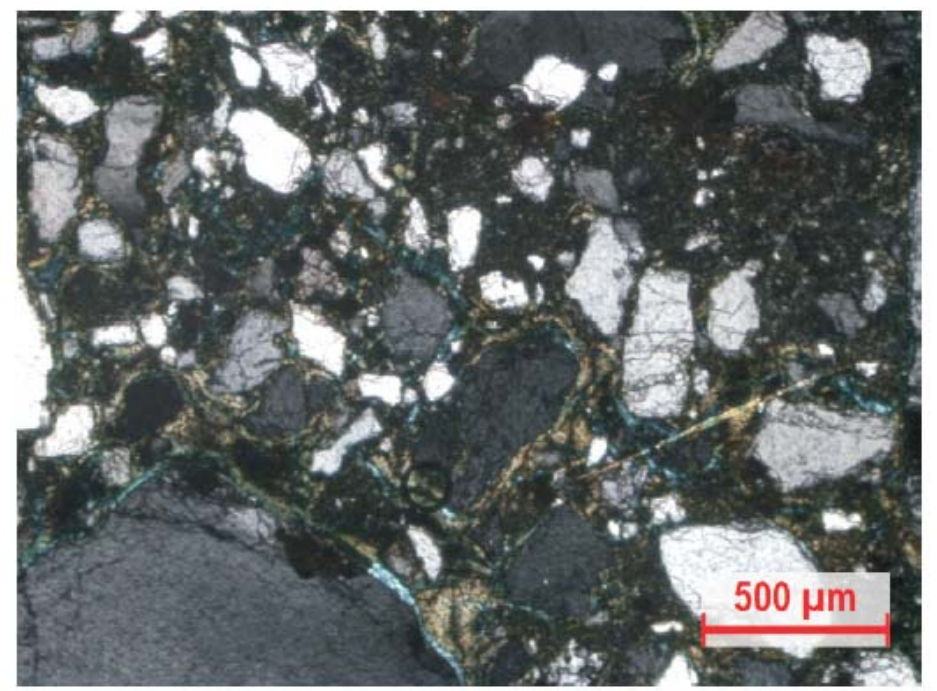

Figura 7.19. Quartzoarenito da Formação Barreiras (amostra ECE47FB), com grãos subangulares, medianamente esféricos e muito mal selecionados, e cimento de filossilicato. 
Nas três lâminas de amostras provenientes da região de Luís Correia (PI), fácies Amg (Figura 7.20), o arcabouço é composto principalmente por quartzo monocristalino (30-50\%) e por conchas inteiras e fragmentadas de gastrópodes (10\%). Possui empacotamento aberto e contatos intergranulares tangenciais. Os grãos de quartzo são de areia fina a média, esféricos a subesféricos, subangulares a subarredondados e bem selecionados; o cimento é intergranular, tanto carbonático, de textura micrítica e microespática (20-35\%), quanto de óxi-hidróxido de ferro (10-15\%). Neste segundo caso, apresenta distribuição heterogênea (Figura 7.20b), sugerindo a formação de nódulos preferencialmente associados aos gastropódes. Grumos ou micropeloides de cimento micrítico ou organo-ferruginoso também podem estar presentes. O depósito foi petrograficamente classificado como quartzo arenito (Dott 1964, Folk 1968).

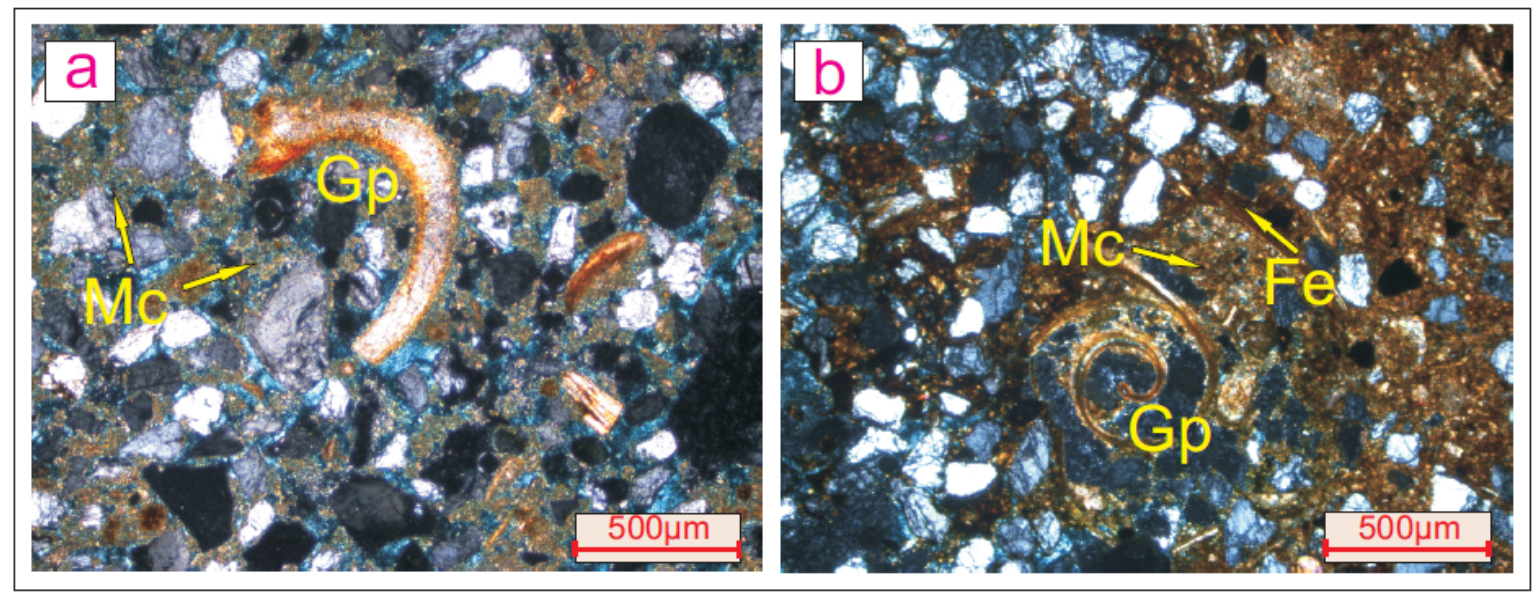

Figura 7.20. Quartzo arenito com gastrópodes (fácies Amg) da área de Luís Correia, a nicóis cruzados: a. lâmina EPI43, com cimento micrítico bordejando os clastos de quartzo bem selecionados e um gastrópode $(\mathrm{Gp})$; b. lâmina EPI45, com cimentos de óxi-hidróxido de ferro $(\mathrm{Fe})$ e micrítico (Mc), preferencialmente associados ao entorno e ao interior de um gastrópode ( $\mathrm{Gp}$ ).

\subsubsection{Teor de carbonato}

Para ampliar a base de dados sobre o teor de carbonato, integraram-se as estimativas feitas a partir dos dados petrográficos com os resultados das análises químicas pelo método de dissolução com $\mathrm{HCl}$. Estes referem-se a 67 amostras, das quais 51 correspondem a eolianitos e 16 às praias e dunas de orla costeira representativas da área fonte do sistema eólico atual e, por premissa, similares às praias e dunas contemporâneas aos eolianitos.

Os teores em massa determinados por dissolução nas amostras de eolianitos, (Figura 7.21) apresentam intervalos interquartis que variam entre 8 e $26 \%$, no setor norte, e entre 8 e 18\%, nos setores centro e sul; nas amostras de praias e dunas atuais, os teores são menores (intervalo interquartis entre 4 e 17\%), à exceção das praias de Carnaubinha (área fonte para os eolianitos de Itaqui) e Almofala, onde os teores de carbonato mais elevados (até $22 \%$ ) se devem à presença de fragmentos mais grossos $(1-2 \mathrm{~mm})$ de conchas de moluscos (Figura 7.22). 


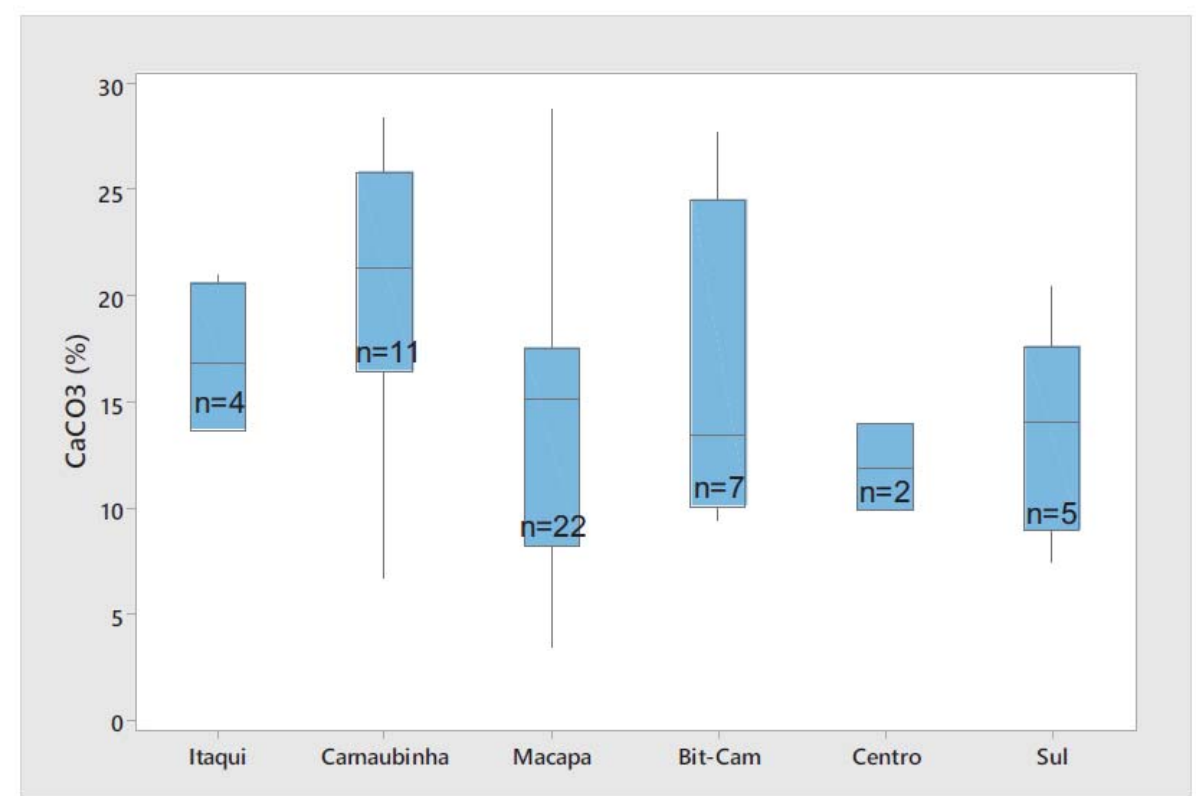

Figura 7.21. Teor de carbonato determinados por dissolução química de eolianitos, nos setores norte (Itaqui, Carnaubinha e Macapá no PI, e Bitupitá e Camocim no CE), centro (Itarema e Almofala, CE) e sul (Imboaca, Guajiru e Paracuru, CE).

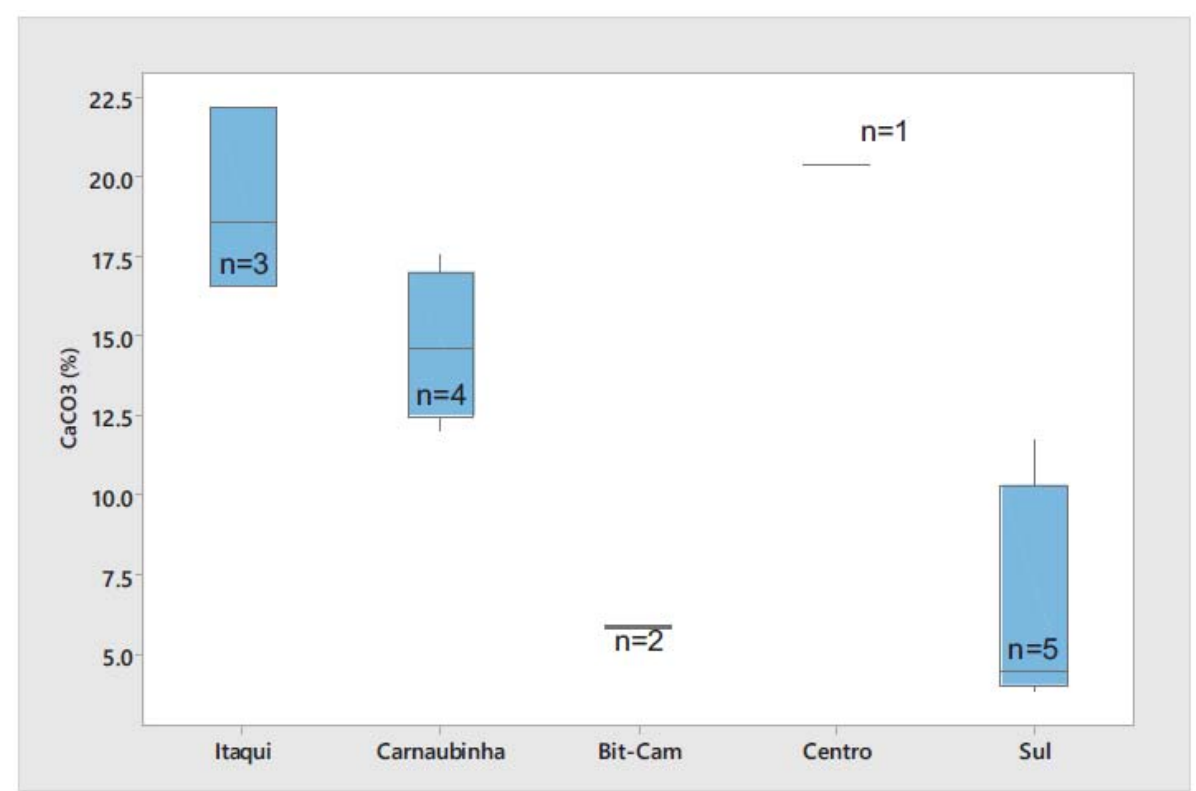

Figura 7.22. Teor de carbonato determinado por dissolução química de praias e dunas, nos setores norte (Itaqui e Carnaubinha, PI, e Bitupitá e Camocim, CE), centro (Almofala, CE) e sul (Imboaca, Guajiru e Paracuru, CE).

$\mathrm{Na}$ comparação dos resultados dos dois métodos de análise, por área geográfica (Figura 7.23), observa-se que, na quase totalidade dos casos, os dados petrográficos apresentam maiores teores de carbonato que os de ataque químico (exceções para Carnaubinha). Esta discrepância é oposta à esperada, já que na petrografía a estimativa do teor exclui a porosidade e é feita por área, e, por extensão, em volume, enquanto na análise por dissolução, o resultado é expresso em massa. Como o carbonato é mais denso que os demais componentes da rocha, esperava-se que o seu teor em massa fosse maior que o em 
volume. Uma explicação para esta discrepância é a porosidade intragranular ou intracristalina do carbonato. Enquanto os grãos de quartzo são maciços, os bioclastos e o cimento micrítico e microespático são frequentemente ocos ou micro-perfurados. Assim, a estimativa de carbonato ao microscópio resulta superestimada em relação ao seu teor em massa real, porque inclui volumes intragrão ou intercristais não preenchidos de fato.

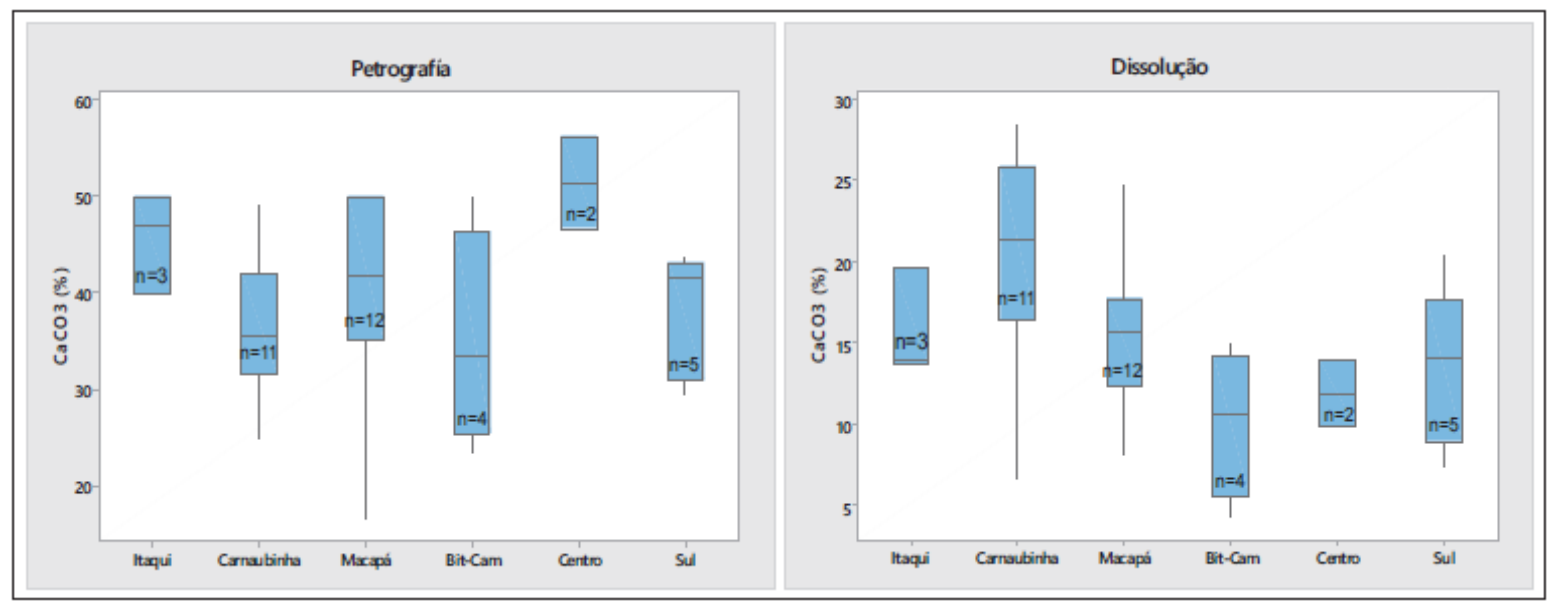

Figura 7.23. Diagramas em caixa comparando as análises de teor de carbonato pela petrografia e por dissolução dos eolianitos dos setores norte (Itaqui, Carnaubinha e Macapá no PI, e Bitupitá e Camocim no CE), centro (Itarema e Almofala, CE) e sul (Imboaca, Guajiru e Paracuru, CE).

Também se analisou o teor de carbonato dos eolianitos segundo as idades obtidas nas datações por AMS e LOE, onde se evidenciou que as amostras mais antigas apresentam teores menores (Figura 7.24). Isto sugere que houve eliminação de carbonato por dissolução ou aumento do aporte de material carbonático, bioclastos por exemplo, através do tempo. 


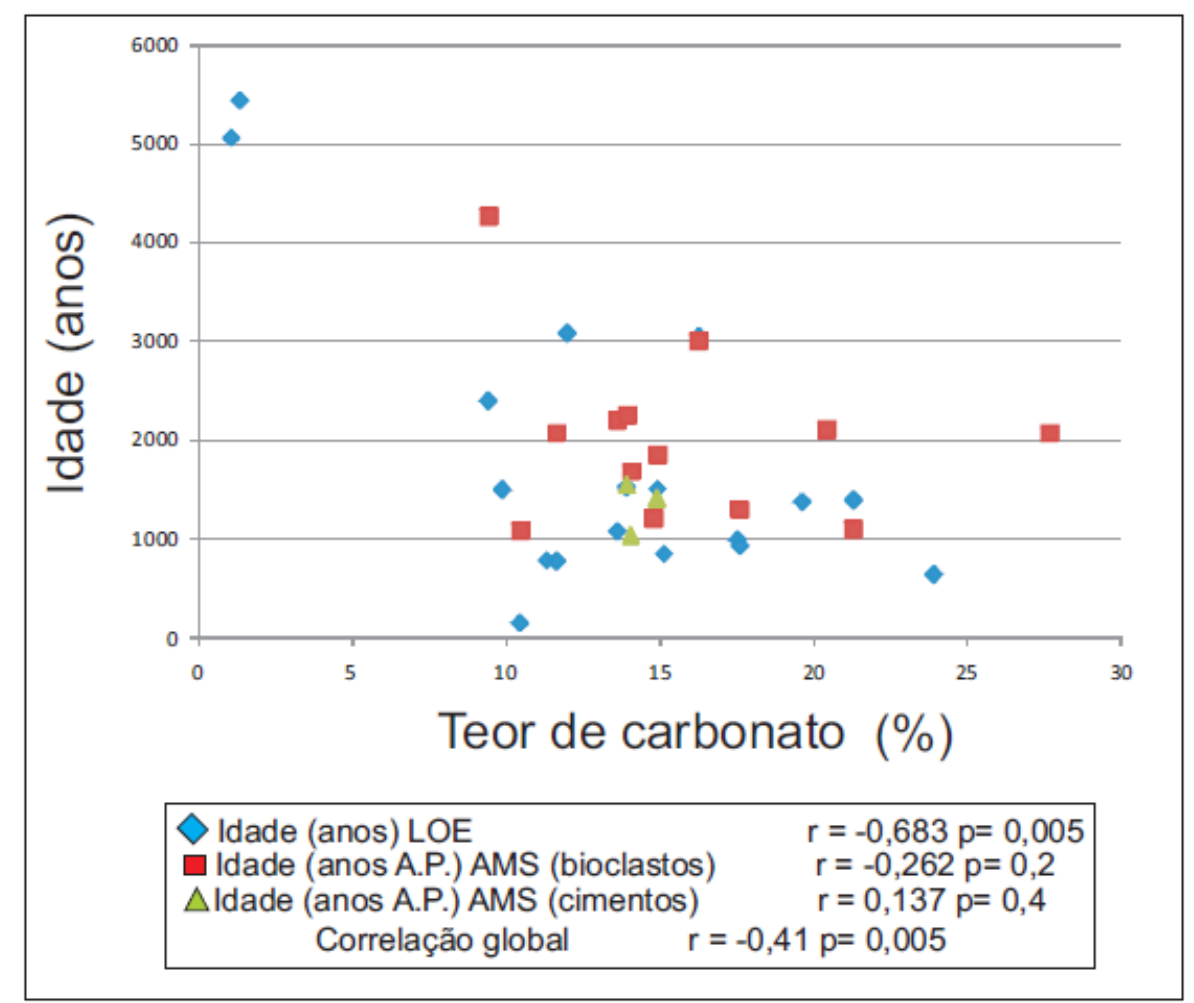

Figura 7.24. Gráfico de dispersão relacionando a idade com o teor de carbonato dos eolianitos.

\subsection{Discussão}

\subsubsection{Granulometria dos eolianitos e suas relações com as fácies morfológicas e a distância à fonte}

A sedimentação eólica nos eolianitos de Piauí e Ceará possui variações materializadas nas diferentes fácies morfológicas e deposicionais reconhecidas no Artigo 1. O desenvolvimento de cada fácies morfológica, por sua vez, está relacionado com a evolução do sistema eólico costeiro ao longo do tempo e com o crescimento gradativo da planície deflacionária, que é onde os eolianitos desta região se formam. Esta relação entre fácies, evolução do sistema e distanciamento da costa permite prever que haja relações também entre as propriedades sedimentológicas das fácies (e.g. granulometría) e as idades obtidas no Artigo 1 pelos métodos de LOE em grãos de quartzo e AMS em cimentos e bioclastos carbonáticos.

Cinco fácies principais foram diferenciadas no Artigo $1 \mathrm{com}$ base principalmente no ângulo de mergulho da estratificação e na presença de rizoconcreções: a fácies $\mathbf{A c}_{\mathbf{a}}$ foi atribuída a deposição por fluxo e queda de grãos nos flancos externos, íngremes, do rastro linear residual; a fácies $\mathbf{A c}_{\mathbf{b}}$ interpretou-se como produto da deflação no topo aplainado de rastro linear residual; a fácies $\mathbf{A c}_{\mathbf{a}} \mathbf{r}_{\mathbf{e}}$ refletiria a estabilização do flanco externo de rastro linear residual pela vegetação; a fácies $\mathbf{A} \mathbf{c}_{\mathbf{b}} \mathbf{r}_{\mathbf{a}}$ representaria a estabilização por vegetação do topo aplainado de rastro linear residual; e a fácies $\mathbf{A c}_{\mathbf{f}} \mathbf{r}_{\mathbf{a}}$, o avanço de blow-outs sobre 
antigas falésias costeiras, seguido pela estabilização por vegetação. Nas análises granulométricas realizadas nas praias e dunas atuais a barlavento dos eolianitos observouse que a seleção é moderada a pobre (desvio padrão variável de 0,5 a 1,2 ), com tamanho médio de grãos de quartzo e bioclastos carbonáticos desde areia muito grossa até areia fina. Já nos resultados de granulometría dos eolianitos agrupados segundo as fácies deposicionais predominantes, a fácies de estratificação cruzada de ângulo alto $\left(\mathbf{A c}_{\mathbf{a}}\right)$ apresenta tendência para tamanhos médios de grãos mais finos que a praia e que as demais fácies $(1,7$, em média), com maior homogeneidade interamostral, e melhor grau de seleção (desvio padrão de 0,6 a 1 ). Estas características são condizentes com a deposição seletiva de grãos mais finos, pelo vento, no flanco externo de rastros lineares residuais, hipótese levantada no Artigo 1 para a origem desta fácies. A fácies com estratificação cruzada de ângulo baixo $\left(\mathbf{A c}_{\mathbf{b}}\right)$, em contraposição, apresenta tamanho de grão areia média e seleção pobre a moderada (desvio padrão de 0,4 a 1,2 ), o que é compatível com sua origem por aplainamento das cristas dos rastros lineares residuais, após a migração prolongada das dunas parabólicas através da zona deflacionária. Na fácies de estratificação cruzada de baixo ângulo com rizoconcreções $\left(\mathbf{A c}_{\mathbf{b}} \mathbf{r}_{\mathbf{a}}\right)$ o tamanho médio de grãos passa a areia grossa, característica coerente com a acentuação dos processos deflacionários durante a estabilização do topo aplainado dos rastros pelo crescimento de vegetação; e o grau de seleção alcança seus piores valores, o que se explica pela presença associada de grossos residuais de deflação com grãos mais finos aprisionados pelas plantas.

A tendência, observada nos eolianitos rumo norte, para afinamento, distribuições granulométricas de assimetria mais negativa e com menor desvio padrão (este último avaliado pelas medianas do diagrama de caixa na comparação Piauí x Ceará) coincide com um dos dois padrões de variação espacial de granulometria indicadores de transporte sedimentar segundo McLaren \& Bowles (1986): o "mais fino, melhor selecionado e mais negativo". A observação deste padrão pode ser atribuída à herança da área fonte e/ou a diferenças de grau ou distância de transporte pelo vento. Na hipótese de herança da fonte, o padrão decorreria do efeito da deriva litorânea regional de E (Ceará) para W (Piauí). Na hipótese de efeito do transporte eólico, o padrão decorreria do distanciamento médio crescente, do Ceará para o Piauí, entre eolianitos e praia, conforme demonstrado no Artigo 1. A maior extensão no rumo do vento dos campos de dunas do Piauí, relacionada com o maior ângulo entre vento efetivo e linha de costa, tornaria os seus eolianitos mais distais, em relação à fonte costeira, em comparação com os do Ceará. Desse modo, os eolianitos do Piauí teriam maior distância de retrabalhamento pelo vento, daí a granulação mais fina, a seleção melhor e a moda assimétrica deslocada para o lado fino da distribuição (portanto, assimétrica negativa). 


\subsubsection{Petrofácies}

- Eolianitos

Para a distinção das petrofácies nos eolianitos (Quadro 6), tomaram-se como critérios os seguintes aspectos: 1. mineralogia dos componentes deposicionais, que, neste caso, é principalmente quartzosa $(\mathbf{Q}) ; 2$. número de modas granulométricas (modal: 1 ou bimodal: 2); e 3. microfeições dominantes de trama e/ou textura de cimento, subdivididas em seis tipos: franja (fr); revestimento de poro (r); concentração segundo micronódulos subverticais (sv); concentração em torno de grupos de bioclastos (b); gravitacional e/ou geopetal (g); e microespato em menisco (m). As siglas correspondentes a este terceiro critério (fr, $\mathbf{r}, \mathbf{s v}, \mathbf{b}, \mathbf{g}$ e $\mathbf{m})$ foram acrescentadas entre parêntesis ao final do código de petrofácies. Uma descrição mais pormenorizada de cada tipo de cimento é apresentada a seguir.

O cimento fr é dominantemente microespático, com textura em franja isópaca (fri), semi-isópaca (fr-si) ou anisópaca (fr-ai), geralmente envolvendo bioclastos de algas vermelhas, e, quase sempre, acompanhado de linha ou sutura mediana entre franjas de grãos adjacentes.

O tipo $\mathbf{r}$ resulta da precipitação de cimento microespático com trama de revestimento de poro, a qual se forma entre os espaços de grãos que estão em contato, geralmente pontual, entre si. É, portanto, indiretamente associado a um tipo de empacotamento sugestivo de alguma compactação.

Os cimentos sv e b são ambos micronodulares, isto é, localizados em porções preferenciais da rocha. Em sv, o carbonato microespático concentra-se em setores da rocha com tendência de distribuição vertical, o que permite interpretar fluxo de fluidos, seja descendente gravitacional, seja ascendente por capilaridade, ambos mais característicos de zona vadosa ou da interface vadoso-freático. Já o cimento b concentra-se em aglomerações de bioclastos carbonáticos, e preferencialmente em grãos mais finos. O cimento é microespático envolvente e a relação aparente dominante entre grãos e cimento é portanto de flutuação. A interpretação para a origem deste cimento é que ele foi reprecipitado a partir dos solutos gerados pela dissolução localizada da borda dos próprios bioclastos. Sua ocorrência preferencial em grãos finos pode estar relacionada tanto à maior superfície específica e, portanto, à maior reatividade dos bioclastos, quanto ao maior tempo de permanência das soluções reativas, por efeito da tensão superficial mais elevada nos poros menores, em condições vadosas.

O código $\mathbf{g}$ faz referência ao cimento microespático ou espático em textura gravitacional geopetal (isto é, indicadora da base da rocha), principalmente em torno de grãos de quartzo. Sugere cimentação a partir de água pendular, portanto em ambiente eodiagenético vadoso.

Finalmente, o cimento $\mathbf{m}$ caracteriza-se pela textura microespática com arranjo em menisco. Ocorre principalmente unindo as bordas de grãos de quartzo, mas também de 
bioclastos de algas vermelhas. A exemplo do cimento $\mathbf{g}$ sugere ambiente de cimentação vadoso.

Com base no ambiente geoquímico interpretado de formação do cimento, se essencialmente vadoso (v) ou com indícios de condições freáticas (f), as petrofácies foram finalmente agrupadas em quatro associações (Quadro 9).

Quadro 9. Sumário de descrição e interpretação das petrofácies de eolianitos. Os termos destacados em negrito referem-se aos aspectos utilizados como critérios para os respectivos códigos de petrofácies.

\begin{tabular}{|c|l|c|}
\hline Petrofácies & \multicolumn{1}{|c|}{ Descrição } & $\begin{array}{c}\text { Associação de } \\
\text { petrofácies }\end{array}$ \\
\hline $\begin{array}{c}\text { Q1(r); Q1(fr-si) } \\
\text { (Figura 7.25) }\end{array}$ & $\begin{array}{l}\text { Arcabouço de granulometria unimodal na fração areia média ou fina, com } \\
\text { selecão por moda boa a moderada, grãos subarredondados a subangulares e } \\
\text { esfericidade alta a mediana, composto principalmente por quartzo } \\
\text { monocristalino e por bioclastos de algas vermelhas, presença de cimentos em } \\
\text { franja semi-isópaca e de revestimento e porosidade de até 22\% }\end{array}$ & $\begin{array}{c}\text { Quartzo arenito } \\
\text { unimodal com presença } \\
\text { de cimentos freáticos: } \\
\text { Q1f }\end{array}$ \\
\hline $\begin{array}{l}\text { Q2(fr-i); Q2(r); Q2 } \\
\text { (fr-si) (Figura 7.26) }\end{array}$ & $\begin{array}{l}\text { segrabaça de granulometria bimodal na fração areia média a grossa, com } \\
\text { subangulares e esfericidade mediana a alta, composto principalmente por } \\
\text { quartzo monocristalino e por bioclastos de algas vermelhas; presença de } \\
\text { cimentos em franja isópaca a semi-isópaca e de revestimento e porosidade de } \\
\text { até 20\%. }\end{array}$ & $\begin{array}{c}\text { Quartzo arenito bimodal } \\
\text { com presença de } \\
\text { cimentos freáticos: } \\
\text { Q2f }\end{array}$ \\
\hline Q1(fr-ai); Q1(sv); \\
Q1(b) (Figura 7.27)
\end{tabular}
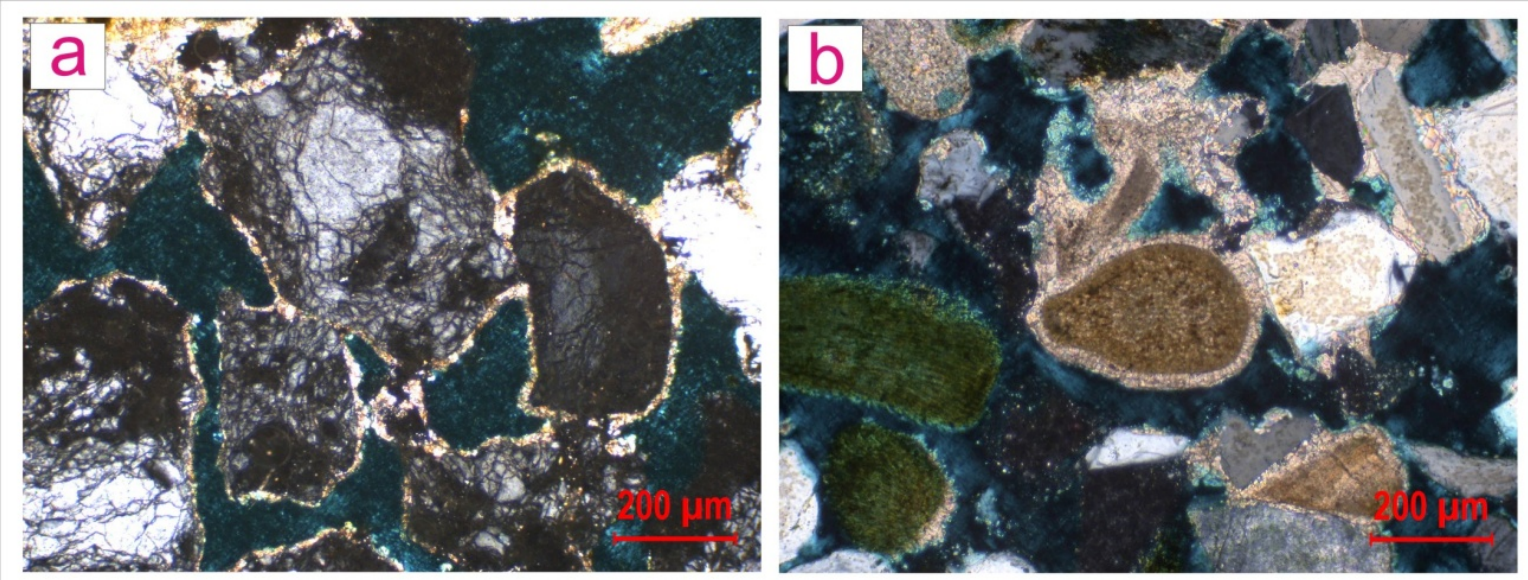

Figura 7.25. Fotomicrografías a nicóis cruzados das petrofácies da associação Q1f, com as subdivisões segundo o cimento presente: a. Q1(r), de revestimento de poro, formado após alguma compactação (EPI37) e b. Q1(fr-si), em franja semi-isópaca, com indícios locais de duas gerações, bordejando clastos de quartzo, feldspato e alga vermelha (EPI34a). 


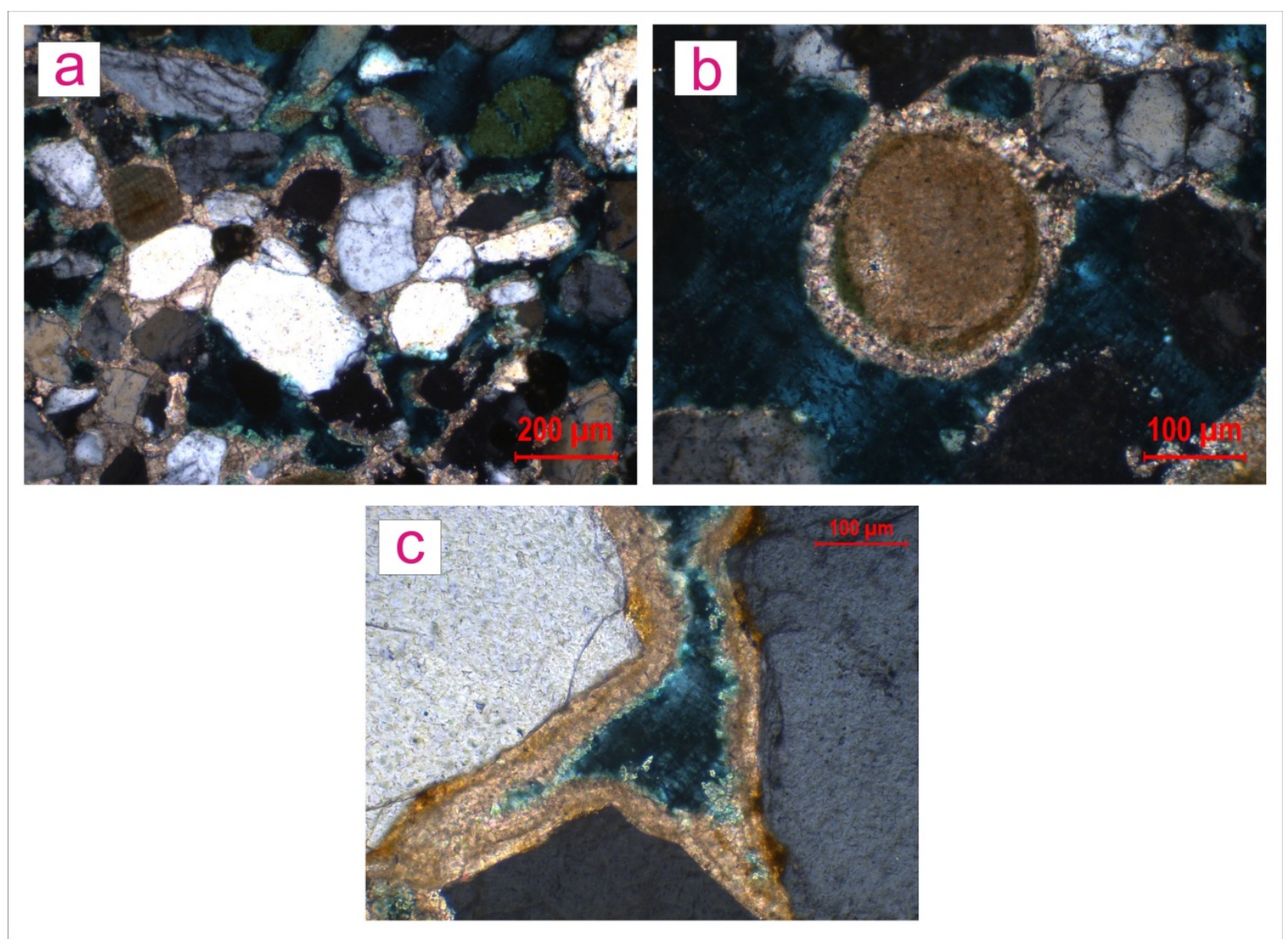

Figura 7.26. Fotomicrografias a nicóis cruzados das petrofácies da associação Q2f com as subdivisões segundo o tipo de cimento presente: a. Q2(r), de revestimento de poro, na amostra EPI35; b. Q2(fr-i), em franja isópaca bordejando bioclasto de alga vermelha com dupla camada de cimento, na amostra ECE34b; e c. Q2f (fr-si), em dupla geração de franja, sendo a primeira isópaca, na amostra ECE51Ec. 

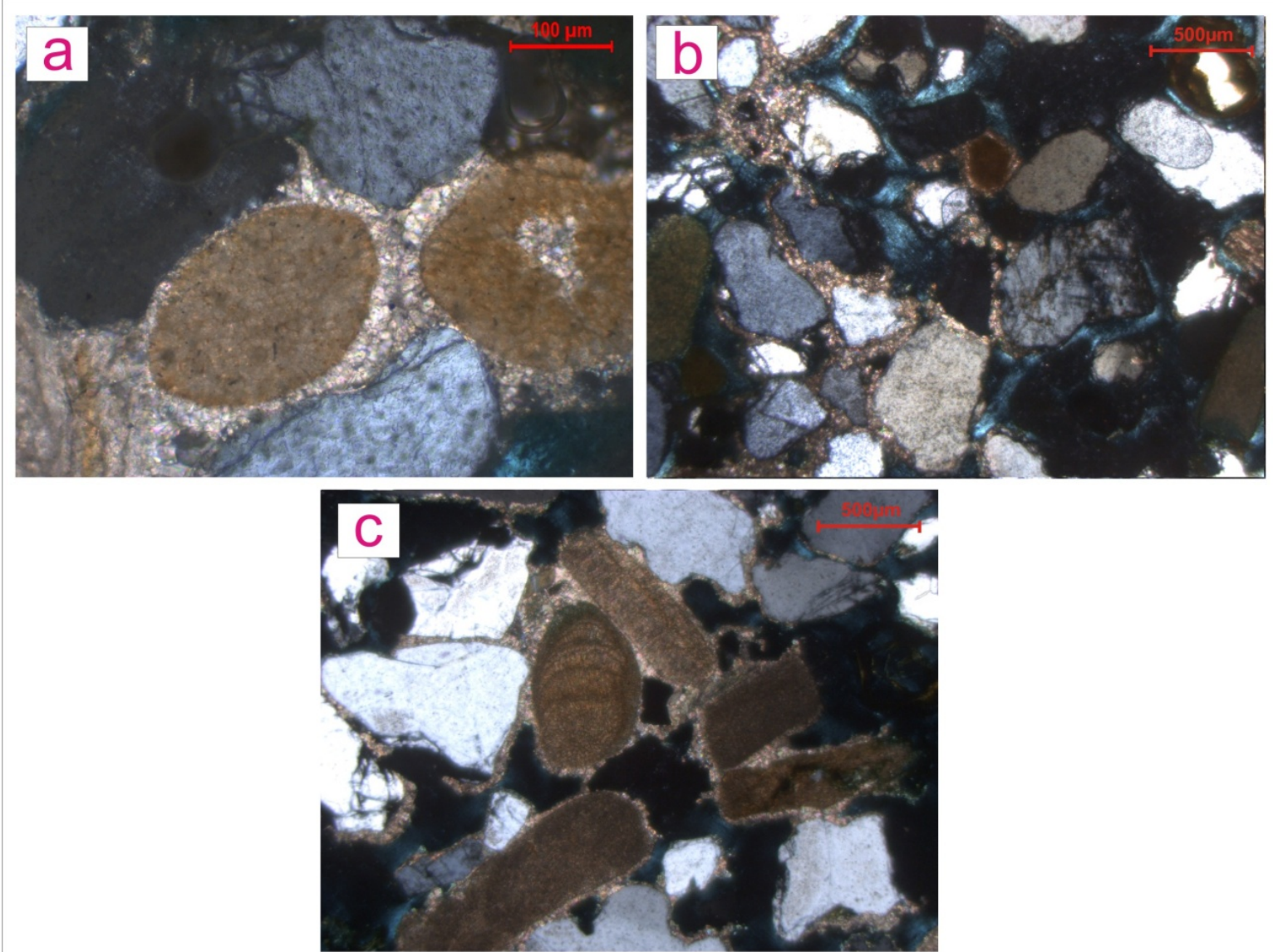

Figura 7.27. Fotomicrografias a nicóis cruzados das petrofácies da associação Q1v, com as subdivisões segundo o cimento dominante: a. Q1(fr-ai), em sutura mediana entre duas franjas anisópacas, na amostra ECE53; b. Q1(sv), com micronódulos subverticais, na amostra ECE46Eb; e c. Q1(b), concentrado junto a aglomeração de bioclastos principalmente de algas vermelhas, na amostra ECE58. 


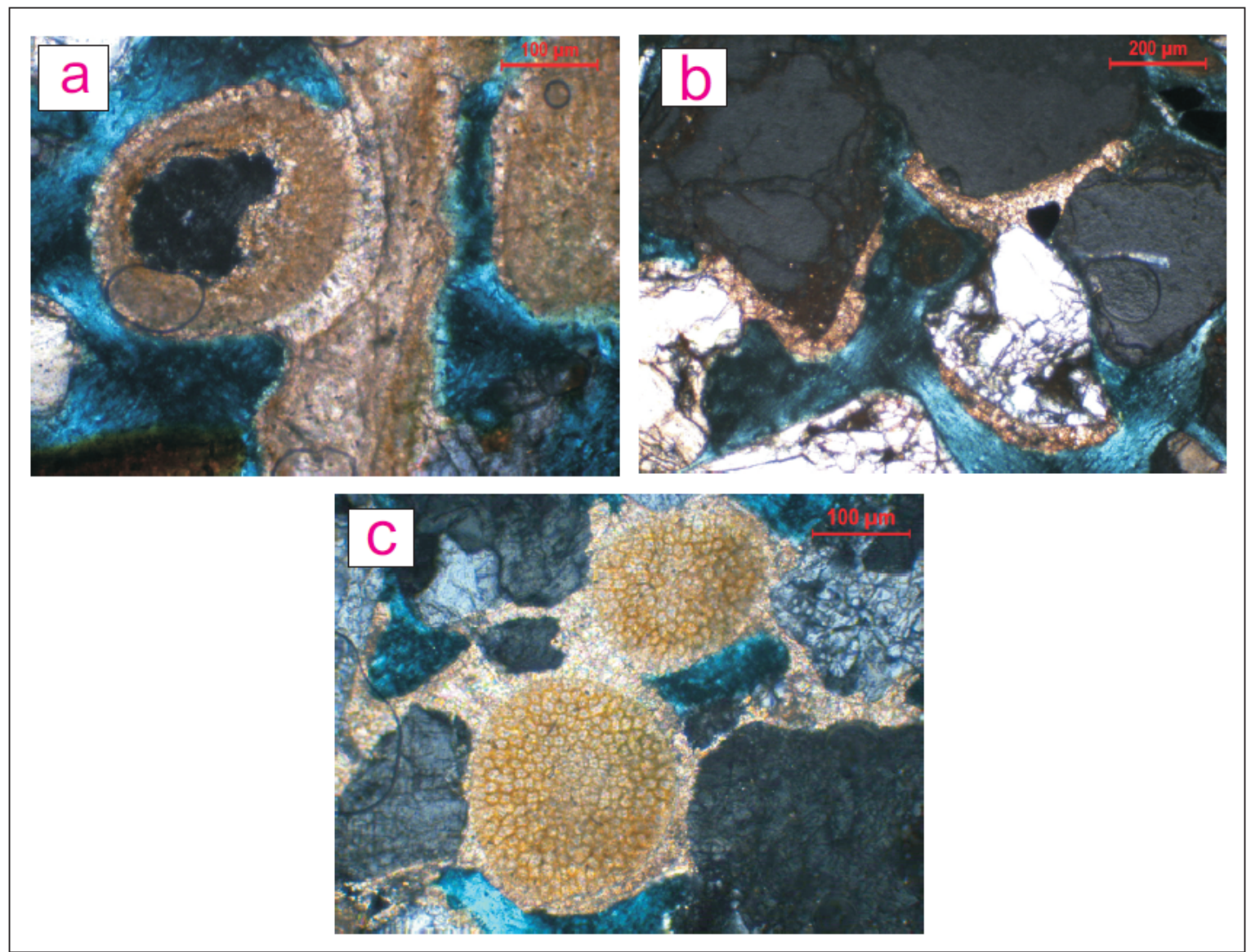

Figura 7.28. Fotomicrografias a nicóis cruzados das petrofácies da associação Q2v, ilustrando a classificação segundo o tipo dominante de cimento carbonático: a. Q2(fr-ai), sutura mediana entre franjas anisópacas adjacentes, na lâmina EPI40; b. Q2(g), gravitacional pendular, indicando a base da lâmina ECE62; c. Q2(m), em menisco, na amostra EPI12.

- Depósitos associados aos eolianitos

$\mathrm{Na}$ distinção de petrofácies dos depósitos associados aos eolianitos (Quadro $10 \mathrm{e}$ Figura 7.27), também se teve em conta a composição mineralógica $(\mathbf{Q})$, o número de modas granulométricas (uni, 1, ou bimodal, 2) e, adicionalmente, a presença de bioclastos (b) ou de vestígios de vida in situ, ou pouco retrabalhados, de gastrópodes (g). Quanto ao cimento, estabeleceram-se as seguintes subdivisões (parêntesis na frente do código): me, para microespato preenchendo bioclastos; of, para material criptocristalino atribuído a matéria orgânica com óxi-hidróxidos de ferro; e cm, para cimento micrítico. 
Quadro 10. Sumário de descrição das petrofácies dos depósitos associados aos eolianitos. Os termos destacados em negrito referem-se aos aspectos utilizados como critérios para os respectivos códigos de fácies.

\begin{tabular}{|c|c|c|}
\hline Petrofácies & Descrição & $\begin{array}{l}\text { Associação / } \\
\text { interpretação } \\
\text { de petrofácies }\end{array}$ \\
\hline $\begin{array}{l}\text { Q1g(of); } \\
\text { Q1g(cm) }\end{array}$ & $\begin{array}{l}\text { Arcabouço de granulometria unimodal na fração areia fina ou média, com } \\
\text { seleção boa, e grãos subarredondados a subangulares de esfericidade alta, } \\
\text { compostos principalmente por quartzo monocristalino e por carapaças de } \\
\text { gastrópodes; cimento micrítico e/ou orgânico-ferruginoso de trama } \\
\text { grumosa ou micropeloidal, com porosidade de até } 10 \%\end{array}$ & $\begin{array}{l}\text { Quartzo arenito } \\
\text { unimodal com } \\
\text { gastrópodes, de } \\
\text { paleossolo: Q1g }\end{array}$ \\
\hline Q2g(me) & $\begin{array}{l}\text { Arcabouço de granulometria bimodal na fração areia fina a grossa, com } \\
\text { seleção pobre a moderada, e grãos subangulares de esfericidade média, } \\
\text { compostos por quartzo mono e policristalino e por carapaças de } \\
\text { gastrópodes; cimento microespático e porosidade de até } 20 \%\end{array}$ & $\begin{array}{l}\text { Rudito de } \\
\text { gastrópodes } \\
\text { preenchido por } \\
\text { quartzo arenito } \\
\text { bimodal: Q2g }\end{array}$ \\
\hline Q2b(cm) & $\begin{array}{c}\text { Arcabouço de granulometria bimodal na fração areia fina a grossa, com } \\
\text { seleção pobre a moderada, e grãos subangulares de esfericidade média, } \\
\text { compostos por quartzo mono e policristalino e por bioclastos; cimento } \\
\text { micrítico e porosidade de até } 20 \%\end{array}$ & $\begin{array}{l}\text { Quartzo arenito } \\
\text { bioclástico } \\
\text { bimodal: } Q 2 b\end{array}$ \\
\hline Q2(cm) & $\begin{array}{l}\text { Arcabouço de granulometria bimodal na fração areia grossa a fina, com } \\
\text { segregação granular, seleção pobre e grãos subarredondados a subangulares } \\
\text { de esfericidade alta a média, compostos principalmente por quartzo } \\
\text { policristalino; cimento micrítico e porosidade de até } 10 \%\end{array}$ & $\begin{array}{l}\text { Quartzo arenito } \\
\text { bimodal: Q2 }\end{array}$ \\
\hline
\end{tabular}

Na petrofácies Q1g, fácies Amg, a presença de trama grumosa ou micropeloidal nos cimentos micrítico e organo-ferruginoso (Figuras 7.29 a e b) aponta para agregação pedogenética, possivelmente sob influência de agentes biológicos, o que reforça a associação desta fácies deposicional com paleossolos, feita no Artigo 1.

$\mathrm{Na}$ fácies Apb (beach-rock), o registro de cimentos em franja anisópaca com formato de pêndulo e menisco (Figura 7.17) indica condições vadosas de cimentação, coerente com a atribuição desta fácies, no Artigo 1, à zona de espraiamento. 

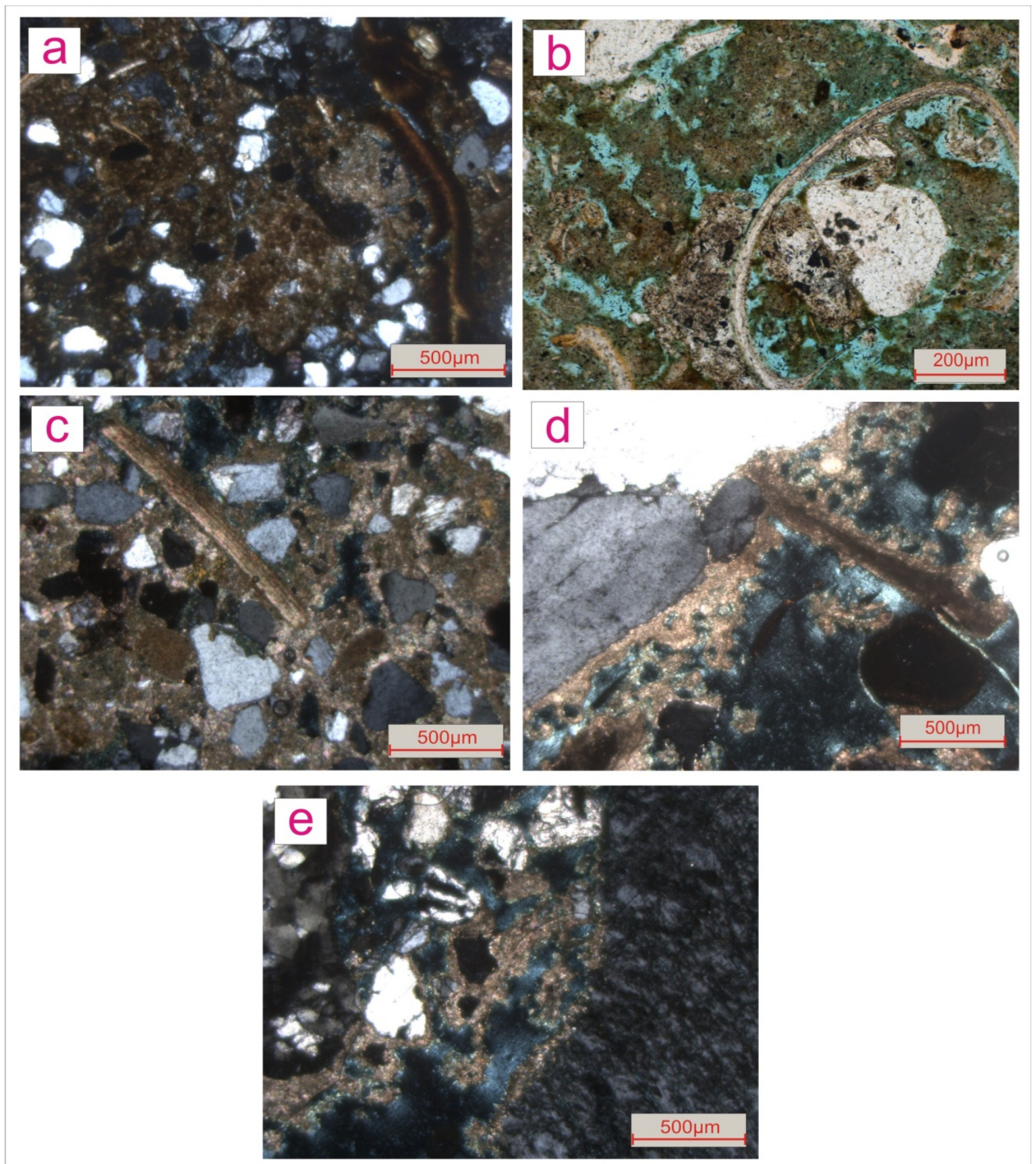

Figura 7.29. Petrofácies dos depósitos associados aos eolianitos: a. Q1g (of), quartzo arenito unimodal com gastrópodes e cimento ferruginoso, na amostra EPI45b; b. Q1g (cm), quartzo arenito unimodal com bioclastos e cimento micrítico grumoso, na amostra EPI45c; c. Q2g (me), quartzo arenito bimodal com cimento microespático e conchas de gastrópode, na amostra ECE49con; d. Q2b (cm), quartzo arenito bimodal com bioclastos e cimento micritico, na amostra ECE51y; e e. Q2 $(\mathrm{cm})$, quartzo arenito bimodal com cimento micrítico na amostra ECE51PB. Fotomicrografia b a nicóis paralelos; demais, a nicóis cruzados. 


\subsubsection{Variação das petrofácies de eolianitos}

A distribuição espacial das associações de petrofácies (Figuras 7.30 e 7.31) não evidencia diferenças entre os setores. Porém, dentro do setor norte (Figura 7.30), a petrofácies Q2v parece concentrar-se preferencialmente na região onde a sedimentação eólica é mais expressiva hoje (cordão de precipitação na borda sul do campo de dunas de Macapá), com maior saturação aparente em areia. Uma possível razão para esta ocorrência preferencial de arenitos bimodais com cimento vadoso na zona com deposição eólica mais espessa é a maior presença, nesta porção do campo de dunas, de faces de avalancha (slipfaces) de flanco de feição eólica (rastros residuais e cordões de precipitação), o que favorece a segregação granular de modas granulométricas, a elevação do depósito a cotas maiores, e, portanto, mais afastadas do freático, e, por consequência, a menor saturação dos poros em água.

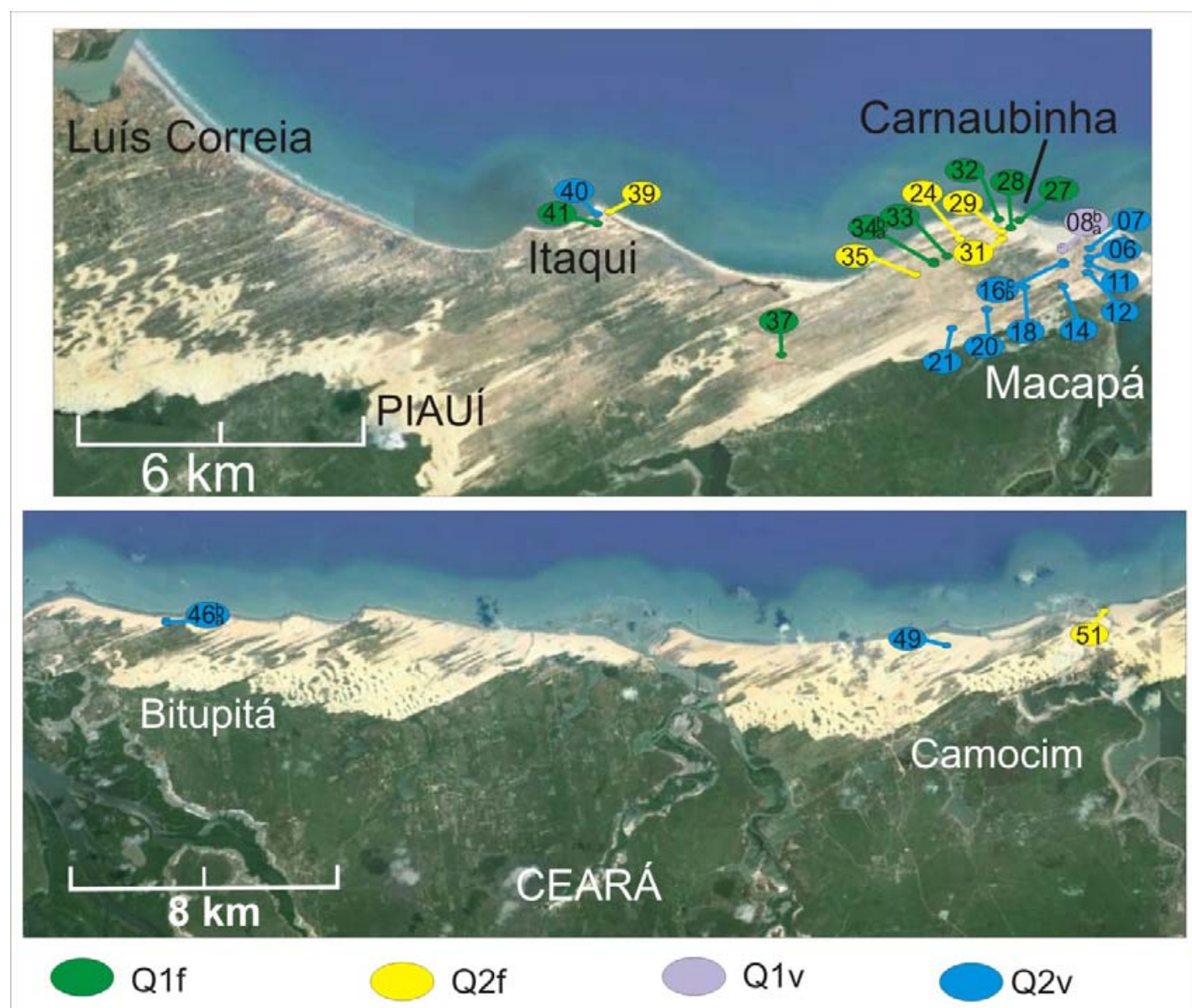

Figura 7.30. Mapas do setor norte com a localização das amostras de petrografia e as associações de petrofácies reconhecidas em cada uma. No Piauí (imagem superior), notar concentração da petrofácies Q2v (bimodal vadosa) na região hoje mais saturada em areia eólica. 


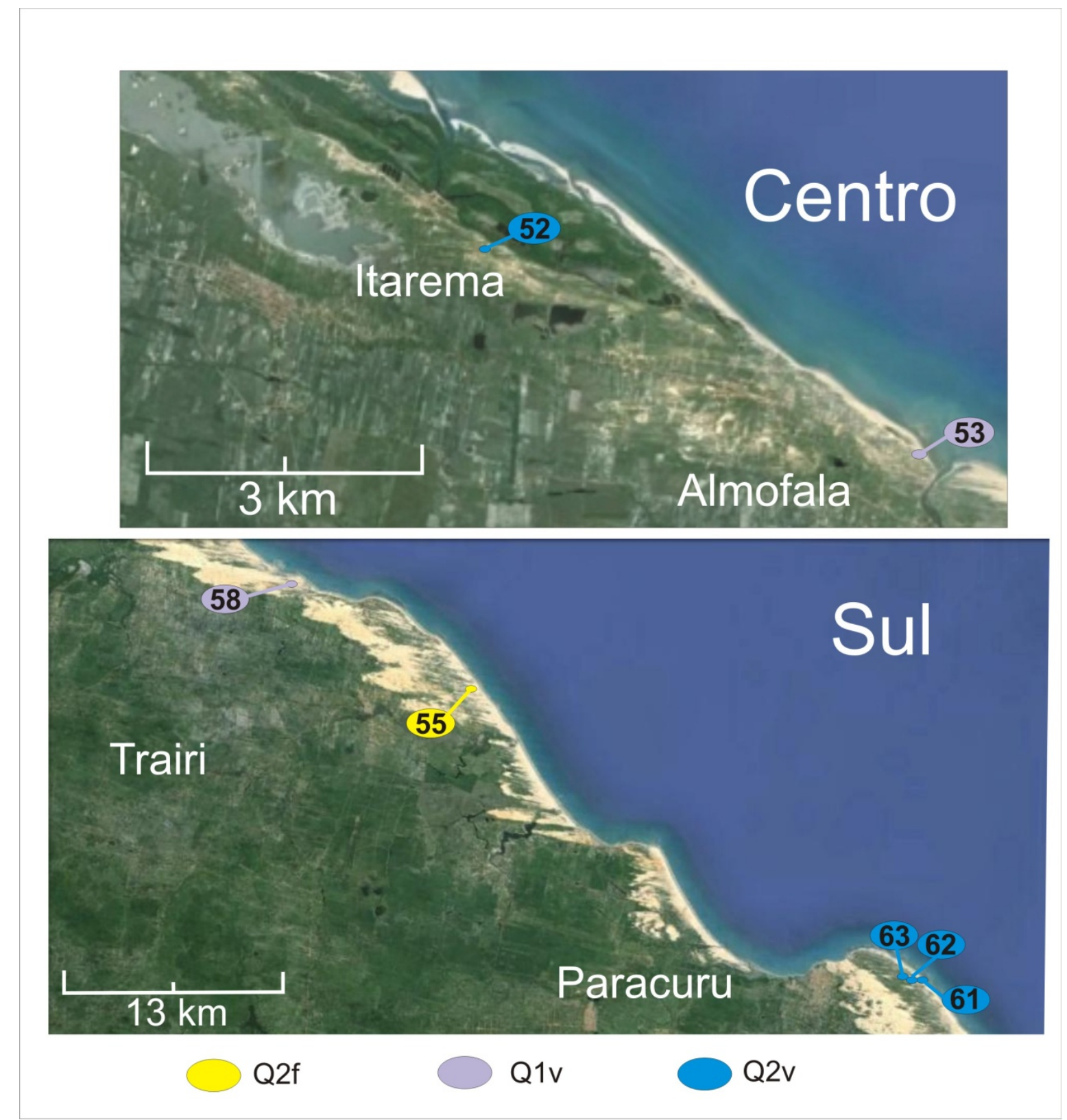

Figura 7.31. Mapas dos setores centro e sul com a localização das amostras de petrografia e as associações de petrofácies reconhecidas em cada uma.

O exame da relação das quatro associações de petrofácies reconhecidas em eolianitos com o teor de carbonato determinado por dissolução ácida (Figura 7.32) e com a porosidade estimada na microscopia (Figura 7.32) permite notar que as petrofácies freáticas apresentam maior teor de carbonato e menor porosidade que as vadosas. 


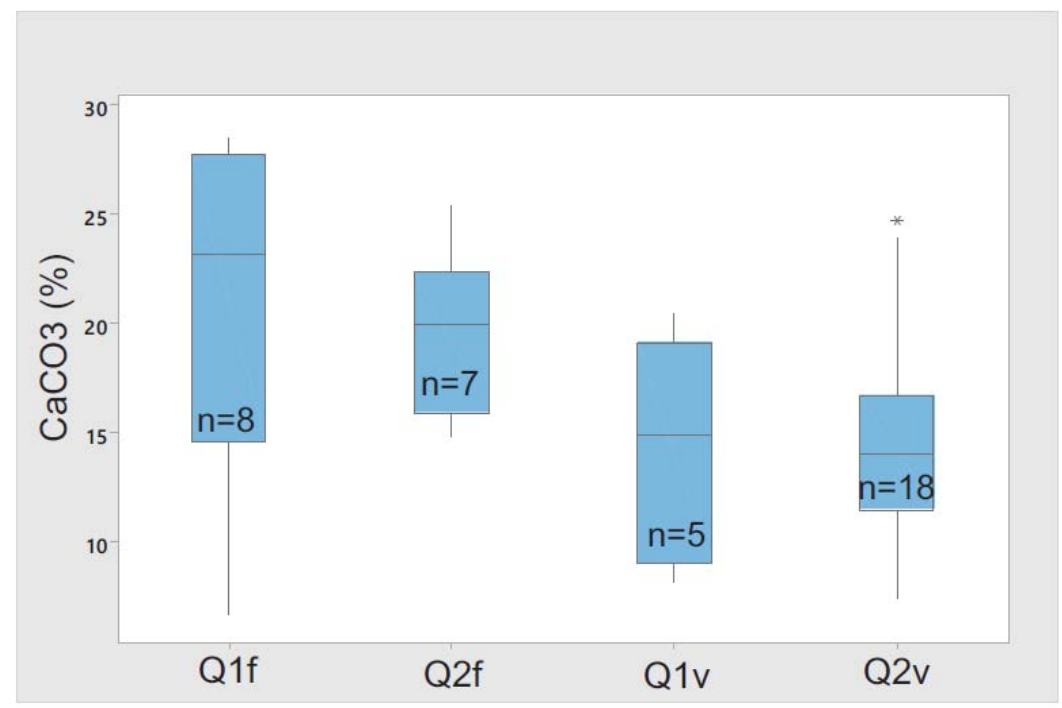

Figura 7.32. Diagrama em caixa para a variação do teor em massa de carbonato, determinado por ataque ácido, por associação de petrofácies, nos eolianitos.

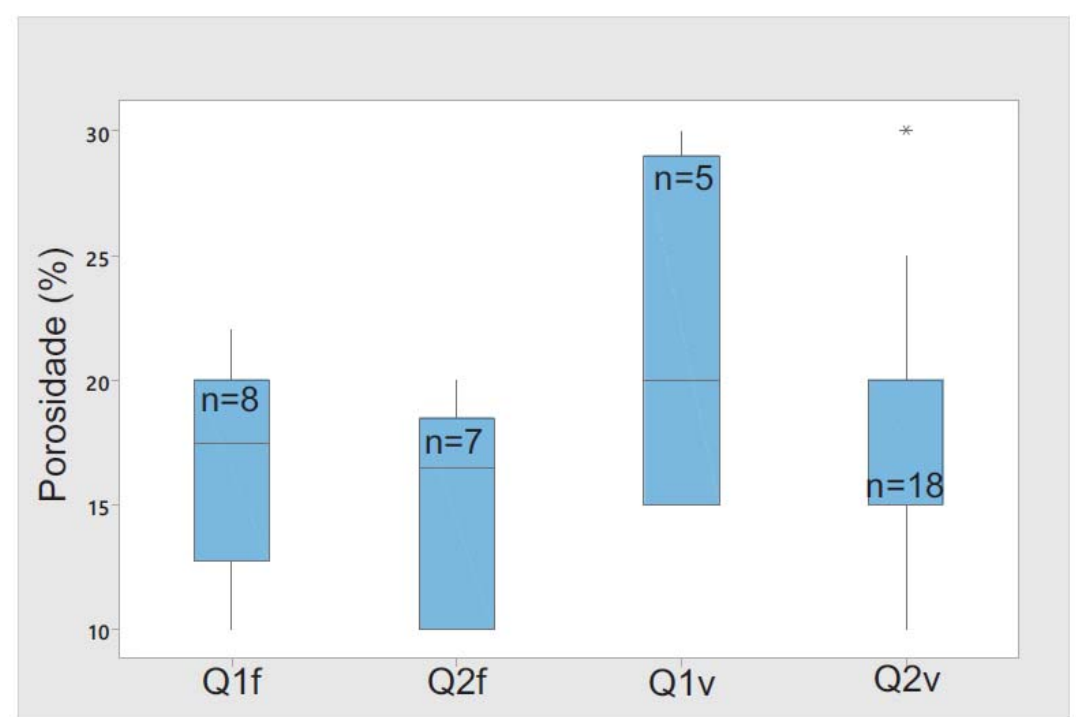

Figura 7.33. Diagrama em caixa para a variação de porosidade por associação de petrofácies, nos eolianitos.

\subsubsection{Características da diagênese dos eolianitos e seus fatores determinantes}

Os eolianitos estudados foram litificados na eodiagênese, zona ou estágio diagenético caracterizado por alterações do depósito em condições de soterramento progressivo raso e precoce, isto é, em intervalo de profundidade e de tempo ainda sob influência das condições geoquímicas da própria sedimentação (Choquette \& Pray 1970; Tucker \& Wright 1990). Este resultado já era esperado face à idade holocênica dos depósitos e à sua formação e manutenção em área de sedimentação eólica, mas com taxa reduzida de acumulação (zona deflacionária). Entre as várias evidências de estágio eodiagenético, podem-se mencionar: 1. a cimentação e litificação restrita às porções superiores do depósito em contato mais direto com o ambiente de sedimentação eólica, 
como evidenciado em campo pela formação de crostas superficiais com cerca de $20 \mathrm{~cm}$ a 2 $m$ de espessura; 2. a presença, em meio a essas crostas, ou na sua transição com a zona inconsolidada subjacente, de lâminas centimétricas a milimétricas menos ou não cimentadas; 3. a falta de compactação mecânica ou química, demonstrada na análise petrográfica pelo empacotamento aberto do arcabouço e pela escassez de contatos intergranulares, os quais, quando presentes, são pontuais; 4. a frequente presença de cimentos envolventes, cuja formação precoce preveniu a aproximação dos grãos; 5. a expressiva porosidade intergranular, remanescente do preenchimento apenas parcial dos poros primários pelo cimento carbonático, o qual, muitas vezes, restringe-se a franjas delgadas (menores que $20 \mu \mathrm{m}$ ); 6. o fato de este cimento carbonático ser principalmente micrítico a microespático, uma indicação de precipitação rápida a partir de soluções supersaturadas e com pouco tempo e/ou profundidade para recristalização espática; 7. a presença marcante de textura micronodular concentrada junto a bioclastos carbonáticos, sugestiva de precipitação localizada a partir dos solutos gerados pela dissolução das bordas destes grãos. Este conjunto de características pode ser usado como guia para identificar produtos e processos eodiagenéticos em eolianitos mais antigos ou mesmo para auxiliar no reconhecimento destes eolianitos no registro estratigráfico, ainda que parte delas (e.g. 5 e 6) possa ser obliterada por eventuais fases diagenéticas superimpostas.

Outras tramas e texturas encontradas no cimento de calcita dos eolianitos estudados em todos os setores (Figuras 7.30 e 7.31) permitem interpretar que esta eodiagênese deu-se predominantemente em condições vadosas. Dentre elas, destacam-se: o cimento distribuído segundo nódulos subverticais, indicativo da presença e circulação capilar ou gravitacional de fluidos (Figura 7.12c); as franjas anisópacas mais espessas junto à borda inferior dos grãos (pendulares), as quais constituem cimento gravitacional indicador de topo e base (geopetal) (Figura 7.12b); e os meniscos, que resultam do aprisionamento da água com solutos, por tensão superficial, nos pontos de maior aproximação entre grãos vizinhos (Figura 7.12a). As evidências de cimentação meteórica vadosa encontram-se em todas as fácies deposicionais e apontam para litificação acima do nível freático. A presença destas evidências mesmo nas fácies ricas em rizonconcreções demonstra que as raízes não eram de plantas de zonas alagadas ou úmidas da planície deflacionária, mas sim do topo, aplainado por deflação, de cristas deposicionais (no caso, os rastros lineares) em meio a essa planície.

Já os indícios de processos de diagênese sob condições freáticas são observados nitidamente na área de Carnaubinha (Figura 7.30), na porção hoje aparentemente menos saturada em areia do setor norte, mas nas outras áreas são escassos e muito localizados. Incluem a calcita, inclusive espática, com trama de preenchimento intersticial ou de revestimento de poro (Figura 7.13b), a qual, em algumas lâminas, parece constituir a segunda geração de cimento e noutras, a primeira. Os indícios da influência esporádica de águas meteóricas freáticas implica momentos de elevação do nível de água subterrânea, o que deve ter permitido a manutenção de fluidos nos poros por tempo mais longo e, por decorrência, a cimentação mais lenta, em cristais maiores. Esta elevação do freático, por sua vez, pode ter pelo menos três tipos de controle: aumento de pluviosidade, ligado seja à sazonalidade anual, a qual é bem marcada na região, seja a períodos mais longos (subdecadais a seculares) de umidificação; flutuações positivas do nível relativo do mar; e 
aumento da frequência e intensidade das inundações, à medida que o campo de dunas se afasta da costa e que a planície deflacionária, por decorrência, se expande. Este último fator, ao contrário dos dois primeiros, possui caráter autogênico, isto é, intrínseco à dinâmica do sistema eólico costeiro analisado. A falta de controle sobre o tempo decorrido entre as gerações de cimento dificulta avaliar qual destes fatores foi o mais determinante da cimentação freática.

As cimentações vadosa e freática dos eolianitos são provavelmente de água doce, haja vista a composição calcítica do cimento verificada por DRX e a não observação, nos mapas de elementos obtidos ao MEV-EED, de concentrações de Mg comparáveis, por exemplo, a das algas vermelhas (Figura 7.14).

As análises petrográficas e de petrofácies sustentam a afirmativa de Carvalho (2003) segundo a qual os eolianitos do Ceará originam-se de cimentação a partir da percolação, no solo, de água contendo carbonato de cálcio derivado dos fragmentos biogênicos. A sazonalidade climática, com estação seca bem determinada, favorece a dissolução dos bioclastos carbonáticos nos momentos de maior pluviosidade, seguida de reprecipitação de carbonato nos momentos mais secos.

Em comparação com outros eolianitos quaternários, como os de Fernando de Noronha (Angulo et al. 2013), por exemplo, a característica mais peculiar da cimentação carbonática eodiagenética nos eolianitos analisados é o seu caráter tênue, o que gera depósitos frágeis e/ou apenas parcialmente litificados. Três aspectos fundamentais determinam esta peculiaridade. $O$ primeiro é a concentração relativamente baixa, no arcabouço, de bioclastos carbonáticos (10 a 15\% em média), o que presumivelmente retarda a velocidade de cimentação. O segundo aspecto é o caráter dominantemente vadoso desta cimentação, o que contribui para cimentos com distribuição heterogênea, não pervasiva. O terceiro é a idade deposicional relativamente jovem dos eolianitos do Piaú e Ceará, na grande maioria dos casos inferior a 4000 anos, portanto com tempo relativo curto de cimentação.

\subsubsection{Os eolianitos e o nível relativo do mar}

Maia et al. (1997) consideram que os fragmentos biogênicos marinhos que constituem os eolianitos teriam sido transportadas da plataforma continental adjacente durante períodos de NRM mais baixo que o atual. No entanto, os teores de bioclastos nesta plataforma são da ordem de 50\% ou mais (Kowsmann \& Costa 1979), muito maiores que os dos eolianitos, pelo que nesta dissertação se sugere, como hipótese alternativa, que a fonte imediata destes bioclastos esteja nas praias, cujos teores de bioclastos são semelhantes aos dos eolianitos. Com base nas idades inferiores a 5000 anos encontradas nas datações realizadas e no comportamento descendente do NRM na região, durante esse período (Caldas et al. 2006; Angulo et al. 2006, Artigo 1), os eolianitos do Piaui e Ceará começaram a formar-se provavelmente sob NRM mais alto que o atual. 
A associação de bioclastos encontrados nos eolianitos do Piauí e do Ceará evidencia predomínio de organismos da Associação Photozoa, de James (1997), representados por algas vermelhas, intraclastos e corais, em relação à Associação Heterozoa, representada por foraminíferos bentônicos (e.g. miliolídeos e numulitídeos), moluscos, cracas e equinodermas. Este resultado contraria a hipótese de Brooke (2001), segundo a qual a distribuição geográfica de eolianitos se correlaciona com a distribuição da Associação Heterozoa. Como o mapa-múndi de ocorrências de eolianito de Brooke (2001) registra número muito maior de casos de média que de baixa latitude, uma possibilidade é que a correlação por ele traçada tenha validade restrita aos eolianitos de latitude média.

\subsection{Conclusões}

Com base nos resultados obtidos e discutidos neste artigo, podem-se listar as seguintes conclusões:

- Os teores de carbonato presentes nos eolianitos e nas praias e dunas atuais são semelhantes entre si (da ordem de 10 a 20\%) e expressivamente mais baixos que os hoje encontrados na plataforma submersa abaixo da isóbata de $10 \mathrm{~m}$ (da ordem de $50 \%$ ou mais). Considerando a idade dominante dos eolianitos (menos de 5000 anos) e o comportamento (declinante) do NRM nesse período, isto indica que a área fonte imediata dos eolianitos foi a praia adjacente e/ou a plataforma interna rasa.

- A granulometria dominante de grãos de quartzo e bioclastos carbonáticos nas praias e dunas atuais varia, na dependência da morfodinâmica costeira, desde areia muito grossa até areia fina, com seleção moderada a pobre. Nos eolianitos, as características granulométricas são semelhantes, com variação segundo a fácies deposicional: tendência para grãos mais finos, com melhor seleção e assimetria mais negativa na fácies de estratificações cruzadas de ângulo alto $\left(\mathbf{A c}_{\mathbf{a}}\right)$ de que nas fácies de ângulo baixo, sem ou com rizoncreções $\left(\mathbf{A c}_{\mathbf{b}}\right.$ e $\left.\mathbf{A c}_{\mathbf{b}} \mathbf{r}_{\mathbf{a}}\right)$.

- A tendência granulométrica regional de afinamento dos eolianitos, com melhora de seleção e assimetria mais negativa, do Ceará para o Piauí, é sugestiva de aumento do grau de transporte sedimentar nesse rumo. Ela pode ter influência da deriva litorânea regional de E (Ceará) para W (Piauí) ou do fato de os eolianitos do Piauí serem mais distais em relação à praia, portanto com maior distância de retrabalhamento eólico.

- Os eolianitos analisados são quartzo arenitos biomicritos a bioespatitos, com menos de $25 \%$ de grãos carbonáticos, estes representados principalmente por algas vermelhas, seguidas de foraminíferos bentônicos (e.g. miliolídeos e numulitídeos), moluscos, cracas, equinodermas, inclusive crinoides e espinhos de equinoides, intraclastos e corais. Esta associação mostra domínio de organismos da Associação Photorozoa da literatura e contrasta com o domínio da Associação Heterozoa encontrado nos eolianitos de média latitude. 
- Petrotrama organizada, com segregação granular quanto a tamanho, forma e composição, e com orientação de grãos alongados, observa-se preferencialmente na fácies $\mathrm{Ac}_{\mathrm{a}}$.

- A formação dos eolianitos na eodiagênese é evidenciada, em campo, pela litificação restrita aos metros superiores dos depósitos e, na petrografia, pelo empacotamento aberto do arcabouço, com contatos intergranulares ausentes a pontuais, e pela presença de cimentos carbonáticos envolventes.

- O fato de este cimento carbonático ser principalmente micrítico ou microespático indica precipitação rápida a partir de soluções super-saturadas e com pouco tempo e/ou profundidade para recristalização espática

- A presença marcante de textura micronodular concentrada junto a bioclastos carbonáticos é sugestiva de precipitação localizada a partir da dissolução das bordas destes grãos, o que reforça a ideia de cimentação rápida.

- As tramas e texturas de cimentação meteórica vadosa incluem micronódulos subverticais ou em torno de lâminas com grãos mais finos ou mais ricas em bioclastos, franjas anisópacas, inclusive geopetais pendulares, e meniscos. Entre as feições de cimentação freática, as quais ocorrem de modo subordinado, destacam-se as franjas isópacas de envolvimento de grão e de revestimento de poros e ocorrem.

- As evidências de diagênese vadosa encontram-se em todas as fácies deposicionais, inclusive naquelas que apresentam rizoconcreções, numa indicação de fitoecologia associada não a zonas alagadas ou úmidas da planície deflacionária (freáticas), mas sim a topos de cristas deposicionais, como rastros lineares residuais e cordões de precipitação.

- A petrografía dos eolianitos permitiu distinguir quatro petrofácies de quartzo-arenitos (Q) segundo o número de modas granulométricas do arcabouço ( 1 ou 2) e as tramas e texturas de cimento, sendo duas delas francamente dominadas por ambientes de cimentação meteórica vadosa (Q1v e Q2v) e duas também influenciadas por cimentação meteórica freática (Q1f e Q2f).

- A distribuição geográfica de ocorrência das petrofácies de eolianitos evidencia maior desenvolvimento das petrofácies com feições freáticas (Q1f e Q2f) no setor norte-Piaú, que é aquele com maior desenvolvimento de planície deflacionária; neste mesmo setor, a petrofácies Q2v associa-se preferencialmente às porções do campo de dunas onde a sedimentação eólica é mais expressiva. Assim, a ocorrência das petrofácies freáticas aparenta favorecimento pelo nível freático raso, este por sua vez favorecido por contextos mais deflacionários.

- Os cimentos freáticos indicam momentos de elevação esporádica do nível de água subterrânea, desencadeados por fatores alogênicos, como o aumento de pluviosidade e flutuações positivas do nível relativo do mar, ou por fatores autogênicos, como o aumento da freqüência e intensidade de inundações, à medida que o campo de dunas se afasta da costa e que a planície de deflação inundável cresce. 
- Tanto a cimentação freática quanto a vadosa são aparentemente de água doce, como sugerido por estudos preliminares de composição da calcita (pobre em magnésio) ao MEV.

- Os eolianitos deste estudo são depósitos frágeis ou apenas parcialmente litificados, o que é determinado pela baixa concentração de bioclastos carbonáticos e pelo fato de a cimentação, dominantemente vadosa, não ser pervasiva e ter acontecido dentro de um tempo relativamente curto (menos de 5000 anos).

- As petrofácies freáticas apresentam maior teor de carbonato e menor porosidade que as petrofácies vadosas. Além disso, o teor de carbonato diminui nas amostras mais antigas, o que sugere eliminação de carbonato por dissolução diagenética ou aumento do aporte de material carbonático, bioclastos por exemplo, através do tempo.

\section{Considerações finais}

O presente estudo dos eolianitos do litoral do Piauí e Ceará permitiu compreender aspectos ligados à sua relação com a morfodinâmica dos sistemas eólicos costeiros, com a composição da plataforma continental rasa que lhes atua como fonte e com o comportamento do NRM e, principalmente, do paleoclima, dentro dos últimos 5700 anos, período em que se deu a sua formação.

Os eolianitos desta região são ricos em grãos terrígenos (cerca de 75 a 90\%); além disso, paleodunas terrígenas sem cimentação carbonática, com aproximadamente a mesma idade, são relatadas na região, pelo menos no Ceará. Com base nisso, pode-se sugerir que os controles para a formação de eolianitos são semelhantes aos dos sistemas eólicos costeiros terrígenos, desde que atendido o requisito da área fonte (plataforma continental interna) de composição carbonática. O litoral estudado é o que melhor atende a este requisito na costa continental brasileira por estar localizado na margem da ZCIT, portanto sob clima quente e relativamente seco (menos de $1200 \mathrm{~mm} / \mathrm{ano}$ ) e, ao mesmo tempo, livre da influência do aporte terrígeno de grandes rios. A combinação de clima tropical de baixa precipitação, com escassez de suprimento terrígeno e com o contexto de NRM alto estabelecido a partir do Holoceno médio, favoreceu a limpidez da água e a proliferação, na plataforma continental, dos organismos da associação Photozoa identificados no arcabouço dos eolianitos, com destaque para algas vermelhas incrustantes e ramificantes.

Outro possível controle na formação dos eolianitos do Piaui e Ceará, este mais local, é o faciológico. Os eolianitos estudados apresentam formas alongadas paralelas ao vento efetivo, mais bem desenvolvidas nos sistemas eólicos costeiros que apresentam zonas deflacionárias. Dentro deste cenário de ocorrência, três evidências principais apontam para sua associação preferencial com rastros lineares residuais: 1. a morfologia, as dimensões e a orientação, semelhantes a dos rastros lineares ativos de mesma região; 2. a 
atitude dos azimutes de mergulho das estratificações cruzadas, em padrão bimodal, com a crista do cordão na bissetriz das duas modas, mesmo padrão registrado em rastros lineares modernos; e 3. o padrão de variação espacial das idades, mais novas à medida que se distancia da praia, o que também coincide com o esperado de rastros lineares residuais formados conforme a migração do campo de dunas. A ausência de eolianitos que registrem, de modo inequívoco, fácies de campos de dunas sensu stricto, como barcanas, barcanoides e lobos deposicionais, sugere que a granulometria mais grossa típica dos depósitos residuais da zona de deflação seja também um fator controlador da abundância de bioclastos carbonáticos e, portanto, da própria formação de eolianitos.

O período de formação de eolianitos identificado neste trabalho coincide com a fase mais árida do Nordeste do Brasil interpretada por Cruz et al. (2009) com base no registro de valores mais altos de $\delta^{18} \mathrm{O}$ em espeleotemas do Rio Grande do Norte (Figura 8.). De acordo com estes autores, a precipitação na Região Nordeste, a exemplo de todo o continente sul-americano, é controlada pela insolação de verão, esta modulada pela ciclicidade orbital de precessão de Milankovitch. O controle, porém, é antifásico em relação ao padrão dominante no continente e bem observado, por exemplo, no leste dos Andes, no Sul-Sudeste do Brasil (Cruz et al. 2005) e no sul da Amazônia. Assim, com o aumento progressivo da insolação de verão austral desde cerca de 8ka A.P., a ZCIT desloca-se para sul no oeste do continente e o Sistema de Monções do Atlântico Sul intensifica-se, levando umidade para os Andes e o Sul-Sudeste do país. A intensificação da atividade convectiva na faixa atravessada pelo SMAS gera, todavia, redução da umidade nas zonas arredores, especialmente no Nordeste do Brasil. Assim, na prática, e especificamente no leste do continente sul-americano, o aumento da insolação do hemisfério sul desloca a zona úmida da ZCIT ligeiramente para norte, em vez de para sul, o que significa redução de umidade e precipitação na Região Nordeste (Figura 8.2). De fato, conforme os dados da curva de insolação de verão austral e dos espeleotemas do Rio Grande do Norte, após um máximo de umidade por volta de 8 ka A.P., o Nordeste se submete a progressiva intensificação da aridez, em tendência oposta a do Sul-Sudeste do país. Na curva dos espeleotemas do Rio Grande do Norte, o valor de $\delta^{18} \mathrm{O}$, considerado indicador de aridez, sofre aumento brusco por volta de 4 ka A.P., que é, justamente, quando se inicia o principal período de formação de eolianitos no Piauí e no Ceará. 


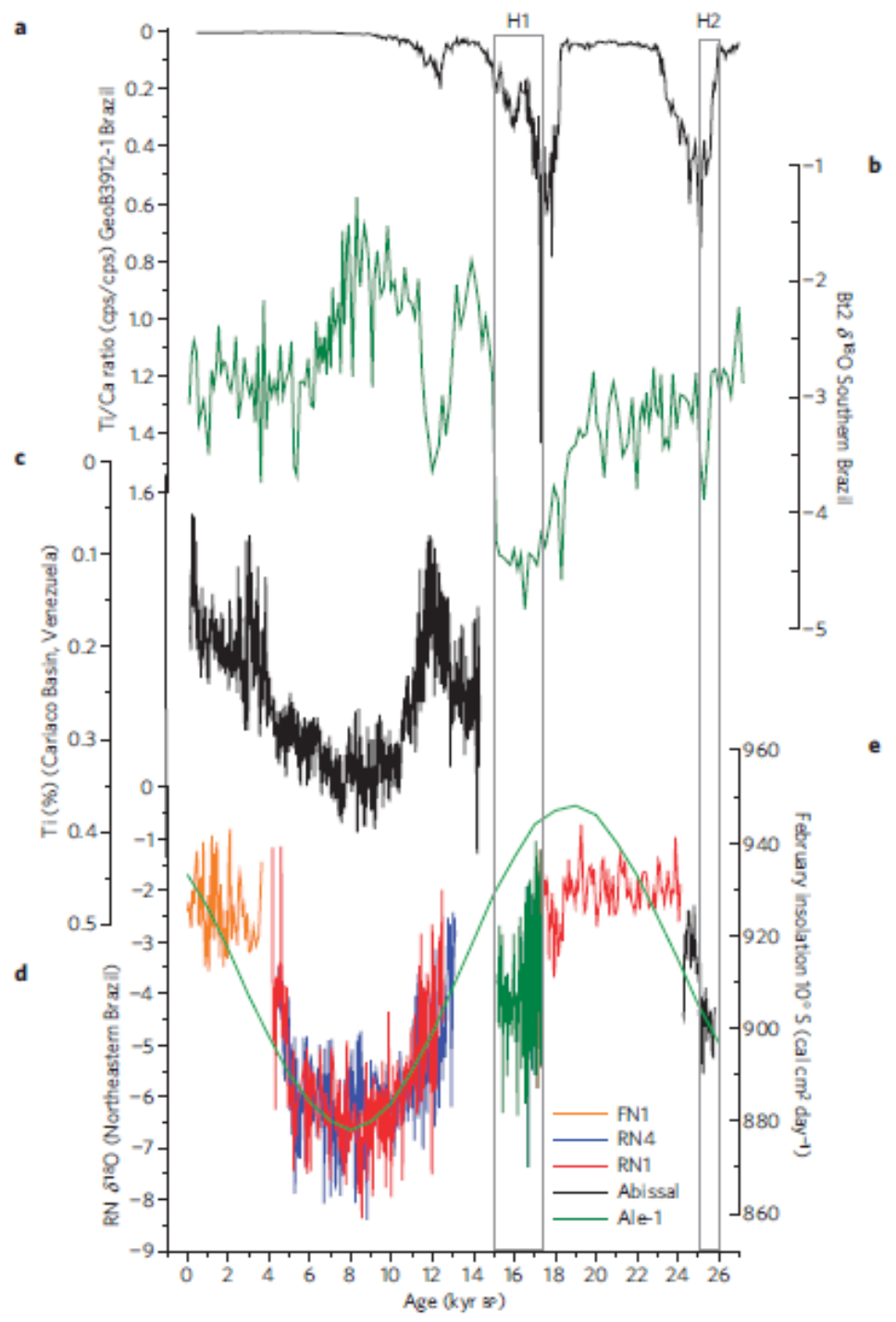

Figura 8.1. Comparação entre indicadores paleoclimáticos: a. índice Ti-Ca do testemunho marinho 3912 , margem continental do Ceará; b. registro de $\delta^{18} \mathrm{O}$ no espeleotema Bt2, caverna Botuverá, Sul do Brasil; c. teor de Ti na Bacia Cariaco, em Venezuela d. registro de $\delta^{18} \mathrm{O}$ no espeleotema RN; e e. insolação de fevereiro a $10^{\circ} \mathrm{S}$. Extraído de Cruz et al. (2009).

O clima regional quente e relativamente mais seco assim interpretado por Cruz et al. (2009) para o Holoceno superior é favorável não só para a redução de suprimento terrígeno à plataforma e a precipitação de cimentos carbonáticos por evaporação nas areias do continente, mas também para a geração de ventos fortes (Mendes \& Giannini 2015), necessários para intensificar as ondulações, erodir os carbonatos submersos da plataforma e transportá-los depois até o campo de dunas do sistema eólico.

Em escala mais local e de mais curta duração, momentos de fortes precipitações e/ou de declínio na intensidade dos ventos podem ter permitido a estabilização das dunas, mediante colonização por vegetação. Estas variações de alta frequência na umidade do clima teriam influenciado a umidade do próprio substrato sedimentar e a posição do nível freático, influindo nas taxas de precipitação química por evaporação, na litificação precoce dos depósitos eólicos e na alternância, vista na petrografia, entre texturas de cimentação 
meteóricas vadosas e meteóricas freáticas. Um ponto a favor desta interpretação de influência de flutuações climáticas na fixação dos eolianitos é o fato de os últimos 4 ka não evidenciarem, na curva dos espeleotemas do Rio Grande do Norte (Figura 8.1), uma redução clara de umidade, mas sim um patamar aproximadamente estável, mas com aumento na frequência e intensidade das flutuações. Este mesmo período coincide com o momento de intensificação do fenômeno El Niño na América do Sul, conforme levantamento de Moy et al. (2002), o que explicaria estas flutuações. Sendo assim, a hipótese de que a estabilização das dunas carbonáticas geradoras dos eolianitos tenha controle alogênico, de fundo climático, embora ainda não bem demonstrada, permanece plausível, e merece atenção nas pesquisas futuras.
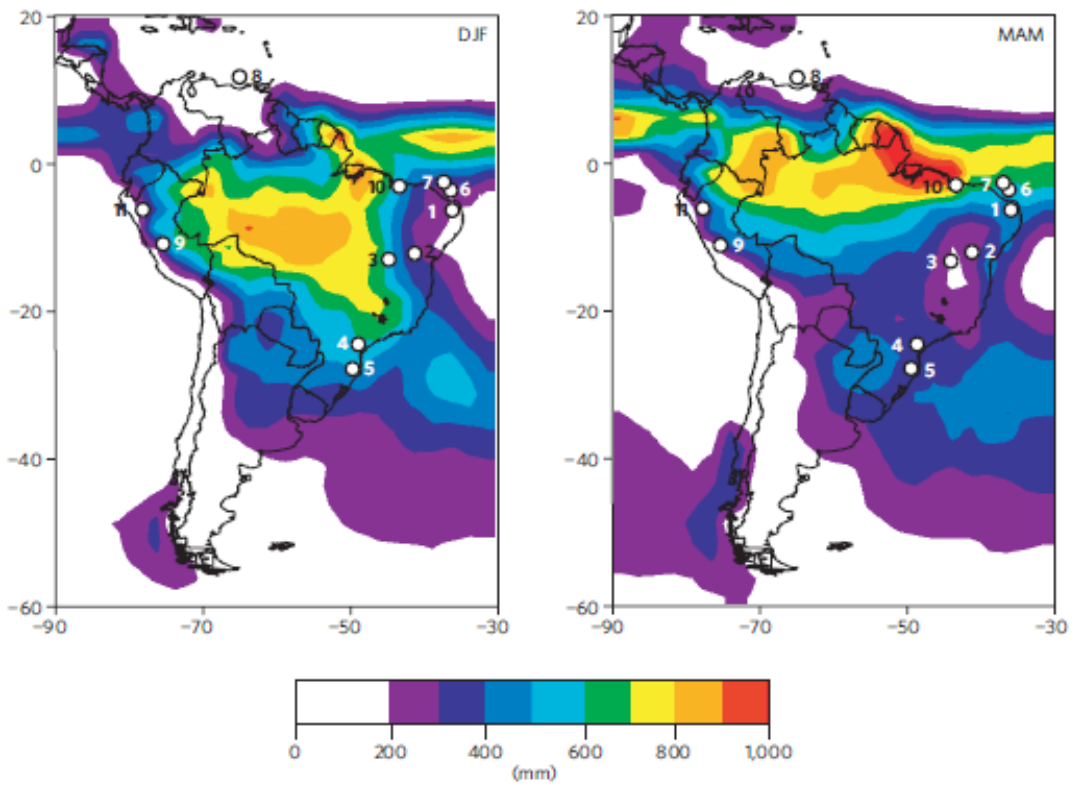

Figura 8.2. Média de longo prazo (1979-2000) da precipitação baseada em dados do Centro de Previsão do Clima combinados com medidas de precipitação total (em $\mathrm{mm}$ ) para dezembro a fevereiro (DJF, esquerda) e março a maio (MAM, direita). A maior parte da precipitação sobre o Brasil ocorre em DJF e está relacionada com o SMAS, enquanto que a parte leste da região Nordeste é relativamente seca. A precipitação no Nordeste do Brasil está associada principalmente com a posição mais meridional da ZCIT in MAM. Os números na figura indicam os locais: 1- Rio Grande do Norte; 2- Toca da Boa Vista; 3- Gruta do Padre; 4- Caverna Santana; 5- Caverna Botuverá; 6- e 7- Testemunhos marinhos GeoB3911-3 e GeoB 3104-1; 8- Bacia Cariaco, Venezuela; 9- Lago Junin, Peru; 10- Lago Caçó; e 11- Cueva del Tigre Perdido. Extraído de Cruz et al. (2009). 


\section{Referências}

AGUIAR, R.B. \& GOMES, J.R.C. 2004. Projeto cadastro de fontes de abastecimento por água subterránea. Diagnóstico do município de Luís Correia. Serviço Geológico do Brasil CPRM.

ANDERTON, R. 1985. Clastic facies models and facies analysis. In: BRENCHLEY, P.J. \& WILLIAMS, B.P.J. eds. Recent Developments and Applied Aspects. Oxford, TheGeol.Soc. Blackwell Scientific Publ. p.31-47.

ANGULO, R.J; LESSA, G.C; SOUZA, M.C. 2006. A critical review of mid- to late-Holocene sealevel fluctuations on the eastern Brazilian coastline. Quaternary Science Reviews, 25: 486506.

ANGULO, R.J; SOUZA, M.C; FERNANDES L.A; DISARÓ, S.T. 2013. Quaternary sea-level changes and aeolianites in the Fernando de Noronha Archipelago, northeastern Brazil. Quaternary International 305 (2013): 15-30

ANGULO, R.J; SOUZA, M.C. 2015. Revisão conceitual de indicadores costeiros de paleoníneis marinho quaternários no Brasil. Quaternary and Environmental Geosciences 05(02) p.01-32.

ARZ, H.W., PATZOLD, J., WEFER, G. 1999. The deglacial history of the western tropical Atlantic as inferred from high resolution stable isotope records off northeastern Brazil. Earth and planetary Sciencie Letters, 167: 105-117.

ARAUJO, M.V. 2011. Modelo Batimétrico da Plataforma Continental Interna de AcaraúCeará-Brasil. Anais XV Simpósio Brasileiro de Sensoriamento Remoto - SBSR, Curitiba, PR, Brasil. INPE p.7682

BAPTISTA, E.M.C. 2010. Estudo Morfosedimentar dos Recifes de Arenito da Zona Litorânea do Estado do Piauí, Brasil. Tese de Doutorado Universidade Federal de Santa Catarina,Centro de Filosofia e Ciências Humanas. Programa de Pós-Graduação em Geografia - Florianópolis, SC, 2010.

BAKER, S., DIZ, P., VAUTRAVERS, M.J., PIKE, J., KNORR, G., HALL, I.R., BROECKER, W.S. 2009. Interhemispheric Atlantic seesaw response during the last deglaciation. Nature, 457 (26): 1097-1103

BALLARINI, M.; WALLINGA, J.; MURRAY, A.S.; VAN HETEREN, S.; OOST, A.P.; BOS, A.J.J.; VAN EIJK, C.W.E. 2003. Optical dating of young coastal dunes on decadal time scale. Quaternary Sciencie Reviews, 22: 1011-1017.

BARBOUTI, A.; RASTIN, B. 1983. A study of the absolute intensity of muons at sea level and under various thicknesses of absorber. Journal of Physics G: Nuclear Physics, 9:1577-1595

BARBOSA, L.M. 1997. Campos de Dunas Costeiras Associados à Sesembocadura do Rio São Francisco (SE/AL). Salvador, Instituto de Geociências da Universidade Federal da Bahia, Tese de Doutoramento (inéd.), $202 \mathrm{p}$. 
BARRETO, A.M.F, SUGUIO, K., BEZERRA, F.H.R., TATUMI, S.H.. YEE, M., GIANNINI, P.C.F. 2004.Geologia e geomorfologia do Quaternário costeiro do Estado do Rio Grande do Norte. São Paulo, Geologia-USP, 4(2), 1-12.

BARRETO, A.M.F.; SUGUIO, K.; BEZERRA, F.H.R.; TATUMI, S.H.; YEE, M.; OLIVEIRA, P.E. 2002a. Datação de dunas costeiras inativas do Estado da Paraíba por métodos de luminescência. In: CONGRESSO BRASILEIRO DE GEOLOGIA, 41, João Pessoa, PB, Anais... João Pessoa, SBG, p. 351.

BERNAT, M; MARTINI L; BITTENCOURT, A.C.S.P.; VILASBOAS G.S.1983. Datation Io/U $\mathrm{du}$ plus haut niveau marin interglaciairesur le côte du Brésil: Utilization du $229^{\mathrm{Th}}$ commetraceur. Comptes Rendus de L'Académie de Sciences de Paris, 296: 197-200.

BITTENCOURT, A.C.S.P.; MARTIN, L.; DOMINGUEZ, J.M.L.; FERREIRA, Y.A. 1982. Dados preliminares sobre a evolução paleogeográfica do Rio São Francisco - SE/AL, durante o Quaternário: influência das variações do nível do mar. In: SIMPÓSIO DO QUATERNÁRIO NO BRASIL, 4, Rio de Janeiro, RJ, 1981. Atas... Rio de Janeiro. p. 49-68.

BROOKE, B. 2001. The distribution of carbonate eolianites. Earth Science Reviews 55 (Ž2001): $135-164$

CALDAS, L.H.O.; STATTEGGER, K.; VITAL, H. 2006. Holocene sea-level history: evidence from coastal sediments of Rio Grande do Norte coast, NE Brazil. Marine Geology, 228: 3953.

CARTER, R.W.G. 1988. Coastal Environments. London, Academic Press, 617p.

CARVALHO, A.M. 2003. Dinâmica Costeira a Atividade entre Cumbuco e Matões- Costa NW do Estado do Ceará. Tese de Doutorado, Salvador, 194p.

CARVALHO, A.M., COUTINHO, P.N. \& MORAIS, J.O. 1994. Caracterização geoambiental e dinâmica costeira da região de Aquiraz na costa leste do Ceará. Revista Geologia UFC7:5568 , Fortaleza.

CARVALHO, A.M., CLAUDINO SALES, V., MAIA, L.P., CASTRO, J.W.A. 2008. Eolianitos de Flecheiras-Mundaú, Costa Noroeste do Estado do Ceará, Brasil. Sitios Geologicos e Paleontologicos do Brasil. 118

CASTRO, J.W.A; RAMOS, R.R.C. 2006. Idade das dunas móveis transversais no segmento entre Macau e Jericoacoara - litoral setentrional do nordeste brasileiro. In: Arquivos do Museu Nacional, Rio de Janeiro,64,(4) p.361-367, out./dez.2006.

CASTRO, J.W.A; GONÇALVES, A. R. \& GURGEL Jr.,J.B., 1998. Os eolianitos da costa oeste do Estado do Ceará. In: CONGRESSO BRASILEIRO DE GEOLOGIA 40, Belo Horizonte MG. Anais SBG, Vol. único, 259p.

CAVALCANTI, I.F.A.; FERREIRA, N.J.; DA SILVA, M.G.A.J.; DIAS, M.A.F.S. 2009. Tempo e Clima no Brasil. São Paulo: Oficina de Textos, 463 p.

CAVAlCANTI, V.M.M. 2011. Plataforma Continental: a Última Fronteira da Mineração Brasileira. Brasília: DNPM, 2011. 
CHAGAS, M.V. \& MORAIS, J.O. 2013. Morfologia de fundo do litoral do Camocim Estado do Ceará. Anais XVI Simpósio Brasileiro de Sensoriamento Remoto - SBSR, Foz do Iguaçu, PR, Brasil. INPE p. 7848.

CHOQUETTE, P.W. \& PRAY, L. 1970. Geologic nomenclature and classifications of porosity in sedimentary carbonates. AAPG Bull., 54:207-205

CLAUDINO SALES, V. 2002. Les littoraux du Ceará: Evolution Géomorfophologique de la Zone Côtière de l'Etat du Ceará, du Long Terme au Court Terme. Thèse de Doctorat, Université Paris-Sorbonne, 523p.

CLAUDINO SALES, V.; PEULVAST, J.P. 2001. Geomorfologia dos campos de dunas do Estado do Ceará. In: VIII SIMPÓSIO DA ABEQUA, Anais... p.273-276, Porto Alegre

CLAUDINO SALES, V.; PEULVAST, J.P. 2002. Dunes generations and ponds on the coast of Ceará, North-East Brazil. In: ALLISON, R. ed. Applied Geomorphology. John Wiley \& Sons, 421-440, London

COOPER, W.S. 1958. The Coastal Sand Dunes of Oregon and Washington. 169p. Tulsa, Okla, Geological Society America (Memoir, 72).

COSTA, M.B.S.F. 2014. Processos Induzidos por Ondas e Marés no Atol das Rocas: Implicações Geomorfológicas e Projeções Futuras. São Paulo, SP, Instituto Oceanográfico, Universidade de São Paulo, Exame de Qualificação (inéd), 40 p.

COUTINHO, P.N.; FRANÇA, A.M.C. \& SUMMERHAYES, C.P. 1976. Sedimentos superficiais da margem continental nordeste brasileira. In: Revista Brasileira de Geociências, 6(2): 71$9=88$, Rio de Janeiro.

CRUZ JR., F.W.; VUILLE, M.; BURNS, S.J.; WANG, X.; CHENG, H.; WERNER, M.; EDWARDS, R.L.; KARMANN, I.; AULER, A.S.; NGUYEN, H. 2009. Orbitally driven east-west antiphasing of South American precipitation. Nature Geoscience, 2: 210-214.

CRUZ JR., F.W.; BURNS, S.J., KARMANN, I., SHARP, W.D., VUILLE, M., CARDOSO, A.O., FERRARI, J.A., DIAS, P.L.S., VIANA JR, O. 2005. Insolation-driven changes in atmospheric circulation over the past 116,000 years in subtropical Brazil. Nature 434: 63-66

CRUZ, Jr. F.W., VUILLE, M., BURNS, S.J., WANG, X., CHENG, H., WERNER, M., EDWARDS, R.L., KARMANN, I., AULER, A.S., NGUYEN, H. 2009. Orbitally driven east-west antiphasing of South American precipitation. Nature Geocience vol. 2 p. 210-214

DOMINGUEZ, J.M.L.; LEÃO, Z.M.A.N.; LYRIO, R.S. 1996. Litoral norte do Estado da Bahia: roteiro da excursão E4. In: CONGRESSO BRASILEIRO DE GEOLOGIA, 37, Salvador, BA. Salvador, SBG, 32p.

DOTT, R.H., Jr. 1964. Wacke, graywacke and matrix - what approach to immature sandstone classification? J.Sedim.Petrol. 34 (3): 625-632

DUNHAM, R.J. 1962. Classification of carbonate rocks according to depositional texture. In: W. E. HAM Ed. Classification of Carbonate Rocks. Am. Ass. Petrol. Geol.1, 108-121

EWING, R.C. \& KOCUREK, G. 2010. Aeolian dune field pattern boundary conditions, Geomorphology, 114, p.175-187. 
FAIRBRIDGE, R.W. \& JOHNSON, D.L. 1978. Eolianite. In: FAIRBRIDGE, R.W. \& BOURGEOIS, J. eds. The Encyclopedia of Sedimentology. Dowden, Hutchinson and Ross, Stroudsburg.

FARIAS, R. F. 2002. A química do tempo: carbono 14. QNESC, v.16.

FOLK, R.L. 1959. Practical petrographic classification of limestones . Amer. Assoc. Petrol. Geol. Bull., 43:1-38.

FOLK, R.L. 1962. Spectral suibdivision of limestone types, Amer. Assoc. Petrol. Geol.Mem. 1, p.62-84

FOLK, R.L. 1965. Some aspects of recristallization in ancient limestones. In:L.C. Pray \& R.C. Murray (eds). Dolomitization and limestone diagenesis; A symposium: 14-48 Soc. Econ.Paleont. and Mineral. Spec. Publi. No13.

FOLK, R.L. 1968. Petrology of sedimentary rocks. Austin, Henphill publ. Co. 170p

FOLK, R. L, 1974. Petrology of Sedimentary Rocks. Austin, Texas : Hemphill Publishing Co.182 p.

FRANCISCO, J.A.S., LIMA, A.A., ARÇARI, D.P. 2001. Datação por carbono -14. UNIFIA. Unifia.edu.br. $11 \mathrm{p}$

FRYBERGER, S.G. \& SCHENK, C. 1988. Pin stripe lamination: a distinctive feature of modern and ancient eolian sediments. Sedimentary Geology, 55: 1-15

GARDNER, D.E. 1955. Beach-sand heavy-mineral deposits of Eastern Austrália. BMR Bulletin, 28: $103 p$

GESICKI, A.L.D. 2007. Evolução Diagenética das Formações Pirambóia e Botucatu (Sistema Aqüifero Guarani) no Estado de São Paulo. Instituto de Geociências, Universidade de São Paulo. Tese de Doutoramento. 175p.

GIANNINI, P.C.F. 1993. Sistemas Deposicionais no Quaternário Costeiro entre Jaguaruna e Imbituba, SC. São Paulo, Instituto de Geociências, Universidade de São Paulo. Tese de Doutoramento (inéd.).2. 2 mapas, 439 p.

GIANNINI, P.C.F. 2007. Sistemas Deposicionais Eólicos no Quaternário Costeiro do Brasil. São Paulo, Inst. Geoc. Univ. S. Paulo. Tese de Livre Docência. 200p.

GIANNINI, P.C.F. \& SANTOS, E.R. 1994. Padrões de variação espacial e temporal na morfologia de dunas de orla costeira no centro-sul catarinense. Bol. Paranaense de Geociências, 42: 7396.

GIANNINI, P.C.F.; SAWAKUCHI, A.O.; MARTINHO, C.T. 2001. A estratigrafia de seqüências na evolução das dunas costeiras de Santa Catarina, sul do Brasil. In: CONGRESSO DO QUATERNÁRIO DOS PAÍSES DE LÍNGUA IBÉRICA, Lisboa, Portugal. Actas...pp.117120.

GIANNINI, P.C.F.; ASSINE, M.L.; BARBOSA, L.; BARRETO, A.M.F.; CARVALHO, A.M.; CLAUDINO-SALES, V.; MAIA, L.P.; MARTINHO, C.T.; PEULVAST, J.P.; SAWAKUCHI, A.O.; TOMAZELLI, L.J. 2005. Dunas e paleodunas eólicas costeiras e 
interiores. In: SOUZA, C.R.G.; SUGUIO, K.; OLIVEIRA, P.E.; OLIVEIRA. A.M. ed. Quaternário do Brasil (capítulo 11). Abequa, ANP, FAPESP, IG, UnG. Ribeirão Preto, SP, Holos Editora, p.235-257.

GIANNINI, P.C.F.; SAWAKUCHI, A.O.; MARTINHO, C.T.; TATUMI, S.H. 2007.Eolian depositional episodes controlled by Late Quaternary relative sea level changes on the Imbituba-Laguna coastal zone (southern Brazil). Marine Geology, 237 (2007): 143-168.

GIANNINI, P.C.F.; SAWAKUCHI, A.O.; MARTINHO, C.T.; GUEDES, C.C.F.; NASCIMENTO, D.R., Jr.; TANAKA, A.P.B.; MENDES, C.C.F.; ZULAR, A.; ANDRADE, H.A.A.; FORNARI, M. 2011. Classificação e dinâmica de feições eólicas costeiras: um modelo sistêmico baseado em exemplos brasileiros. In: CONGRESSO DA ASSOCIAÇÃO BRASILEIRA DE ESTUDOS DO QUATERNÁRIO (ABEQUA), 13, Armação de Búzios, RJ. Anais...meio digital (internet). Armação de Búzios.

GIANNINI P. C. F., SAWAKUCHI, A.O., MENDES, V.R. ZULAR, A. ANDRADE, H.A.A., MARTINHO, C.T., GUEDES, C.C.F. NASCIMENTO, Jr. D.R.TANAKA, A.P.B., FORNAR, M. 2014. Morfodinâmica de sistemas eólicos costeiros: um modelo baseado em exemplos do Holocénico brasileiro e seu potencial interpretativo. Comunicações Geológicas, 101, Especial II, p 681-685

GIANNINI, P.C.F., GUEDES, C.C.F., NASCIMENTO, Jr. D.R. TANAKA, A.P.B. ANGULO, R.J., ASSINE, M.L., SOUZA, M.C. 2008. Sedimentology and morphologic evolution of the Ilha Comprida Barrier System, southern São Paulo coast. Geology of the Brazilian Coastal Barriers, Lecture Notes in Earth Sciences, Springer-Verlag, Heidelberg.

GOLDSMITH, V.1978. Coastal dunes. In: Davis, R.A. (Editor). Coastal Sedimentary Environments. New York: Springer- Verlag, p 171-235

GUEDES, C.C.F. 2012. Cronologia e Sedimentologia dos Depósitos Eólicos Quaternários da Costa Leste Maranhense. São Paulo, Programa de Pós-Graduação em Geoquímica e Geotectônica, IGc- USP.

GUEDES, C.C.F.; GIANNINI, P.C.F.; DEWITT, R.; SAWAKUCHI, A.O.; AGUIAR, V.A.P.; ANGULO, R.J. 2011. O sistema de paleodunas eólicas do nordeste maranhense: datações por LOE-SAR e relações com paleoclima. In: CONGRESSO DA ASSOCIAÇÃO BRASILEIRA DE ESTUDOS DO QUATERNÁRIO (ABEQUA), 13, Armação de Búzios, RJ. Anais... meio digital (internet). Armação de Búzios.

GUEDES, C.C.F., SAWAKUCHI, A.O., GIANNINI, P.C.F., DEWITT, R. , AGUIAR, V.A.P.2013 . Luminescence characteristics of quartz from Brazilian sediments and constraints for OSL dating. Anais da Academia Brasileira de Ciências (Impresso), v. 85, p. 1303-1316.

HEARTY, P.J \& O'LEARY, M.J. 2008. Carbonate and eolianites, quartz, sands, and Quaternary sea level cycle, western Australia: a chronoestratigraphyc approach, Quaternary Geochronology, 3(1-2), 26-55

HESP, P.A. 2000. Coastal Sand Dunes. Form and Function. Massey, Massey University, 28 p. (CDNV Technical Bulletin, 4).

HUNTLEY, D.J., 1985. On the zeroing of the thermoluminiscence of sediments. Physics and Chemistry of Minerals, 12:122-7 
IRION, G., DE MORAIS, J.O., BUNGENSTOCK, F. 2012. Holocene and Pleistocene sea-level indicators at the coast of Jericoacoara, Ceará, NE Brazil. Quaternay Reasearch 77: 251-257

JAMES, N.P. 2007. The cool -water carbonate depositional realm in Cool-water carbonates, Eds. By JAMES N.P. \& CLARKE J.A.D. Soc. Sediment. Geol. Spec. Publ, Vol 56, p 1-22.

KAHN, J.S. 1956. The analysis and distribution of the properties of packing in sand-size sediments: 1. On the measurement of packing in sandstones. Journal of Geology, 64: 385395

KOCUREK, G. \& HAVHOLM, K.G. 1993. Eolian Sequence Stratigraphy - A Conceptual Framework.In: Siliciclastic Sequence Stratigraphy, p.393-409. America Association Petroleum Geologists (Memoir, 58).

KOCUREK, G. \& NIELSON, J. 1986. Conditions fovourable for the fomation of warm climate aeolian sand sheets. Sedimentology, 33 (6): 795-816.

KOWSMANN, R.O. \& COSTA, M.D.A. 1979. Sedimentação Quaternária da Margem Continental Brasileira e das Áreas Oceânicas Adjacentes. Rio de Janeiro: Petrobrás, 55 p. (Série Projeto Remac, 8).

LANCASTER, N. 1995. The Geomorphology of Desert Dunes. London, Routledge, 312p

LEES, B. 2006. Timing and formation of coastal dunes in northern and eastern Australia. Journal of Coastal Research, 22(1): 78-89.

LEHUGEUR, L.G.O. 1995. Aspectos da geologia costeira do Estado do Piauí. In: I Simp. sobre Processos Sedimentares e Problemas Ambientais da Zona Costeira Nordeste do Brasil. Anais...Recife, PE, CNPq / Petrobras / ORSTOM / CPRM / SCTMA/ Facepe. p. 142-143.

McGEE, D., DONOHOE, MARSHALL, J., FERREIRA, D. 2014. Changes in ITCZ location and cross-equatorial heat transport at the Last Glacial Maximum, Heinrich Stadial 1, and the mid-Holocene. Earth and Planetary Science Letters 390 p 69-79

MADSEN, A.T., MURRAY, A.S., ANDERSEN, T.J.; PEJRUP, M., BREUNING-MADSEN, H., 2005. Optically stimulated luminescence dating of young estuarine sediments: a comparison with $210 \mathrm{~Pb}$ and 137Cs dating. Marine Geology, 214: 251-268

MAIA, L.P. 1998. Procesos Costeros y Balance Sedimentario al o Largo de Fortaleza (NEBrasil): Implicaciones para una Gestión Adecuada de la Zona Litoral. Tesis Doctoral, Universitat de Barcelona, Facultat de Geologia, Departement d'Estratigrafia i Paleontologia, $269 \mathrm{p}$

MAIA, L.P., SABADIA, J.A., FREIRE, J.S.S., SERRA, J. 1997. Caracterização geoquímica e diagenética da cimentação carbonática dos beachrocks e eolianitos da região costeira do Ceará. In: XVII Simpósio de Geologia do Nordeste: Boletim... p.177-181

MAIA, L.P.; RODRIGUES, A.C.B.; CASCON, H.M.; BARRETO, A.M.F.; CASTRO, I.B.; TATUMI, H.S.; COSTA, A.A. 1999. Correlação estratigráfica em poços de subsuperfície e dataço de dunas costeiras inativas da região do Cauípe/Pecém - Costa Oeste do Ceará. In: Congresso da Associação Brasileira de Estudos do Quaternário (Abequa), 7, Porto Seguro, BA. Anais...meio digital (cd), Salvador, Abequa. p 65-68 
MAIA, L.P.; GASTÃO, F.G.C.; TATUMI, S.H.; LACERDA, L.D. 2011. A Utilização do Método de Luminescência Opticamente Estimulada para a Datação de Sedimentos de Dunas Costeiras do Nordeste Setentrional do Brasil. Revista Virtual de Quimica, 3(2): 103-115.

MARTINHO, C.T.; GIANNINI, P.C.F.; SAWAKUCHI, A.O.; HESP, P.A. 2006. Morphological and depositional facies of transgressive dune fields in the Imbituba-Jaguaruna region, Santa Catarina State, Southern Brazil. Journal of Coastal Research, SI39: 673-677.

MAUZ, B. \& HOFFMANN, D. 2014. What to do when carbonate replaced water: Carb, the model for estimating the dose rate of carbonate-rich samples. Ancient TL 32: 24-32.

MCKEE, E.D., AND WARD, W.C. 1983. Eolian environment. In SCHOLLE, P. A., BEBOUT, D. G. AND MOORE, C. H. eds. Carbonate Depositional Environments. AAPG Memoir 33:131-170.

MCLAREN, P. \& BOWLES, D. 1985. The effects of sediment transport on grain-size distributions. J. Sediment. Petrol., 55(4): 457-470.

MELO, M.S.; SINFRÔNIO, E.A.S.; GIANNINI, P.C.F.; FACHINI, M.; VICTORINO, M.C. 2004. Manual de Procedimentos Analíticos. São Paulo, Laboratório de Sedimentologia, Instituto de Geociências da USP, Manual Interno (inéd.), 44pp.

MELO, A.B.C.; CAVALCANTI, I.F.A.; SOUZA, P.P. 2009. Zona de convergência Intertropical do Atlântico. In: CAVALCANTI, I.F.A.; FERREIRA, N.J.; SILVA, M.G.A.J. \& SILVA DIAS, M.A.F. 2009. eds. Tempo e Clima no Brasil. São Paulo, Oficina de Textos, p. 25-39.

MENDES, V.R. 2012. Cronologia e Sedimentologia dos Depósitos Eólicos Quaternários da Costa Catarinense, entre Ouvidor e Florianópolis. São Paulo, Programa de Pós-Graduação em Geologia Sedimentar, IGc-USP. Dissertação de Mestrado (inéd.): 97 p.

MENDES, V.R., GIANNINI, P.C.F., GUEDES, C.C.F., DEWITT, R., ANDRADE, H.A.A. 2015 . Central Santa Catarina coastal dunefields chronology and their relation with relative sea level and climatic changes. Brazilian Journal of Geology (online).

MENDES, V.R., GIANNINI, P.C.F. 2015. Coastal dunefields of south Brazil as a record of climatic changes in the South American Monsoon System. Geomorphology 246: 2234.

MILNE, G.A.; LONG, A.J.; BASSETT, S.E. 2005. Modelling Holocene relative sea-level observations from the Caribbean and South America.Quaternary Science Reviews

MOY, C.M., SELTZER, G.O., RODBELL, D. T., ANDERSON, D. M. 2002. Variability of El Nino/Southern Oscillation activity at millennial timescales during the Hohlocene epoch. Nature 420:162-165

MURRAY, A.S., WINTLE, A.G., 2000. Luminescence dating of quartz using an improved single-aliquot regenerative-dose protocol.Radiation Measurement, 32: 57-73.

NEKOLA, J.C. \& COLES, B.F. 2001. Systematics and ecology of Gastrocopta (Gastrocopta) rogersensis (Gastropoda: Pupillidae), a new species from the midwest of the United States of America. The Nautilus, 115: 105-114. 
NEKOLA, J.C. 1999. Terrestrial gastropod richness of carbonate cliff and associated habitats in the Great Lakes region of North America. Malacologia, 41: 231-252.

PETTIJOHN, F.J.; POTTER, P.E.; SIEVER, R.1973. Sand and sandstone. Heidenlberg, Springer Verlag, 618p.

PFALTZGRAFF, P.A.S. 2010. Geodiversidade do Estado do Piauí. In: PFALTZGRAFF, P.A.S.; TORRES, F.S.M; BRANDÃO, R.L. org. Programa Geologia do Brasil, Levantamento da Geodiversidade. Recife: CPRM. 260 p.

PIANCA C., MAZZINI P. L. F., SIEGLE E. 2010. Brazilian offshore wave climate based on NWW3 reanalysis. Brazilian Journal of Oceanography, 58(1): 53-70.

POWERS, M.C. 1953. Comparison chart for visual estimation of roundness. Jour. Sedim. Petrol., 23:117-119

PRESCOTT, J.R.; STEPHAN, L.G. 1982. The contribution of cosmic radiation to the environmental dose for thermoluminiscence dating. In: Proceedings of the Second Specialist Seminar on Thermoluminescence Dating 6, Council of Europe, Strasbourg, p. 17-25

PYE, K. 1983. Formation and history of Queensland coastal dunes. Z. Geomorphol., suppl-bd.45: 175-204.

PYE, K. \& BOWMAN, G.M. 1984. The Holocene Marine Transgression as a Forcing Function on Episodic Dune Activity on the Eastern Australian Coast. In: THOM, B.G. (ed.), Coastal Geomorphology in Australia. Sydney, Academic Press, p. 115-127.

PYE, K. \& TSOAR, H. 1990. Aeolian sand and sand dunes. London, Unwin, 396p.

REIMER PJ, BAILLIE MGL, BARD E, BAYLISS A, BECK JW, BLACKWELL PG, BRONK RAMSEY C, BUCK CE, BURR GS, EDWARDS RL, FRIEDRICH M, GROOTES PM, GUILDERSON TP, HAJDAS I, HEATON TJ, HOGG AG, HUGHEN KA, KAISER KF, KROMER B, McCORMAC G, MANNING SW, REIMER RW, RICHARDS DA, SOUTHON JR, TALAMO S, TURNEY CSM, VAN DER PLICHT J \& WEYHENMEYER CE. 2009. IntCal09 and Marine09 radiocarbon age calibration curves, 0-50,000 years cal BP, Radiocarbon, 51(4): 1111-1150.

ROY, P.S.; COWELL, P.J.; FERLAND, M.A.; THOM, B.G., 1994. Wave-dominated coasts. In: CARTER, R.W.G. \& WOODROFFE, C.D. eds., Coastal Evolution, Late Quaternary Shoreline Morphodynamics. Cambridge, Cambridge University Press, p.121-186.

ROY, P.S. \& THOM, B.G. 1981. Late Quaternary marine deposition in New South Wales and southern Queensland: and evolutionary model. Journal of Geology Society of Australia, 28: 471-89.

SANTOS C.A.R. 2002. Eolianitos de Fernando de Noronha: Processos Deposicionais e PósDeposicionais. Dissertação de Mestrado, Pós-Graduação em Geociências, UFPE. 58p

SAWAKUCHI, A.O. 2003. Sistemas Deposicionais Eólicos na Costa Centro-Sul Catarinense: Relações com o Nivel do Mar. São Paulo, Programa de Pós-Graduação em Geologia Sedimentar, IG-USP, Dissertação de Mestrado, 86 p. (inéd.). 
SAWAKUCHI, A.O. 2006. Morfometria e Simulação Numérica de Campos de Dunas Costeiros Estudo Baseado em Exemplos Brasileiros. São Paulo, Inst. Geoc. Univ. S. Paulo. Tese de Doutorado (inéd.). $316 \mathrm{p}$.

SAWAKUCHI, A.O.; KALCHGRUBER, R.; GIANNINI, P.C.F.; NASCIMENTO JR, D.R.; GUEDES, C.C.F.; UMISEDO, N. 2008. The development of blowouts and foredunes in the Ilha Comprida barrier (Southeastern Brazil): the influence of Late Holocene climate changes on coastal sedimentation. Quaternary Science Reviews, 27: 2076-2090.

SAWAKUCHI, A.O.; GIANNINI, P.C.F.; MARTINHO, C.T.; TANAKA, A.P.B. 2009. Grain size and heavy minerals of the Late Quaternary eolian sediments from the Imbituba-Jaguaruna coast, Southern Brazil: depositional controls linked to relative sea level changes. Sedimentary Geology, 222: 226-240.

SAYLES, R.W., 1931. Bermuda during the ice age. Proceedings of the American Academy of Arts and Science, 66(1):381-468.

Suguio, K., ANGUlO, R.J., CARVAlho, A.M., CORRÊA, I.C.S., TOMAZELLI, L.J. VILWOCK, J.A., VITAL, H. 2005. Paleoníveis do mar e paleolinhas de costa. In: SOUZA, C.R.G., SUGUIO, K., OLIVEIRA, A.M.S., OLIVEIRA, P.E. (orgs). Quaternário do Brasil. Ribeirão Preto: ABEQUA / Holos Editora, 382p.

THOM, B.G.; BOWMAN, G.M.; ROY, P.S. 1981.Late Quaternary evolution of coastal sand barriers, Port Stephens-Myall lakes area, central N.S.W. Autralia. Quaternary Research, 15: 345-364.

TOMAZELLI, L.J. 1990. Contribuição ao Estudo dos Sistemas Deposicionais Holocênicos do Nordeste da Província Costeira do Rio Grande do Sul, com Ênfase no Sistema Eólico. Porto Alegre, Universidade Federal Rio Grande do Sul. Tese de Douroramento. (inéd). 270p.

TSOAR, H; LEVIN, N; PORAT, N; MAIA, L.P; HERMANN, H.J; TATUMI, S.H; SALES, V.C. 2009. The effect of climate change on the mobility and stability of coastal sand dunes in Ceará State (NE Brazil). Journal Quaternary Research, 71 (2009): 217-226.

TUCKER, M. E. \& WRIGHT V.P. 1990. Carbonate Sedimentology. Blackwell Scientific Publications, Oxford, $479 \mathrm{p}$.

UVO, C. B. 1989. A Zona de Convergência Intertropical (ZCIT) e sua Relação com a Precipitação na Região Norte do Nordeste Brasileiro. 88 p. Dissertação (Mestrado em Meteorologia) Instituto Nacional de Pesquisas Espaciais, São José dos Campos.

VALENÇA, M.L.M., NEUMANN, V.H., MENOR, E.A.\& SANTOS, C.E.R.R. 2005. Eolianitos de Fernando de Noronha: uma análise integrada de estudos petrográficos e geoquímicos. 10 Congresso Brasileiro da ABEQUA, Resumos, p 37-39, Guarapari, ES, Brasil.

VASCONCELOS, D.L., SILVA FILHO, W.F.,BEZERRA, F.H.R., BOSKI, T., LIMA-FILHO, F.P.,MESQUITA, A.F.2. 2014. Indicadores do nível relativo do mar e evolução costeira durante o Holoceno tardio na costa do Ceará, Brasil. in: 47 Congresso Brasileiro de Geologia, Salvador, BA

VITAL, H., SILVEIRA, I.M da., AMARO, V.E. 2005. Carta sedimentológica da plataforma continental brasileira-b Área Guamaré a Macau (NE Brasil), utilizando intergração da dados geológicos e sensoriamento remoto. Revista Brasileira de Geofísica 23: 233-241 
WALKER, R.G. 1976. Facies and facies models. General introduction. In: WALKER, R.G. ed. Facies Models. Toronto, Geosc, Canada, 1979, p. 17. (Reprint Series, 1).

WALKER, R.G.1980. Fácies and fácies models. General introduction. In: R.G. Walker (ed.) Facies Models, Geological Association of Canada, p1-7.

WELDEAB, S., SCHNEIDER, R.R., KOLLIING, M.2006. Deglacial sea surface temperature and salinity increase in the western tropical Atlantic in synchrony with high latitude climate instabilities. Earth and Planetary Sciencie Letters, 241: 699-706.

WENTWORTH, C.K. 1922. A scale of grade and class term for clastic sediments. Jour, Sed. Petrol., 30: 377-392

WINTLE, A.G. 2008. Luminescence dating: where it has been and where it is going. Boreas, 37: 471-482.

WINTLE, A.G., MURRAY, A.S., 2006. A review of quartz optically stimulated luminescence characteristics and their relevance in single-aliquot regeneration dating protocols. Radiation Measurements 41, 369-391.

ZULAR, A.; SAWAKUCHI, A.O.; GUEDES, C.C.F.; MENDES, V.R.; NASCIMENTO, D.R., Jr.; GIANNINI, P.C.F.; AGUIAR, V.A.P., DEWITT, R. 2012. Late Holocene intensification of colds fronts in southern Brazil as indicated by dune development and provenance changes in the São Francisco do Sul coastal barrier. Marine Geology, 335: 64-77.

Outras referências tomadas da internet:

GOOGLE EARTH [http://www.google.com/earth/]. Última consulta em 21-09-2015

GWEATHER: [http://www.gweather.org/]. Última consulta em 21-09-2015

TIMELAPSE [http://world.time.com/timelapse/?hpt=hp_mid]. Última consulta em 28-062015 